\title{
تعدد العلل وأثره عند الأصوليين "دراسة أصولية تطبيقية"
}

\author{
الدكتــــور \\ مجدي محمد عبد الرحمز منصور الرحور \\ مقرسر أهول الفقه بكلية اللراسات الإسلإمية والهربية هين \\ للبنير بلسوقة - جامعة الأزهر
}


$(\operatorname{AV})^{\prime}$

تعدد العلل وأثره عند الأصولييي "دراسة أصولية تطبيقية"

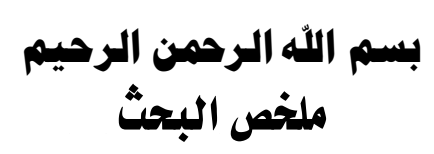

يهدف هذا البحث إلى بيان مسألة مهمة و دقيقة من مسائل العلة ترتبب عليها الخلاف في كثير من المسائل الأصولية، وهى مسألة : تعـدد العلل أو التعليل بعلتين فأكثر، وهي من المسائل الشائكة والمهمة وكثر فيها كـلام الأصسوليين بين مجيز لها ومانع وترتب عليها خلاف كثير في مسائل أصولية متعددة.

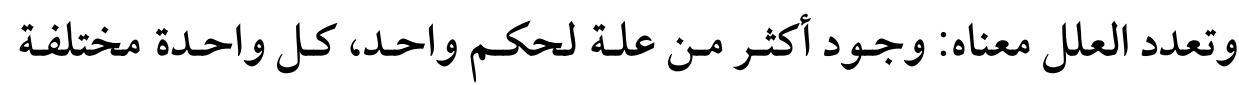
ومستقلة بذاتها لا تعلق لها بغيرها. و منهجي في هذا البحث هو الاستقر اء والتبع للموضوع من خـلال المراجـع والمصادر الأصولية الأصيلة المتعلقة بالموضوع.

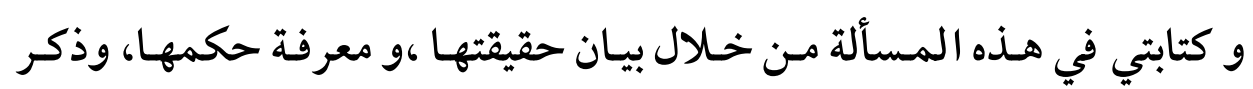
مسائل متعلقة بها، وأثرها عند الأصوليين. و قد اشتمل هذا البحث على مقدمة، وتمهيد ،وأربعـة مباحـث ،وخاتمـة ، أمـا

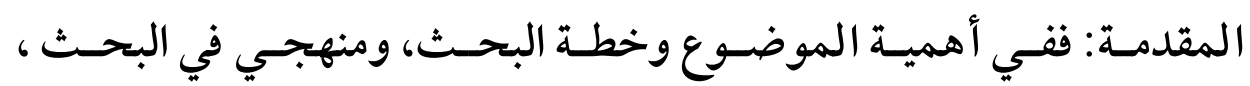

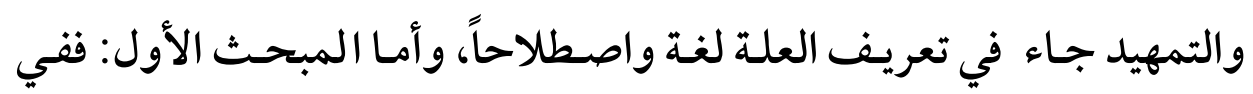
المر اد بتعدد العلل، والفرق بينها وبين العلة المركبة ، وحكـم التعليل بالعلة

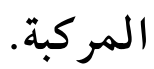

و أما المبحث الثاني: فيشتمل على حكم تعـدد العلل، و مـذاهب العلماء في

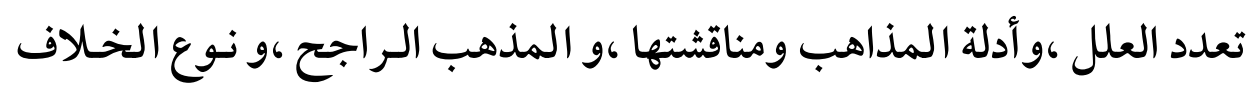

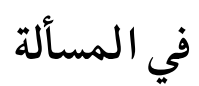


(AvV)

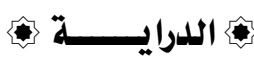

وأما المبحث الثالث: في بيان مسائل ترتبت على جواز تعدد العلل.

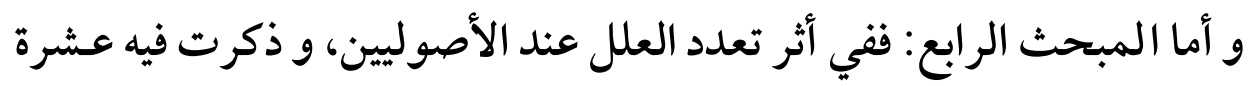
مسائل. ثـم خلـصت الدراسـة والبحــث إلى نتـائج كثيرة منهـا : جـواز تعـدد العلـل

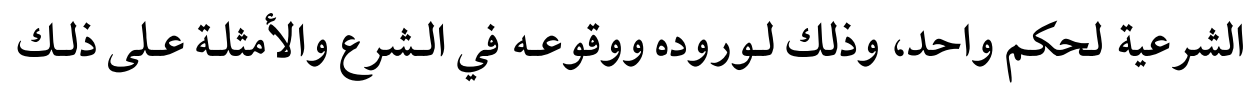

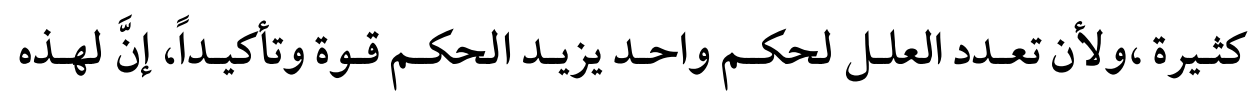
المسالة أثر كبير في كثير من المسائل الأصولية المهمة في باب القياس.

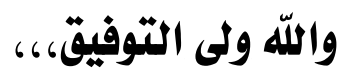


$(\Lambda \vee \wedge)$

تعدد العلل وأثره عند الأصولييي "دراسة أصولية تطبيقية"

\section{المقدهة}

الحمد لله رب العالمين، الملك الحق المبين، والصلاة والسلام على خـاتم

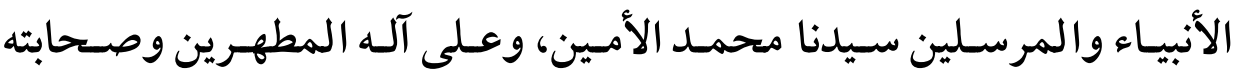

$$
\text { الطيبين، وكل من آمن به وأحبه واتبع هداه إلى يوم الدين. }
$$

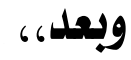

فإنَّ القياس من أهم موضوعات علـم أصـول الفقـه و مباحثـه، لمـا لـه مـن دور

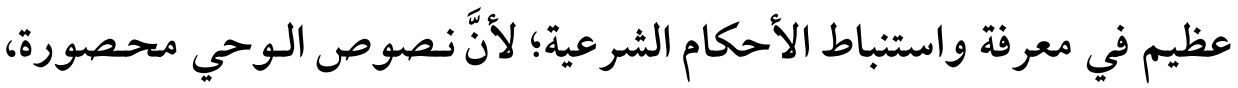

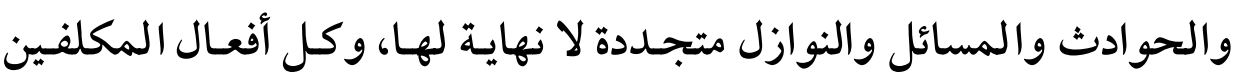

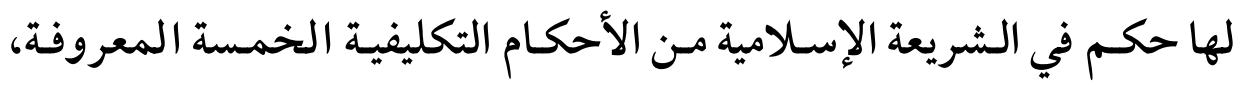

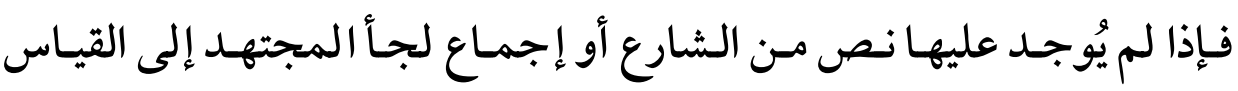
بضوابطه و شروطه التي ذكرها الأصوليون، ولهذا كـان القياس الأصل الرابع من أصول التشريع الإسلامي بعـد الكتاب والسنة والإجماع، وقد تضافرت ودلت الأدلة الشرعية على العمل والاحتجـاج بـه، فهو أصل الر أي وينبوع الفقه، ومنه تتشعب الفروع وعلم الخلاف، وبـه تعلـم الأحكام والوقائع التي

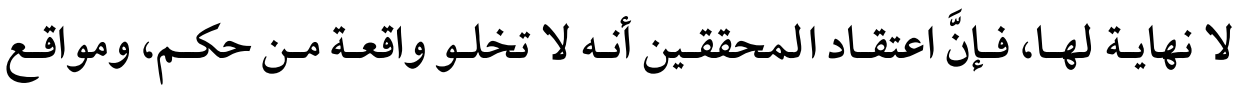
النصوص والإجماع محصورة').

(1) انظر : نشر البنود شرح مراقي السعود لعبد الله بـن إبراهيم العلدوي الشنقيطي / / ـ • ا ، الناشر : مطبعة فضالة بالمغرب. 
و من أركان القياس العلة، بل هي أهم وأعظم ركن فيه، فهي أسـاس القياس وقلبه، وعلى أساس معر فتها في الأصل والتحقق مـن وجودهـا في الفرع يـم القياس ،ويأخذ الفرع حكم الأصل إذا تمت أركان القياس و شروطه.

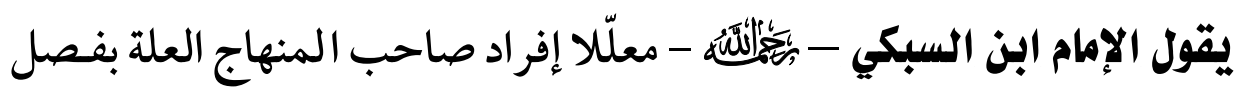
مقدم على باقي أركان القياس:" إنـما أفـرد بيـان العلة بفـصل مقدـدم عـلى بيـان

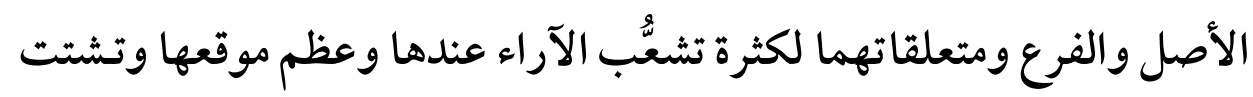

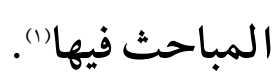
هذا: ومن مسائل العلة الدقيقة والتي كثر الكلام فيها وترتبب عليها الخـلاف

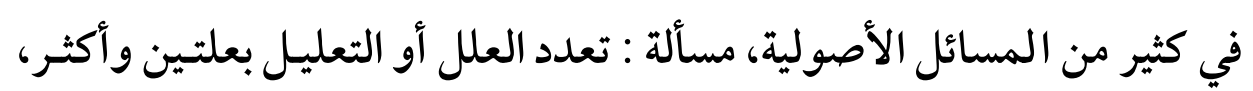

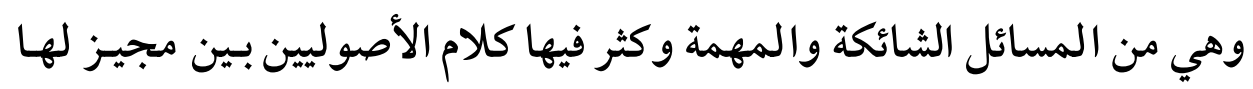
ومانع ، وترجع أهمية هذه المسألة إلى وجود الخلاف في كثير مـن المسائل ولئل الأصولية بسببها كما سيأتي إن شاء الله تعالى.

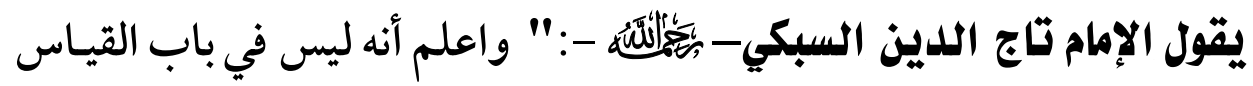
أشكل من الكلام على التعليل بعلتين، ونحـن نتوسط في إيـراده، فلا نسهب في بـ

(1) الإبهاج في شرح المنهاج على منهاج الوصول إلى علم الأصول للبيضاوي لعلي

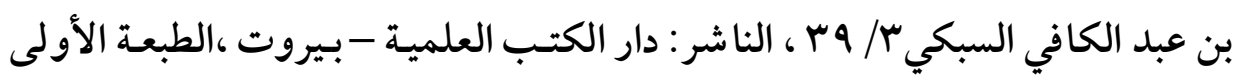


$(\Lambda \Lambda \cdot)$ تعدد العلل وأثره عند الأصولييي "دراسة أصولية تطبيقية"

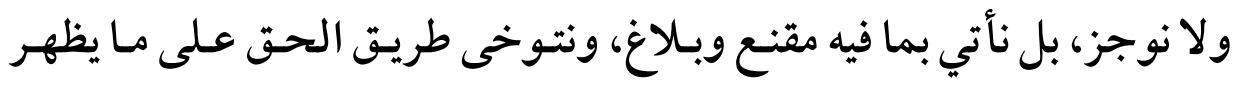

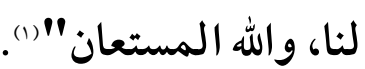
هـذا: وسـاتتكلم -إن شـاء الله تعـالى -عـن هـذه المـسألة مـن خـالال معرفـة حكمها، وبيان وذكر مسائل متعلقة بها، وأثرها عند الأصوليين.

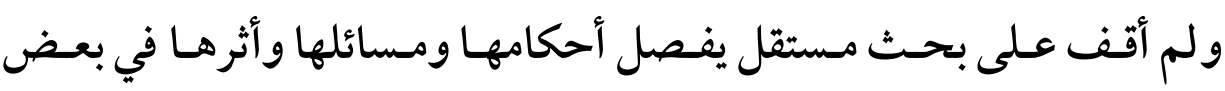
المسائل الأصولية، ولذلك تتبعت كتب الأصـوليين وبحثت عنها في مظانها حتى وفقني الله تعالى إلى هـذه الدراسـة وهـذا البحـث، والله المستعان وعليه التكلان.

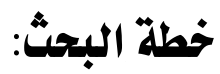
قمت بعون الله وتوفيقه بتقسيم البحـث إلى مقدمة و تمهيد وأربعـة مباحـث و

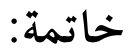
أما المقدمة ففي أهمية الموضوع، وخطة البحث ومنهجي في البحث، . وأما التمهيد ففي: تعريف العلة لغة واصطلاحاً.

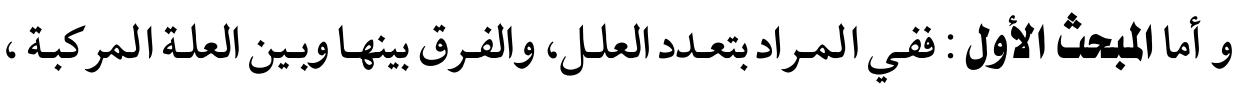

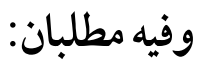
المطلب الأول: المراد بتعدد العلل، والفرق بينها وبين العلة المركبة. المطلب الثاني: حكم التعليل بالعلة المر كبة.

(1) رفع الحاجب عن مختصر ابن الحاجب لتاج الدين عبد الوهـاب بـن تقي الدين

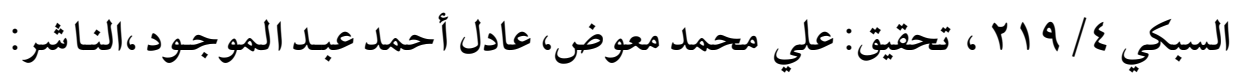

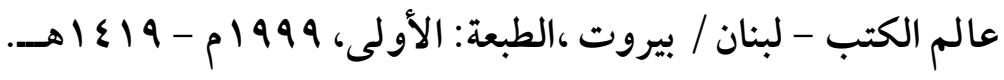


(A^I)

وأما المبحث الثاني: ففي حكم تعدد العلل، وفيه ثلاثة مطالب:

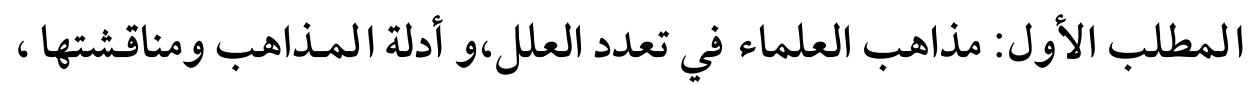

$$
\begin{aligned}
& \text { المذهب الراجح } \\
& \text { ونوع الخلاف في المسألة. }
\end{aligned}
$$

المطلب الثاني: العلل المتعددة كل واحدة علة مستقلة لا جزء علة.

$$
\text { المطلب الثالث: نوع الحكم الثابت بعلتين أو أكثر . }
$$

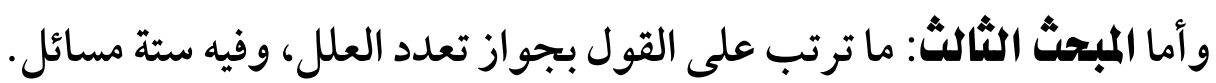

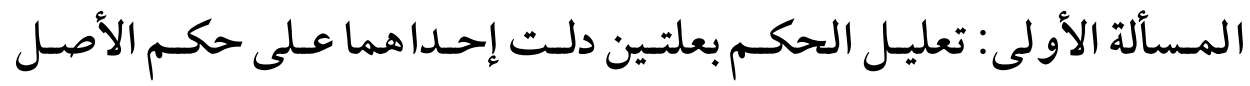
والأخرى لم تدل عليه.

المسألة الثانية: زوال إحدى العلتين في الحكم المعلل بعلتين.

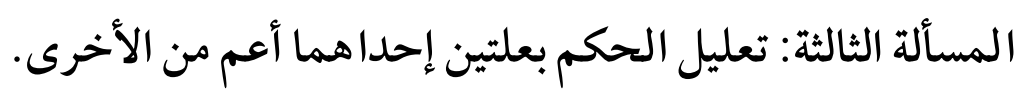

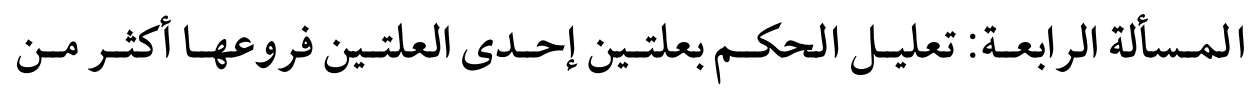

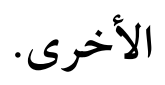

المسألة الخامسة: تعليل الحكم بعلتين إحـداهما قاصرة والأخرى متعديـة،

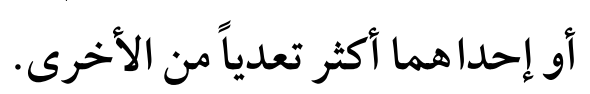

المسألة السادسة: الترجيح بكثرة العلل.

وأما المبحث الرابع: ففي أثر تعدد العلل عند الأصوليين، وفيه عشرة مطالب:

$$
\text { المطلب الأول: إحداث علة بعد علة. }
$$

المطلب الثاني: القياس على ما ثبت بالقياس. المطلب الثالث: وجود الحكم مع عدم العلة (عدم التأثير ). 
$(\Lambda \Lambda Y)$

تعلد العلل وأثره عند الأصولييز "دراسة أصولية تطبيقية"

المطلب الرابع: انتفاء الوصف المعارض غير المنافي للعلة.

المطلب الخامس: الفرق أو المعارضة في الأصل بمعنى أخر.

المطلب السادس: فساد الإلغاء أو تعدد الوضع.

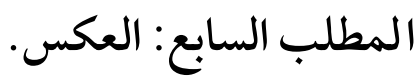

المطلب الثامن: الوصف الذي جعل ضـابطاً لحكمته يجـب أن يكسون جامعاً

للحكمة.

المطلب التاسع: من شروط الفرع: ألا يكون منصوصاً عليه لا إثباتاً ولا نفياً.

المطلب العاشر: من شروط العلة: أن تكون متحدة في الأصل. ثم الخاتمة في أهم نتائج البحث، ثم فهرس الموضوعات.

منهجي في البحث:

منهجي في هذا البحث على النحو التالي:

1 - الاستقر اء والتبع للموضوع مسن خـلال المر اجـع والمصادر الأصسولية

الأصيلة المتعلقة بالموضوع، وأحياناً أنقل النص من مصدره.

r - التحري والتحقق في نسبة المـاهب والأقوال إلى أصحابها، وأحياناً

أنقل النص الدال على ذلك من كتبهم.

r- الرجـوع إلى المـصادر والمراجـع التراثية الأصلية مـن كتب الأصـول

وغيرها بالإضافة إلى الكتب الحديثة مع التزام الدقة في العزو والتوثيق.

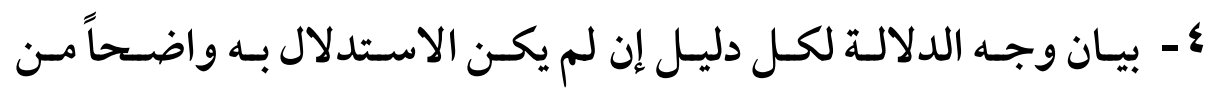

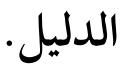




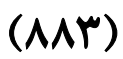

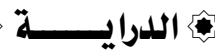

هـ - نسخخ الآيـات القرآيـة مـن المصحف العثماني وعزوهـا بــكر اسـم

$$
\text { السورة ورقم الآية. }
$$

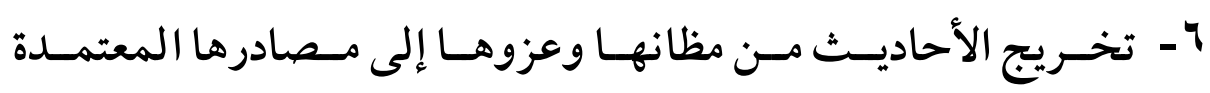

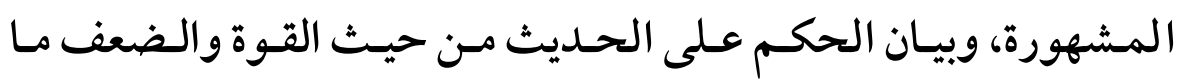

أمكن باستثناء ما أخرجه البخاري ومسلم أو أحسئ أحدهما.

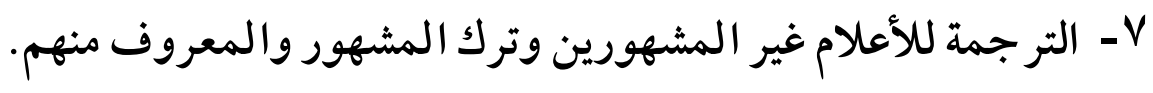

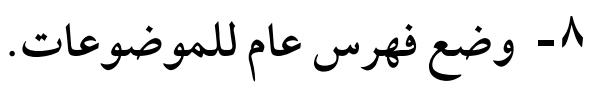


$(\wedge \wedge \varepsilon)$ تعلد العلل وأثره عند الأصولييز "دراسة أصولية تطبيقية"

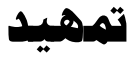

\section{في تعريف العلة}

أولاً : تعريف العلة في اللفة:

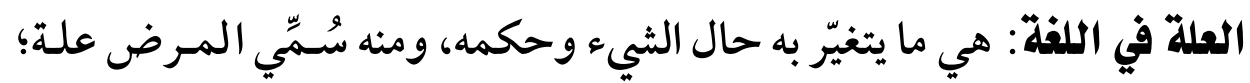

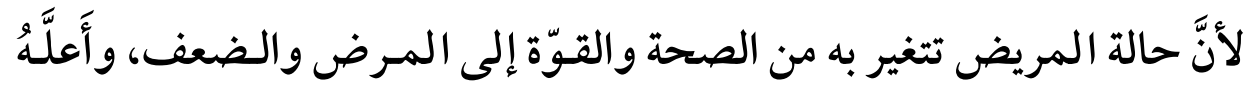

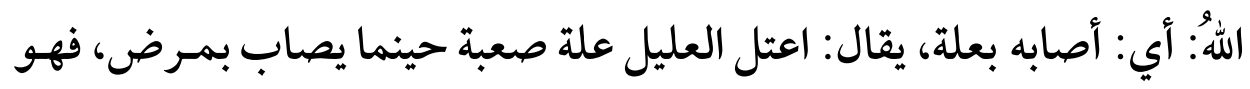

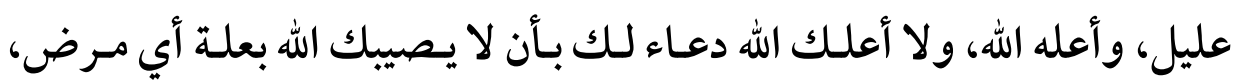
وحروف العلة سميت بذلك للينها وضعفها ومو تها.

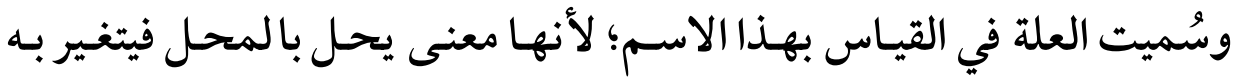

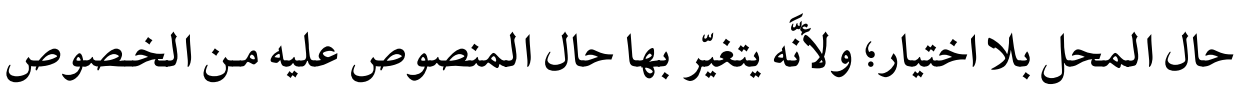

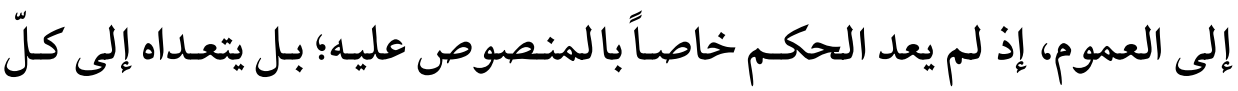
واقعة وجدت فيها العلّة. وقيل: لأنهَّا ناقلة حكم الأصل إلى الفـرع، كالانتقال بالعلة مـن الصحة إلى

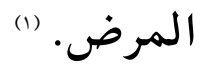

(1) انظر : لسان العرب لمحمد بن منظور الأفريقي المصري II / I I ـ النـاشر : دار صادر -بيروت، الطبعة الأولى، مختار الصحاح لأحمـد بـن محمـد بـن علي الفيومي

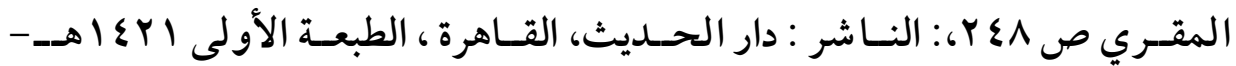




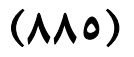

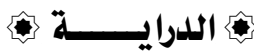

قال الجرجاني في تعريفها:" العلّة لغة عبارة عـن معنى يحـلّ بالمحَلّ فيتغير

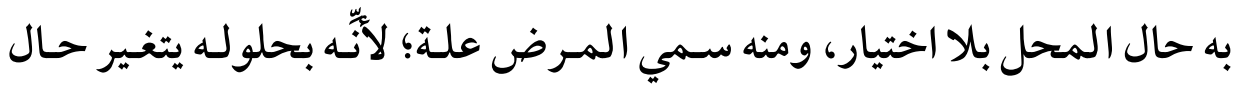

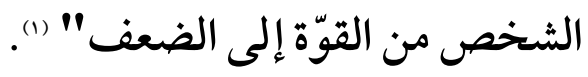
وقيل: هي مأخوذة من العلل بعـد النهل، وهو معـاودة الشرب مـرة بعـد مـرة؛

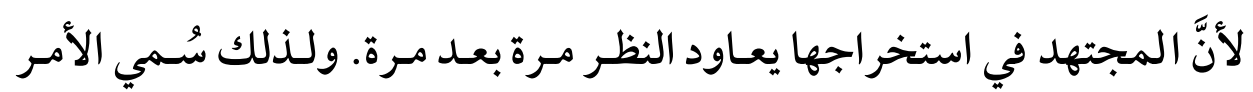
المثبت للحكم في الشرع علة لتكرره بتكرره.

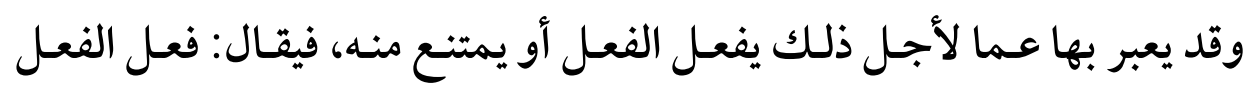
لعلة كيت، أو لم يفعل لعلة كيت.

(1) التعريفات للجرجاني ص \& 10 1، الناشر : دار الكتب العلمية بيروت -لبنان، الطبعة

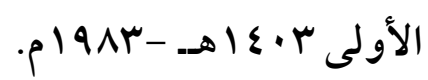

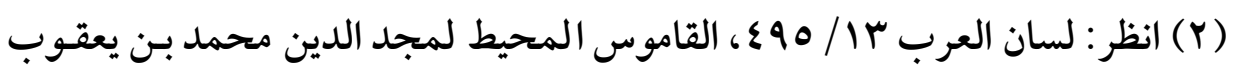

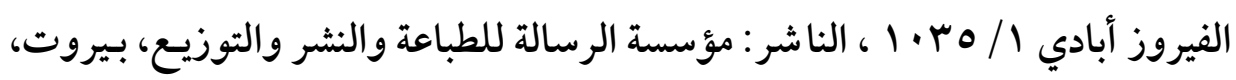

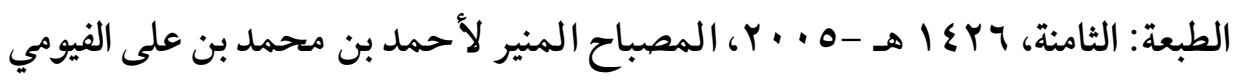

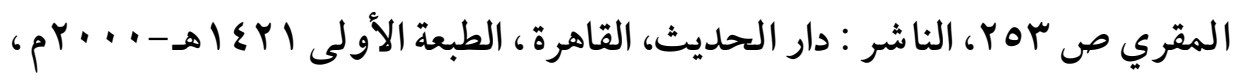
العين للخليل بن أحمد الفراهيدي / / / النـاشر : دار ومكتبة الهلال - تحقيق : د.

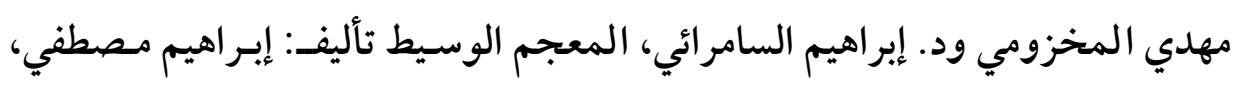

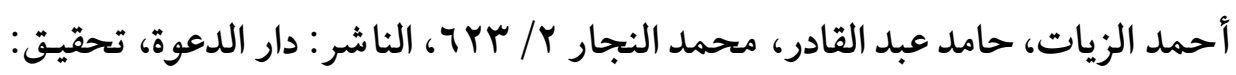

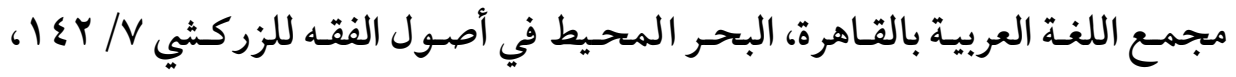

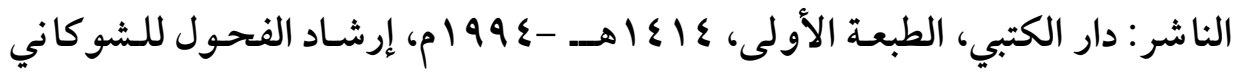

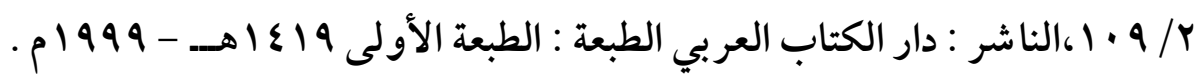


(A^Y)

تعلد العلل وأثره عند الأصولييز "دراسة أصولية تطبيقية"

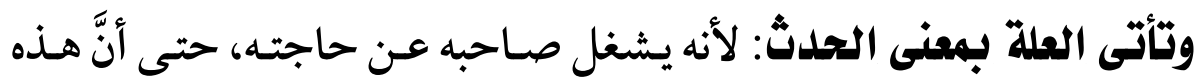

العلة صارت شغلاً ثانياً منعه من شغله الأول.

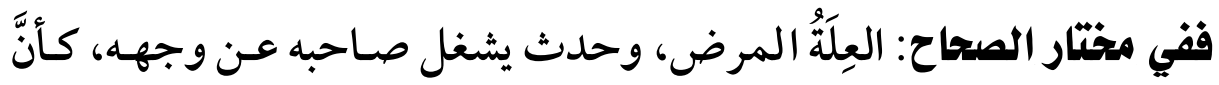

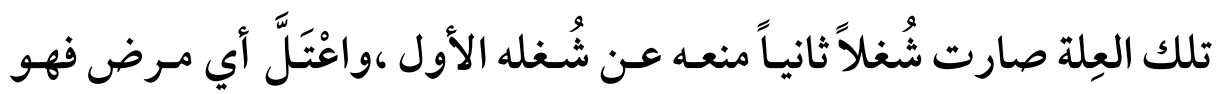

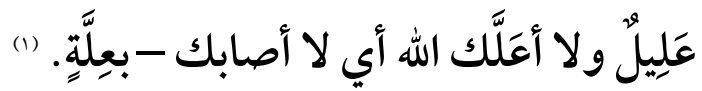

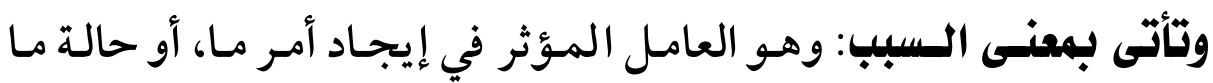

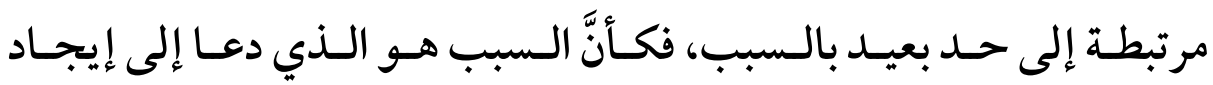
المسبب.

وتأتى العلة بمعنى العـذر، وهـو التأسـف الـذي يلجـئ إلى تلمـس الأسباب

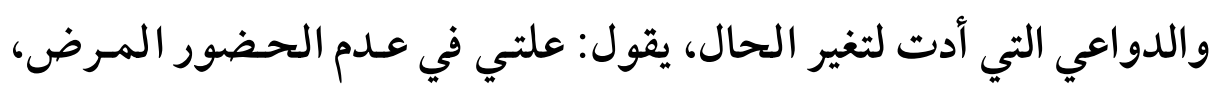

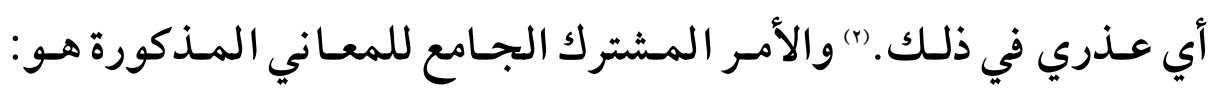
تغيير الحال بسبب اعتر اض أمر ما يدعو للتغيير. ثانياً: تعريف العلة في الاصطلاح

اختلف الأصوليون في تعريف العلة، والمشهور أنَّ لهم فيها أربعة مـذاهب الاصب هي: المـذهب الأول: قـال في تعريفها هي : وصـف ظـاهر منـضبط معـرف للحكـم بوضـع الشارع، وهـذا مـذهب جمهـور الأصسوليين مـن الشافعية، والحنابلة،

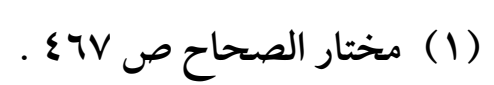

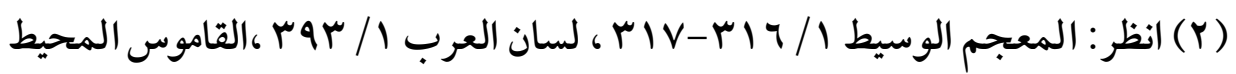

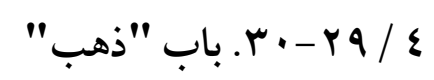


واختاره الرازي، والبيضاوي، وابن السبكي، رحمهم الله أجمعين. (1) أي أنَّها

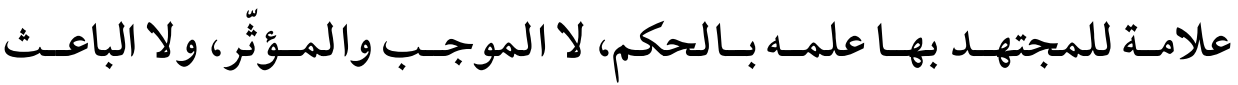

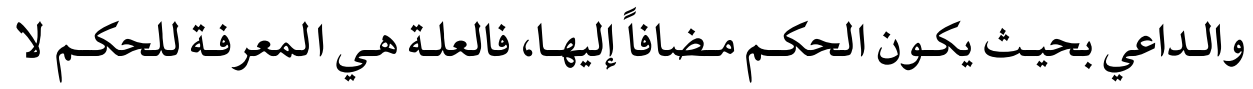

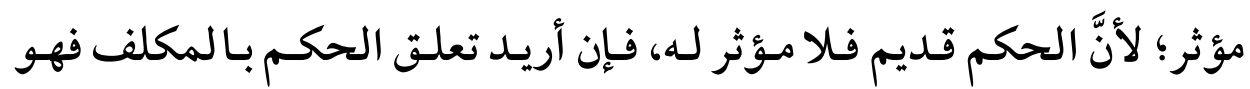
بإرادة الله تعالى لا بتأثير شيء من العالم. (r)

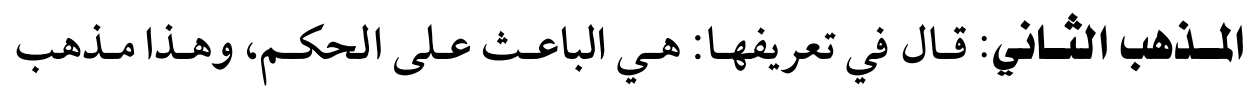

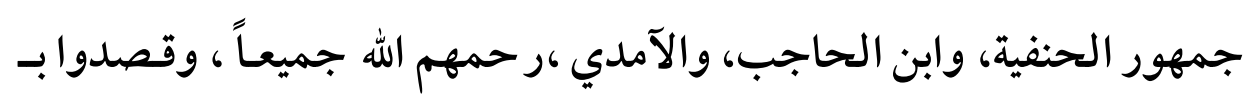

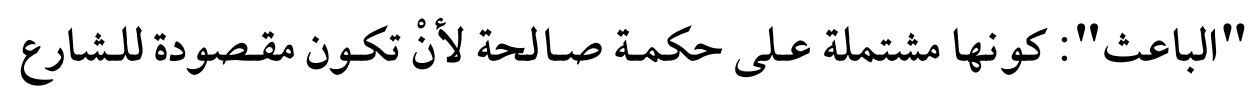

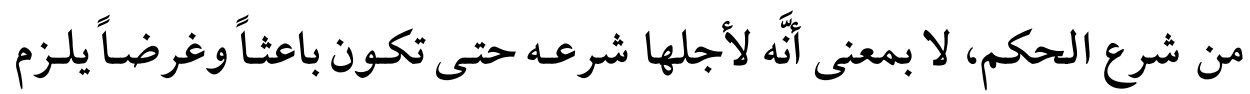

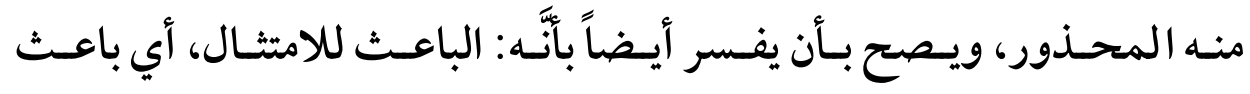

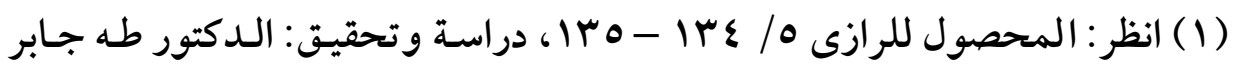

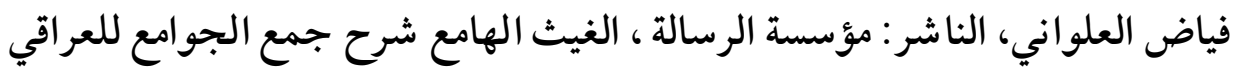

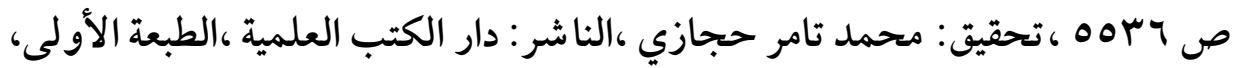

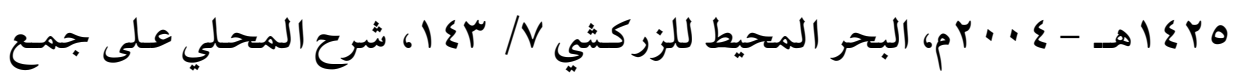

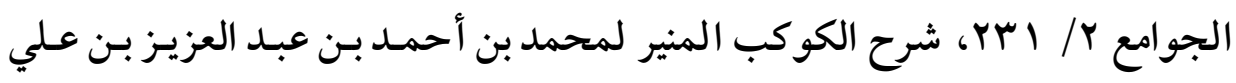

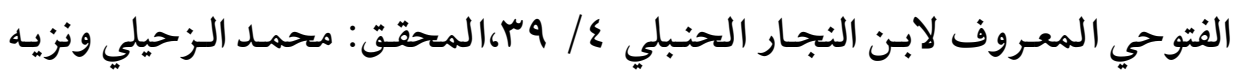

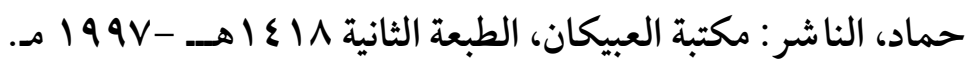

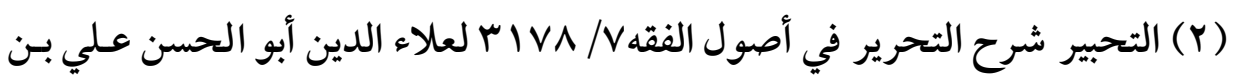

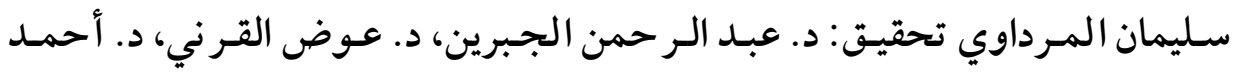

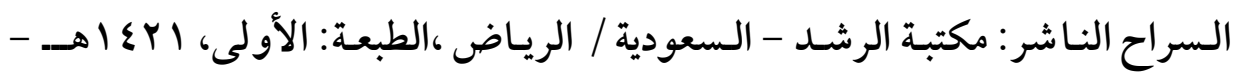


$(\Lambda \wedge \Lambda)$

تعدد العلل وأثره عند الأصوليين "دراسة أصولية تطبيقية"

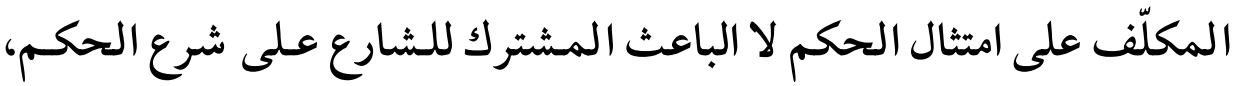
كما هو ظاهر اللفظ؛ لأنَّ الله تعالى لا يبعثه شيء على شرع حكم سـوى إرادته له، له يخلق ما يشاء و يختار . (1)

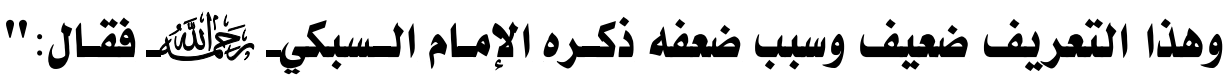

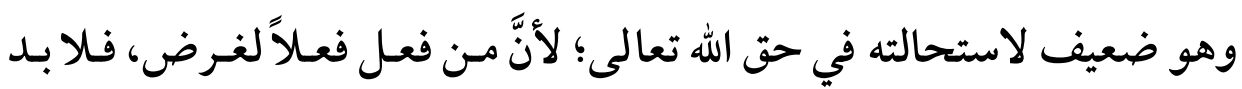

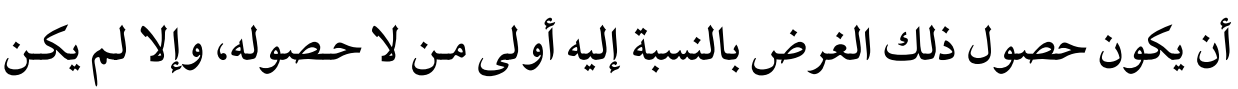

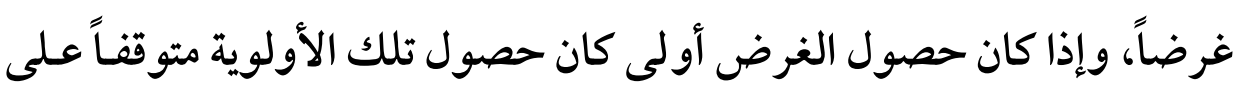

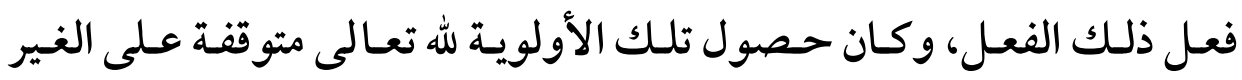
فتكـون ممكنـة غير واجبـة لذاتـه، ضرورة توقفها عـلى الغسير، فيكسون كمالـه تعالى ممكناً غير واجب لذاته وهو باطل "().

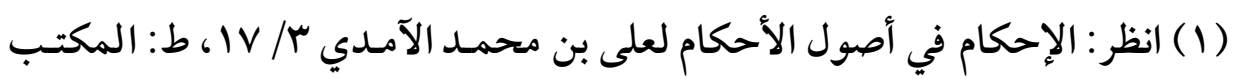
الإسلامي -بيروت. ، شرح العضد للإيجي / / / ا ب ، الناشر : دار الكتب العلمية، الطبعة الثانية ب.ـ أهـ، التوضيح شرح التنقيح لسعد الدين مسعود بن عمر التفتازاني

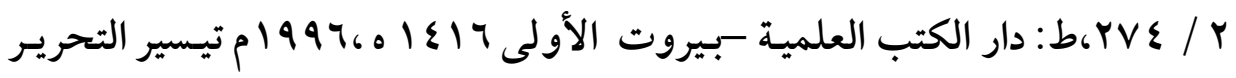

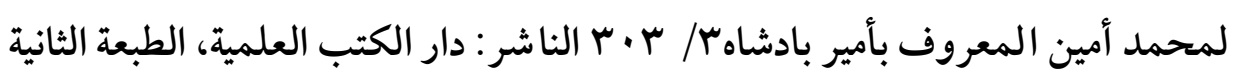

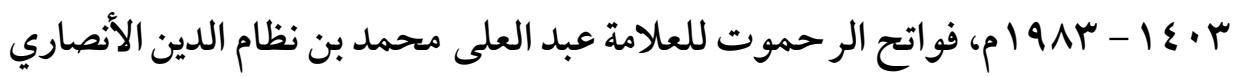

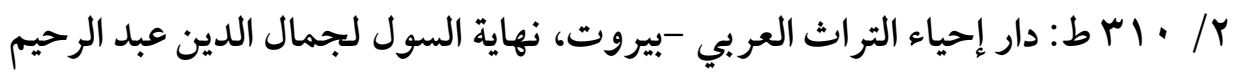
الإسنوي r/ / 101 1ط: دار الكتب العلمية-بيروت ، أصول الفقه للشيخ محمد أبو النور زهير \& / الآو ما بعدها. الناشر: المكتبة الأزهرية للتراث.

$$
\text { (r) الإبهاج /r/ • ع. }
$$


المذهب الثالث: قال: العلة هي الوصف المؤثر بجعل الشارع لا لذاته، وهـا

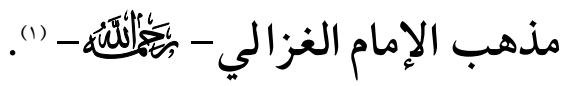

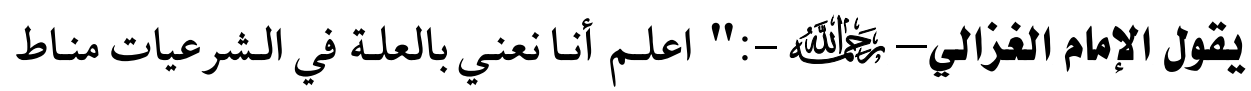

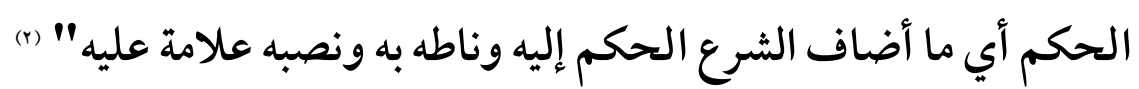

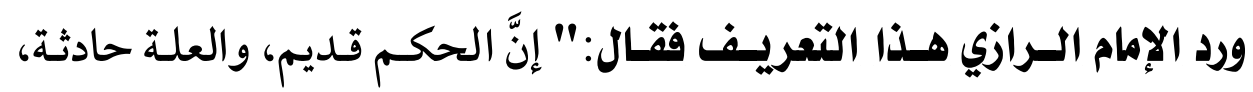

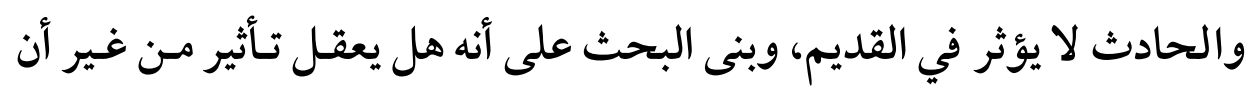

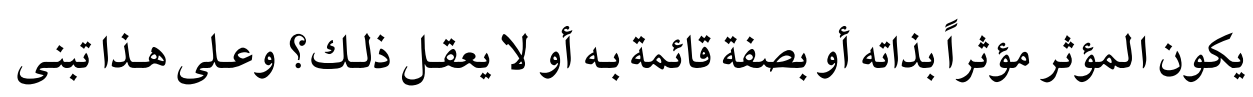

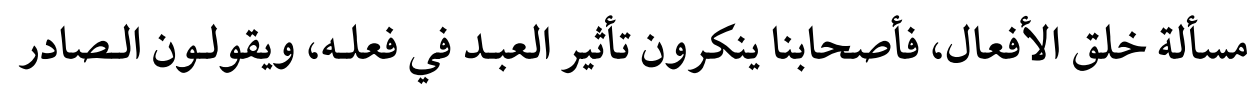

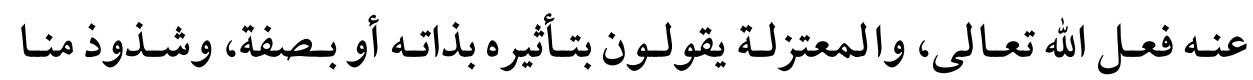
توسطوا فقالو ا بمثل كلامهم هنا في السببية ويلزمهم. (r)

(1) انظر : شفاء الغليل للغزالي ص · بوما بعدها ، تحقيق: د. حمد الكبيسي. الناشر:

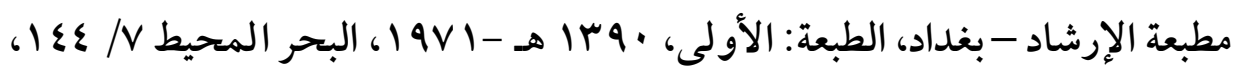
نهاية السول س/ ؟ـ.

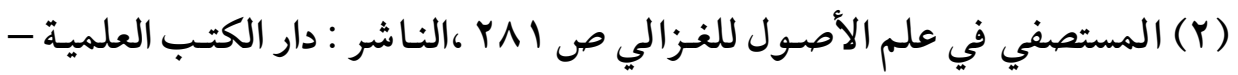

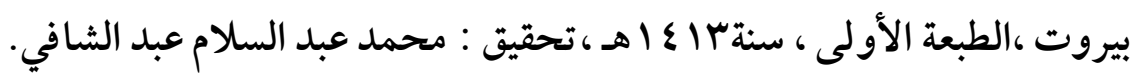

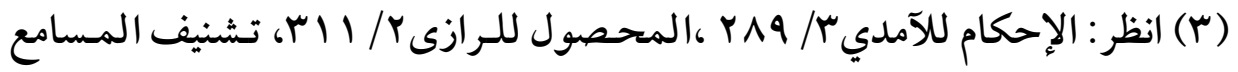

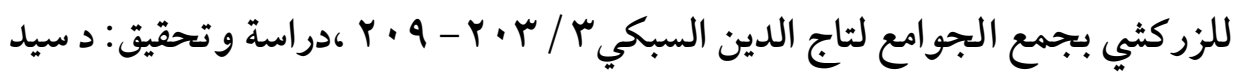

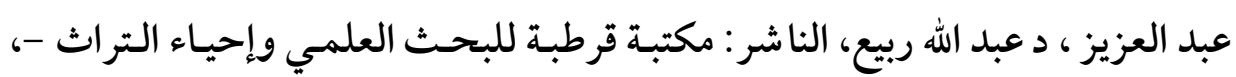

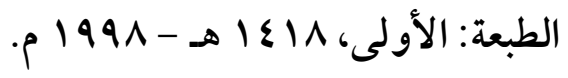




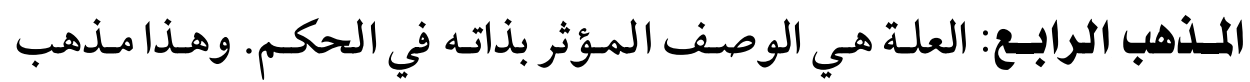
المعتزلة (1) - 20 - n

$$
\text { وهذا القول مبني على التحسين و التقبيح العقلين. }
$$

وقد أبطل أهل السنة التحسين والتقبيح العقليـين عند المعتزلة بـردود قويـة لا مجال لذكرها هنا (r).

والتعريـف الـراجح هـو التعريــف الأول ـتعريــف الجمهــور - : وذلك لأنَّ الشارع نصب الأوصاف الظاهرة علامة على الأحكام؛ تيسيراً على العباد في : ولي

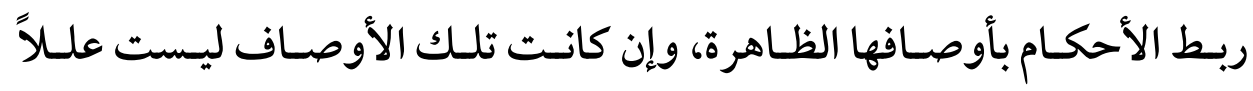

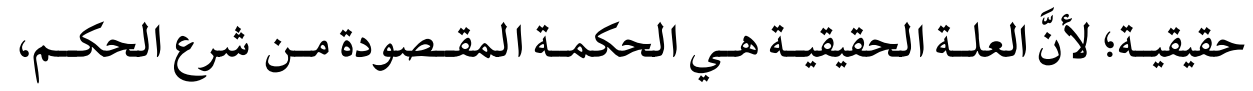
فالسرقة وصف ظاهر لوجوب القطع، أما العلة الحقيقية لوجوب القطع فهي

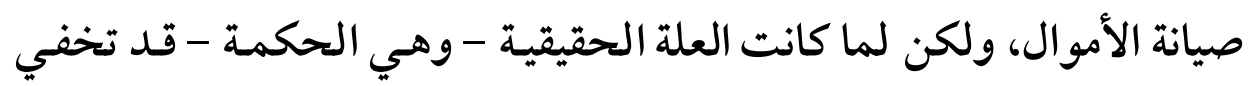
ولا تنضبط، ويتعذر الوقوف على حقائق مقاديرهـا؛ لاخـتلاف مر اتبها التي لا

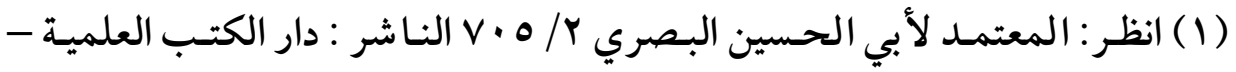

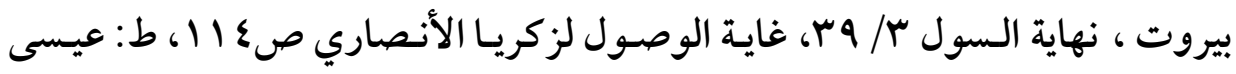

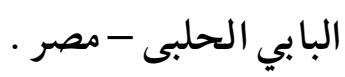
(Y) انظر كلام العلماء في الرد على التحسين والتقبيح عند المعتزلة في: الإحكام

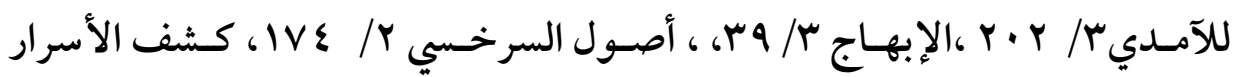

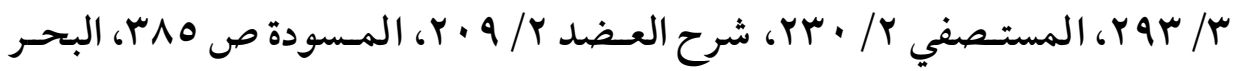

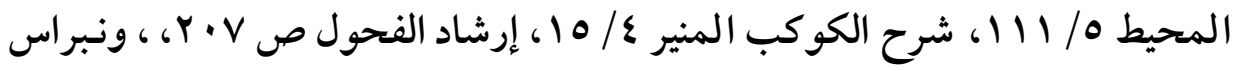


(A91)

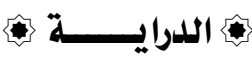

نهايـة لهـا بحسب الأشـخاص والأزمـان والأحسوال، ولـيس كـل قـدر منهـا

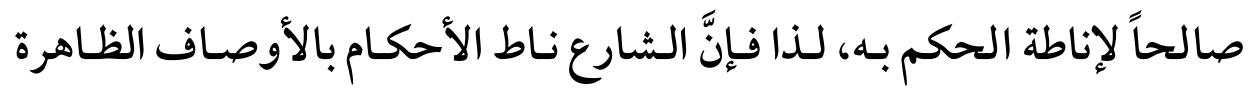
المنضبطة كالسفر مثلاً، فإنه نيط به حكم قصر الصلاة والإفطار في رمضان، ولم يـنط بالمـشقة التي هي العلة الحقيقيـة؛ لمـا ذكر مـن اخـتلاف مر اتبها، وعدم انضباطها (1)

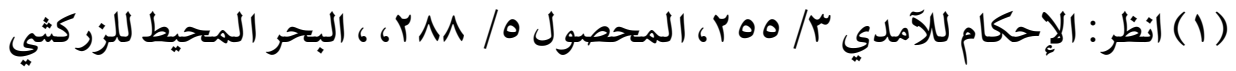

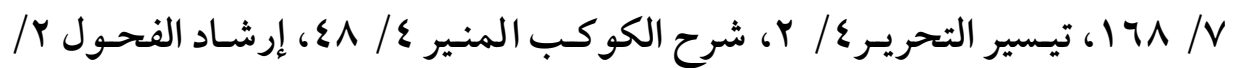
V•T، نهاية السول \&/ rTr. 


\section{البمث الأول}

المراد بتعدد العلل، والفرق بينه وبين العلة المركبة

\section{الإطاب الأول}

\section{المراد بتعدد العلل المل المل}

تعدد العلل مفنـاه: وجـود أكثر مـن علة لحكـم واحـد، كل واحـدة مختلفـة ومستقلة بذاتها لا تعلق لهابغيرها.

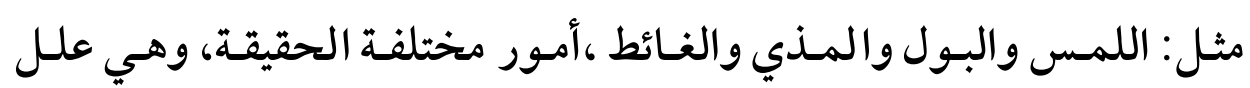
مستقلة للحدث لثبوت الحدث بها.

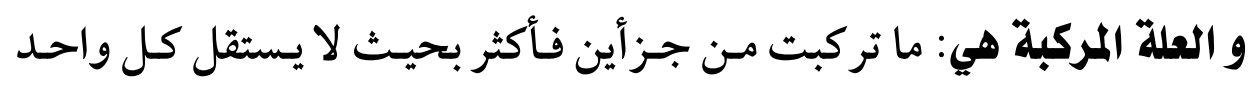
منها بالعلية. مثل: القتل العمد العدوان في وجوب القصاص. مناصن

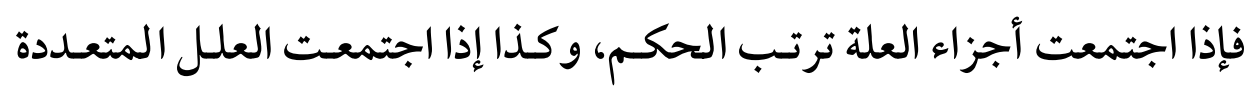

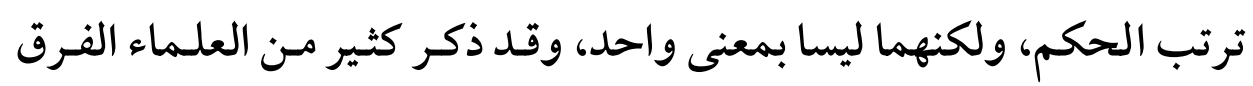
بين أجزاء العلة أو العلة المركبة والعلل المتعددة.

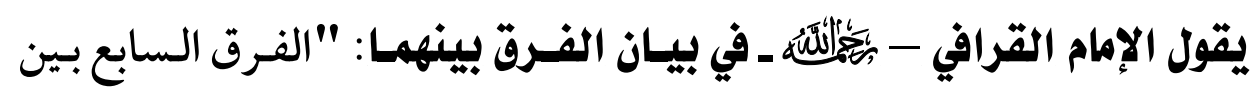

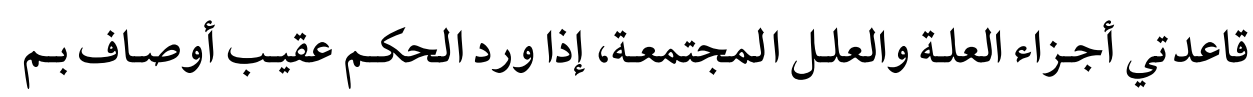
يعلم أنها أجزاء علة أو أنها علل مجتمعة وأي فرق بينهما.

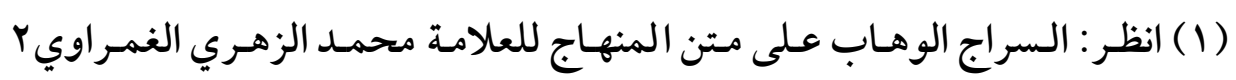

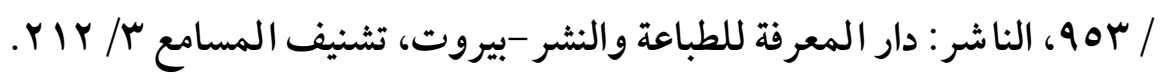


والجواب: أنَّ الحكـم إذا ثبـت عقيـب أوصـاف، يُنظر إن كـان صـاحب الشرع رتـب ذلك الحكـم مـع كـل وصـف منها إذا انفـــد قلنـا: هي علل مجتمعـة،

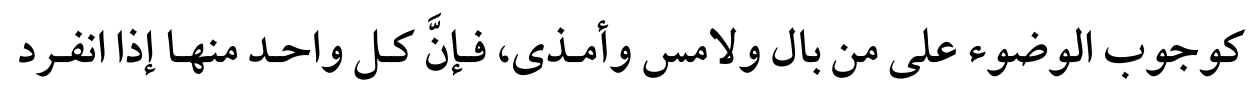
استقل بوجوب الوضوء، وكإجبار الأب لابنته البكر معلل بالصغر، والبـ والبكارة

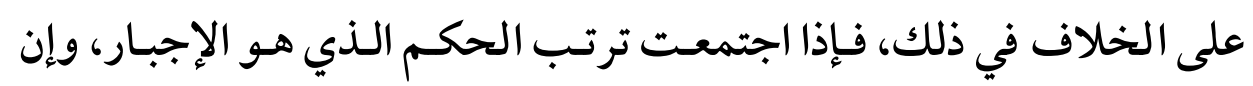

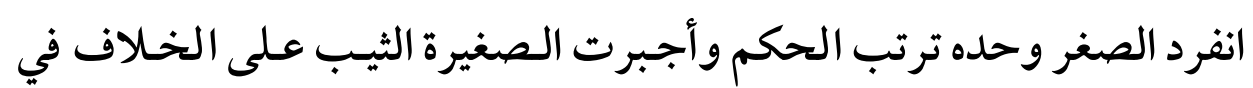

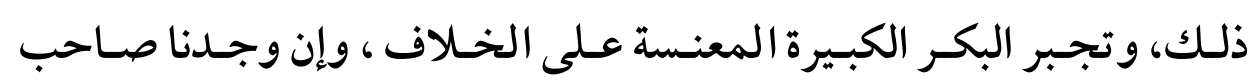
الشرع لا يرتب الحكم مع كل واحد منها قلنا: هي علة واحدة مركبة مـن تلك الأوصاف كالقتل العمد العدوان، فبهذا يعلم الفرق بين هاتين القاعدتين وهـو ضابطهما وتحرير هما. (1) فالحكم يثبت بعلة واحدة من العلل المتعـددة وبجميع أجزاء العلـة في العلة المركبة لا بجزء علة، فالحكم لا ينقسم على أجزاء العلة لاستـلز امه صسيرورة

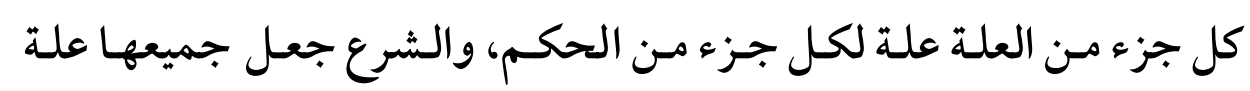

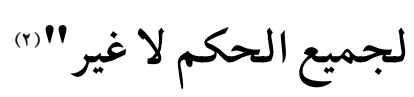

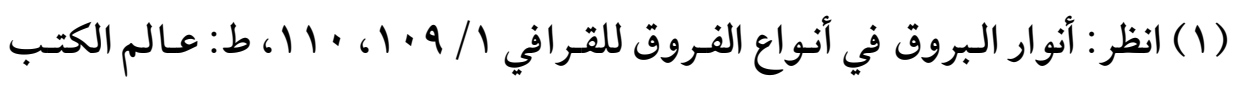

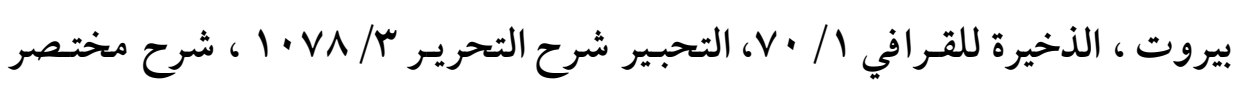

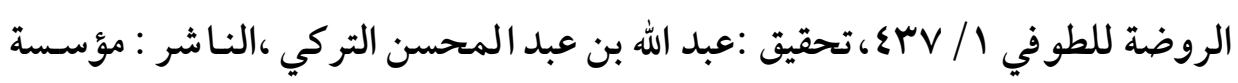

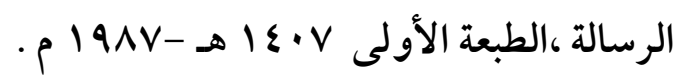
، مار لكتب العلميـة

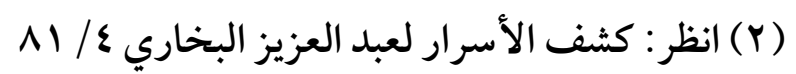

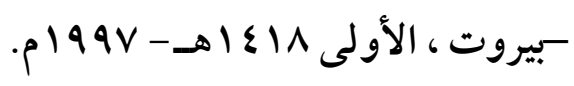


(^৭६)

تعلد العلل وأثره عند الأصوليين "دراسة أصولية تطبيقية"

هذا :ويشترط في أجزاء العلة أن يكون كل جزء منها مؤثراً في الحكـم وإلالا لا يصح التعليل بها.

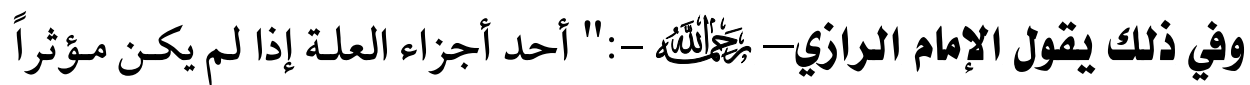

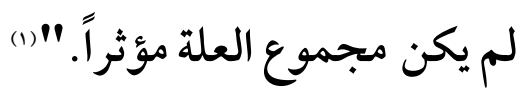
و يجوز في أجزاء العلة أن يتر جح بعضها على برولى بعض، وأن يكون بعضها أقوى من بعض فهى تتفاوت.

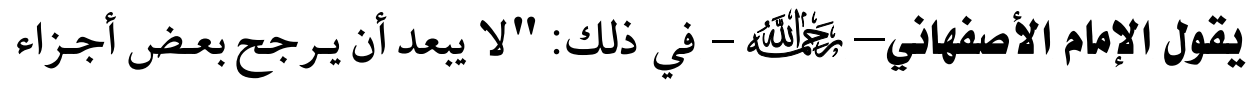

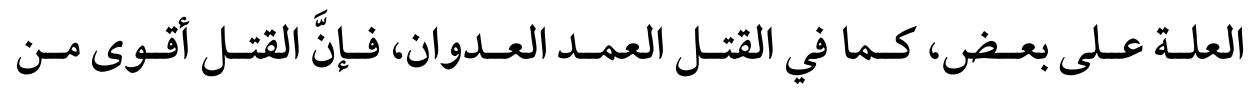

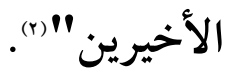
وفـرق بعضض الأصسوليين بـين تعـدد العلل والعلـة المركبـة مـن حيـث جـواز التعليل بهما أو عدمه.

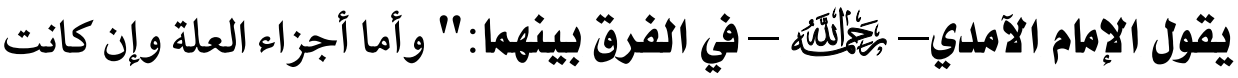
مناسبة فإنما يمتنع التعليل بكل واحد منها لما سبق مـن امتنـاع تعليل الحكـم

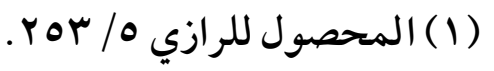

(Y) بيان المختصر شرح مختصر ابن الحاجب لمحمود بن عبد الرحمن الأصفهاني

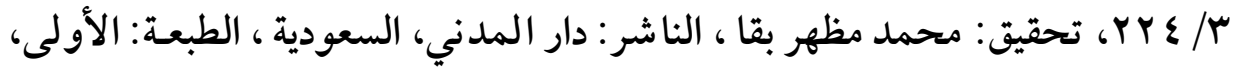
. $1914 / 81 \xi \cdot T$ 
(190)

الو احد في محل واحد بعلل (1) بخلاف مـا إذا اتحـد الوصف أو تعـدد وكانت

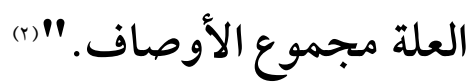
فالعلة تنقسم باعتبار كميتها إلى الوصف الواحـد، كالقذف علـة لإقامة الحـد

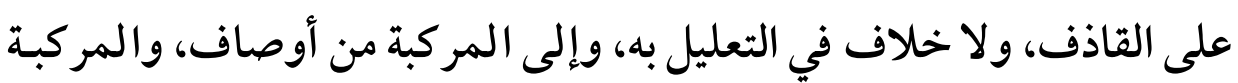

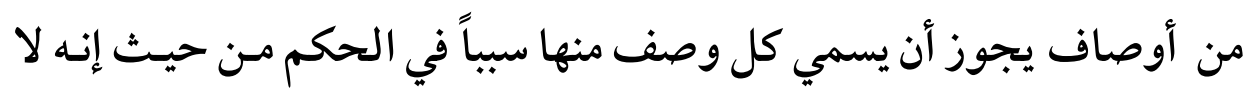
بد منه وليس كل وصف علة، وإنما العلة مجموع الأوصاف. (r)

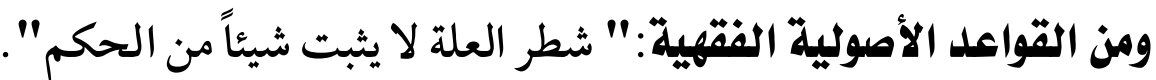

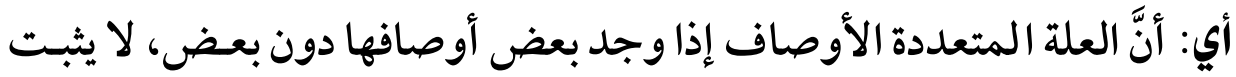
بذلك شيء من الحكم فلا بد من وجود جميع أوصافها لإثبات الحكم (s). هذا: والقول بجواز أن تكون العلة ذات أوصاف إنما يكون في العلة الشرعية

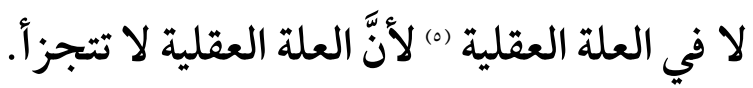

(1) مذهب الآمدي عدم جواز تعدد العلل على محل واحد كما سيأتي بيانه إن شاء الله تعالى.

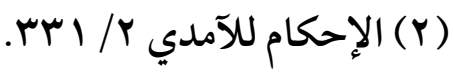

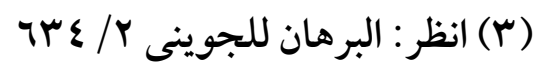

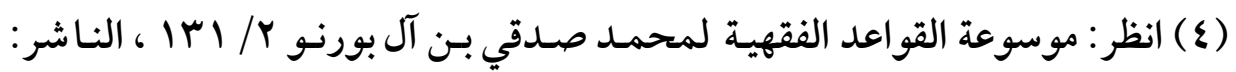

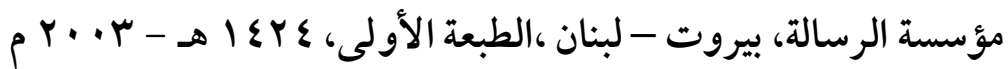

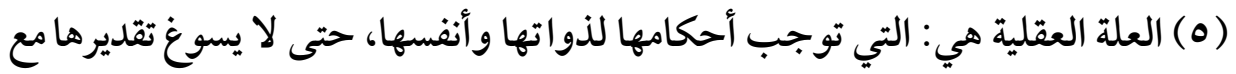

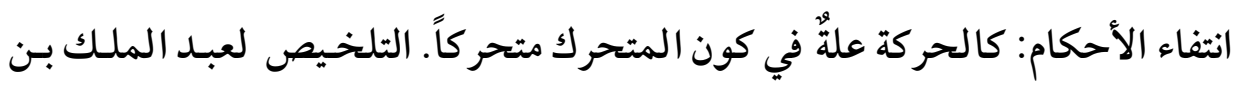

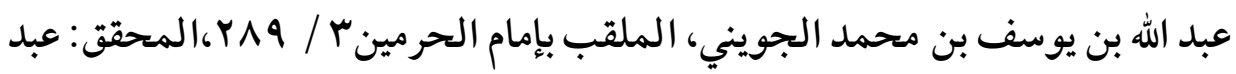


الله جولم النبالي وبشير أحمد العمري ،الناشر : دار البشائر الإسلامية - بيروت، البحر

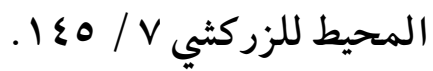

والفرق بين العلة الثرعية و العقلية أمور كثيرة منها:

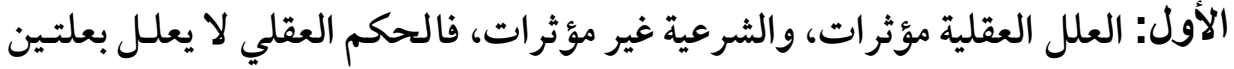
بخلاف الشرعي. الثاني: العلة العقلية توجب حكمها لذاتها، ولا يصح وجودها بـدون حكمها بخلاف

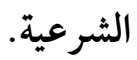
الثالث: العلة العقلية لا توجب حكمها لغير محلها، بخلاف الشرعية

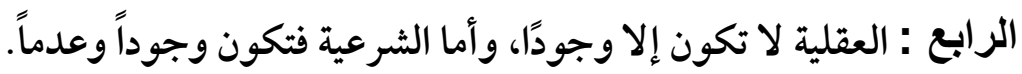

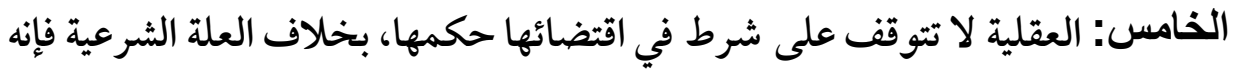

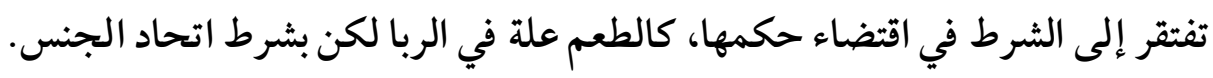

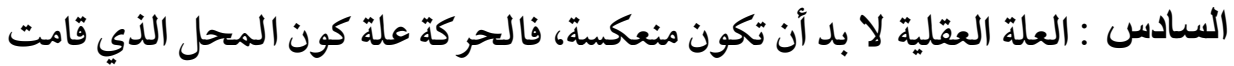
به متحر كاً، فيجب من ذلك: أن كل محل لم تقم به الحر كة، فلا يكون متحر كاً بحال.

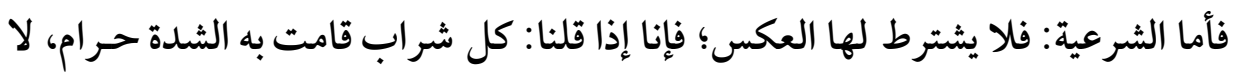

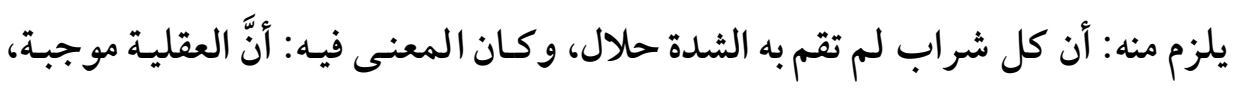

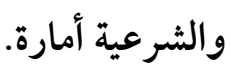
السابع: علة الحكم العقلي يجب أن تكون أبداً مقارنة له غير متقدمة عليه ولا متأخرة

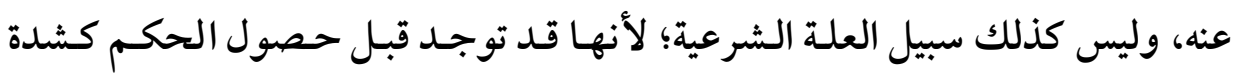

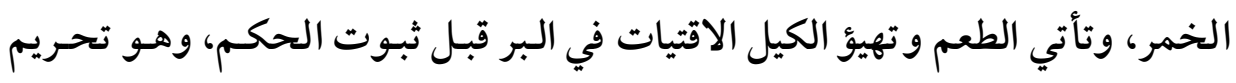

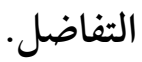
الثامن: العلة الشرعية يجوز أن توجب حكمين مختلفين، مثل إيجاب شـدة العصير

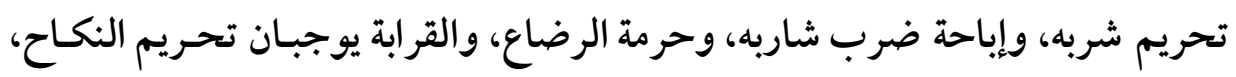

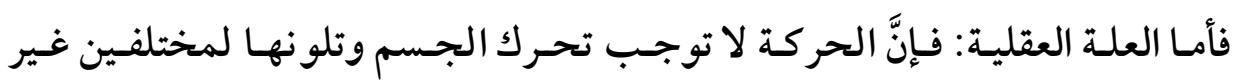




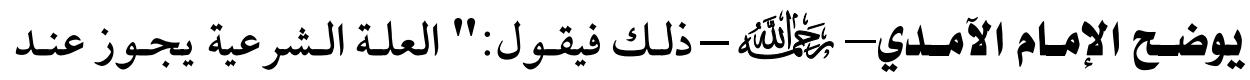
القائلين بالقياس أن تكون ذات أوصـاف، والعلة العقليـة ليست كـذلك فإنها تستقل بحكمها، كاستقلال الحركة بكون المحل الذي قامـت بـه متحركاً،

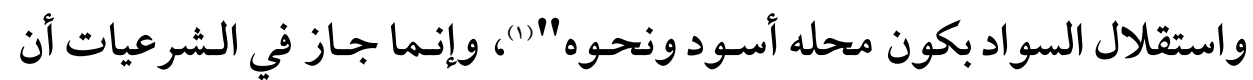

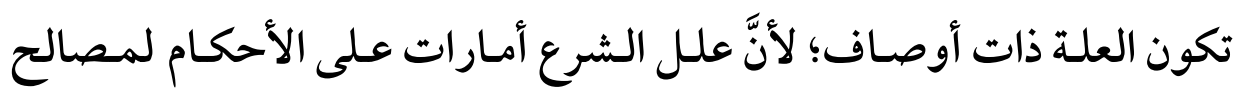
العبـاد، و يجــوز أن تتعلـق المـصلحة بوصـف واحسـد وبـاجتماع وصـفين وأوصاف، فيجب القول بالجواز. ومن الفروق بين تعدد العلل والعلة المركبة: أنَّ الحكم المعلل بـأكثر مـن علدة لا يبطله سـقوط بعضها، بخـلاف العلة المر كبـة إذا تخلف جـزء منها فإنها تكون باطلة لا يجوز التعليل بها.

المتضادين، ولا تحر كه وسكونه الموجبين المتضادين، ولا توجـب أيضاً حكمين

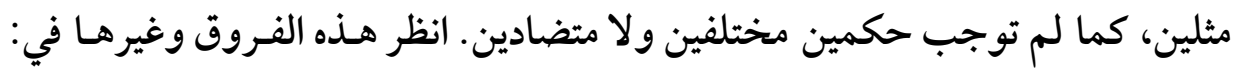

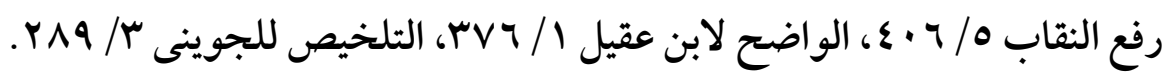

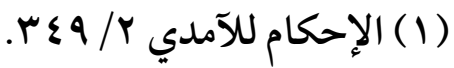

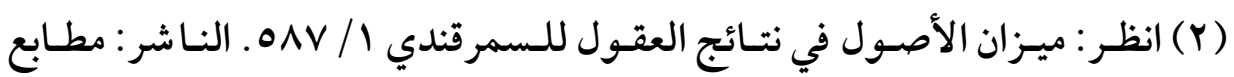

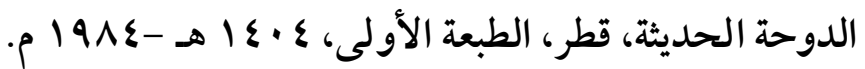

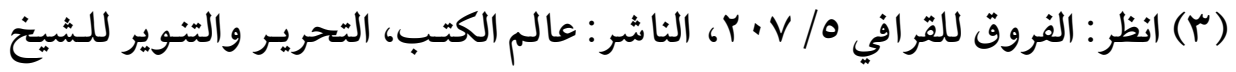

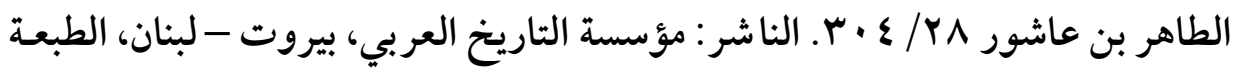

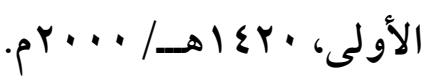


(^9^) تعلد العلل وأثره عند الأصولييز "دراسة أصولية تطبيقية"

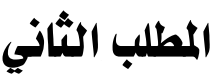

\section{حكم التعليل بالوصف المركب الماني}

اختلف الأصوليون في حكم التعليل بالوصف المركب مـن أجزاء لا لا يستقل كل واحد منها بالعلية على مذهبين:

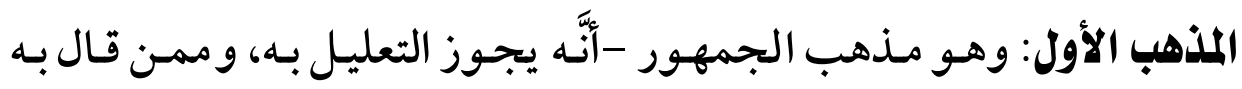
الإمام الفخر الرازي، والإمام الآمدي، والإمام ابن الحاجب - رحمهم الله.

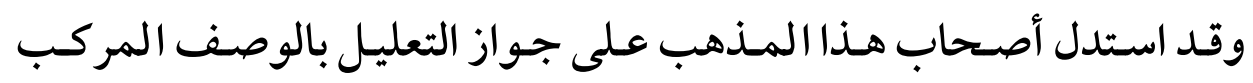
بدليلين:

الأول: أنه لا يمتنع أن تكـون الهيئة الاجتماعية مـن الأوصـاف المتعـددة ممـا

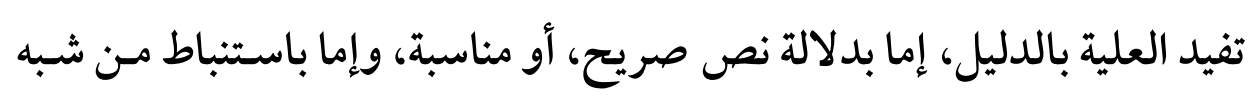

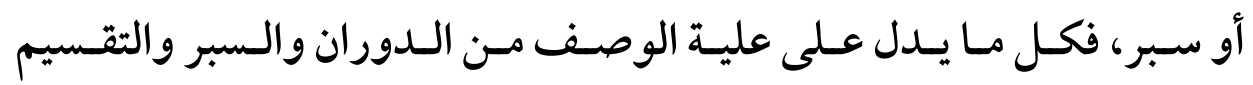

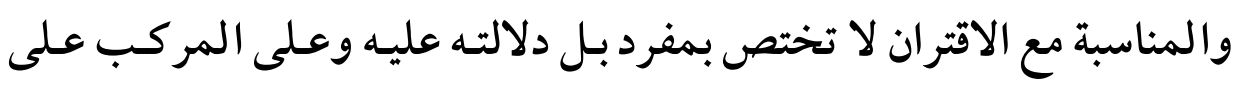

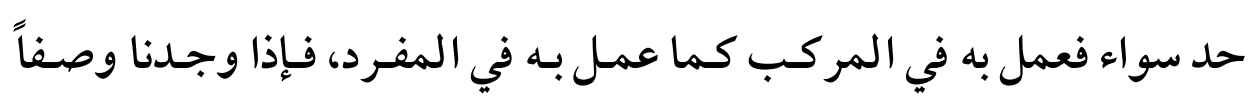

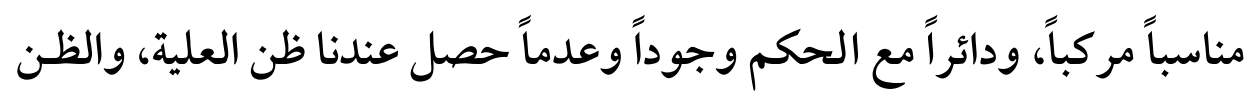

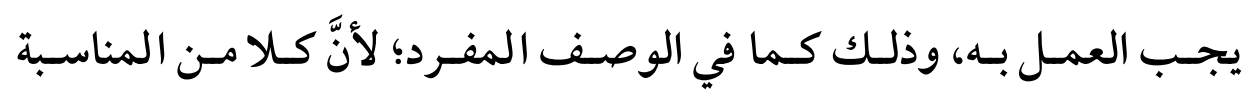
والدوران طريق من طرق إثبات العلية للوصف، وتثبـت بـه علية المفرد، وما ثبتت به علية المفرد، تثبت به علية المركب من غير فرق، والفرق تحكم. (1)

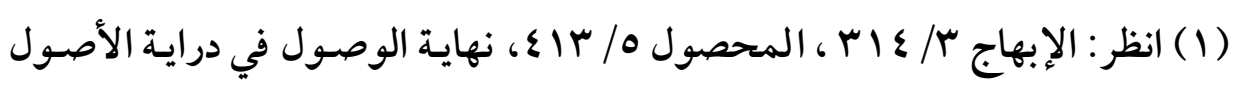
rolr./A 
(199)

الثـاني: أنَّ المصلحة قـد لا تحصل إلا بالتر كيـب؛ لأنَّ الوصف الواحـد قـــ

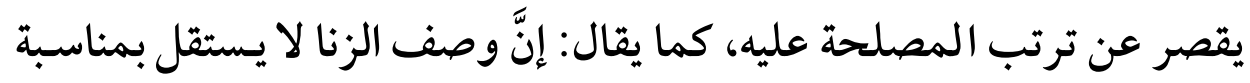

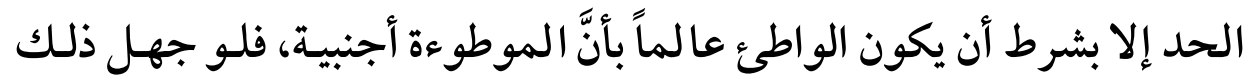

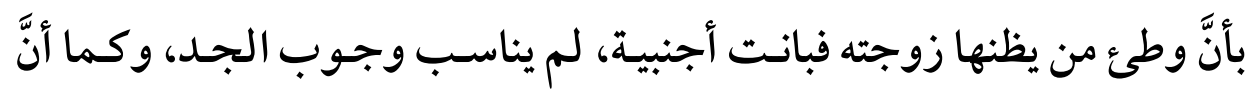
القتل وحده لا يناسب وجوب القصاص حتى يضاف إليه العمد العدوان. (1)

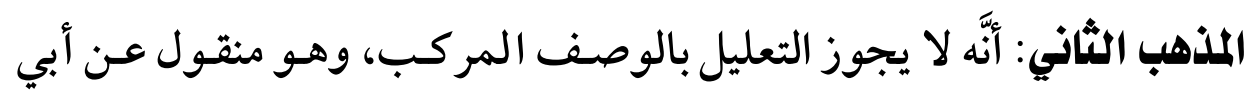

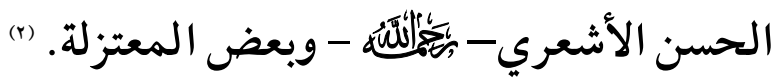

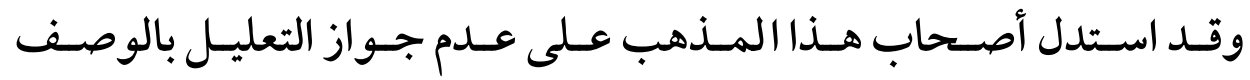

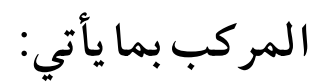

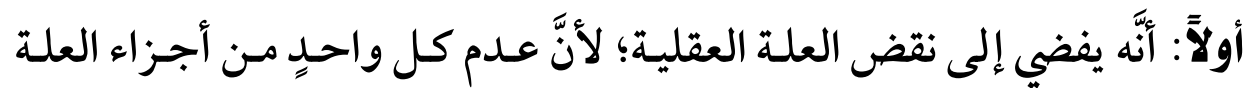

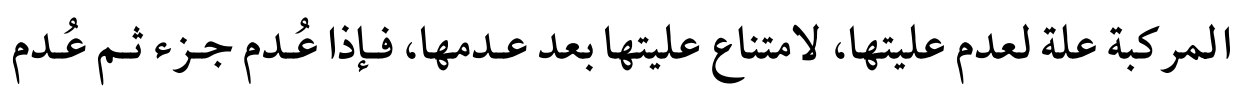
آخر حصل النقض. فإن قلثَ: هذا ينفي الماهية المركبة. قلتُ الماهية مجمـوع الأجزاء فلـم يكن عدم أحد الأجزاء علةً لشيء، والعلية أمر زائد عدمها معلل بعدم الأجزاء.

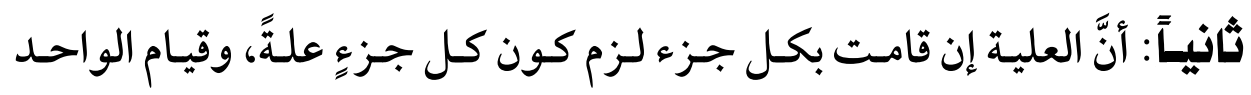
بمحال كثيرة، وإن قام بكل جزء انقسمت العلية فيكون لها نصف وثلث.

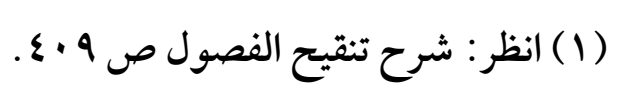

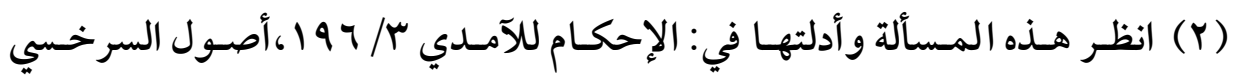

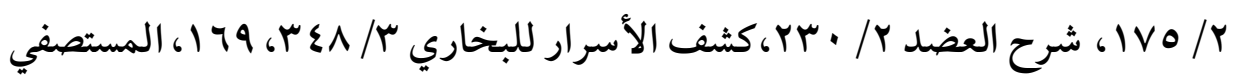

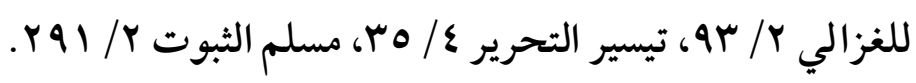




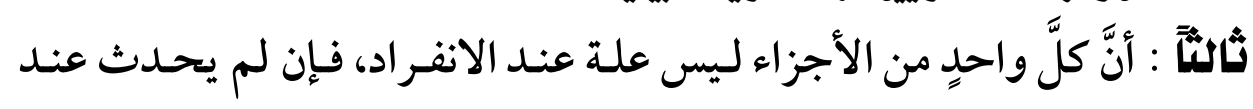
الاجتماع زائد لم يكن علة. وإن حدث عاد الكلام في المقتضي له وتسلسل.

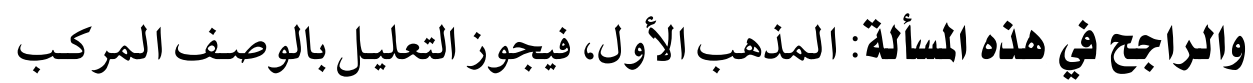

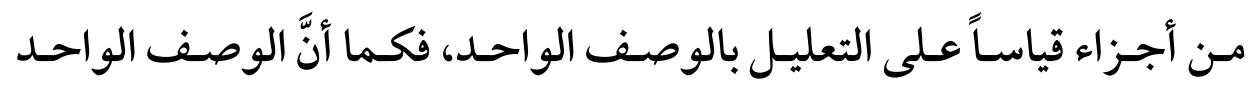

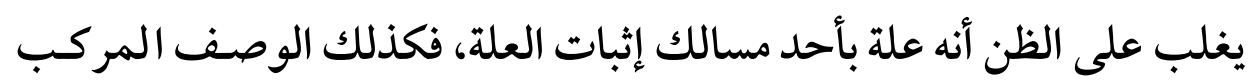

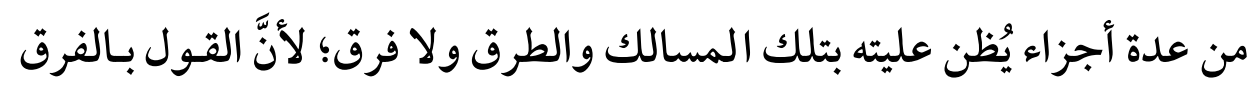

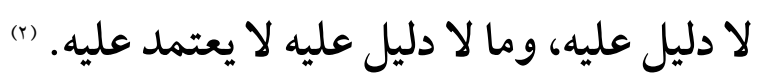

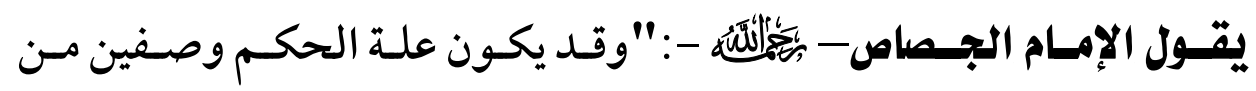

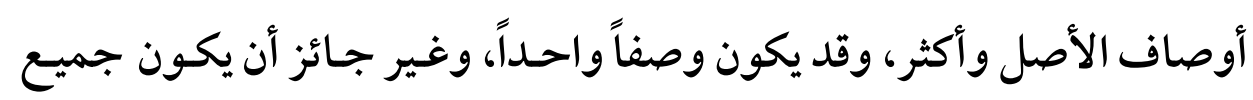

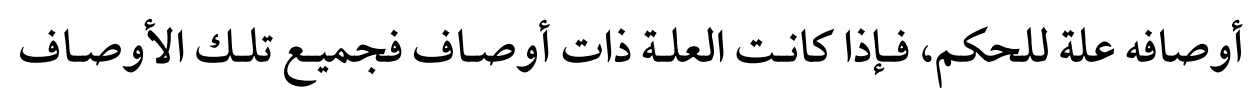

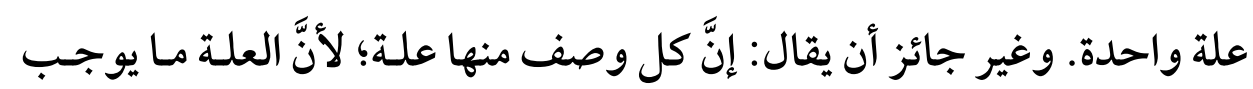

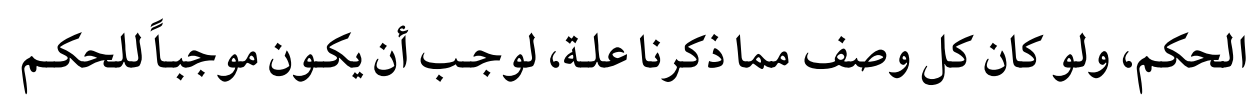

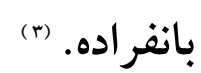

(1) انظر: الفائق في أصول الفقـه / 1 • ، التحصيل من المحصول لسراج الدين

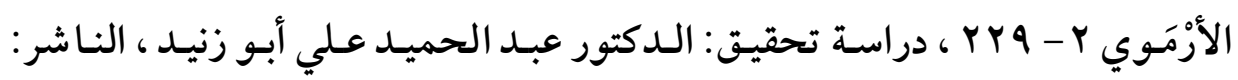

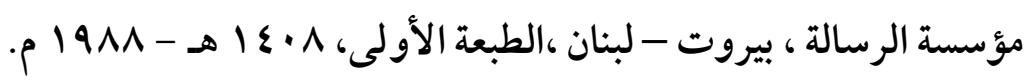

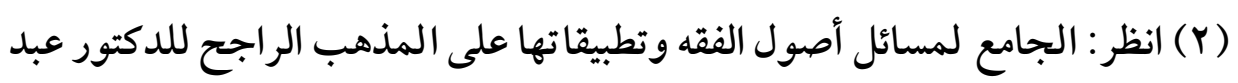

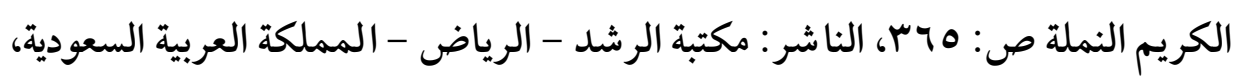

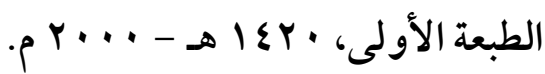

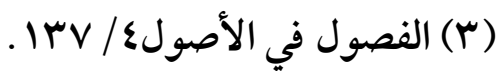


نوع الخلاف في المسالة: قيل: الخلاف لفظي؛ لأنَّ من أجاز التعليل بالمركب

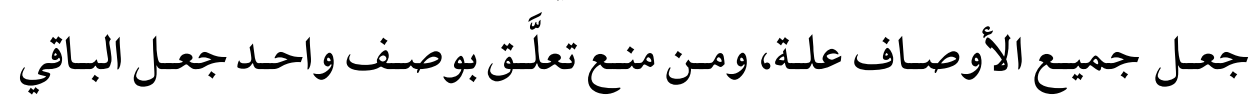
شروطاً لذلك الوصف. وقيل : الخلاف معنويٌ، وهو الراجح . "(1). تتمة: حكم زوال وصف من الأوصاف لا تأثير لله

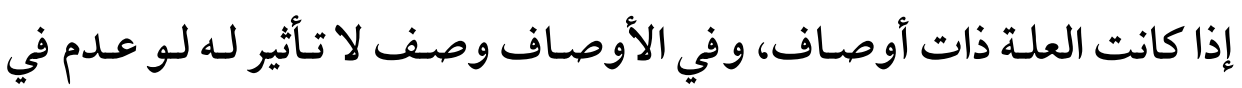

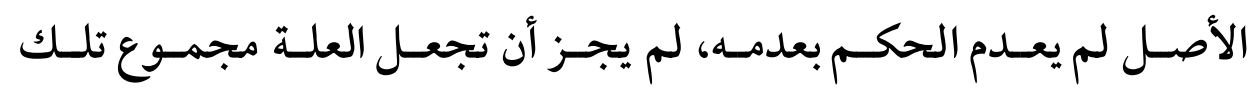
الأوصاف بل يجب أن يطرح ذلك الوصف عند أكثر العلماء، وهو الراجح.

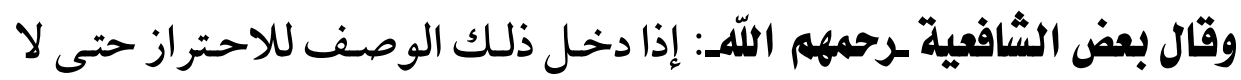
ينتقض بفرع من الفروع، جاز أن يجعل من جملة العلة، وذلك مثل قوله: في

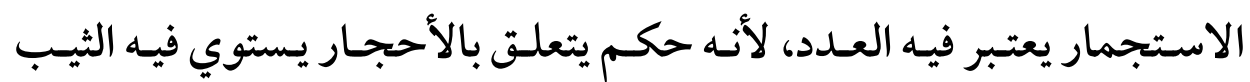

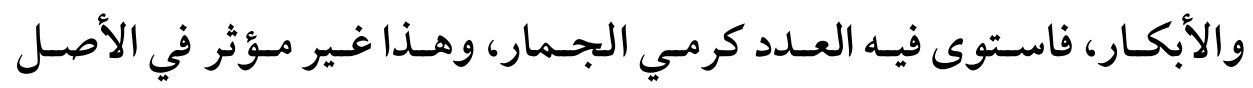

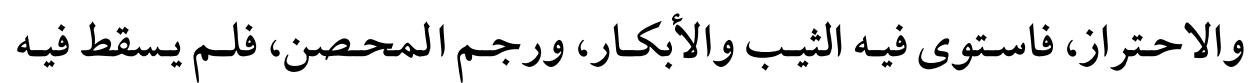

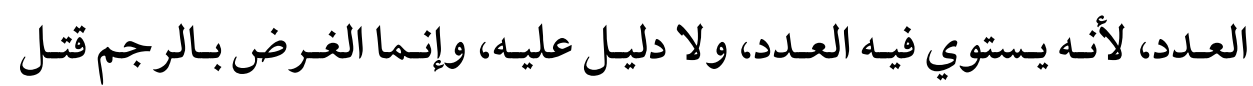
الزاني بأي حجر كان، ولا يطرح الأصل ولا الفرع.

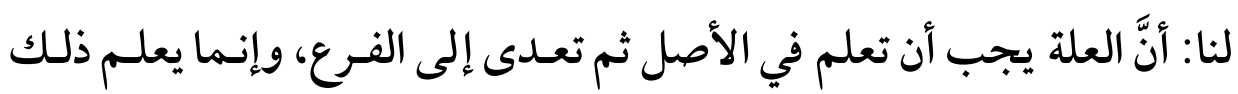
إذا كان الوصف مؤثراً في الأصل يوجد الحكـم بوجـوده، ويعـدم بعدمـه، فأمـا

(1) انظر : جمع الجوامع بحاشية البناني Y / ه ؟r، سلم الوصسول للمطيعي بحاشية

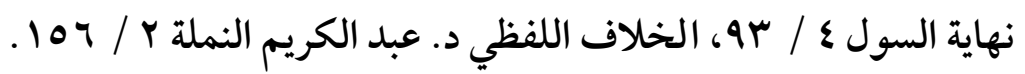




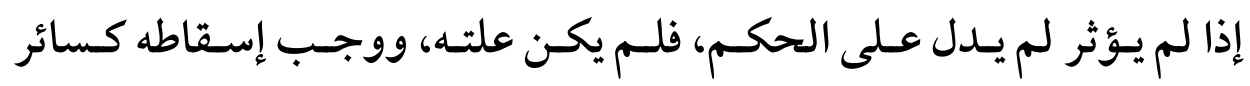
الأوصاف التي لا تحتاج إليها.

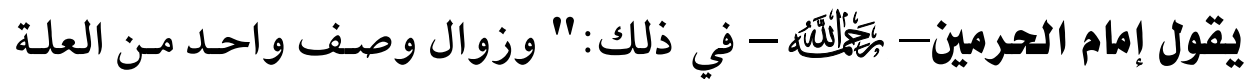

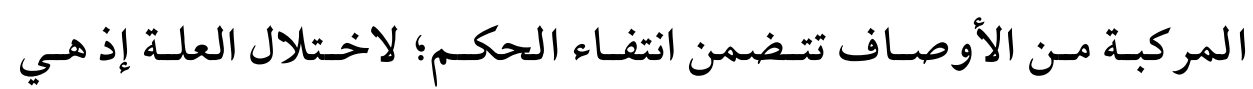
مر كبة، و شر طها تكامل أوصافها، فكان انتفاء الحكم محالاً على اختـلال

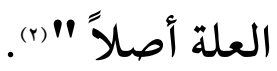

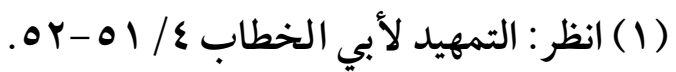

$$
\begin{aligned}
& \text { (Y) البرهان / / آT / }
\end{aligned}
$$




\section{المبحث الثاني \\ حكم تعدد العلل}

وفيه أربعة هطالب:

\section{الإطاب الأول}

\section{المذاهب في تعليل المكم الواحد بعلتين أو أكثر}

تحرير محل النـزاع في المسألة: اتفق الأصسوليون على جـواز تعليل الحكـم الواحد بعلل في كل صورة بعلة، واختلفوا في جـواز تعليله في صسورة واحـدة بعلتين أو أكثر معاً على مذاهب متعددة.

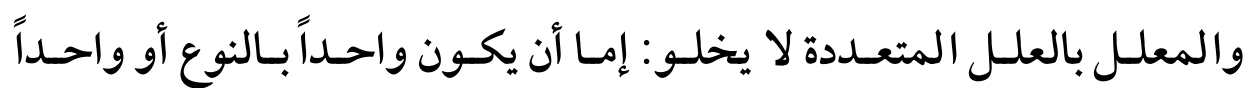
بالشخص "(1) فالواحـد بـالنوع يجـوز تعـدد علته بحسب تعـدد أشخاصسه بـلا

$$
\text { ( ) الواحد يطلق باعتبارات متعددة: }
$$

أحدها: الواحد بالجنس، وهو الصادق على أنواع مختلفة، كالحيوان، والجسم النامي ونحو ذلك. وثانيها : الواحد بالنوع وهو المقول لنوع واحـد تحته أصـناف، كالإنسان، والفرس

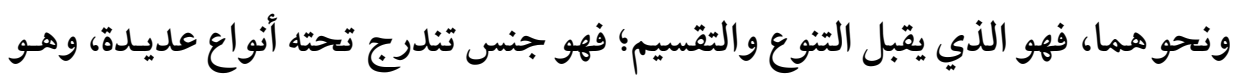
الكلي الذي تشترك فيه الأفراد، ويقبل التنوع. وثثالثها: الواحد بالصنف كالهندي والمصري.

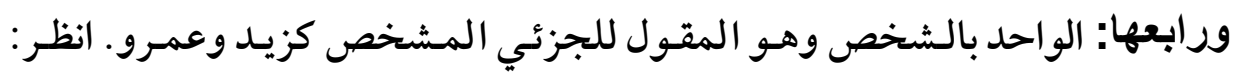

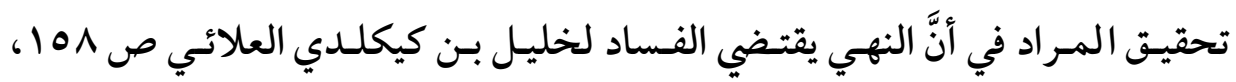


$(9 \cdot \varepsilon)$

تعلد العلل وأثره عند الأصولييز "دراسة أصولية تطبيقية"

خلاف عند الأصوليين، كتعليل قتل زيد بردته، وقتل عمرو بالقصاص، وقلية وقتل

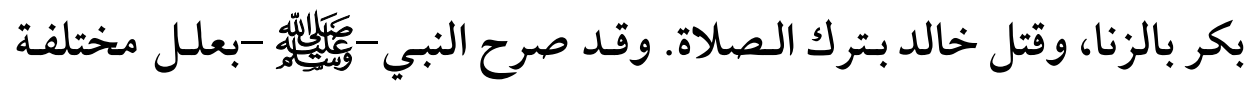

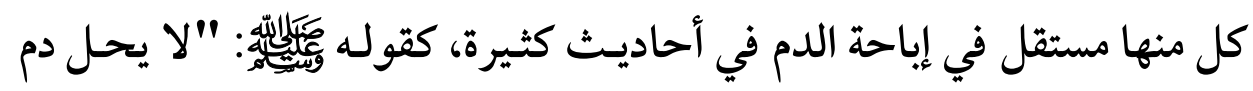

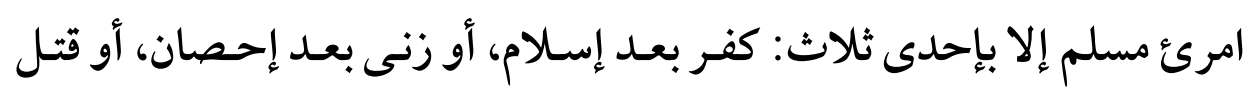

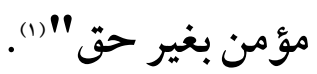

وأما الواحد بالثخص فلا خلاف عند العلماء في امتناع تعدد العلل العقلية فيه (()؛ لأنه بمعنى تأثير كل واحد، والمؤثرات على أثر واحد محال، وأما العلل الثرعية

الناشر : دار الكتب الثقافية - الكويت تحقيق: د. إبراهيم محمـد السلفيتي، التدمرية

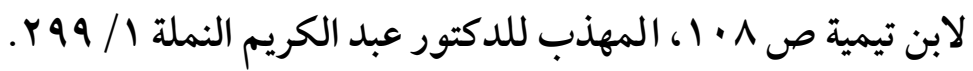

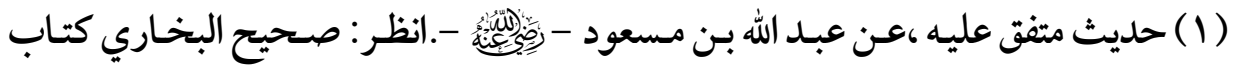

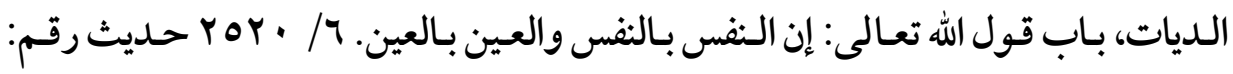

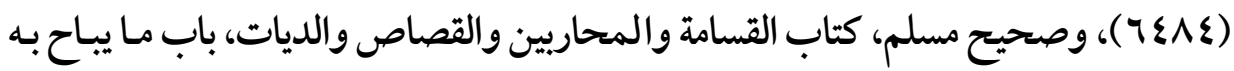

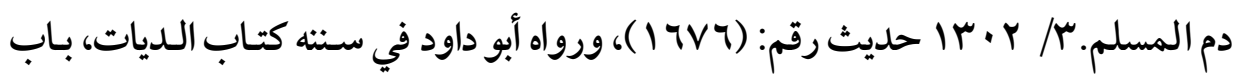

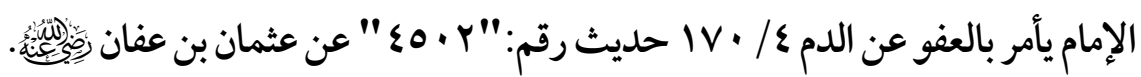

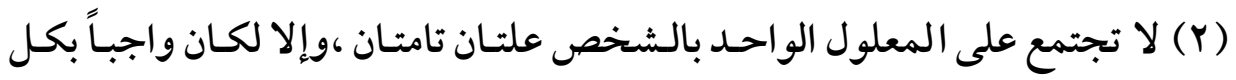

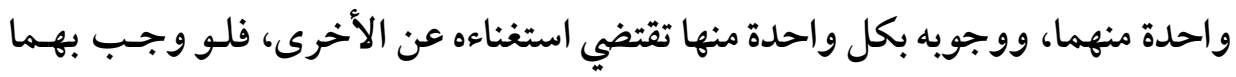

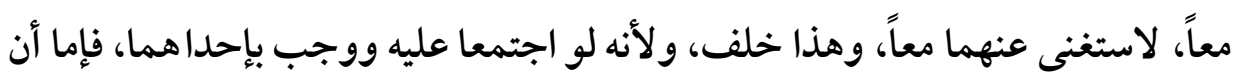
يكون لغيرها مدخل في العلية، أو لا يكون بأن كان مجموعهما هو العلة التامة، لا كل لاحل واحدة منهما ،وإن لم يكن فلم تجتمع عليه العلتان المستقلتان.

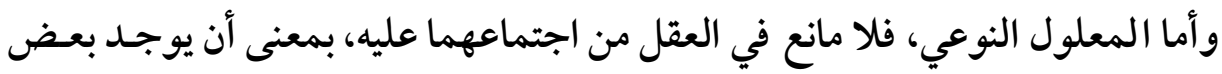
أفراده بعلة، وبعضها بعلة أخرى، كالحرارة، الني يعلل بعض جزئياتها بالنار، وبعضها 


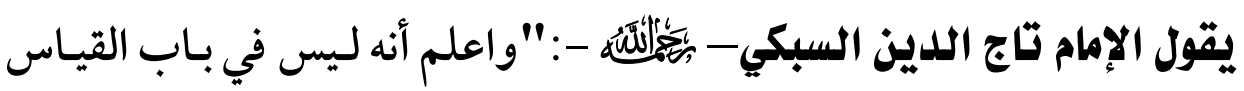
أشكل من الكلام على التعليل بعلتين، ونحسن نتوسط في إيـراده، فلا نسهب

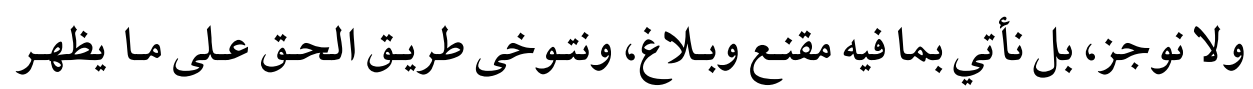

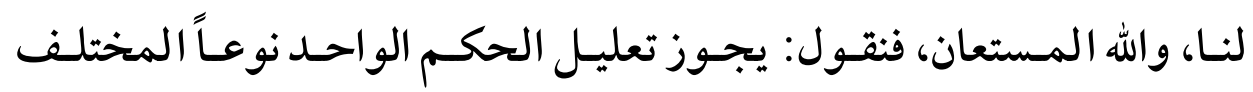

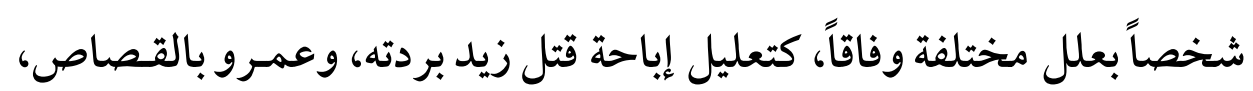
وخالد بالزنا بعد الإحصان، فلا يقع على صفة خاصـة وهي الرجم، ولاعبرة بإيماء من أومأ إلى جريان الخلاف هنا، وهذا في العلل الشرعية.

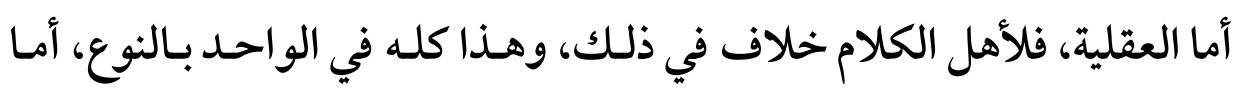
الواحد بالشخص، فلا خلاف في امتناع تعليله بعلل عقلية، وأما بعلل شرعية

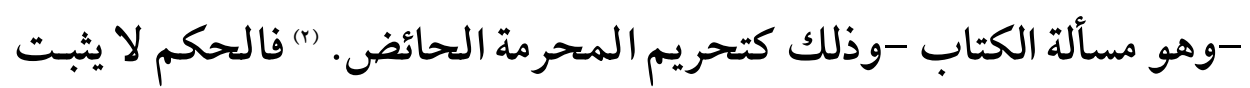
في العقل بأكثر مـن علة لتوقف كل مـنهما على الأخرى، بخـلاف الشرعية فيجوز.

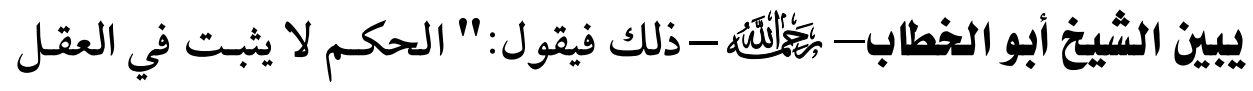
بأكثر من علة واحدة، فإذا جعل كل واحدد مـنهما علة الآخـر وقف كل واحـد

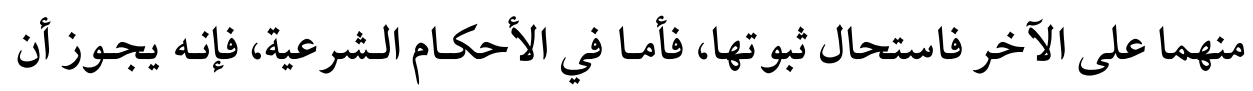

بالحركة، وبعضها بالشعاع. انظر : الجديد في الحكمة سعيد بن منصور بن كمونة ص

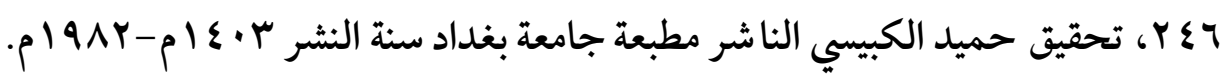

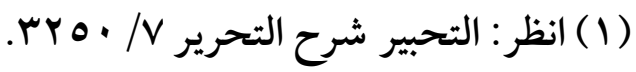

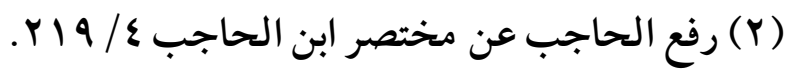




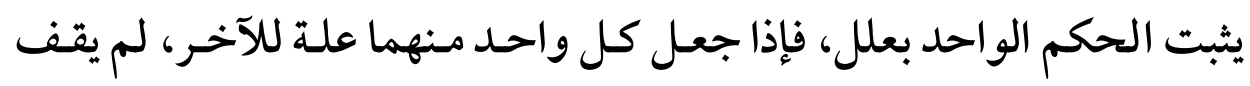

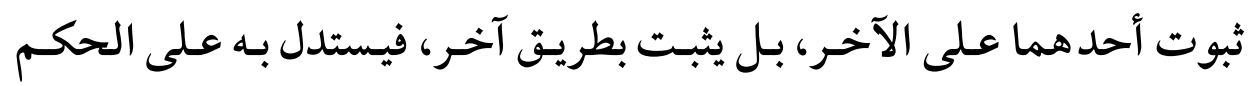

(1)" الآخر

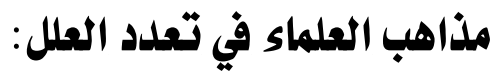

اختلف الأصوليون في هذه المسألة على مذاهب كثيرة أهمها ستة:

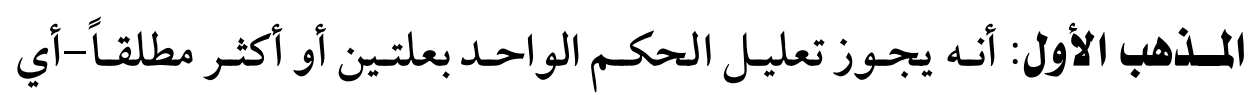

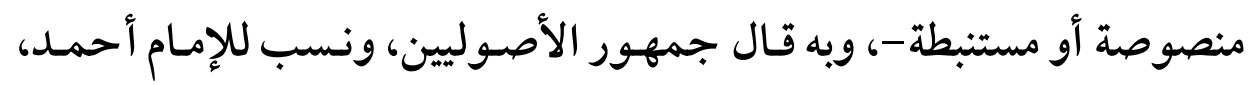
واختاره ابن الهمام من الحنفية، وابن الحاجب من المالكيـة، والغـزالي، وأبو وليو

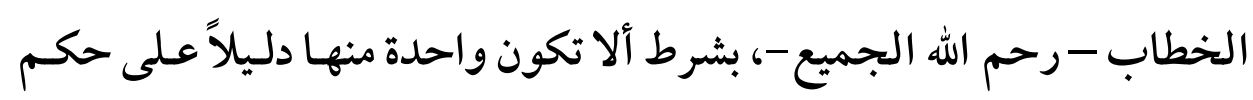
الأصل. (r) المذهب الثاني: أنه لا يجوز تعليل الحكم الواحد بعلتين أو أكثر مطلقاً، سواء

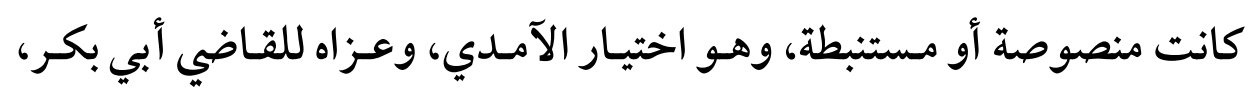
وإمام الحرمين، وهو مذهب السبكي، رحمهم الله جميعاً (r)

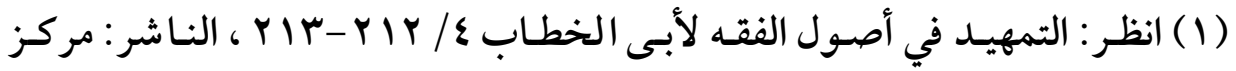

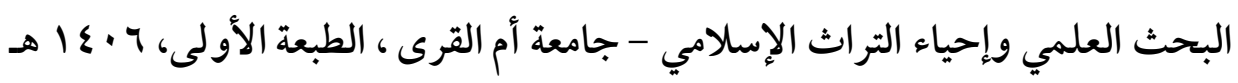
1910-

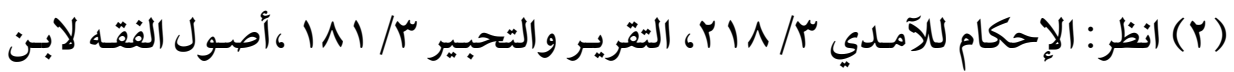

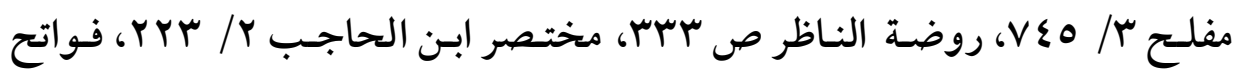

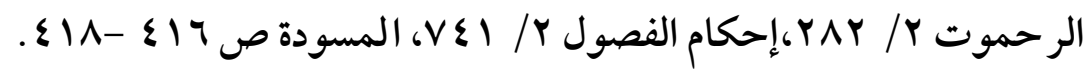

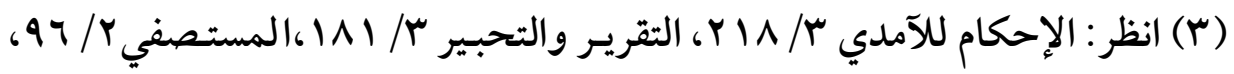

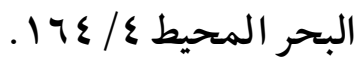


الملذهب الثالث: يجوز تعليل الحكـم الواحـد بعلتين أو أكثر في المنصوصة دون المستنبطة، وبه قال القاضي أبو بكر، وابـن فورك (1)، والرازي والقـرافي، وعزاه الآمدي للغزالي، رحم الله الجميع. (().

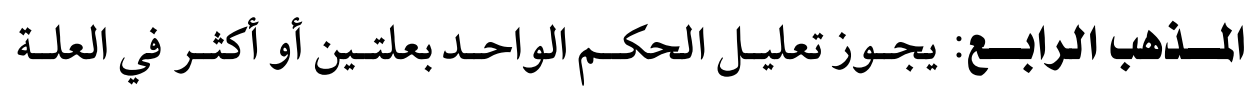

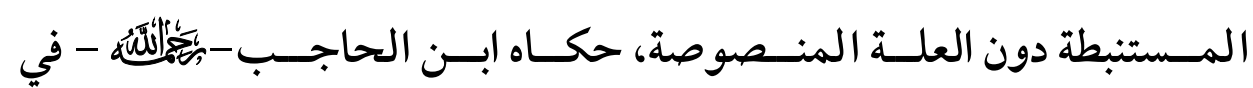

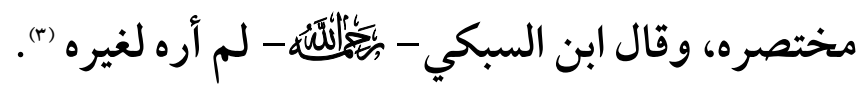

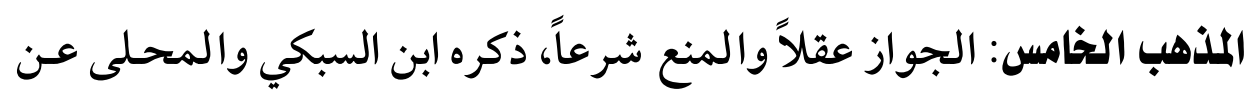
إمام الحرمين -ر حمهم الله جميعاً (s). المذهب السادس: أنه يجوز التعليل بعلتين متعـاقبتين، أي إحـداهما في وقـت،

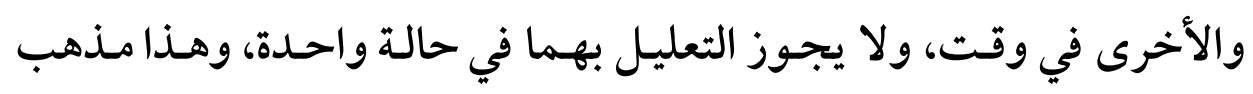

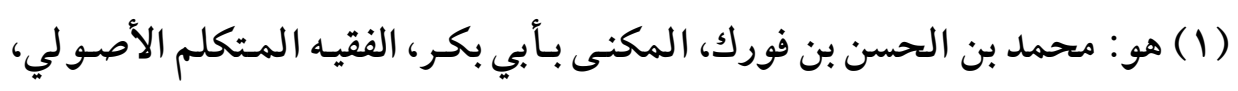

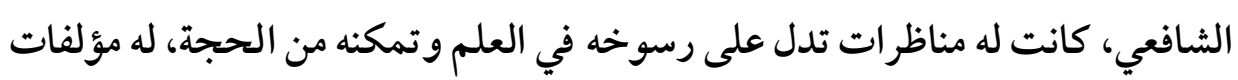

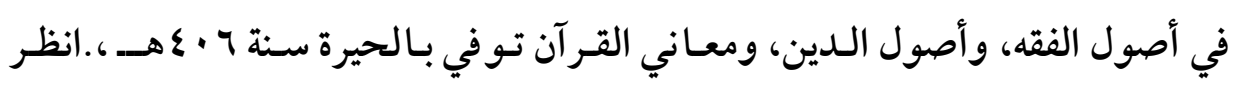

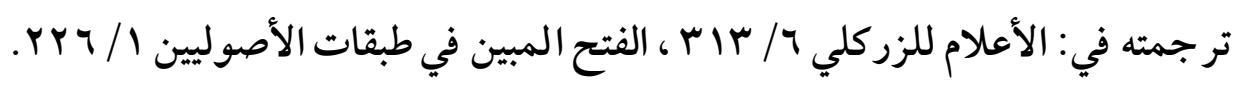

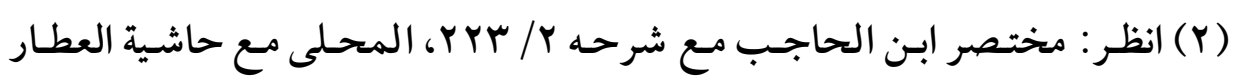

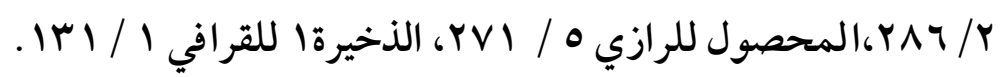

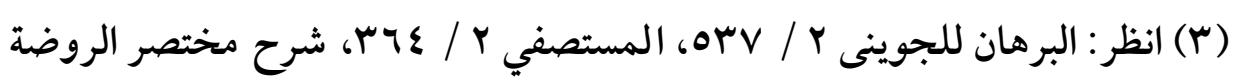

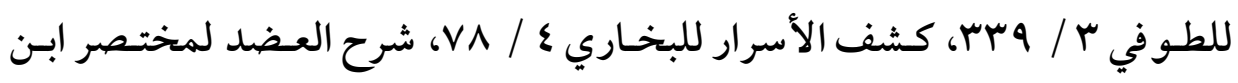

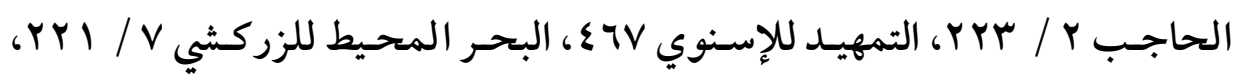

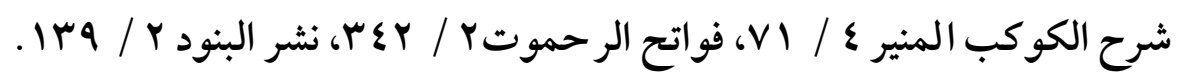

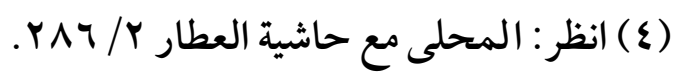




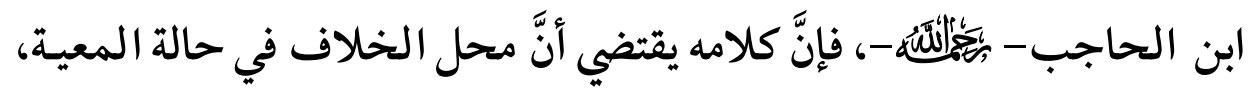

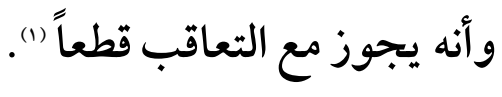

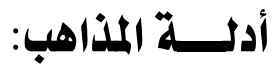
أولاً: أدلة المـذهب الأول: استـدل أصسحاب المـذهب الأول، القـائلون بجـواز تعدد العلل مطلقاً بما يأتي:

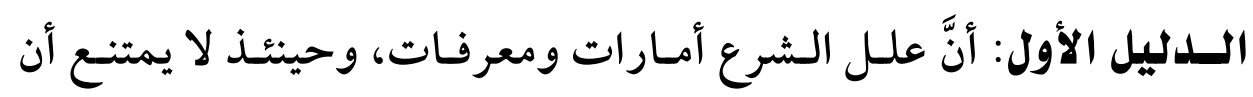
يجعل الشارع شيئين أو أكثر أمـارة على حكـم و احـد، كـاللمس والبـول علامة على نقض الوضوء، و تحريم الرضيعة على الشخص الو احد، لكونه

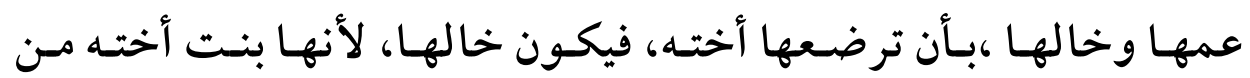
الرضاع، وترضعها زوجة أخيه بلبن أخيه، فيكون عمها، لأنها بنـت أخيـه

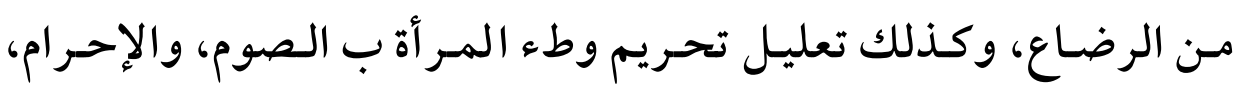

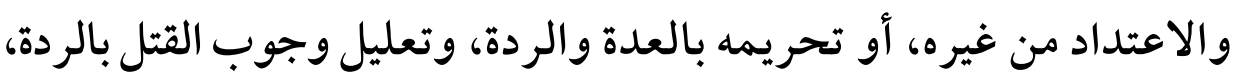
والمحاربة، و تحريم الاستجمار بالروث النجس لنجاسته، و وكونه طعـام

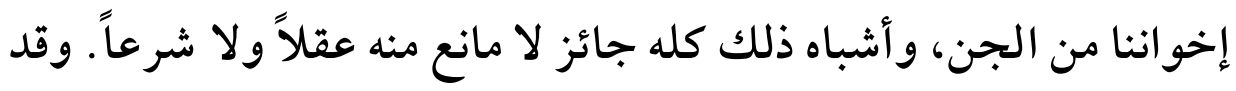
وقع شرعاً، فلا وجه لمنعه (r).

(1) انظر : الغيث الهامع ص ^؟ـ ـ ، المحلي على جمع الجوامع وحاشية البناني عليه

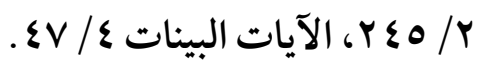

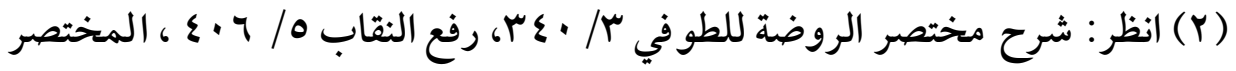

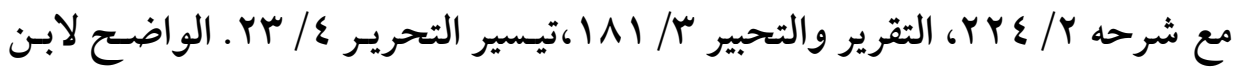

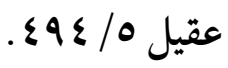




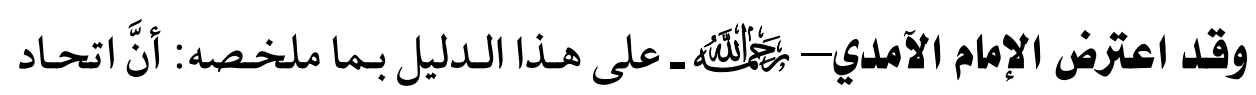

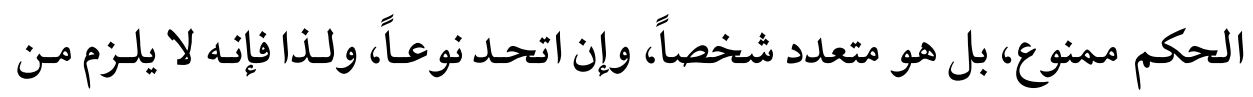

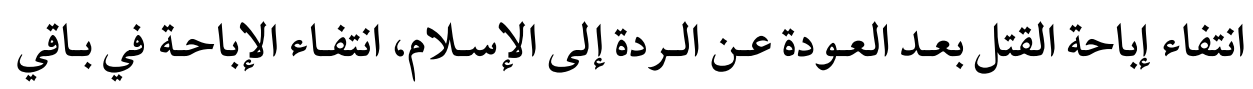

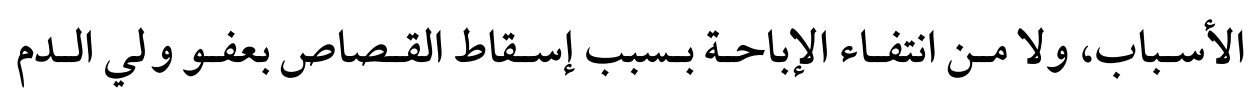

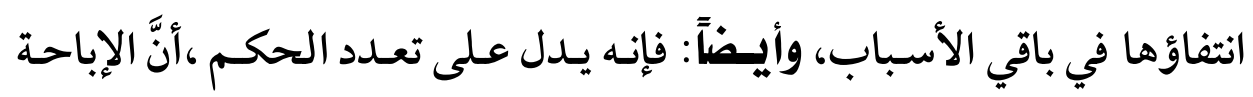

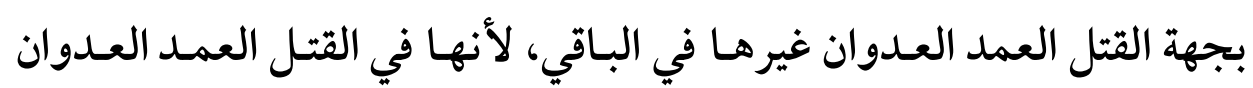
حق للآدمي خالص، ولذلك يمكن إسقاطه مطلقاً. وأما بجهة الزنا والردة فحق الله تعالى خالص دون ونى الآدمي، وذلك غير متصور

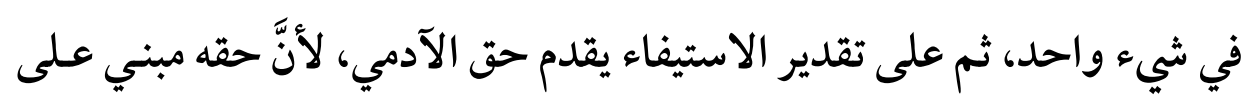

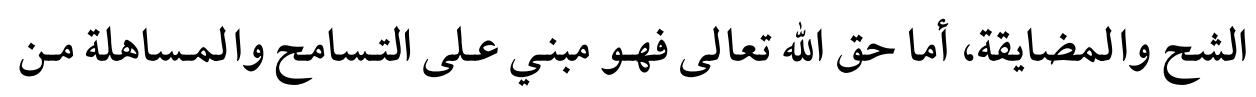
حيث أنَّ الآدمي يتضرر بغوات حقه دون الباري تعالى. الماتئ. وأما المسّ واللمس وباقي الأسباب في الأحداث المترتبة عليها متعـددة على لئل رأي لنا، وعلى هذا فلو نوى رفع حدث واحد منها، لارتفع الباقي، فأحكامها

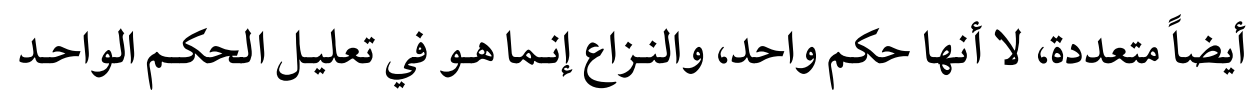

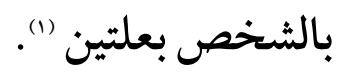
وأجيب عن هذا الاعتراض: بأَّهَ لو تعددت الأحكام لكـان تعـددها بالإضـافات

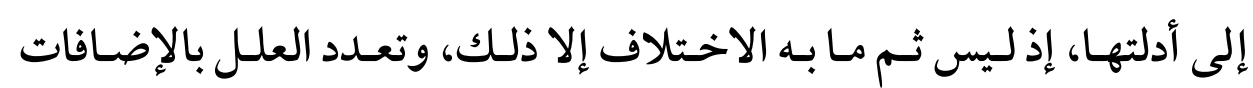

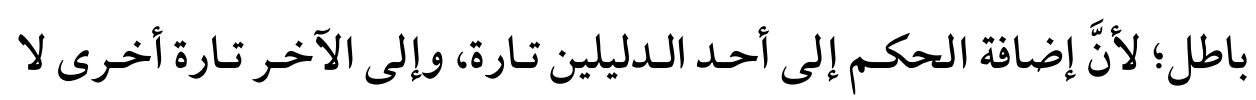
توجـب تعـدداً في ذات المـضاف، وهـو الحكـم كـما في الحـدث في المثـال 
(91.)

تعلد العلل وأثره عند الأصولييز "دراسة أصولية تطبيقية"

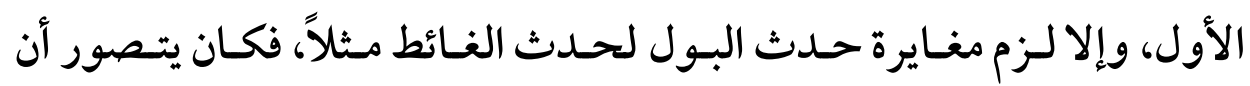

$$
\text { يرتفع أحد الأحداث بالوضوء الواحد ويبقى غيره "(1). }
$$

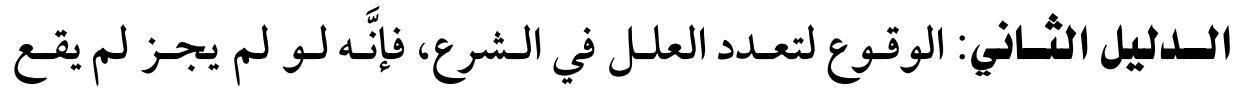

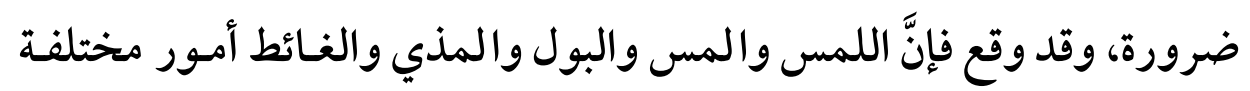

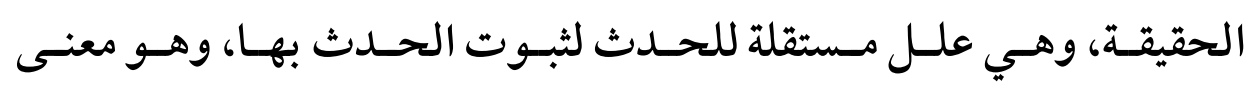
الاسـتقلال، وكـذلك القـصاص والـردة مختلفتــان، و همــا علتـان مستقلتان لثبوت جواز القتل بكل واحد منهما.

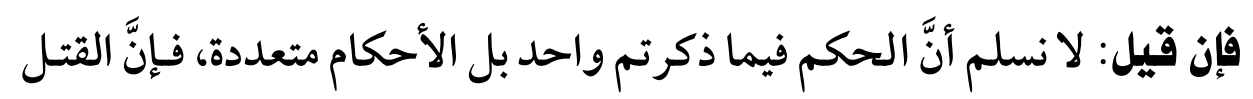
بالقصاص غير القتل بالردة، ولذلك ينتفي أحدهما ويبقى الآخر، كما ينتفي

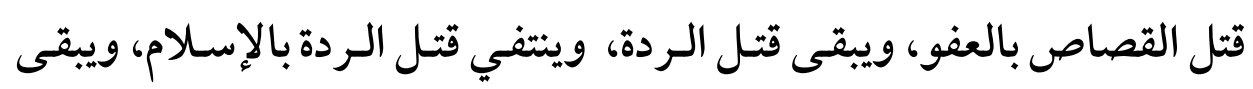

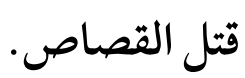
الجواب: أنه لو تعددت الأحكام لتعـددت بإضـافتها إلى الأدلة، إذ ليس ثَمََّّما

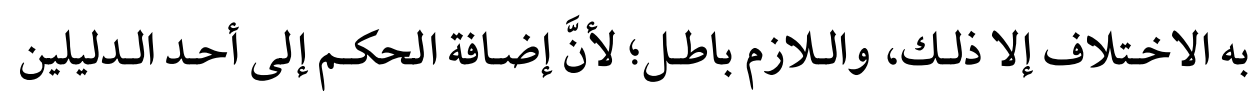

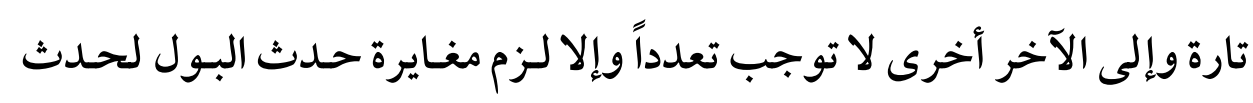

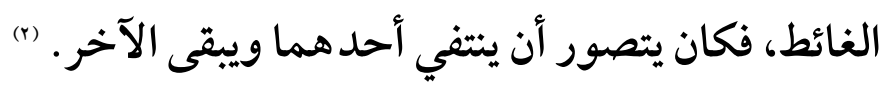

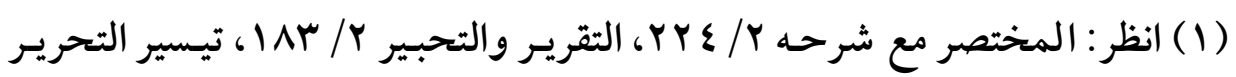

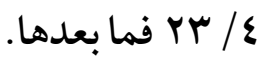

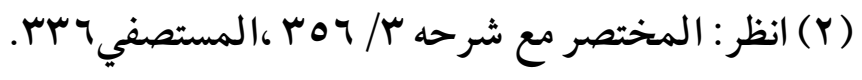


(911)

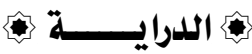

السدليل الثالـث: أنـه لـو امتنع تعـد العلل، لامتنع تعـد الأدلة؛ لأنَّ العلل

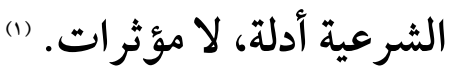
واعترض على ذلك: بأنَّ الأدلة الباعثة أخص مـن مطلق الأدلة، ولا يلزم مـن

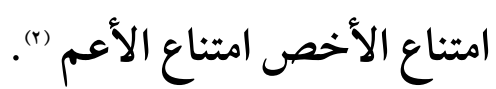
وأجيب عن ذلك: بأنَّ العلل الشرعية غير موجدة ولاعم عادية، وإنما هي أمارات

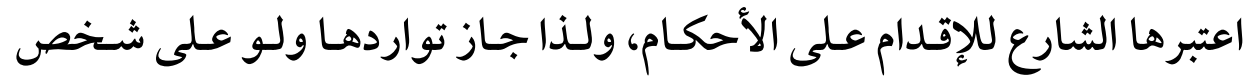

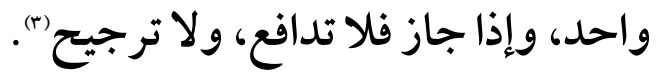

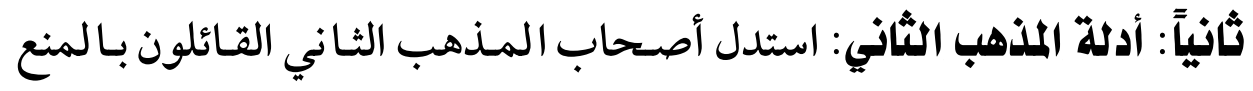

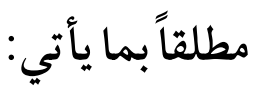
اللدليل الأول: أنَّ تعليل الحكم بعلتين أو أكثر يفضي إلى نقض العلة، وهو

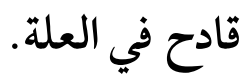

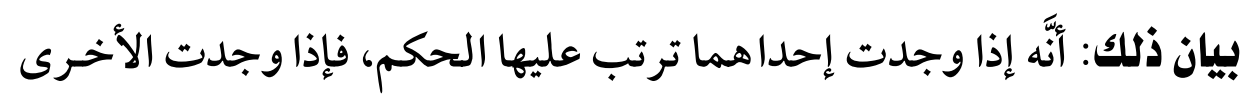

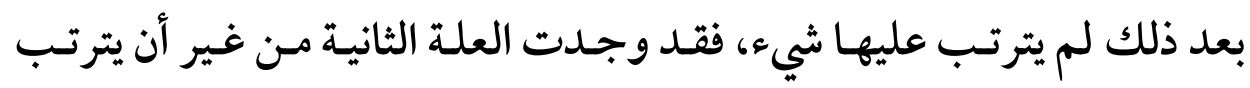

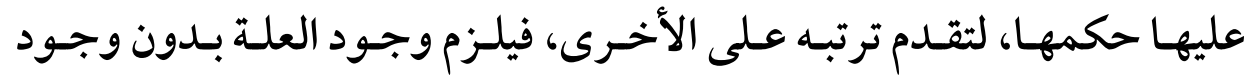
مقتضاها، وهو نقض للعلة.

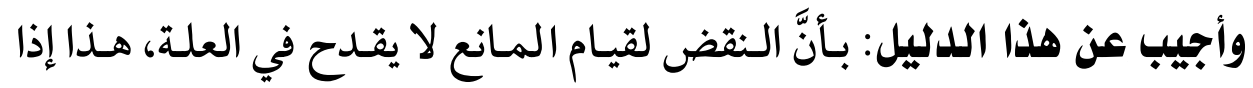

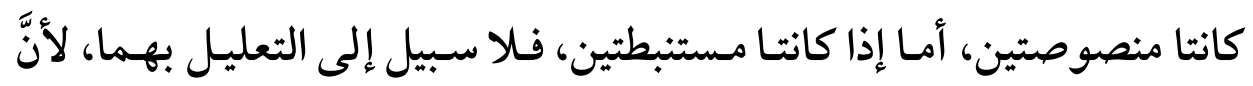

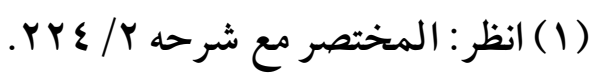

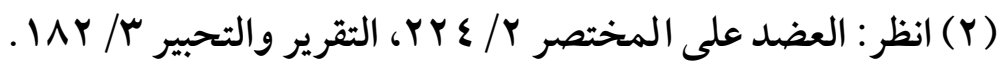

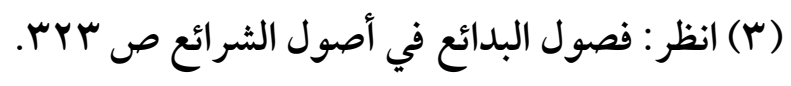


$(9 \mid r)$

تعدد العلل وأثره عند الأصولييي "دراسة أصولية تطبيقية"

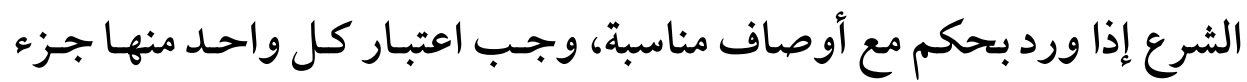

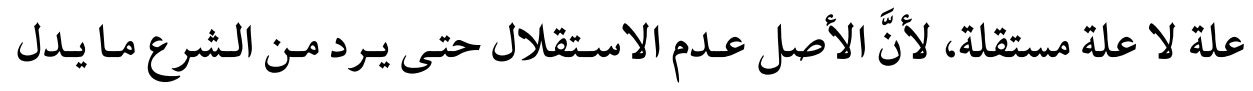
على استقلال واحد منها، فيستقل (1).

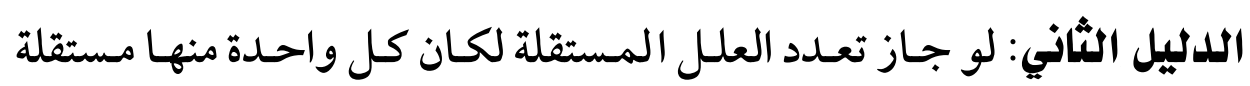

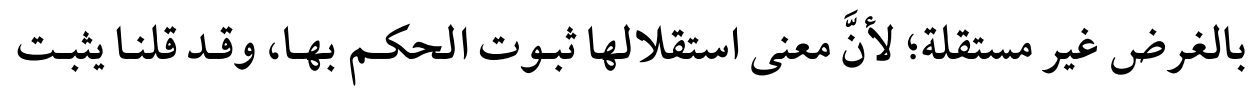

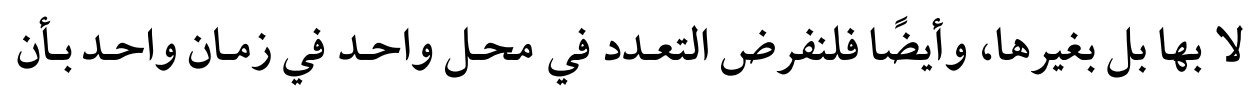

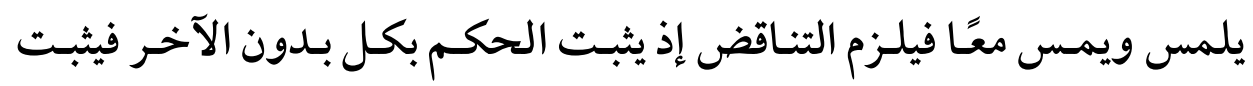
بهما ولا يثبت بهما. والجواب عن ذلك: لا نسلم لزوم الأمرين معًا، فإنَّ معنى استقلالها ليس ثبوت

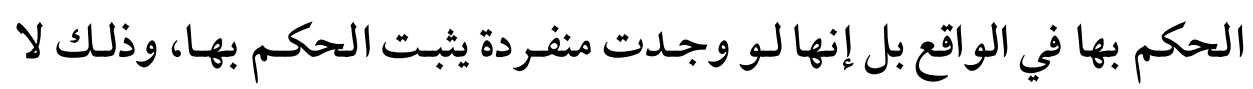

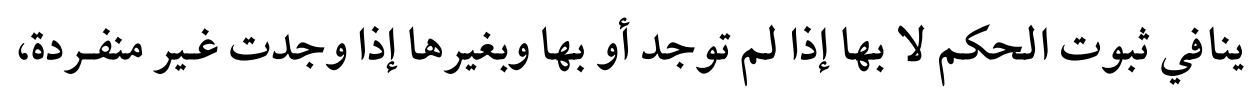

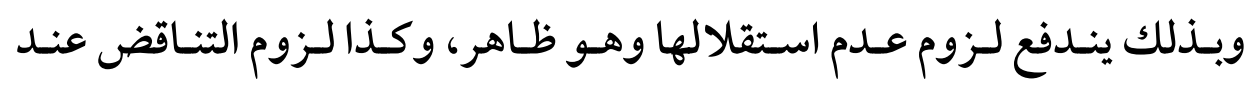

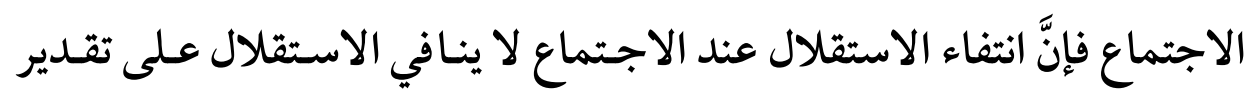

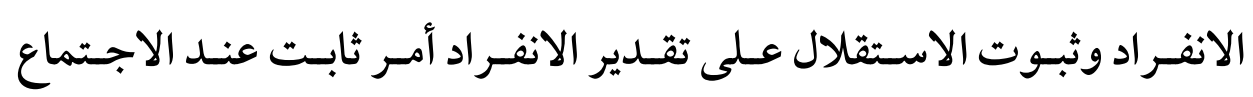
ونسميه بالاستقلال مجحازًا. (r)

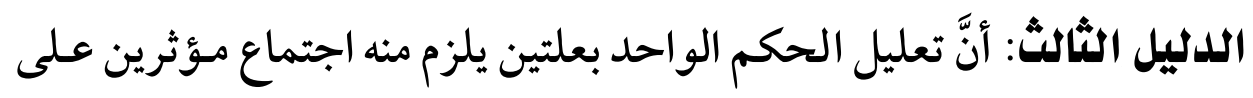

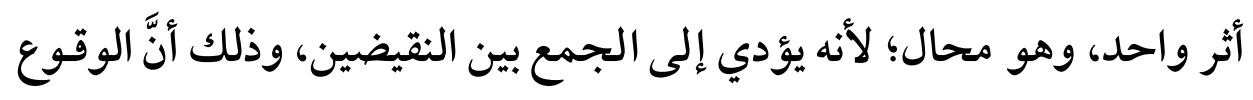

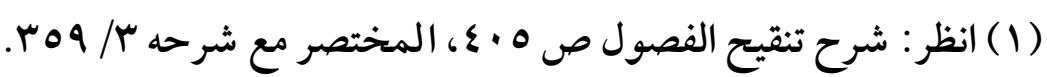

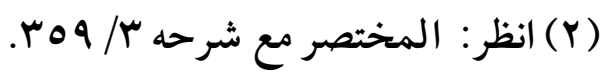


(qIY)

بأحـدهما سـبب في عـدم الوقوع بـالآخر، فلـو وقع بهـما للزم ألا يقع بهـما، وذلك جمع بين النقيضين، وهو محال.

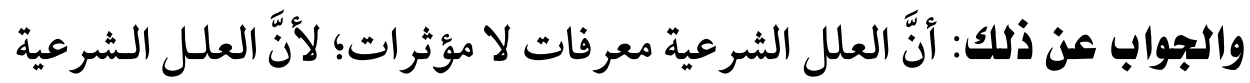

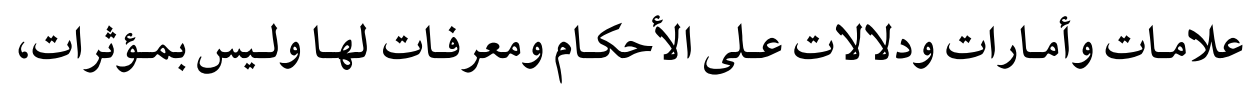
واجتماع معرفين أو معرفات على معرف واحـد جـائز، كما يعرف الله تبـارك وتعالى بكل جزء من أجزاء العالم "(1).

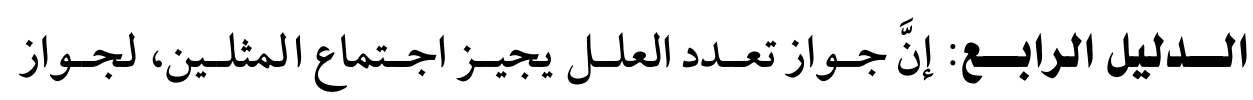

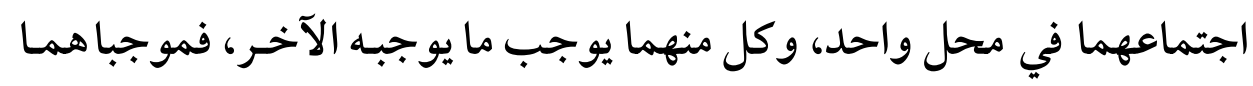

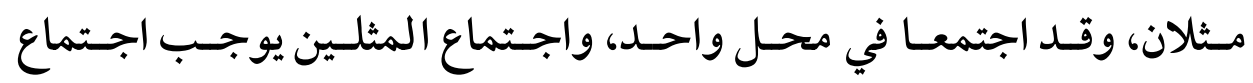

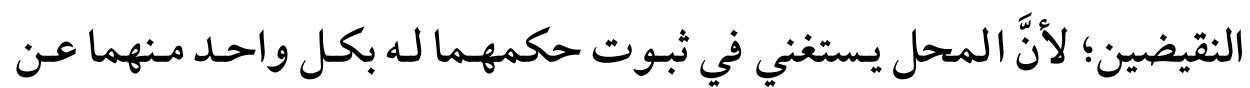

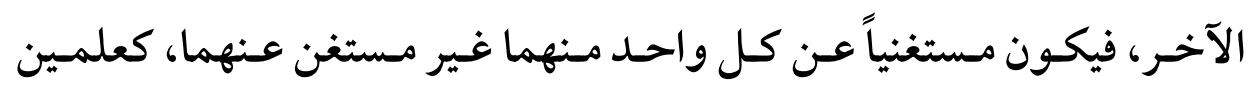

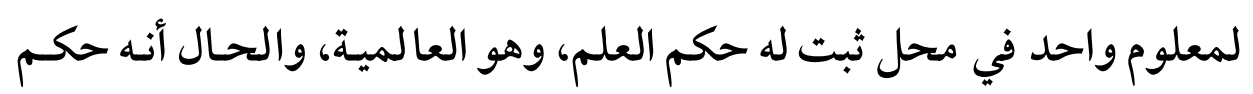

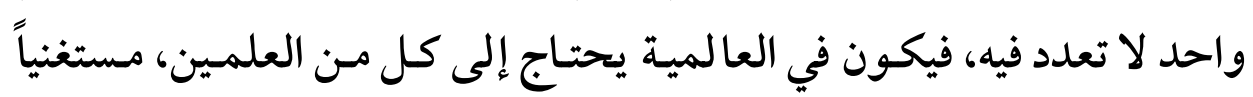
عنه بالآخر، فهذا لازمه مطلقاً.

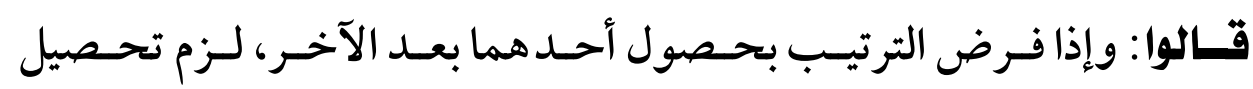
الحاصل أيضاً. وأجيب عز هذا الدليل: بأنه إنما يلزم ذلك لو كانـت العلة المستقلة عقليـة،

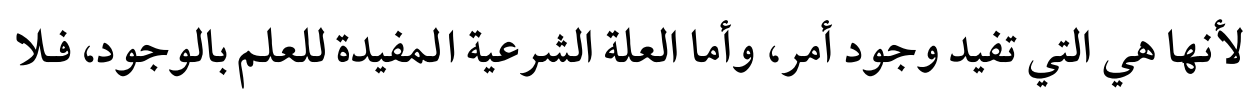
(1) انظر: رفع النقاب 0/ ج +ـ ، شرح تنقيح الفصول ص ه • ـ. 
(9)६) تعلد العلل وأثره عند الأصوليين "دراسة أصولية تطبيقية"

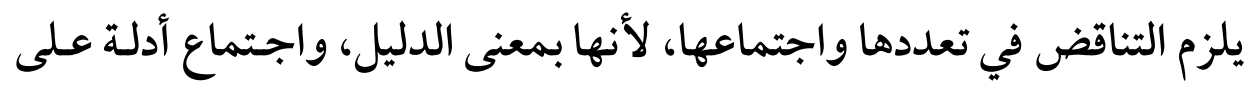
مدلول واحد جائز. وقل يجاب عنه أيضا بما سبق من أنه في حالة الاجتماع يكون كل جزءء علدة، والعلة المجموع، وعلى تقدير الاستقلال قد يتخلف عنه المعلول لمانع هو

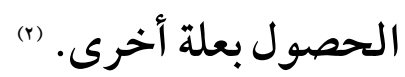
الــليل الخـامس: اشـتغال الأئمهـة بـالترجيح في علـل الربـا أهي: الطعـم، أو الكيل، أو القوت، يدل على استقلال كل بالعلية؛ إذلو جاز تعدد العلل لقـالوا به، ولم يشتغلوا بالترجيح لتعيين واحدة منها، ونفي ما سواها (م).

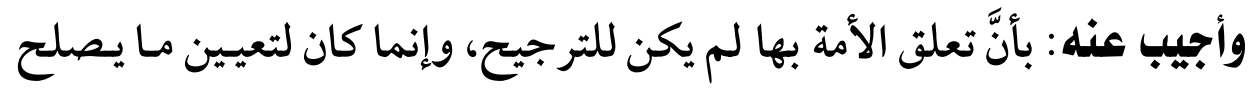
علة مستقلة، وإبطال التعليل بما سواها، وعلى فرض التسليم، فالإجماع على بلى

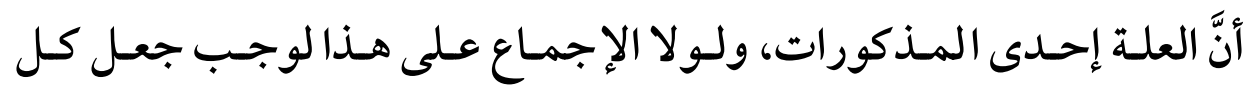

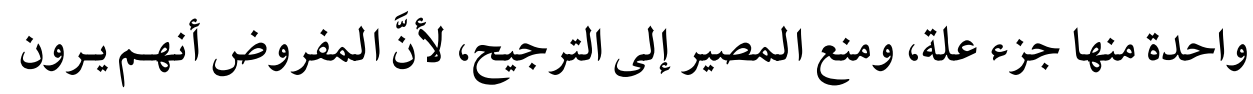

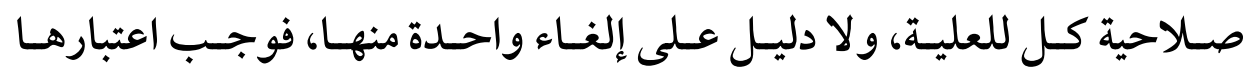

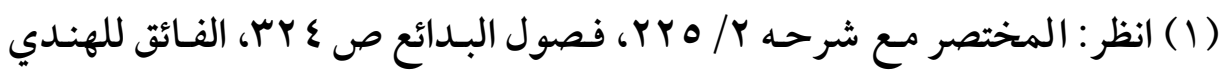
$. r 9 \Lambda / r$

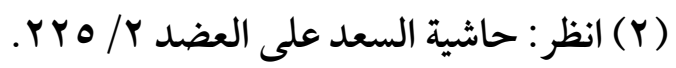

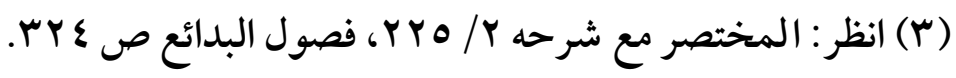


$(910)$

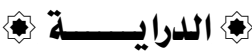

جميعاً، وذلك قول بالجزئية، ليكون الكل داخلاً في العلية، لا سيما عند عـدم

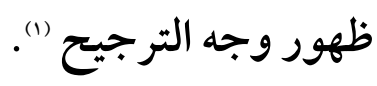

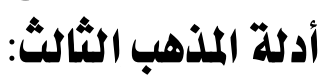

استدل أصحاب المذهب الثالث القائلون بجواز التعدد في العلة المنصوصة

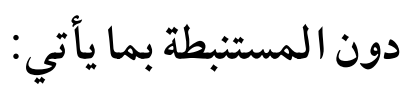

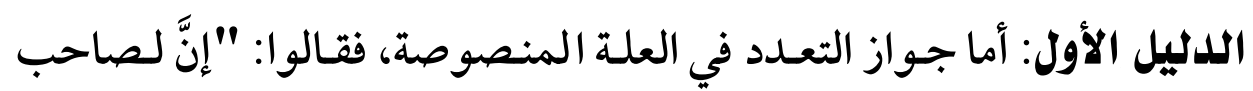

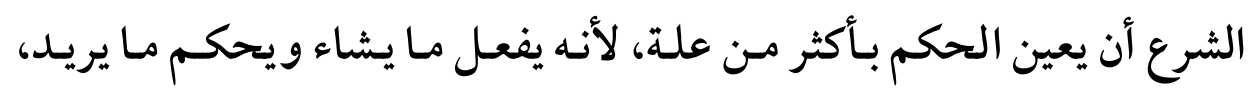

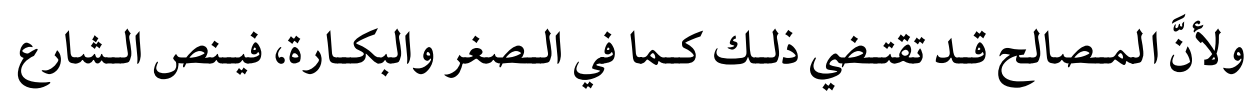

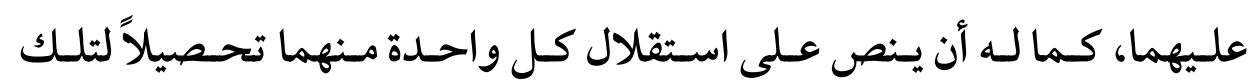
المصلحة وتكثيراً لها" (r).

الدليل الثاني: وأما منع التعدد في العلة المستنبطة فقالوا:

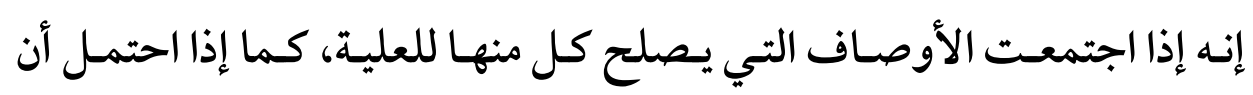

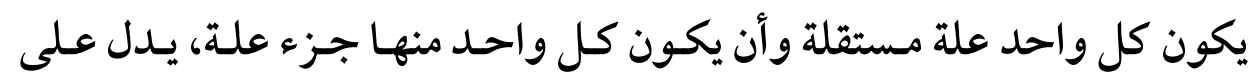

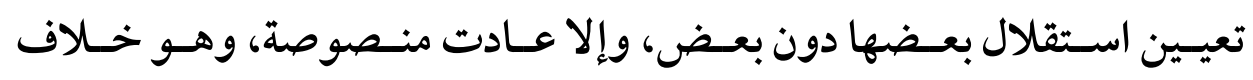

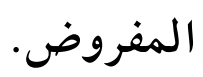

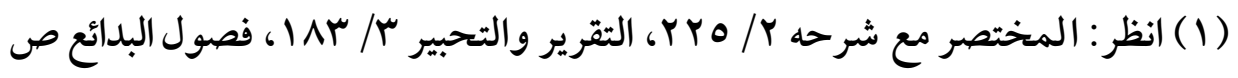
.MY

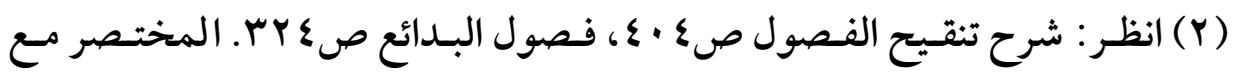

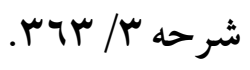


$(9 \mid 7)$

تعدد العلل وأثره عند الأصولييي "دراسة أصولية تطبيقية"

وأجيب عنه: بمنع التحكم، لإمكان استنباط الاستقلال بالعقل، وذلك أنه كما

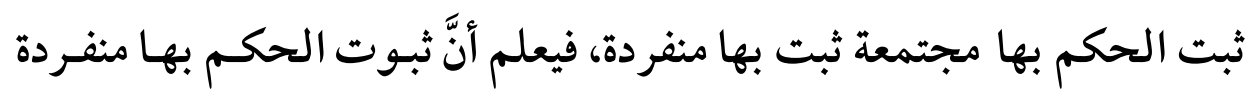

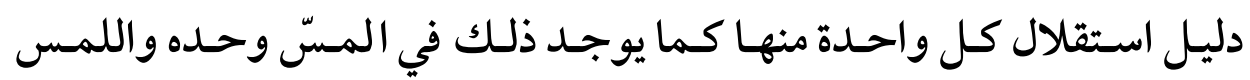
وحده في محلين، ويوجد بثبوت الحـدث معهـما، فعلم أنَّ كل واحسد مـنهما

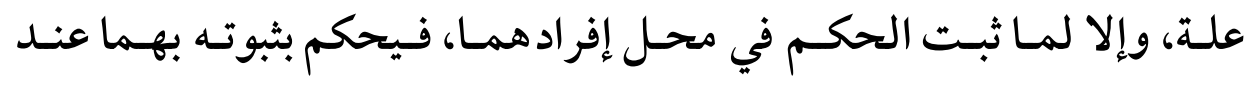

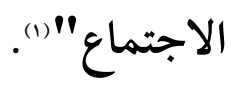

Y - أنه إن أعطى فتيهاً فقيراً قريبـاً، احتمل أن يكـون كل واحـد منها علة، أو المجمـوع، أو مجمـوع اثنـين، وهـي متنافيسة، إذ قولنـا: الـداعي إلى الإعطـاء

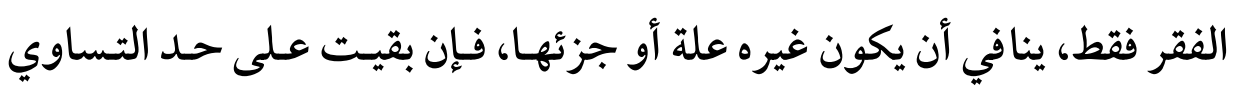
امتنع ظن علية شيء منها وإلا فالر اجح علة.

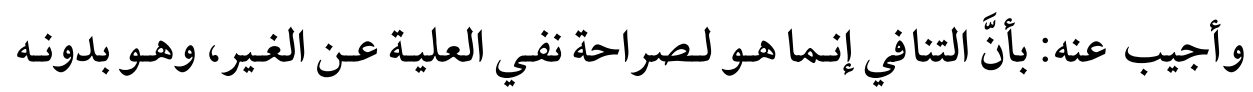

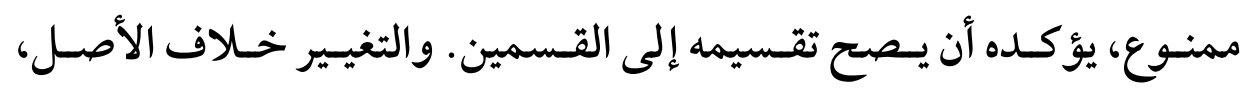
والتكاذب بين الاحتمالين لو سلم فحيث عرف المقصود، سلمناه، لكنه نزاع في معنى اللفظ، لا أنه لا يجوز ذلك.

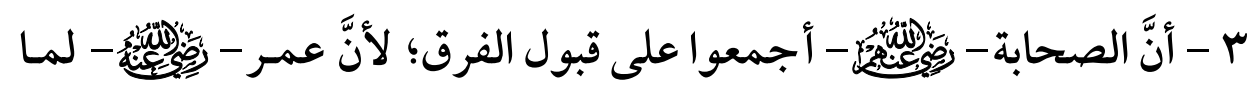

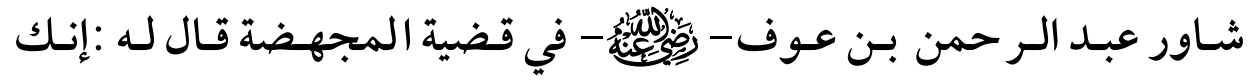

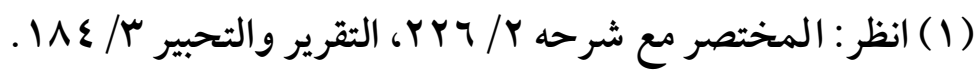

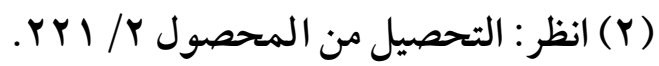

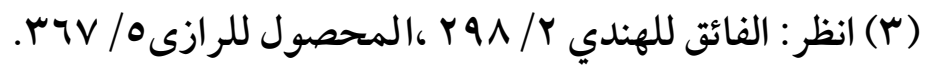


(qIV)

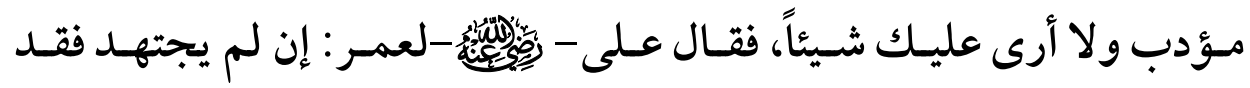
غشك، وإن اجتهد فقد أخطأ أرى عليك الغرة. (1)

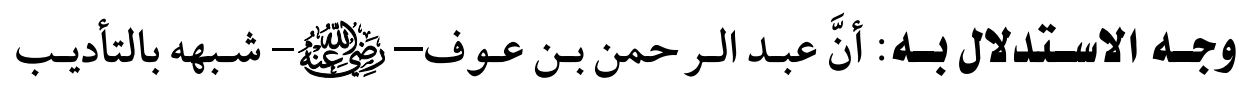

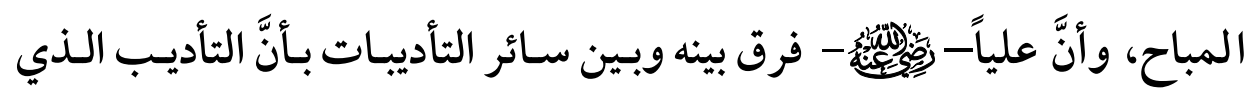
يكون من جنس التعزيزات لا تجوز فيه المبالغـة المنتهية إلى حـد الإتلاف، وذلك يـدل عـلى إجمـاعهم عـلى قبـول الفـرق، وهـو يقـــح في جـواز تعليل الحكم الواحد بعلتين مستنبطتين. (r)

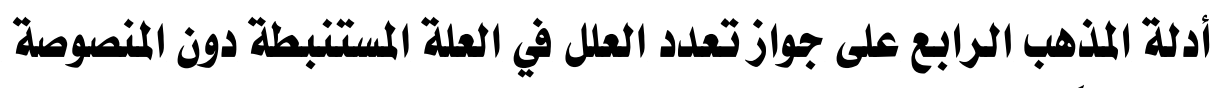

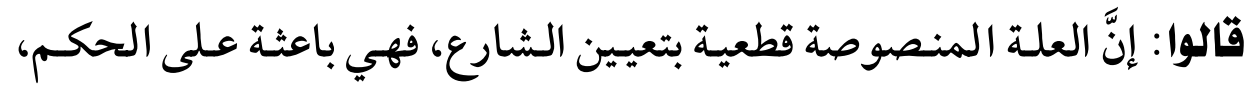

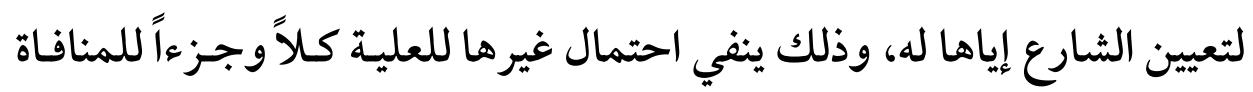

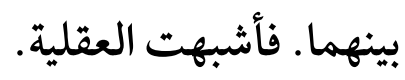

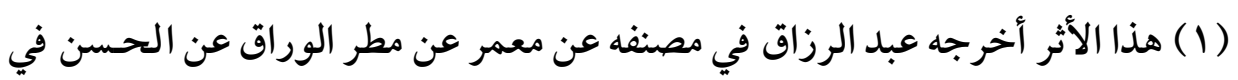

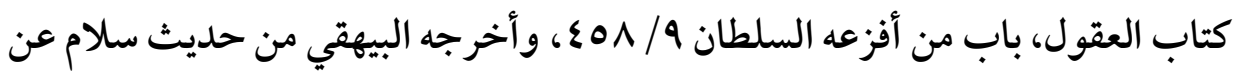

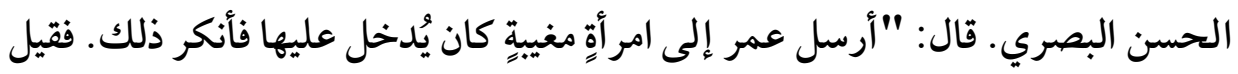

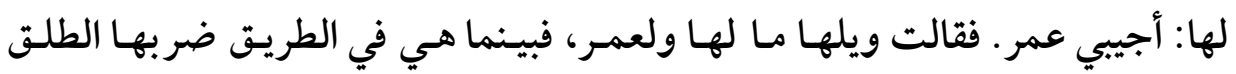

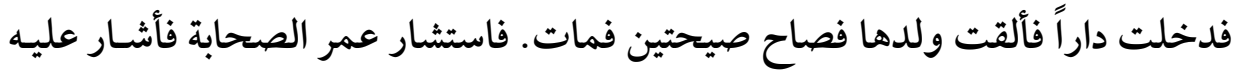

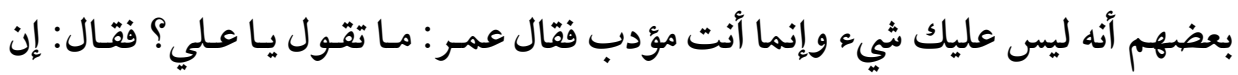

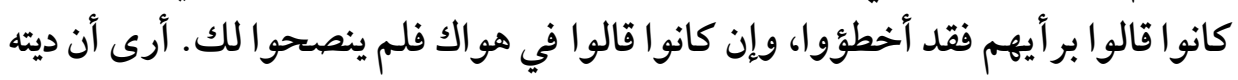

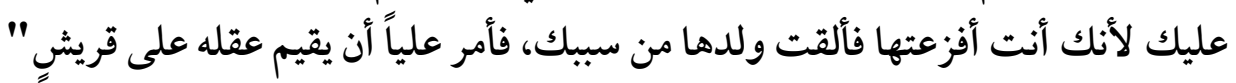

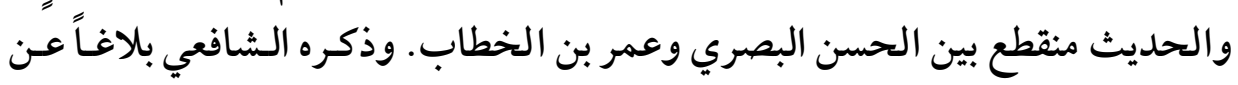

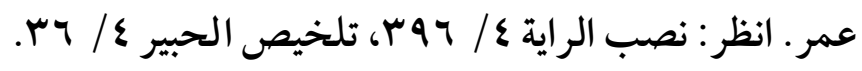

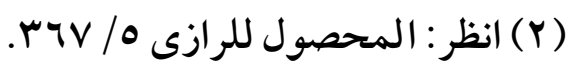


(9)1)

تعدد العلل وأثره عند الأصولييز "دراسة أصولية تطبيقية"

والعلة المستنبطة ظنيـة، فجـاز أن تتعـدد كالأمـارات، ولوجـود سـبيها في كل

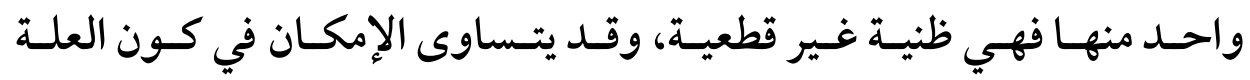

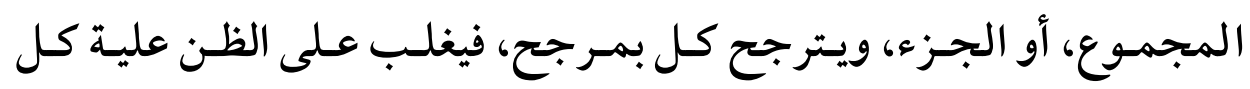
منهما، فيجب أتباعه.

وأجيب عنه: بمنع القطع في العلة المنصوصة المراده بهاعا السمعية، لجواز أن

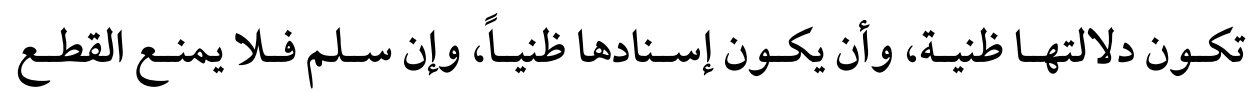

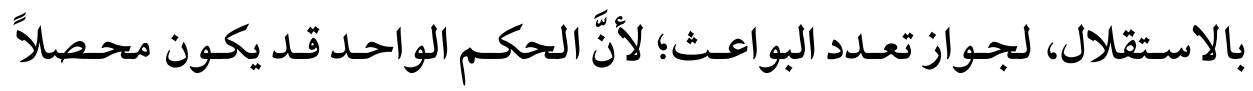
لمصالح متعددة، دافعاً لمفاسد مختلفة (1).

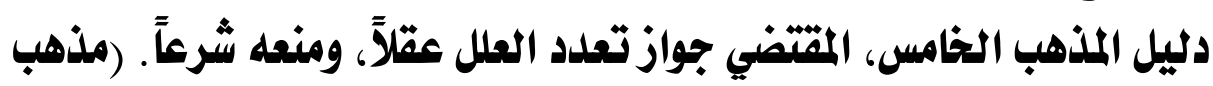

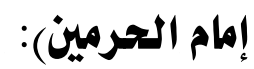

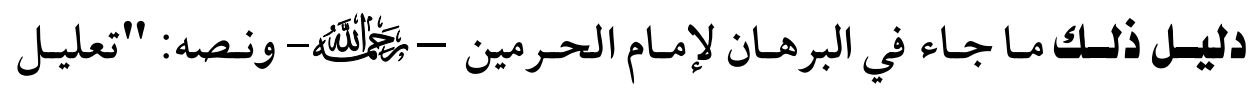

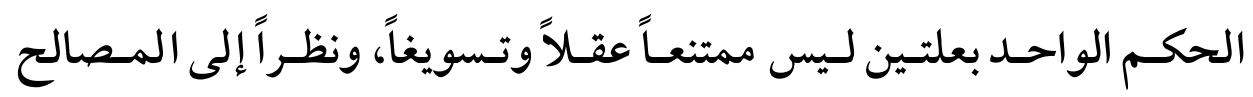

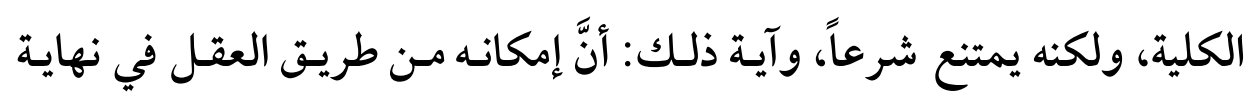

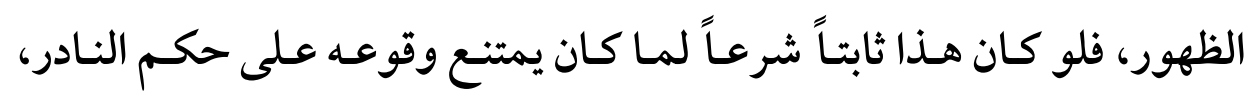

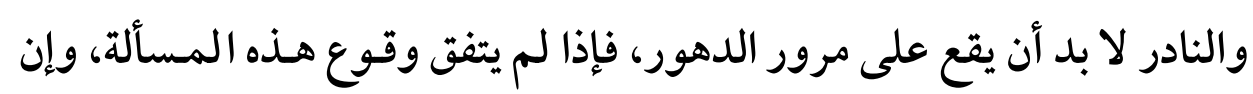

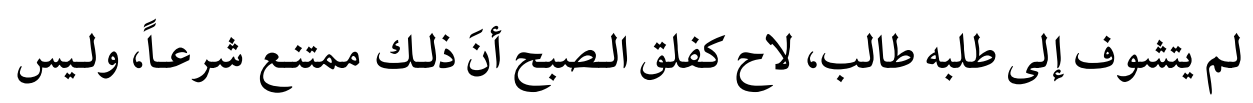

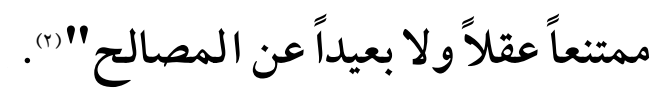

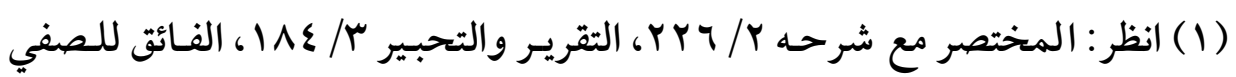

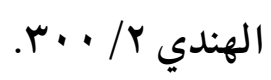

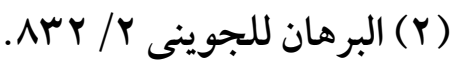


(919)

ثم ادعى لتصحيح دعـواه عـدم وقوعـه فيما تقـدم ذكره مـن أسباب الحـدث

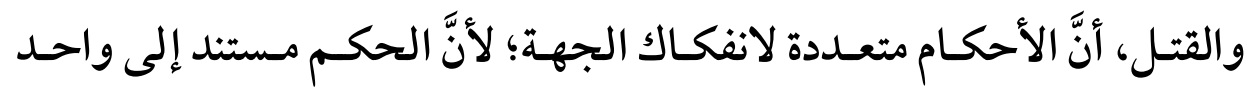

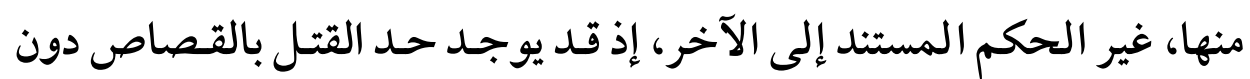

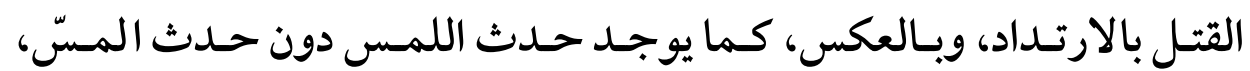

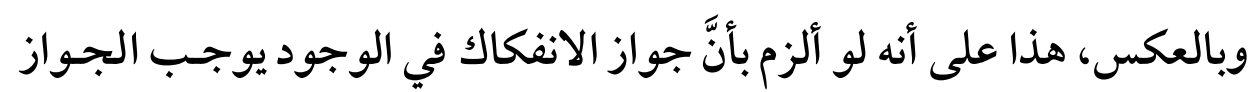

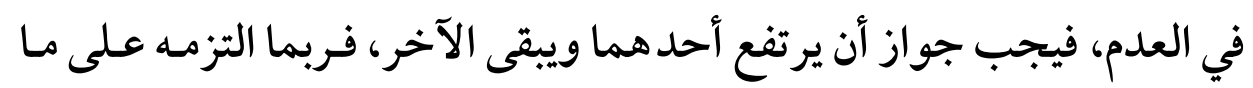
ذهب إليه البعض من أنه إذا نوى أحد أحداثه لم يرتفع الباقي" (1).

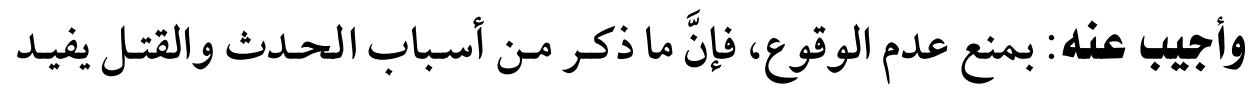

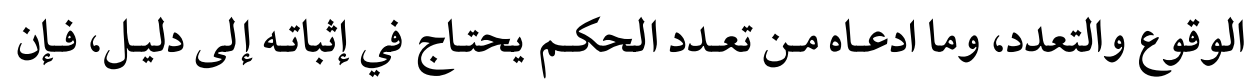

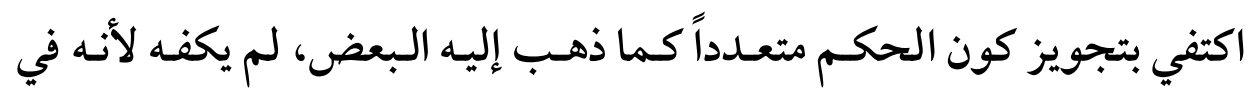

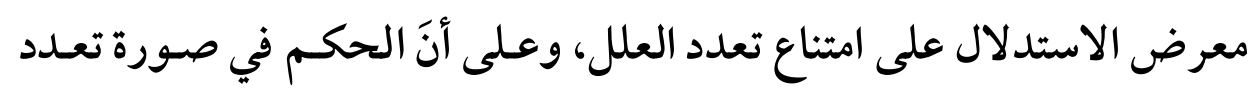
العلل متعدد. وما ادعاه من أنه قد ينتفي أحـد الحكمين، ويبقى الآخـر، فقـــ تقـدم اقتصاره على القتل لتحقق تعدد المستحق على ما تقدم توجيهه، وانتفـاء الانفكاك في

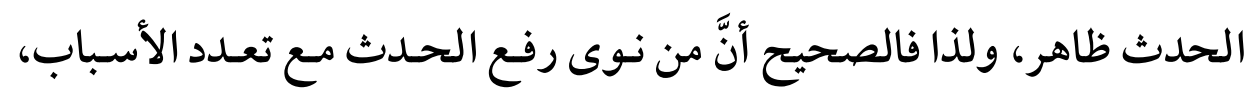
صح وضوؤه (r) دليل المذهب السادس: على أنه يجوز التعليل بعلتين متعاقبتين، ولا يجوز التعليل بهما في حالة واحدة.

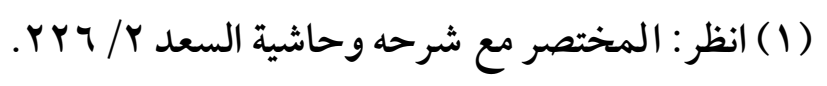

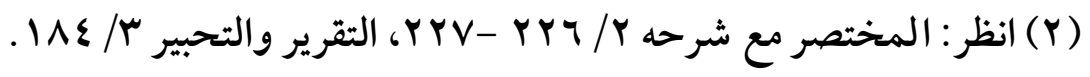


(qr•)

تعلد العلل وأثره عند الأصوليين "دراسة أصولية تطبيقية"

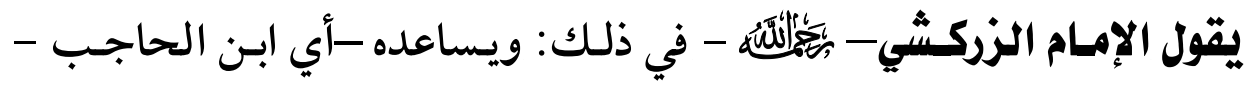
تمثيل الغزالي بمن لمس وبال في وقت واحد، وبه صرح الآمدي في جـواب

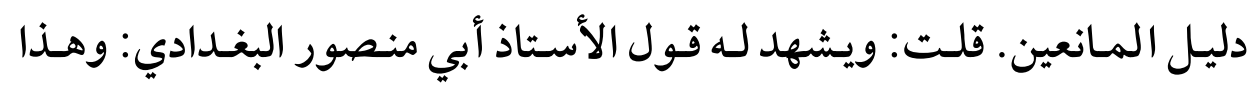
النـوع مـن العلـل ضربـان متقارنــة ومتعاقبـة، فالمتعاقبـة تجتمـع في إيجـاب

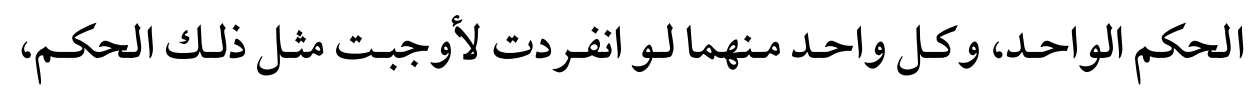

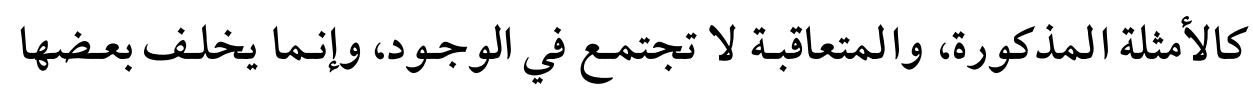
بعضاً في حكم واحد، وذلك مثل دم الحيض يوجب تحريم الوطء، ثم يرتفع الدم ويبقى تحريم الوطء، لأجل عدم الطهارة. (1). وأجيب عن ذلك: بأَّهَ يلزم من شموله حالة التعاقـب، أن يكـون أحسداً مـن الأمـة

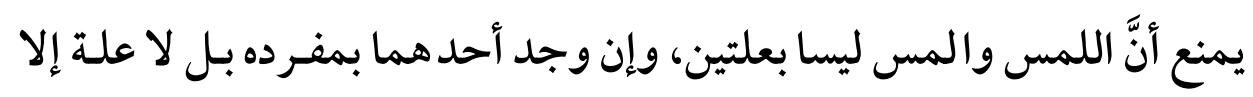

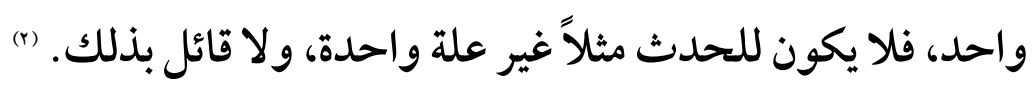

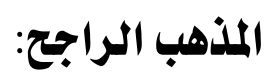
الذي يترجح عندي هو ما ذهب إليه الجمهور من جواز تعـدد العلل الشرعية

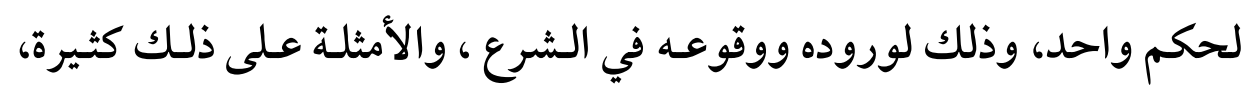
كما في البـول والغـائط والمسّ واللمس، وكـما في وجـوب الغسل بالتقـاء

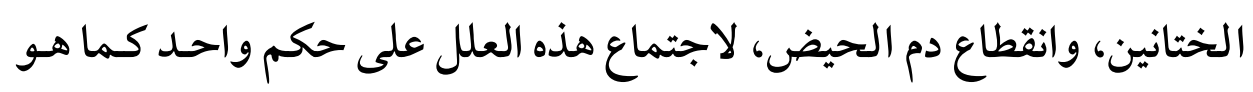

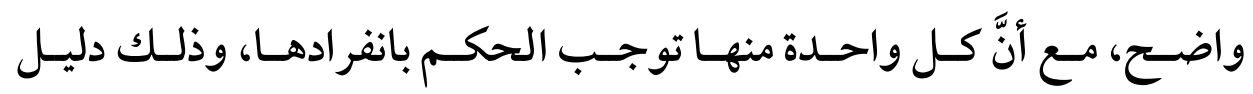
الاستقلال، ولأنـه لـو نـوى رفع أحـد هـذه الأحـداث لارتفـع البـاقي، كـما في

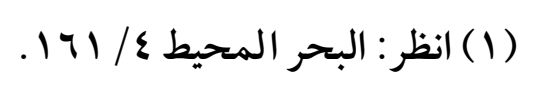

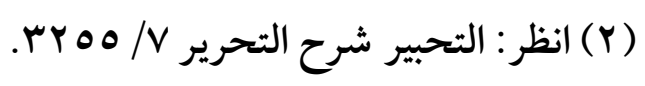


اجتماع الأدلة السمعية على المدلول الواحد مع حصوله بأحدها عند تخلف غيره.

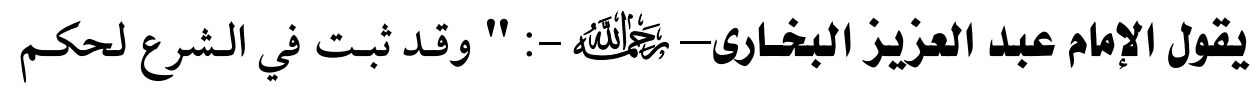
واحــ علل متعـددة، كـالنوم والإغـماء، وخـروج النجاسـة مـن السبيلين ومسن غـيرهم لانتقـاض الطهارة وكـالبيع والهبـة والـصدقة والمسيراث والاسـتيلاء للملك وكالردة والكفر المفضي إلى المحاربـة والبغي والزنا بعـد الإحصان

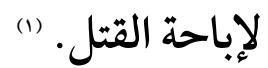

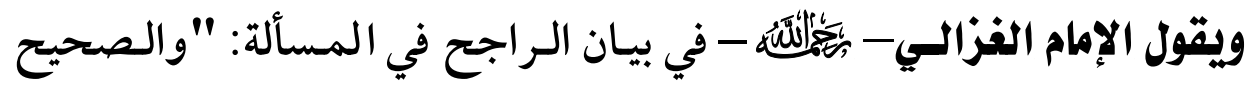

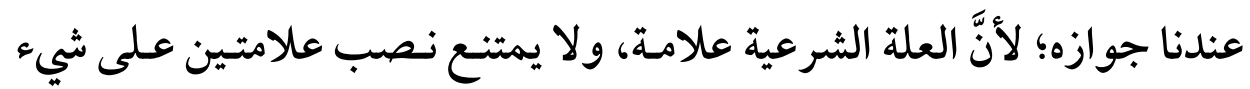
واحد، وإنما يمتنع هذا في العلل العقلية ")

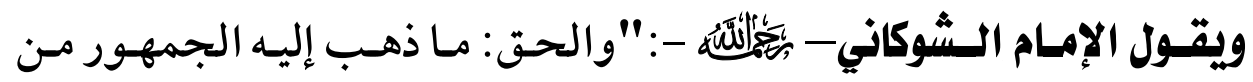

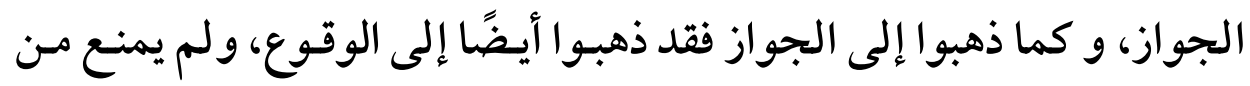
ذلك عقل ولا شرع 'ان.

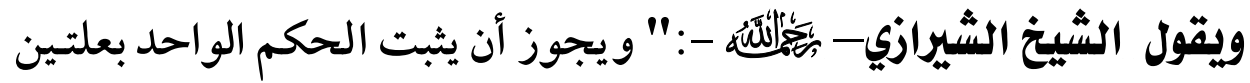

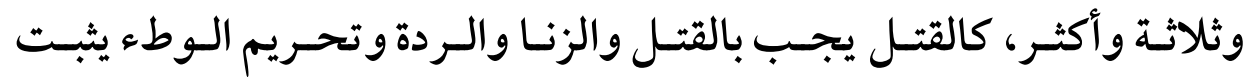
بالحيض والإحر ام والصوم والاعتكاف والعدة. ل)

$$
\begin{aligned}
& \text { (1) كثف الأسرار للبخاري / ع ع. } \\
& \text { (Y) المستصفي Y / צrr } \\
& \text { (Y) إرشاد الفحول / / 11 11. } \\
& \text { ( ) اللمع للشيرازي ص ه • } 1 .
\end{aligned}
$$


(arr)

تعدد العلل وأثره عند الأصولييي "دراسة أصولية تطبيقية"

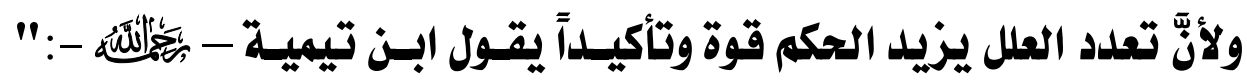

ومن يقول بتعليل الحكم الواحد بعلتين لا ينازع في أنه إذا اجتمـع علتان كـان

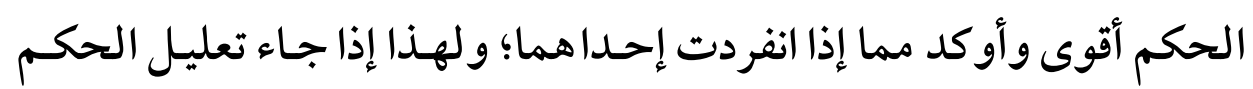

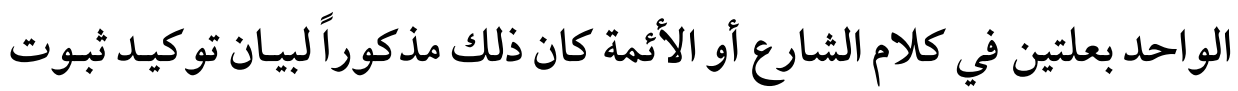

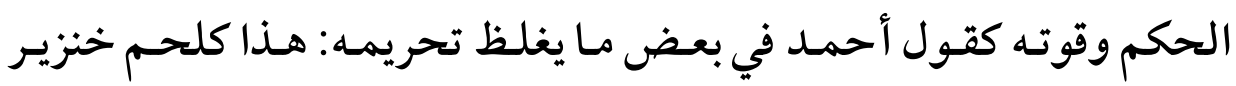
ميت فإنه ذكر ذلك لتغليظ التحريم وتقويته" (1) فئه نوع الخلاف في المسالة: الخلاف في هـذه المسألة خـلاف معنوي عند جمهـور العلماء، وهنـاك مـن يرى أنَّ الخلاف لفظي. فـي المسبودة: والخـلاف في ذلك -أي في تعـدد العلل - لفظي قريـب، فيإنَّ أحداً لا يمنع قيام وصفين كل منهما لو انفرد لاستقل بالحكم، لكن نقول هـ هـل فيل

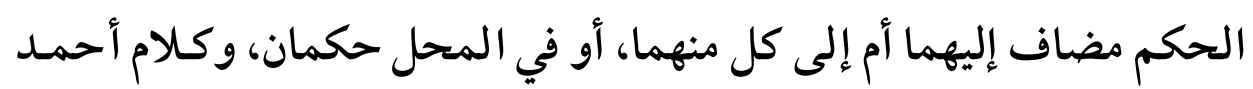

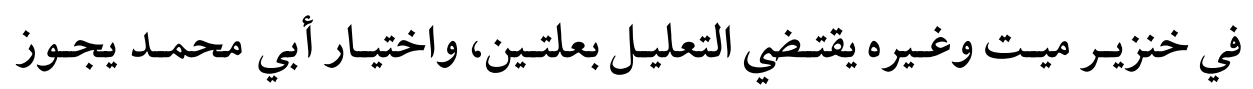

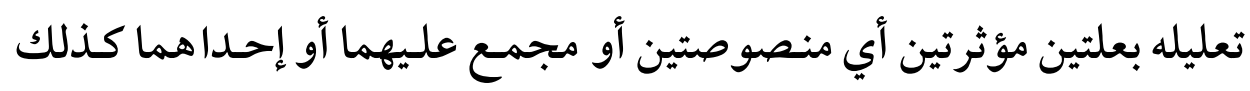

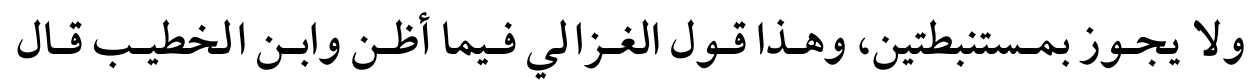
والعكس عندنا يجب إذا كانت العلة واحدة وأما مع تعددها فلا يجب. قلت: وقول أبي بكر عبد العزيز في مسألة الأحداث إذا نـوى أحسدهما يقتضي

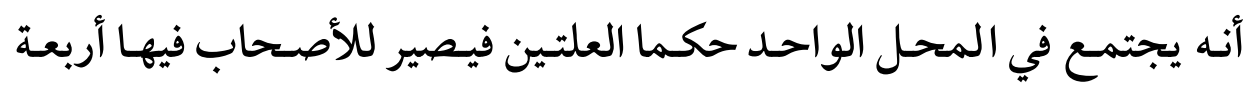

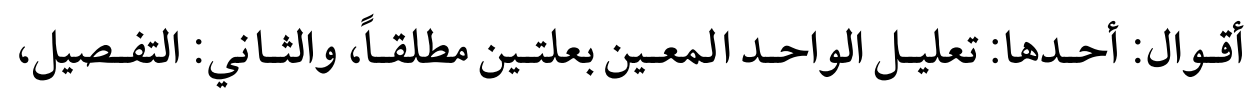


والثالث: أن يجتمـع في المحل الواحـد حكما همـا معـا، ومـن قـال هـذا قـال

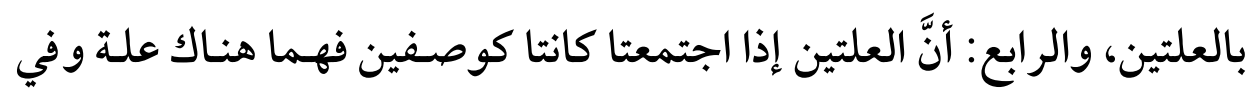

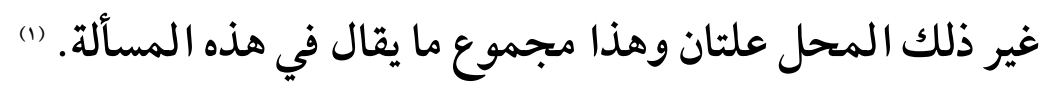

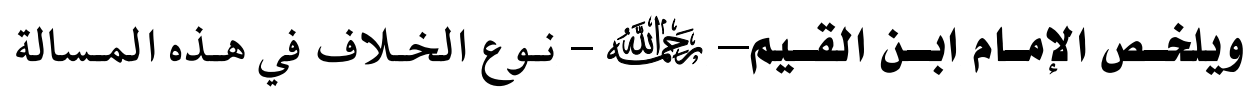

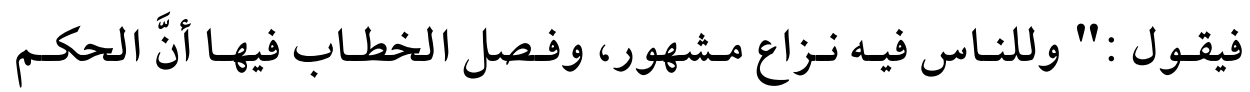

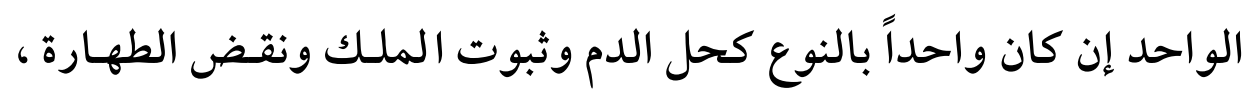

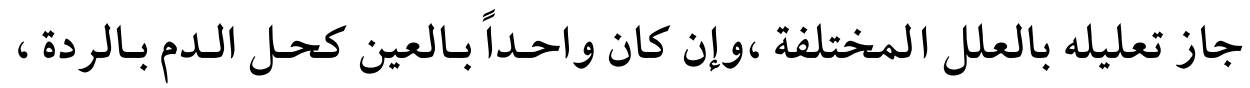

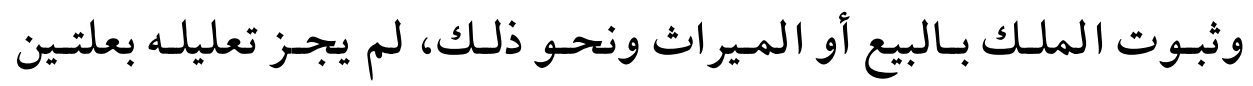

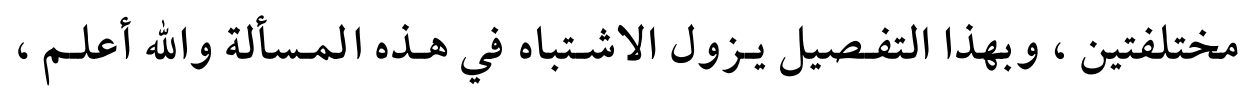

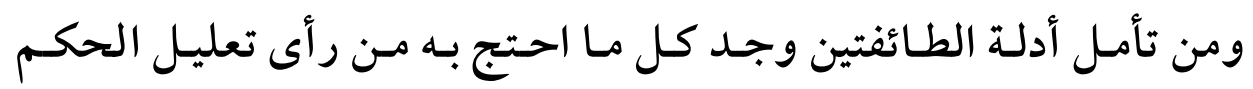
بعلل مختلفـة إنـما يـدل عـلى تعليـل الو احـــــــالنوع بهـا، وكـل مـن نفي تعليل الحكم بعلتين إنما يتم دليله على نفي تعليل الواحـد بـالعين بهـما ،

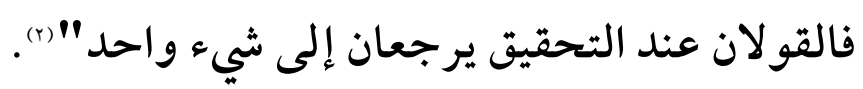

$$
\text { (1) (1) انظر : المسودة ص (Y) (1V) }
$$
(Y) انظر : مفتاح دار السعادة لابن القيم / / ؟ ط ط: دار الكتب العلمية - بيروت. 
(ar $)$ تعلد العلل وأثره عند الأصوليين "دراسة أصولية تطبيقية" الإطلب الثاني

\section{العلل المتعددة كل واحدة هنها علة هستقلة لا جزي علة}

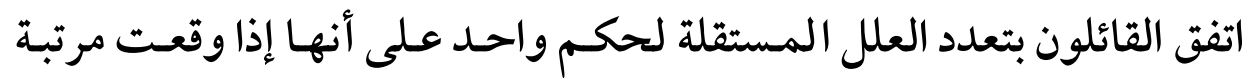
فإنَّ الحكم بالأولى، وإذا وقعت دفعة كمن بال، وتغوط، ومسّ معـاً، اختلفوا في ذلك على ثلاثة مذاهب:

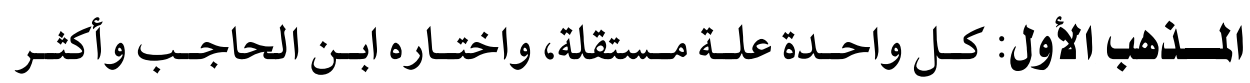
الأصوليين - رحمهم الله تعالى. (1)

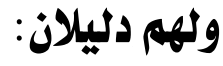

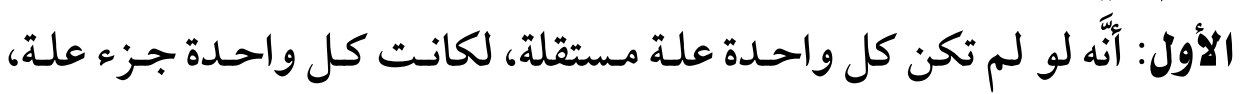
وهو باطل، لثبوت الاستقلال.

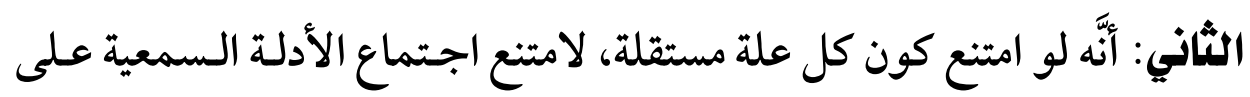

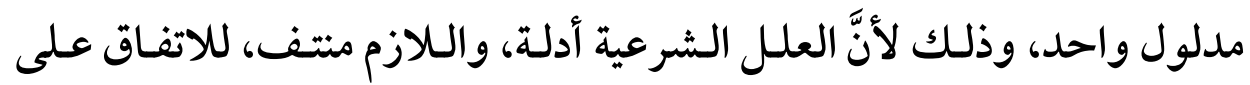

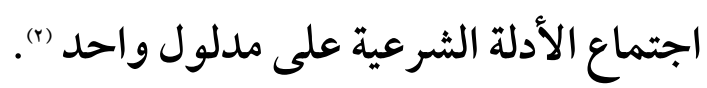

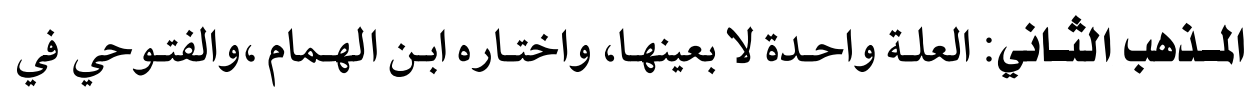

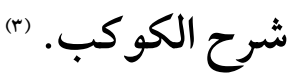

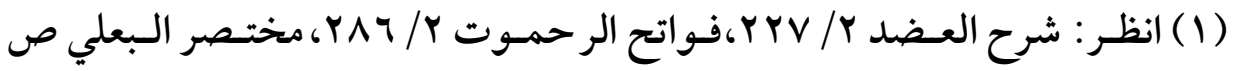
$.1 \leqslant \varepsilon$

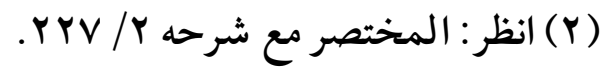

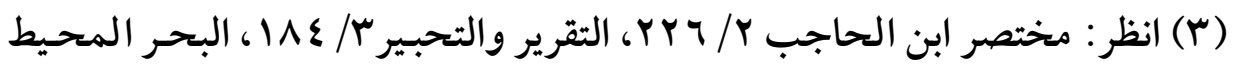

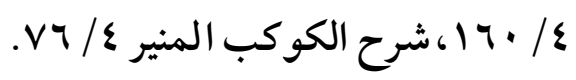


وحجتهم: أنَّهَ لو لا ذلك للزم التحكم في تعيين مـا يثبـت بـه الحكـم دون غيره،

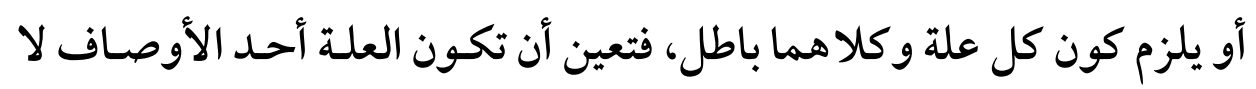
بعينه.

ويجـاب عنـهـ : بأنَّه يثبـت بكل دفعـة، وذلك لا ينـافي الاستقلال، لثبوته عندـ

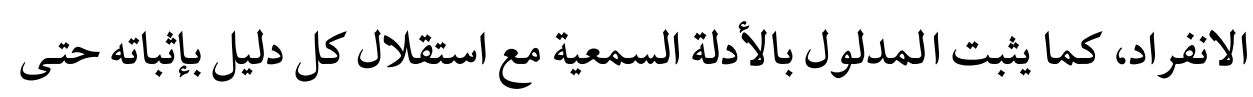
لو انفرد أحد الأدلة لم يمتنع إثباته بالأخرى (1).

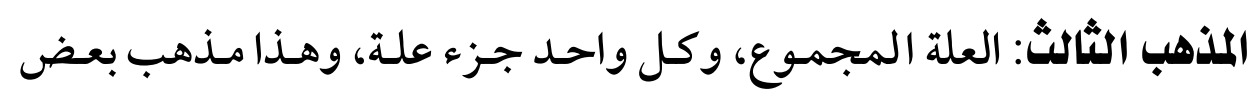
العلماء. ودليلهم على ذلك: أنه لو استقل كل منها بالعلية لزم اجتماع المثلين.

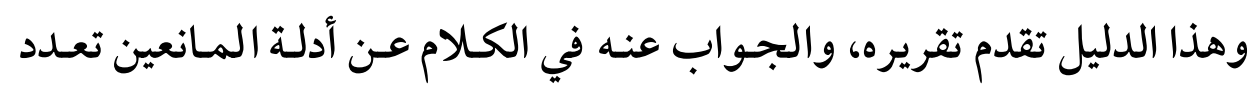

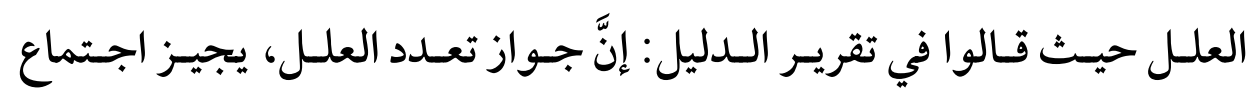
المثلين، واجتماع المثلين يوجب اجتماع النقيضين.

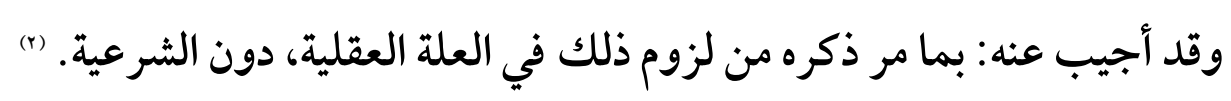

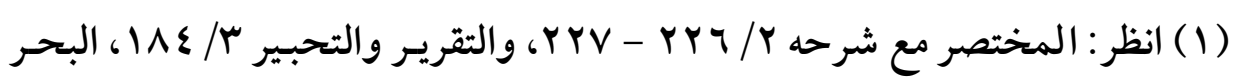
المحيط \&/ • 17.

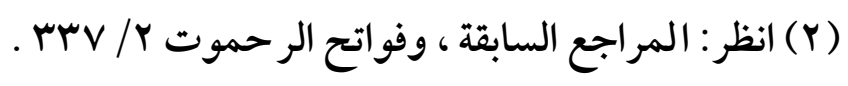




\section{نوع المكم الثابت بالعلل}

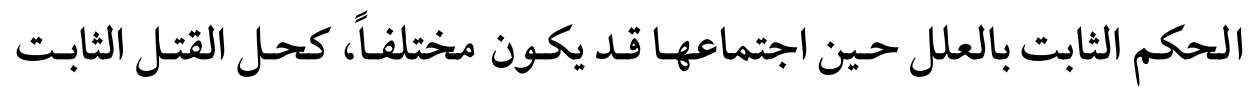

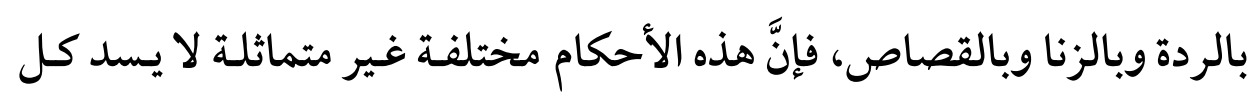

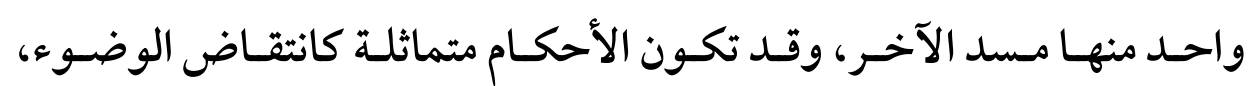

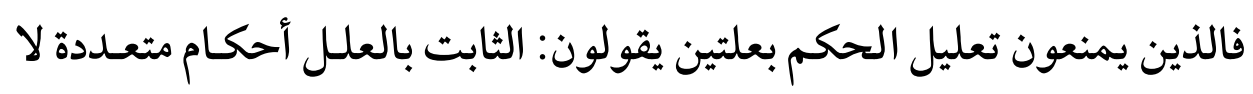

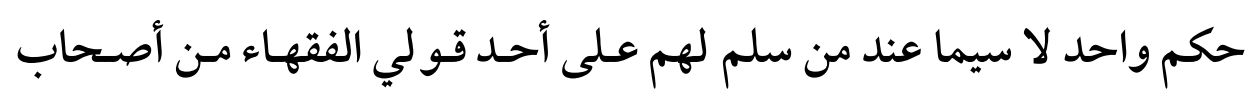

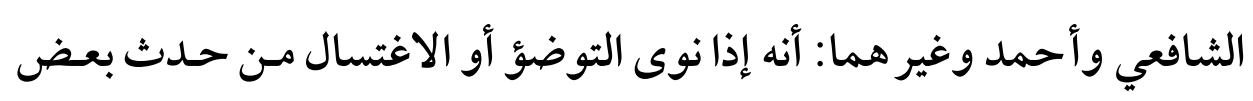

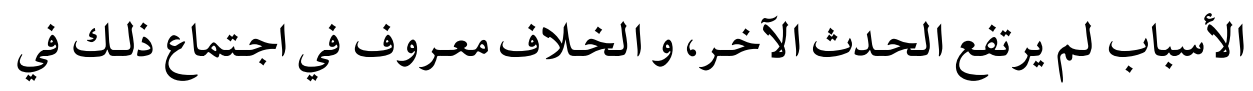

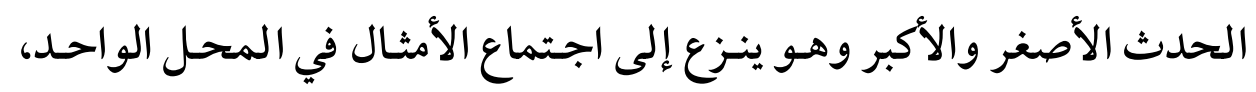

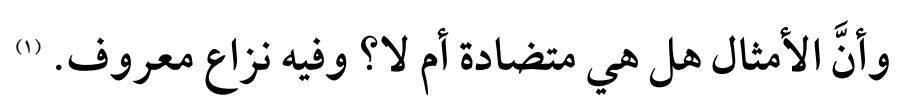
شرط جواز تعدد العلل، يشترط عند القائلين بجواز تعدد العلل ألا يكون هناك تناف ولا تضاد بين العلل.

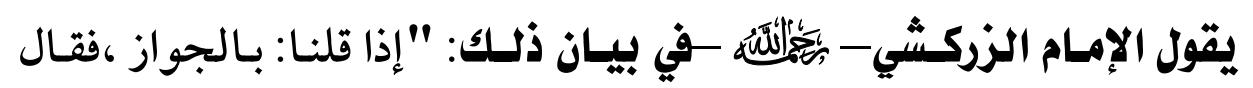
القاضي عبد الوهاب: مـ شرطه أن لا يتنافيا، لـئلا يؤدي إلى تضاد الأحكام

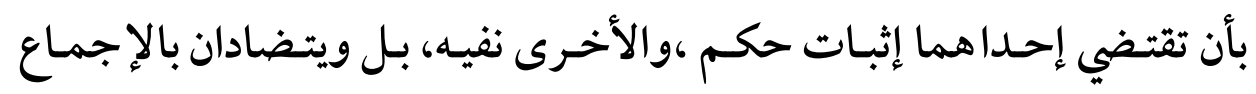

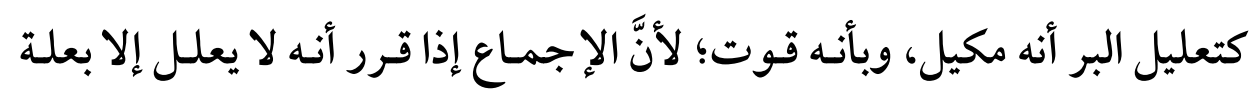
واحدة وجب التنافي . (r) - 2

$$
\begin{aligned}
& \text { (1) انظر : مجموع الفتاوى لابن تيمية • IVI/Y) }
\end{aligned}
$$

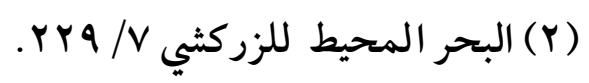




\section{المبحث الثالث \\ ها ترتب على القول بجماز تعدد العلل}

وفيه ست مسائل:

المسألة الأولى: تعليل الحكم بعلتين دلت إحداهما على حكم الأصل، والأخرى له تلدل عليه

إذا كانـت إحــى العلتين دليلاً عـلى حكـم الأصـل دون العلـة الأخـــى فهل

يجوز التعليل بها؟

مثال ذلك: قول الحنبلي في الطلاق قبل النكاح: أنـه لا ينعقــ؛ لأنَّ مـن لا ينفـذ بهذ طلاقه المباشر لا ينعقد له صفة الطلاق، ودليله الصبي. فيقول الحنفي: إنه ينعقـد طلاقه، والعلة في الصبي أنـه غير مكلف، وهـذا الرجل مكلف أضاف الطلاق إلى ملكه.

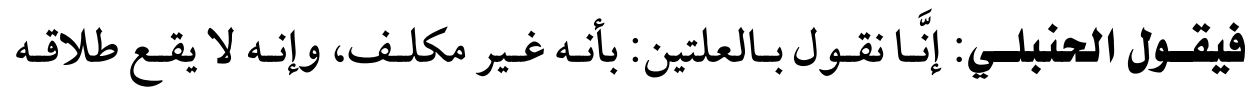
المباشر و هما غير متنافيين. اختلف العلماء في ذلك على مذهبين: المذهب الأول: لبعض العلماء من الحنابلة، أنه يجوز تعليل الأصل بالعلة التي

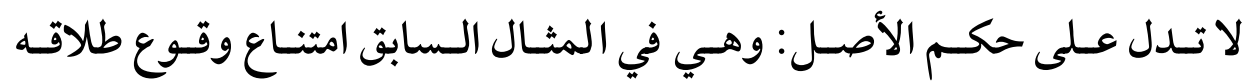
المباشر.

وحجتهم على ذلك: أنَّ العلة التي ثبـت بها حكمى الأصل هي طريق في حكـم

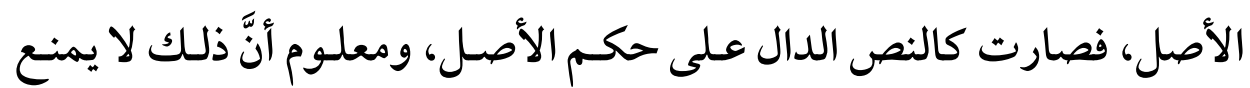

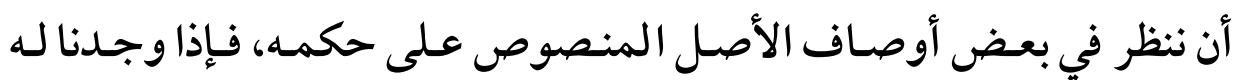

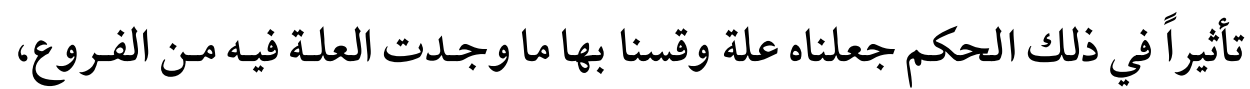


(qYA)

تعدد العلل وأثره عند الأصولييز "دراسة أصولية تطبيقية"

كذلك ما ثبـت حكمه لعلة مـن العلل، لا يمنع أن ننظر بعض أنس أوصـافه، فيإذا

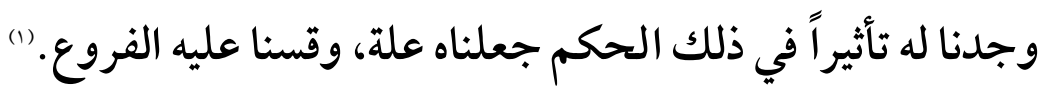
المذهب الثاني: لبعض العلماء من الحنفية أنه لا يجوز تصحيح العلة التي لم يثبت بها حكم الأصل. وحجتهم على ذلك: أنَّ هذه العلة لا يمكن أن تـدل على أن بثبو تها ثبـت حكـم

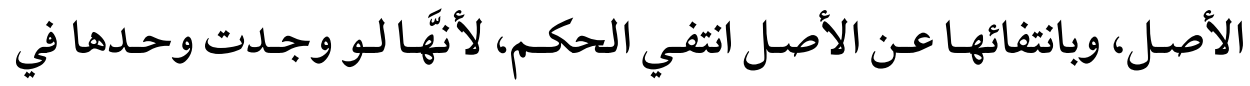

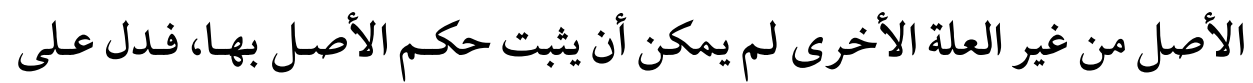
أنها غير صحيحة، وأنها لا تثبت في الأصل. (r) والراجح: المذهب الأول، فيجوز تعليل الأصل بالعلة التي لا تدل على حلى حكـم الأصل.

\section{المسألة الثانية: زوال إحلى العلتين في الحكم المعلل بعلتين}

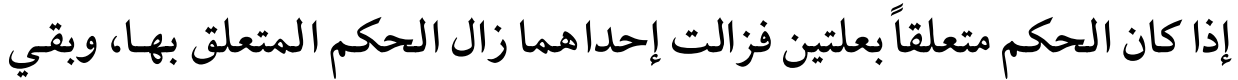

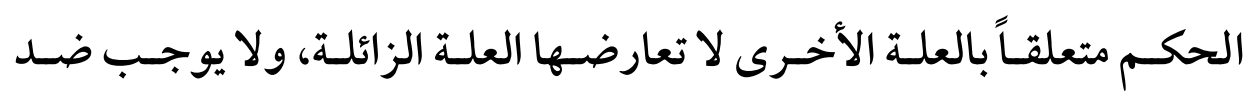
حكمها.

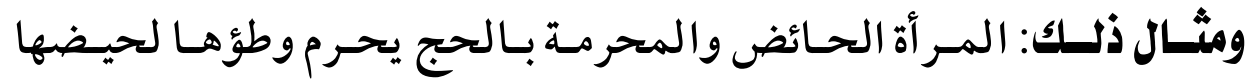
ولإحر امها، فإذا انقطع حيضها بقي تحريم وطئها متعلقاً بالإحرام. (r)

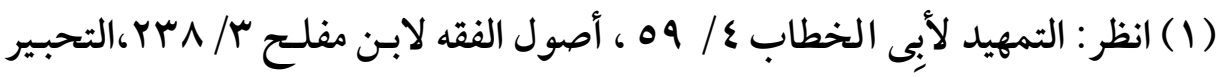

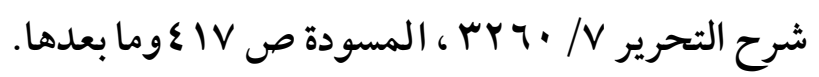

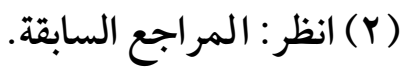

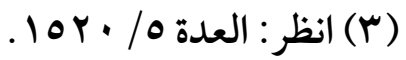




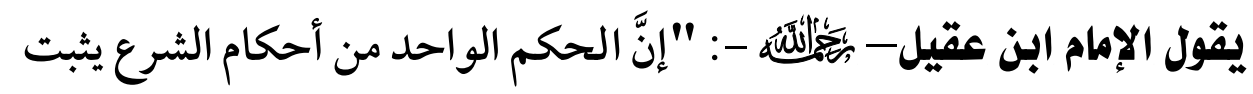
بعلتـين، فإذا زالـت إحــاهما بقيـت الأخـــى، فلـذلك لم يكـن مـن ضرورة

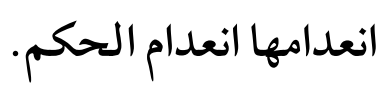

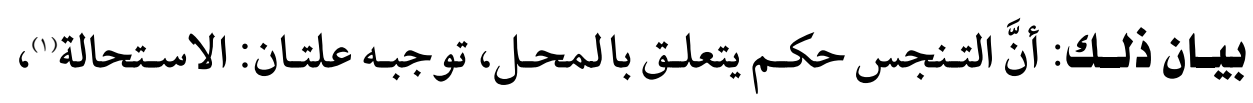

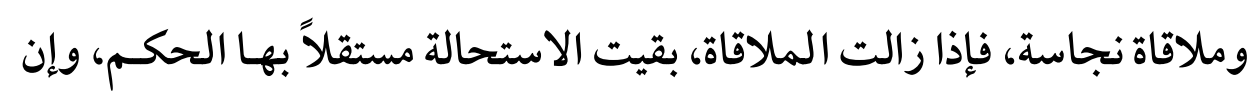
زالت الاستحالة، بقيت الملاقاة، فلم ينتف الحكم بزوالها وانتفائها؛ فلـذلك بلك

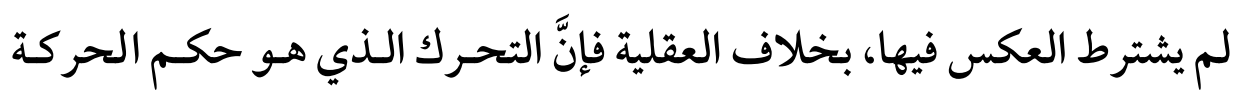

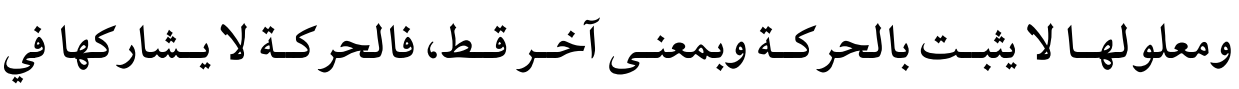

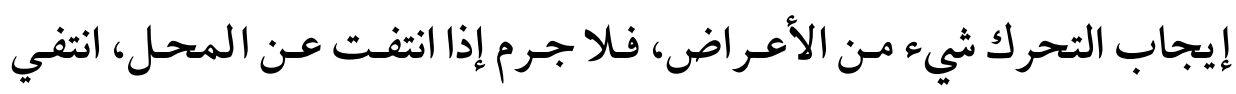
حكمها -وهو تحرك المحل -لا محالة. المسألة الثالثة: تعليل الحكم بعلتين إحلداهما أعم من الأخرى

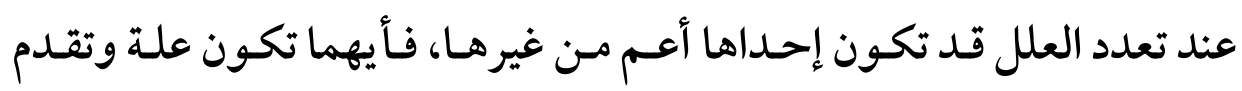
على غيرها؟ إن كانت إحدى العلتين أعم مـ الأخرى، فليس يمتنع أن تكونـاصحيحتين

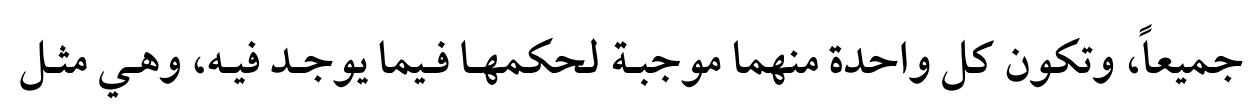

(1) معنى الاستحالة لغة: جاء في معنى حال: كل شيء تغير عن الاستواء إلى العوج،

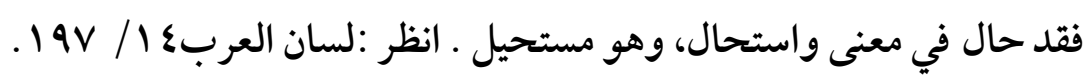

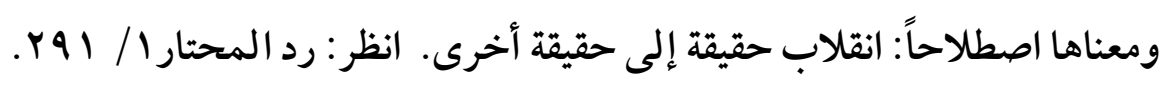

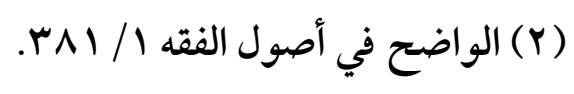


$(94 \cdot)$

تعدد العلل وأثره عند الأصولييي "دراسة أصولية تطبيقية"

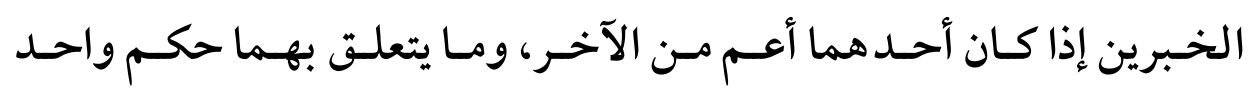
فيستعملان جميعاً. (1)

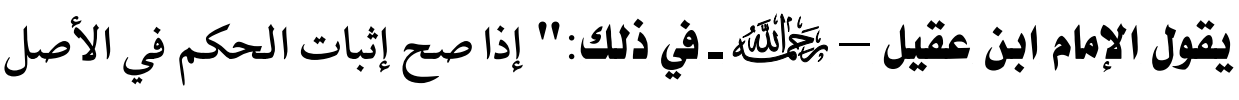
بعلتين، وتعليله بعلتين، وكان أحد الوصفين أعم من الآخر، ودل الدليل على صحة كل واحدة، كان المعلل بالخيار بين أن يستدل بالعامـة وبين أن يستدل بالخاصة، كالخبرين؛ أحـد هما يـدل على حكـم بعمومـه، والأخـر يـدل عليه بخصوصه، كان مخيراً في الاستدلال بأيهما شاء. وقال قوم: الخاصة أولى؛ لأنها تصرح بـالحكم. ولم يسلموا أنَّ الخبر العـام يساوي الخـاص، بـل الخـاص في الحكـم المقـدم. (r). والر اجح: هـو القـول

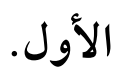

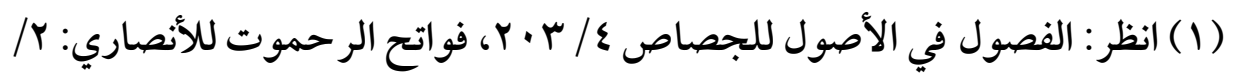

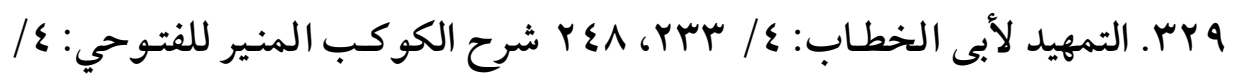

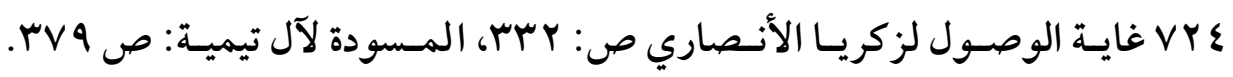

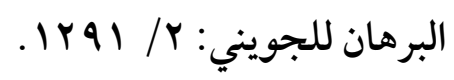

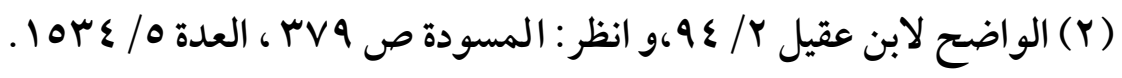


(qr)

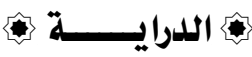

المسألة الرابعة: تعليل الحكم بعلتين إحداهما فروعها أكثر من الأخرى

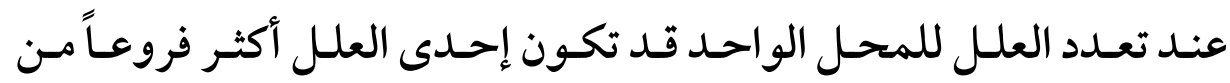

الأخرى فكيف يكون التعليل بهما؟

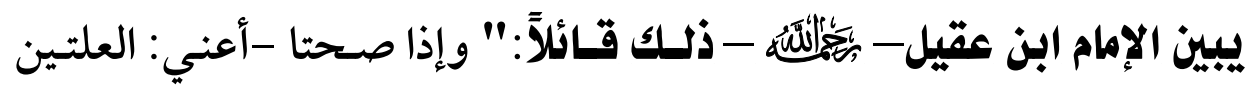
المثبتين للحكم فلا فرق بين أن يكون فروع إحـدا هما أكثر مـن الأخرى أم إمئن (1). تتساوى وقال قوم من أهل الجـلدل: "مـن شرط صحتهما أن تتساويا في الفروع؛ لأنَّ الكثيرة الفروع هي التي يثبت بها الحكـم، فـلا يحتـاج في إثباته إلى مـا قلـت

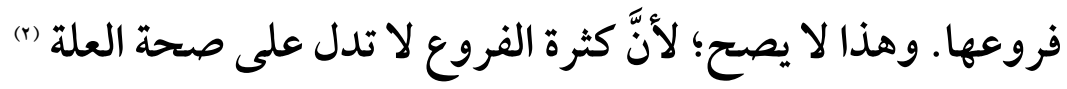

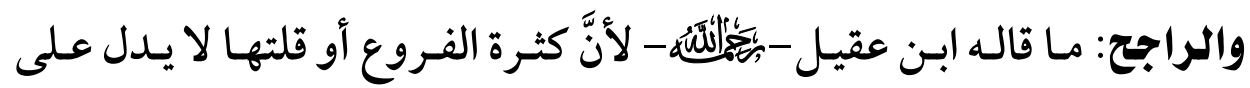
صحة العلة أو قو تها.

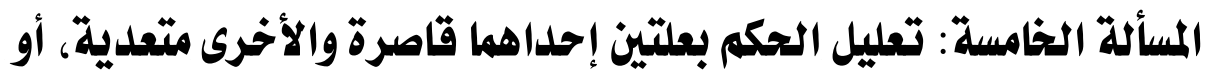
إحلداهما أكثر تعلديا من الأخرى إحلى

في الحالة الأولى: هل يعلل بالعلة القاصرة ويمنع التعدي بالعلة المتعدية؟

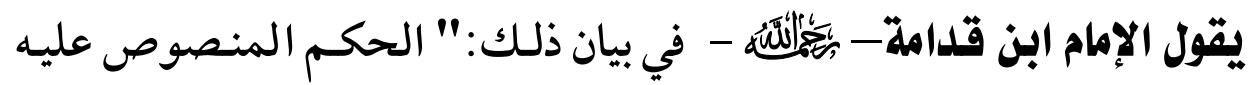
إذا اشتمل على حكمتين - أي علتين - قاصرة ومتعدية هل يجوز تعديته؟

(1) وهـو اختيـار القـاضي أبي يعسلى، وأبي الخطساب، وعليه أكثر الشافعية. انظـر:

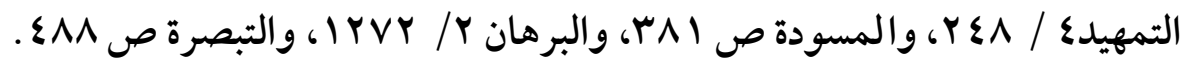

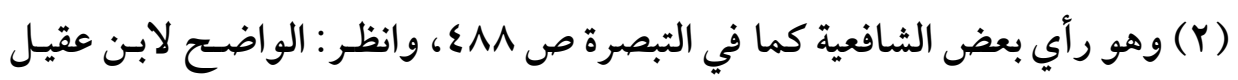
$.9 \varepsilon / Y$ 
(arr)

تعلد العلل وأثره عند الأصوليين "دراسة أصولية تطبيقية"

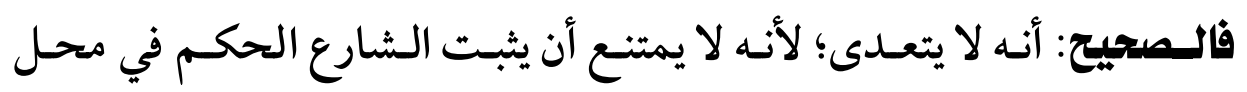

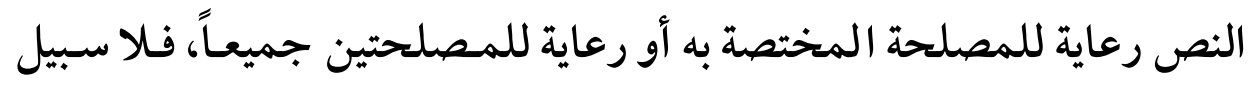
إلى إلغاء هذين الاحتمالين بالتحكم ومع بقائهما تمتنع التعدية. (1)

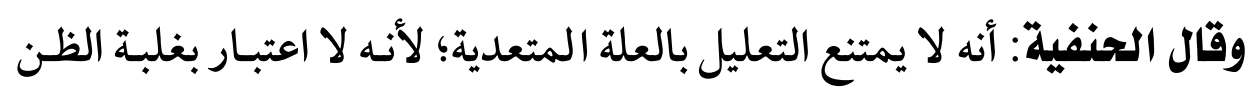

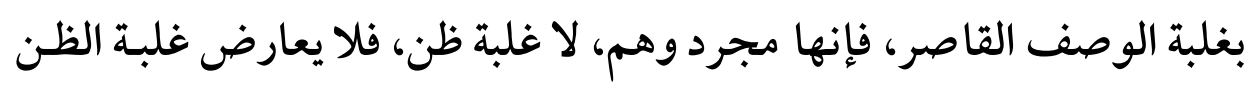
بغلبة الوصف المتعدي المؤثر (r).

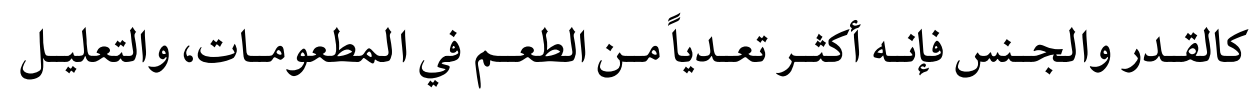

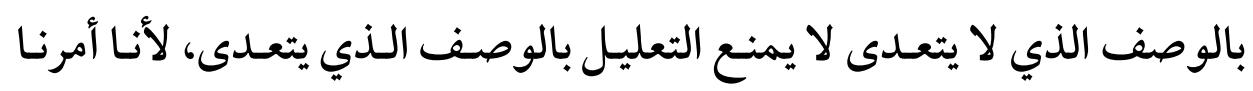
بالاعتبار، وبهذا الوصف أمكن الاعتبار فوجب التعليل به فيبطل دعوى فائدة اختصاص النص بـه، وهـذا في الحاصـل منـع لمـا ادعـاه الخصصم مـن إفـادة

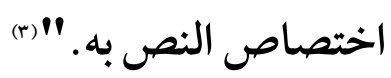

وفي الحالة الثانية: أن تكون إحداهما أكثر تعدياً من الأخرى فيجوز التعليل

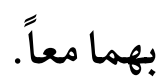

(1) روضة الناظر لابن قدامة ص 1N11.

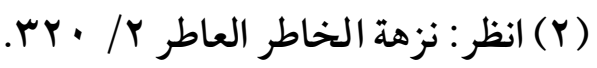

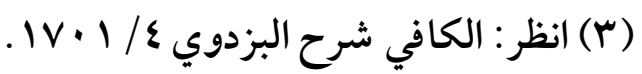


(qrr)

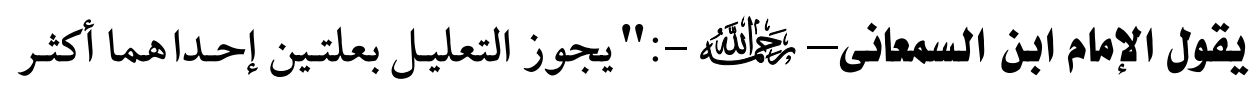

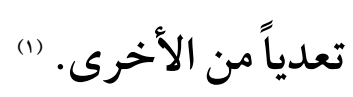

\section{المسألة السادسة: الترجيح بكثرة العلل}

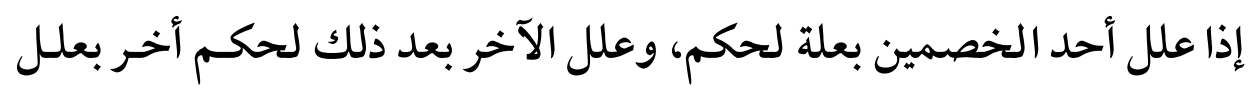

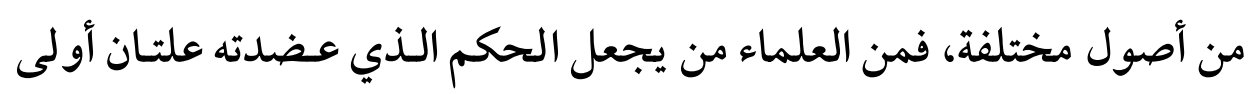
من الآخر الذذي لم يوجبه إلا علـة واحـدة، ويجعله بمنزلة علـة شهـدت لها أصول كثيرة، والأخرى شهد لها أصل واحد، ومنهم من يجعل العلة الواحـدة

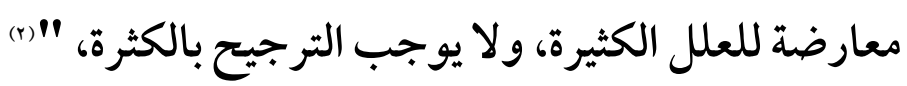

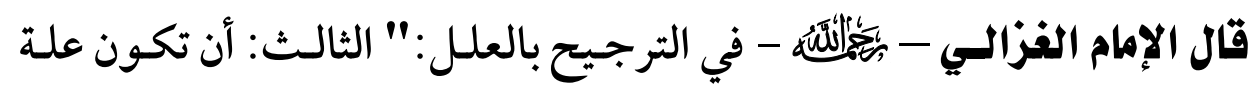

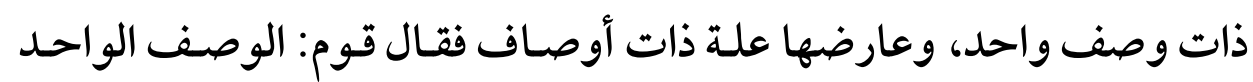

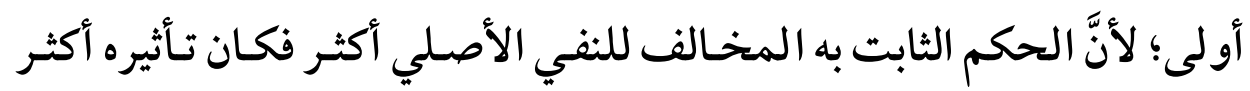
فروعاً فهي أكثر تأثيراً. وقـال قـوم: ذات أوصـاف أولى؛ لأنَّ الـشريعة حنيفيـة، فالبـاقي على النفي الأصلي أكثر، ولا يبعد أن يغلب على ظن المجتهد شيء من ذلك. (r)

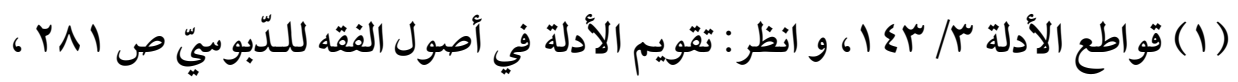

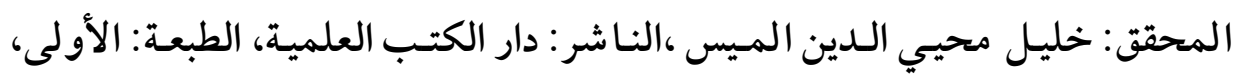

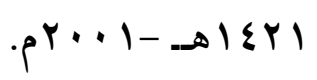

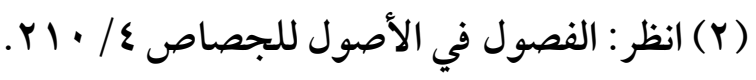

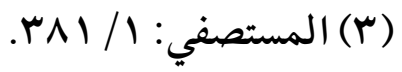


(qฯ ६)

تعلد العلل وأثره عند الأصوليين "دراسة أصولية تطبيقية"

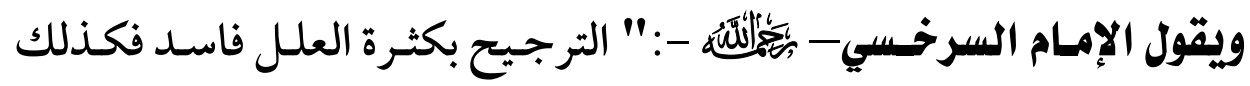
الترجيح بكثرة الأشباه "(1) - الت فالرجحان لا يثبت بكثرة العلل عند الحنفية قياساً على كثرة الشهود.

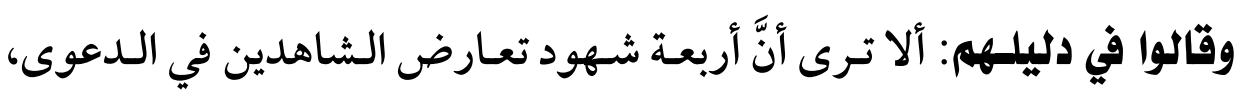
ولا يتر جح الأكثر على الأقل "(r).

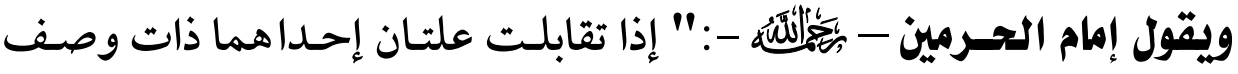
واحد، والأخرى ذات وصفين فصاعدا ، فذهب بعض الجـدليين إلى تقديم التي هي ذات وصف واحد وعللوا بأمرين: أحدهما: أنَّ ذات الوصف الواحد تكثر فروعهاو فوائدها.

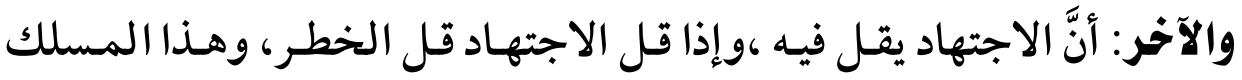
باطل عند المحققين. (r) ()

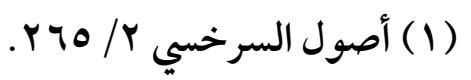

(Y) انظر : الكافي شرح البزدوي للحسين بن علي بـن حجاج بـن علي، حسام الدين

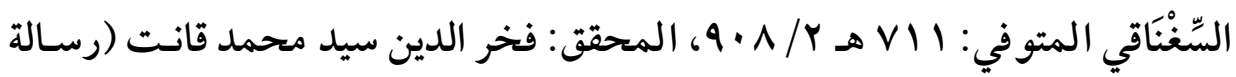

$$
\begin{aligned}
& \text { دكتوراه) الناشر : مكتبة الرشد للنشر والتوزيع. }
\end{aligned}
$$

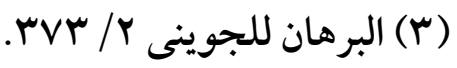




\section{المبحث الرابع}

أثر تعدد العلل عند الأصوليين

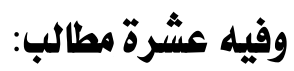

كـان للخـلاف في تعـدد العلل عنــ الأصـوليين أثر كبير في مسائل أصسولية كثيرة في باب القياس بنى الخلاف فيها على الخلاف في حكم تعدد العلل.

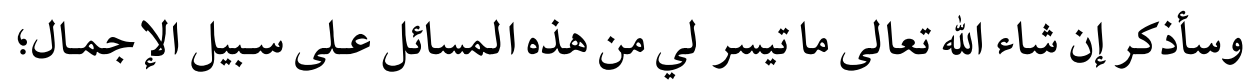

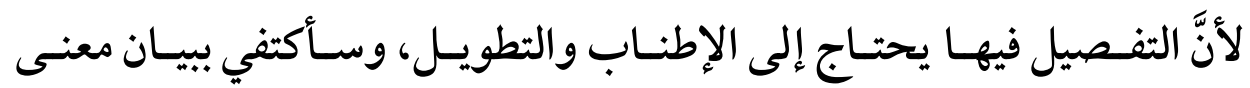

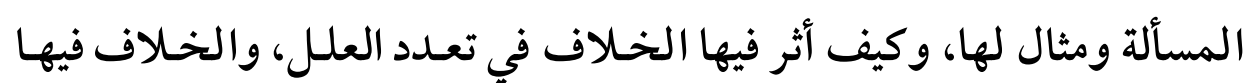

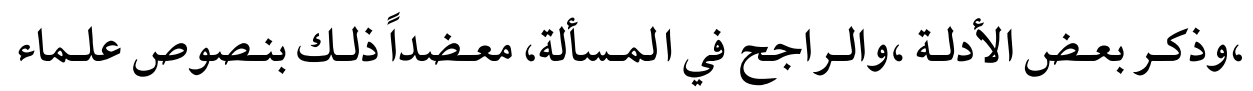

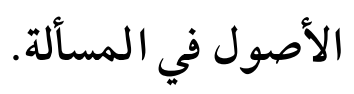

\section{الاملب الأول}

\section{إحداث علة بعد علة}

إذا ثبت حكم في عصر ما بعلة ما، فهل يجوز لمـن يـأتي بعـدهم إحـداث علة

$$
\text { أخرى لهذا الحكم غير علته الأولى؟ }
$$

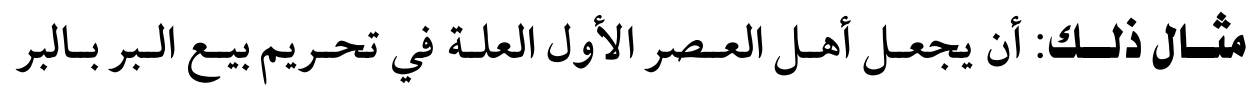

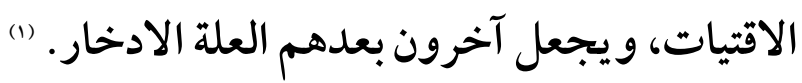

اختلف الأصوليون في ذلك على مذهبين بنـاء على الخـلاف في جـواز تعـدد

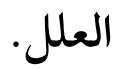


(9ry) تعلد العلل وأثره عند الأصولييز "دراسة أصولية تطبيقية"

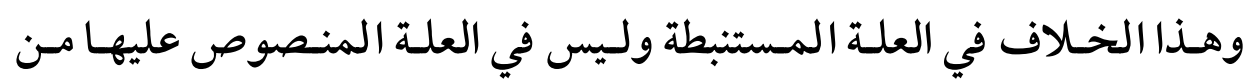

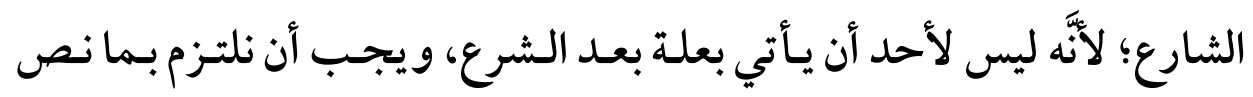

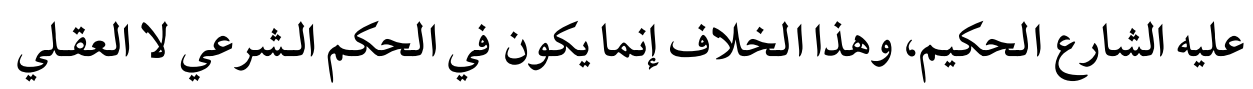

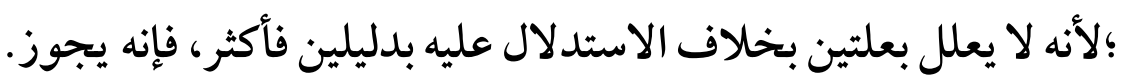

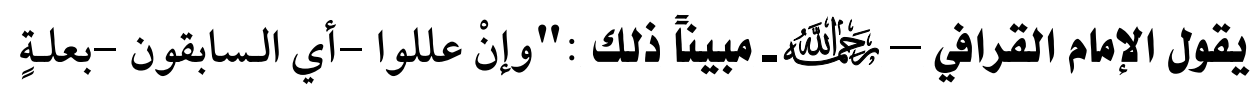

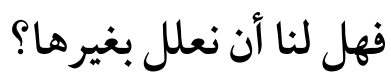

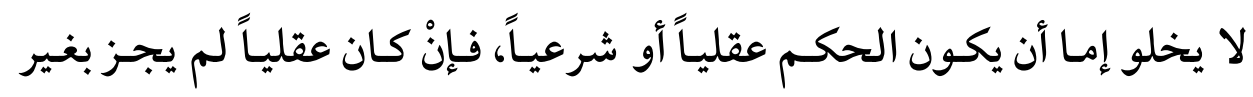
علتهم على أصولنا في أنَّ الحكم العقلي لا يعلل بعلتين، بخحلاف الاستدلال عليه بعلتين، ومن جوزه جوزه هاهنا.

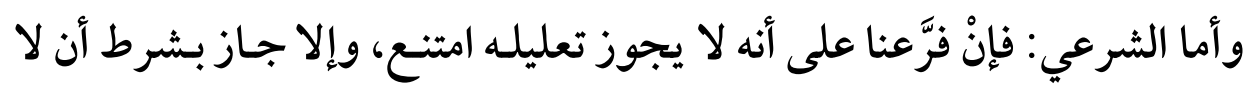

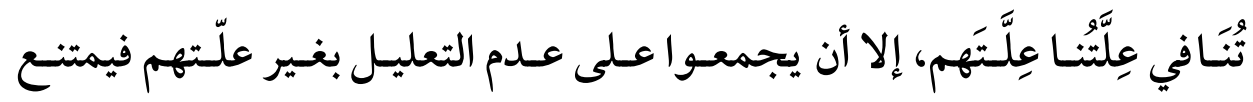
مطلقاً. المذهب الأول: يجوز إحداث علة بعد علة، وهذا مـذهب جمهور الأصسولين، بناء على جواز تعليل الحكـم الواحـد بعلتين، ولأنـه قـد يظهر لعلـماء العصر الثاني ما لم يظهر لعلماء العصر الأول .

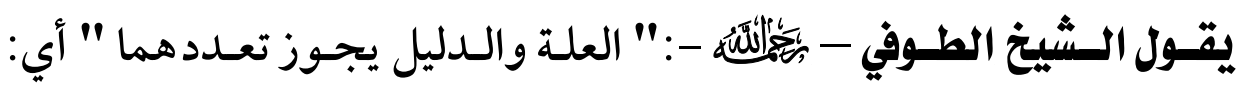

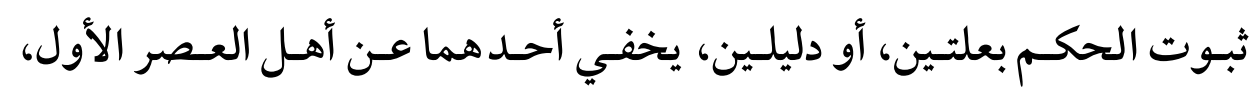

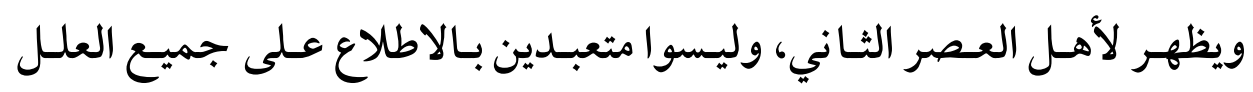

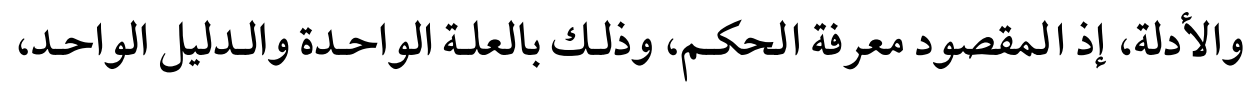

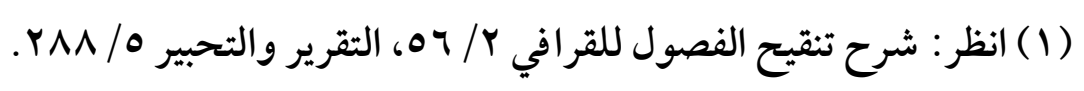


فالعلل والأدلة وسـائل لا مقاصـد، بخـلاف الحكـم، فإنه لا يجـوز تعـدده في

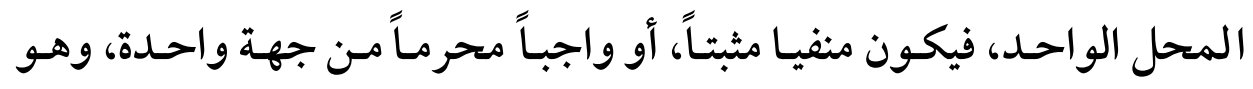
متعبـــــه، مقـصود لذاتـه، فإحداثـه بعـد الاتفـاق عـلى غـيره خـلاف لـسبيل المؤمنين المقصود، ونسبة لهـم إلى تضييع الحقى وإهماله، بخـلاف العلة، والدليل". (1) المذهب الثاني: لا يجوز إحـداث علة بعـد علدة، بنـاء على منع تعليل الحكـم بعلتين؛ لأنَّ علـتهم مقطـوع بـصحتها، ففيـه دليـل عـلى فـساد غيرهـا. وهـــا مذهب بعض الأصوليين (r).

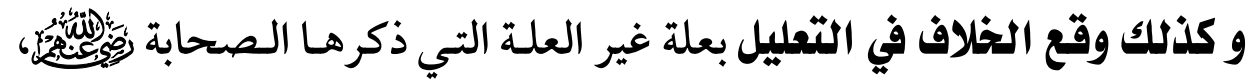
على قولين بناء على أنه هل يجوز أن يعلل الحكم بأكثر من علة واحدة؟

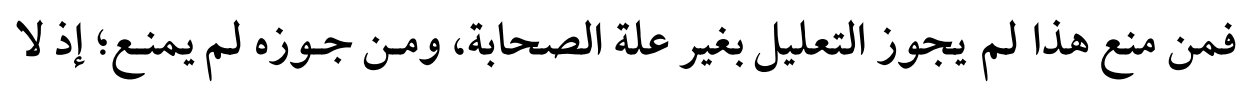

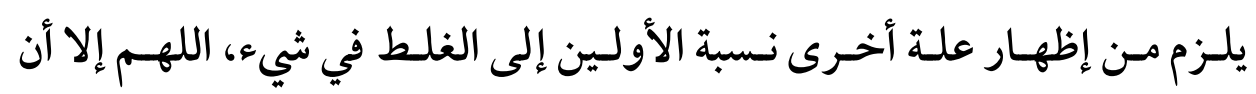

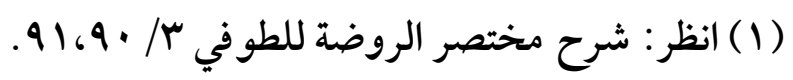

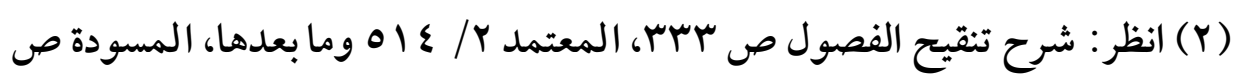

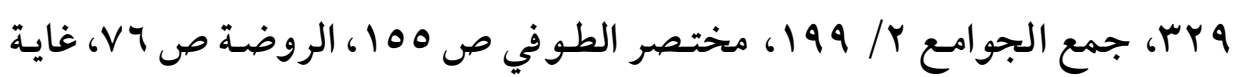

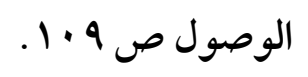


(qrA)

تعلد العلل وأثره عند الأصولييز "دراسة أصولية تطبيقية"

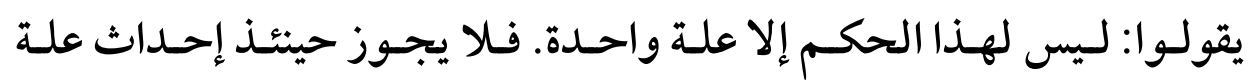
أخرى؛ لأنَّ الأمة اجتمعت على نفيها.

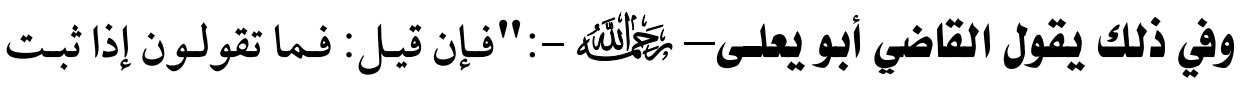
الحكم لعلة، فهل يجوز للصحابة تعليله بعلة أخرى؟ قيل: يجوز ذلك؛ لأنه

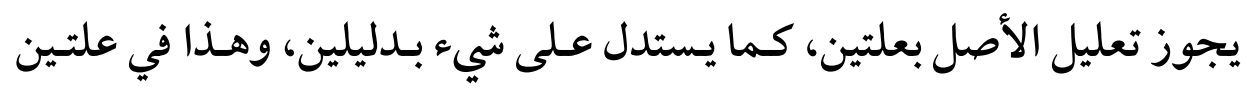

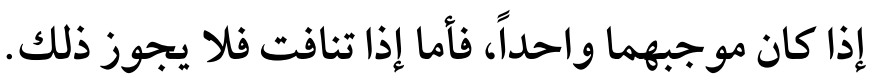

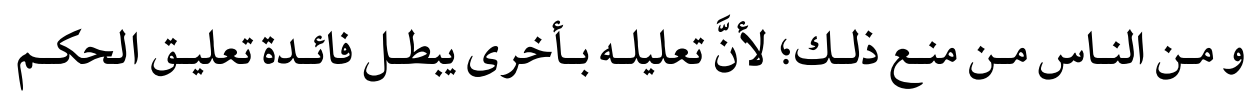
بالأولى، فلا يجوز، كما لا يجـوز ذلك في العقليات، وأنه لا يكسون حكـم

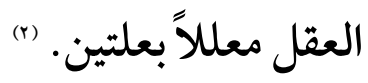

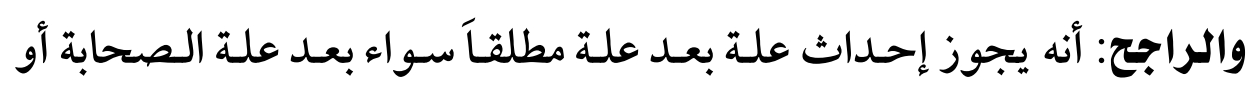

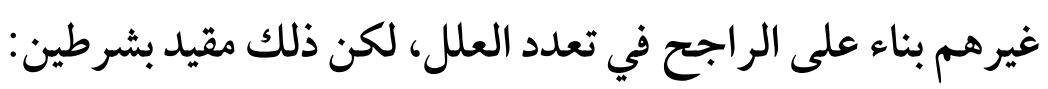

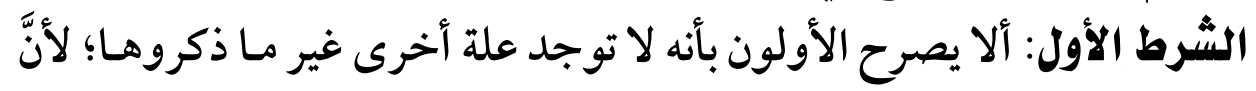
ذلك إجماع على النفي لغير علتهم.

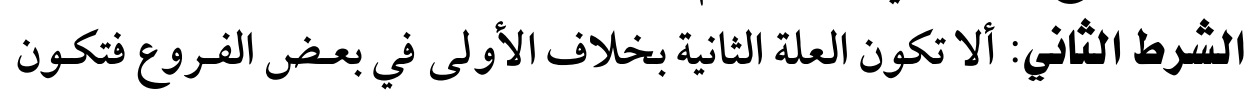
الثانية حينئذ فاسدة. (r)

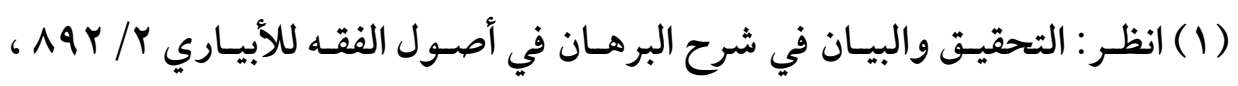

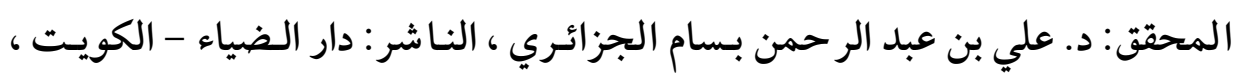

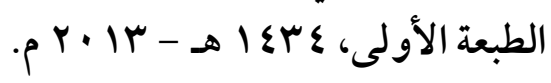

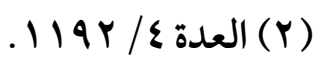

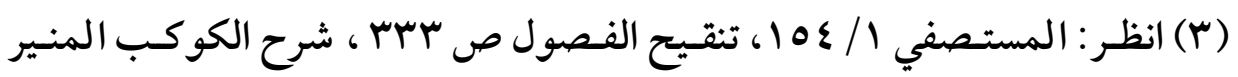

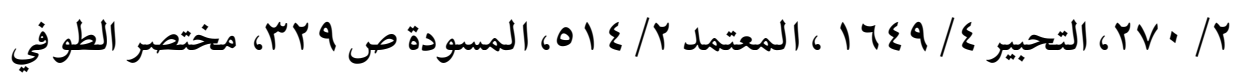

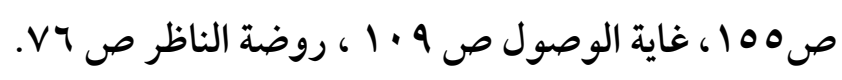


وليس في إحداث علة غير الأولى تضييع وتغيير للحكم الشرعي؛ لاحتمال

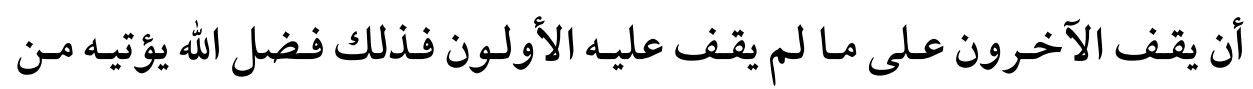
يشاء.

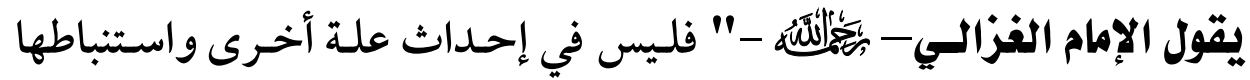
نسبة إلى تضييع الحق. (1)

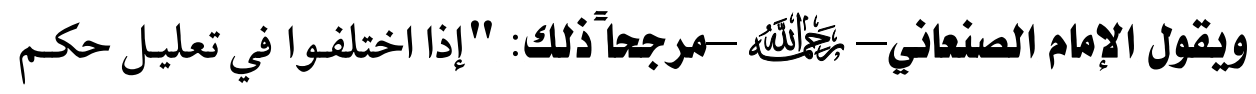
بعلة فهل يجوز لمن بعدهم إحداث علة أخرى لذلك الحكم؟ المختـار: جواز ذلك أيضاً؛ إذ لا مخالفة لمن سبق تقضي ببطلان تعليلهم، واقتصار الأولين على علة لا يقضي بـالمنع مـن إحـداث غيرهـا، ومـن قـال لا يجـوز علل ذلك

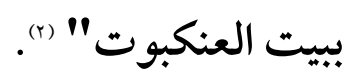

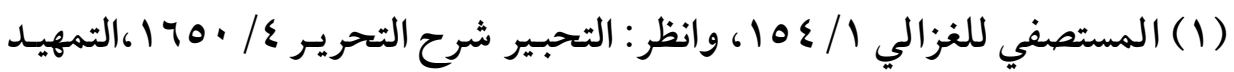

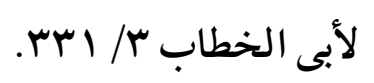
(Y) أي بأدلة ضعيفة واهية كبيت العنكبوت كما سبق بيان ضعف هذه الأدلة في الكلام في حكم تعدد العلل ،وينظر كلام الصنعاني في كتابه: إجابة السائل شرح بغية الآمل

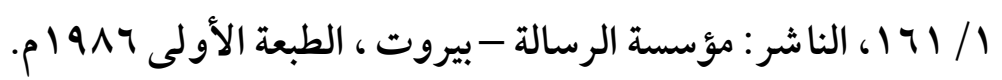




\section{الإطلب الثاني}

\section{القياس على ها ثبت بالقياس}

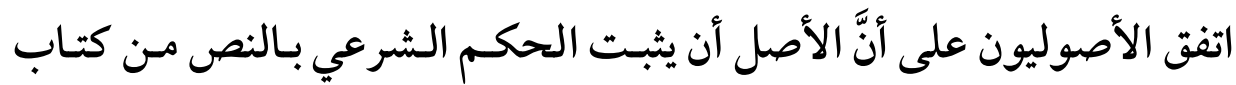

أو سنة، واختلفوا إذا ثبت حكم الأصل بالقياس، فهل يجوز القياس عليه؟

اختلف الأصوليون في هذه المسألة على قولين، وقد ذكر الزركشي في البحر

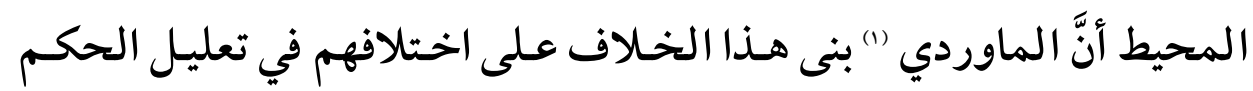

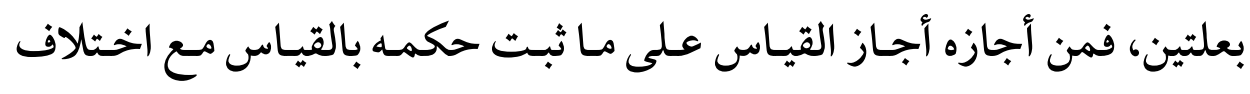
العلة. (r)

ومثاله: قياس الأرز على البر في تحريم التفاضل بعلة الكيل، ثم يقيس المـوز

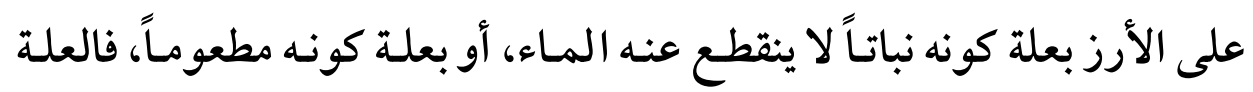
الأولى غير موجودة في البر، والثانية موجودة.

(1) هو القاضي أبو الحسن علي بن محمد الماوردي البصري الشافعي ، ولد بالبصرة

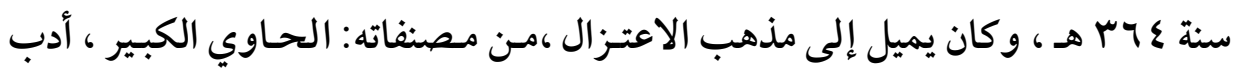

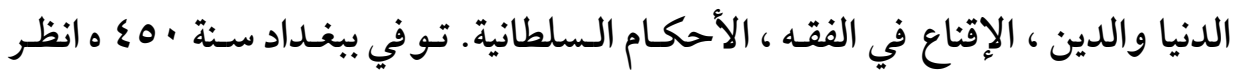

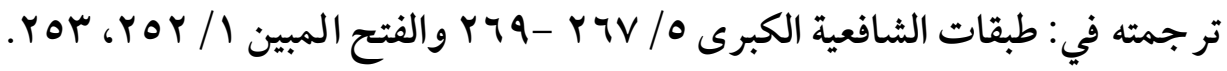

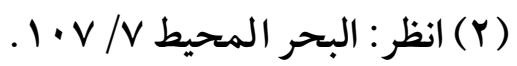


(9६1)

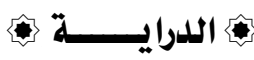

القـول الأول: أنَّهـ لا يجـوز القيـاس عـلى أصـل ثبــت بالقيـاس. وهــا قـول

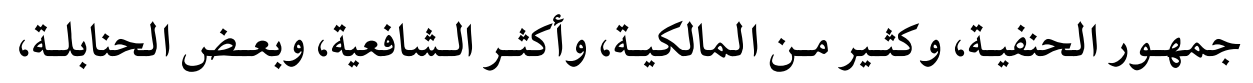

$$
\text { وغيرهم. (1) }
$$

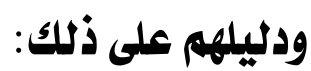

أولاً: أنَّه إذاعرف على دليل الأصل في القياس الأول فينبغي أن يقيس عليه مباشرة بلا واسطة، وإن لم يعرف دليل الأصل في القياس الأول فلا يجوز القياس.

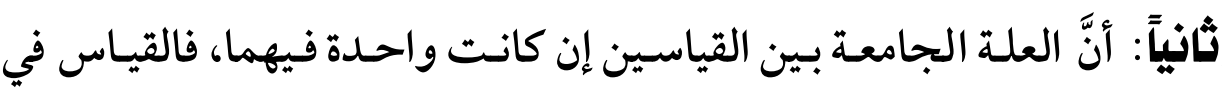

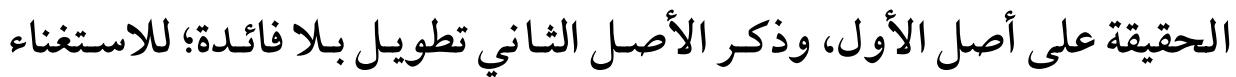
عنه بقياس الفرع الثاني على الأصل الأول.

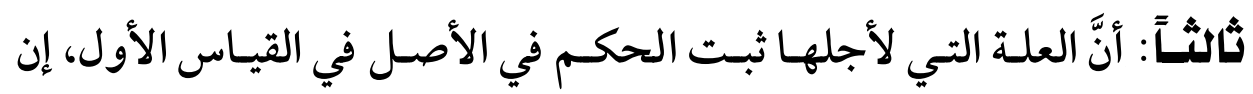

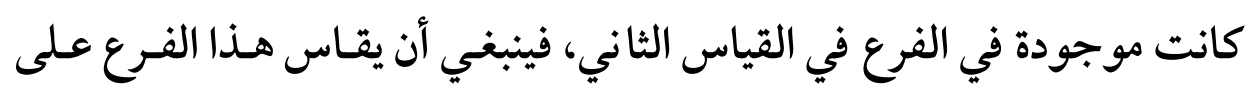

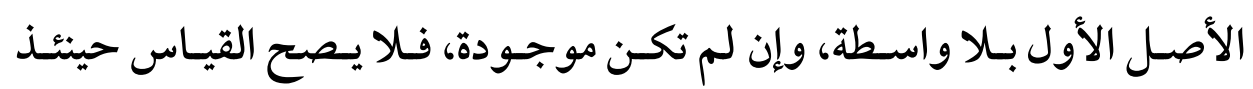

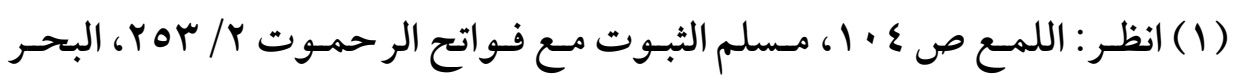

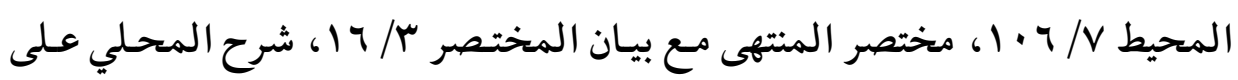

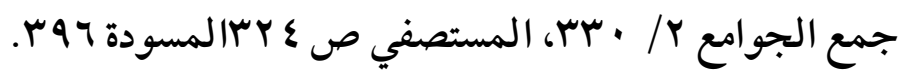


(q६r)

تعلد العلل وأثره عند الأصوليين "دراسة أصولية تطبيقية"

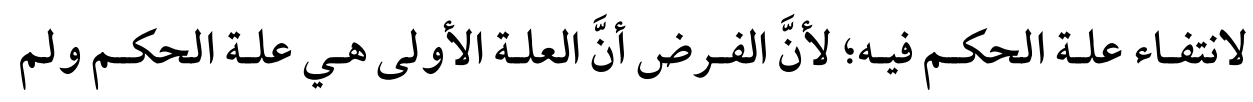
توجد في الفرع الثاني. (1)

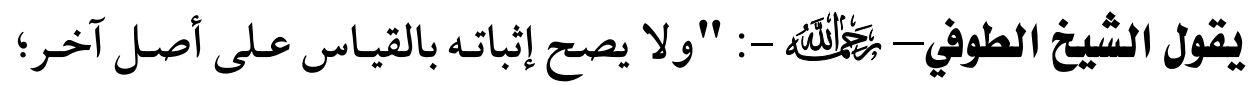

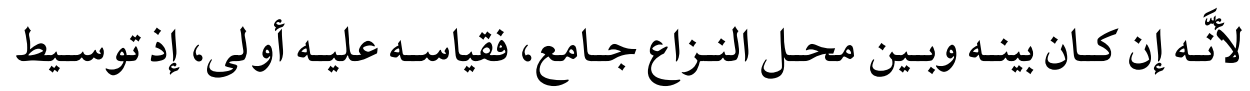

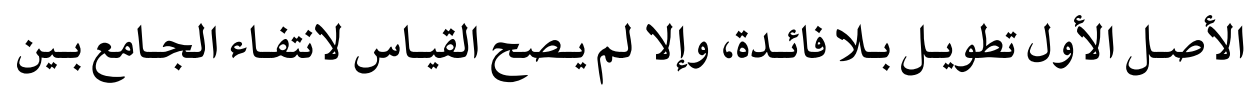
محل النزاع وأصل أصله (r).

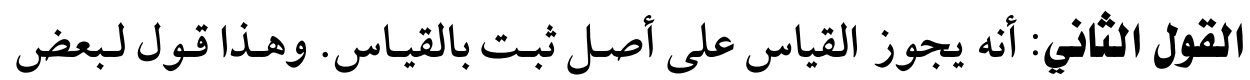

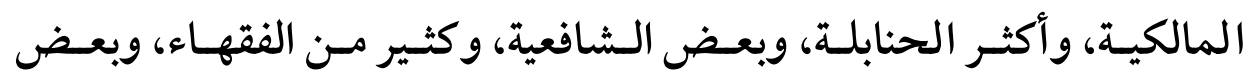
المعتزلة.

ودليلهم على ذلــك: أنَّ الفـرع لمـا ثبـت الحكـم فيـه بالقياس صـار أصلاًا في نفسه، فجاز أن يستبط منه معنى ويقاس عليه، كالأصل الثابت بالنص (r) ".

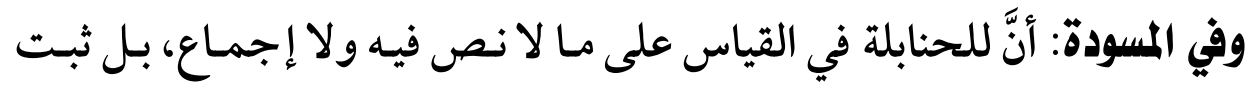

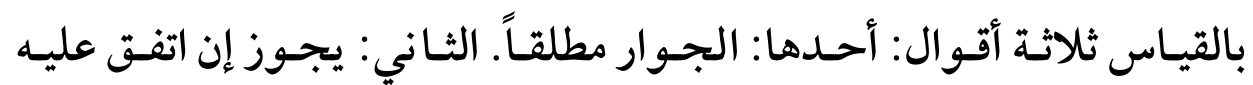

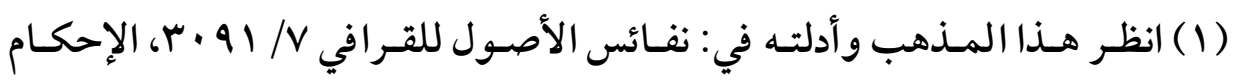

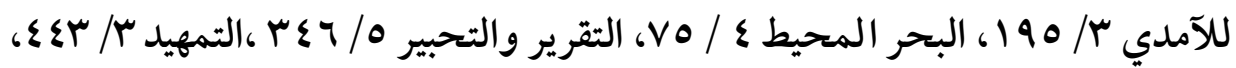

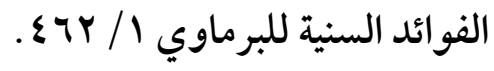

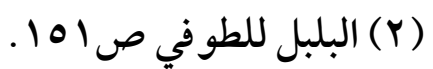

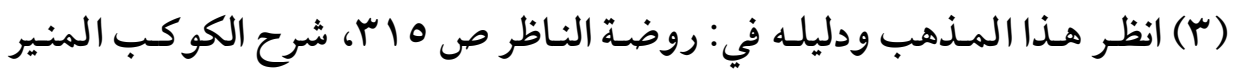

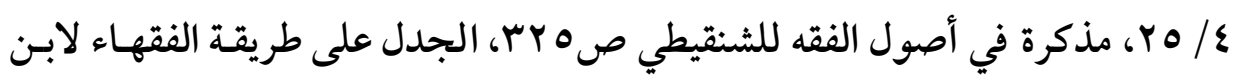

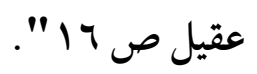


الخصمان. الثالث: يجوز مطلقاً، وإن كانـت العلـة في الأصل المحض غير العلة في الفرع المحض بل في الفرع المتوسط علتان. (1)

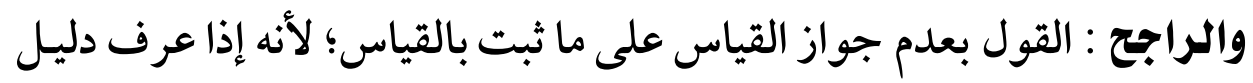

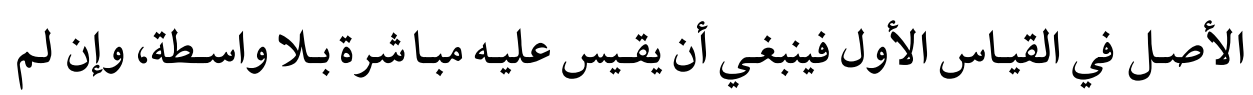
يعرف دليل الأصل في القياس الأول فلا يجوز القياس.

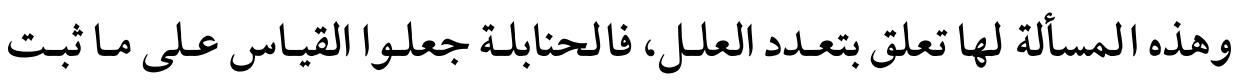

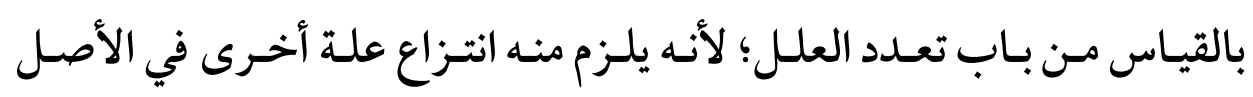

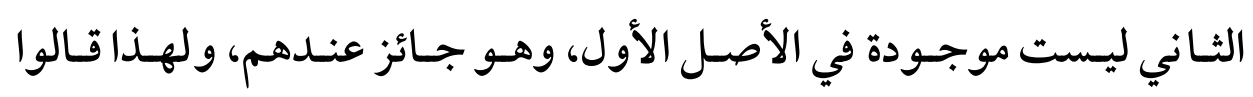
بجواز القياس على ما ثبت بالقياس. وبعض الأصوليين ذهـب إلى عـدم جـواز القياس على بـ مـا ثبــت بالقيـاس بنـاء على المنع من تعدد العلل.

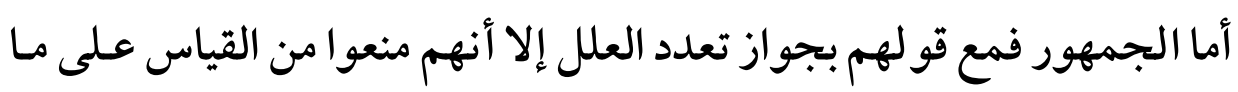

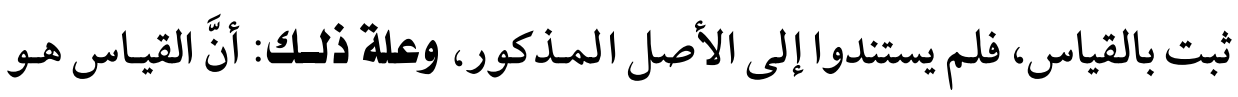

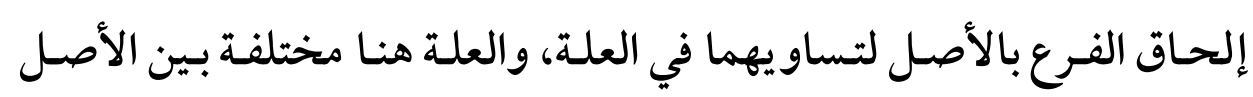
والفرع، فلا مساواة بينهما، فالحكم ثبت في الأصل الذي هو فرع لأصل آخر لعلة أخرى غير العلة التي يقاس بها عليه. (r)

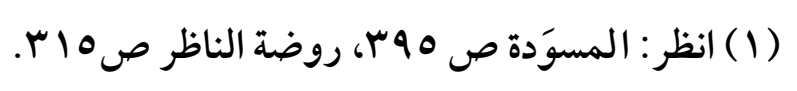

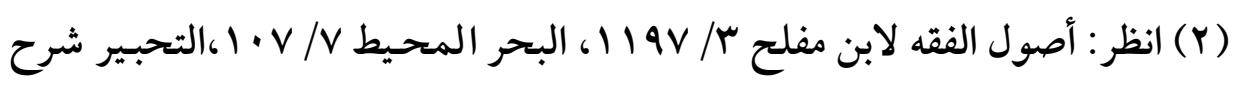

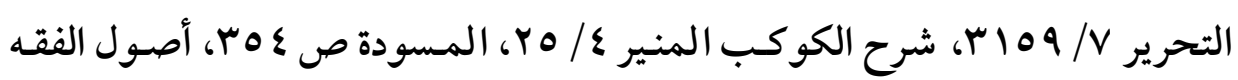
الذي لا يسع الفقيه جهله ص • 11. 
(9६६)

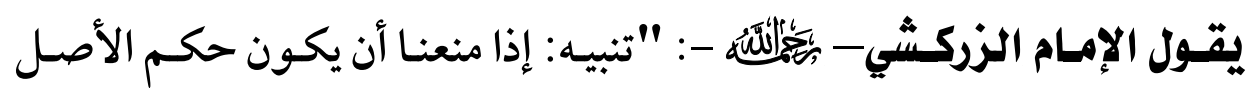
قياساً، يستثنى منه صورتان:

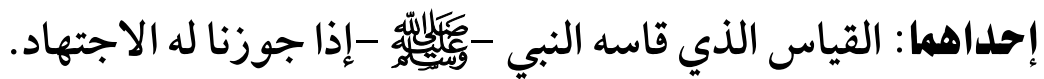

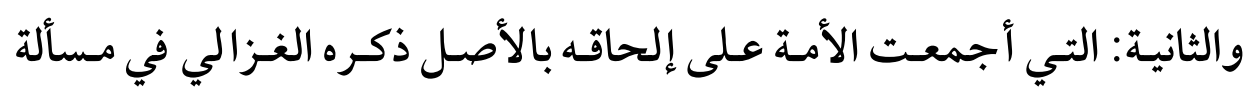
الاجتهاد.

\section{الإطلب الثالث}

\section{وجود المكم همع عدم العلة (عدم التأثير)}

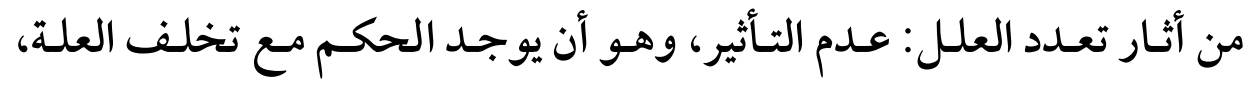
ويسمى عند الأصوليين عدم التأثير، أو عـدم العكس، وهـو وهـ مـن القـوادح التي

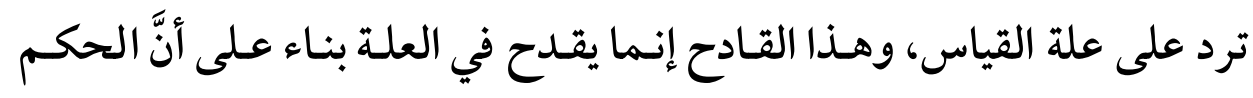

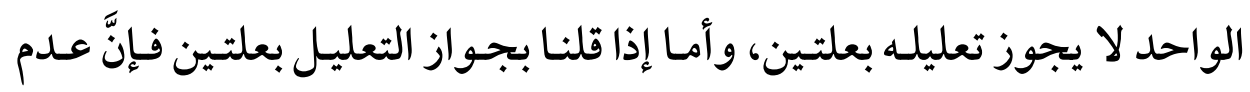

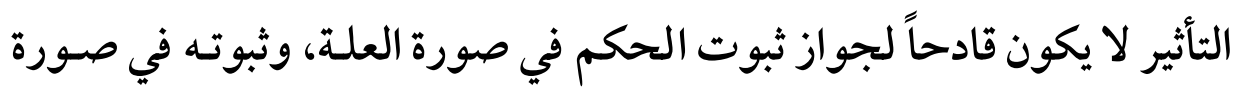
أخرى لعلة أخرى.

والتأثير: عبارة عن ظهور مناسبة العلة في نفسها، أو في اعتبار الشرع في غير

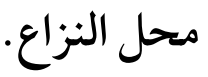
ومنه: ظهر أنه لا يعترض على المنصوصة، أو المجمع عليها إذ الحكم يزول بزوالها.

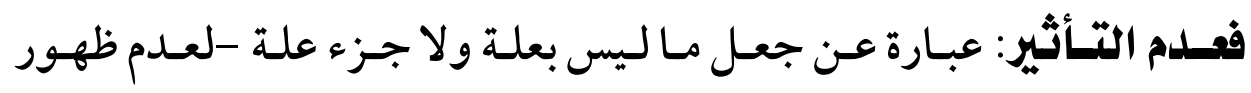
علامتها -كذلك. 
$(9<0)$

وعند هذا ظهر الفرق بينه وبين العكس، وإن زعم بعضهم أنه لا فرق بيـنهما؛

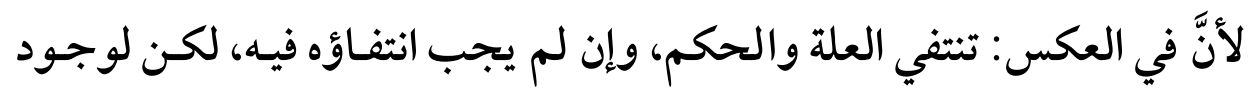

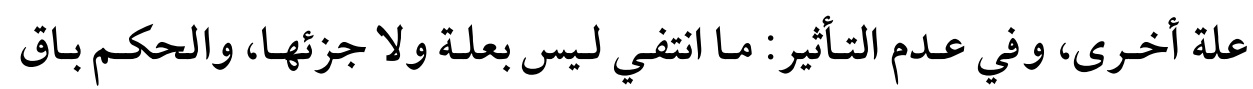
لبقاء علته.

فعلدم التأثير معناه: وجود الحكم بدون الوصف الذي ثبتت عليته فيه. فالعلة إذا عدمت عدم الحكم المتعلق بها بعينه، كمن يجوز وجود مثل ذلك الحكم بعلة أخرى فإذا وجد ذلك الحكم بـدون علـة أخــى علم أنها عديمـة التأثير وبطلت، وأمـا إذا وجـد نظير ذلك الحكـم بعلة أخـرى كان نوع ذلك الحكم معللاً بعلتين وهذا جائز. (r)

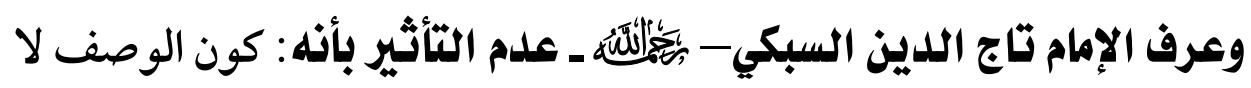

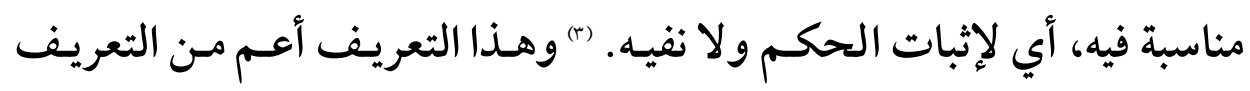
السابق، ولأجل ذلك يجعل هذا القادح مختصاً بقياس المعنى.

(1) انظر : الفائق في أصول الفقه لصفي الدين الهندي الشافعي ب/ • سب ، المحقق:

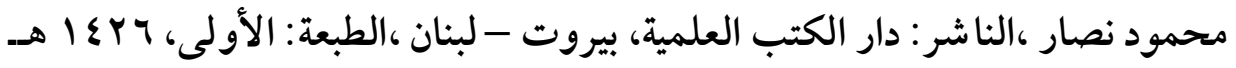
م. P. O-

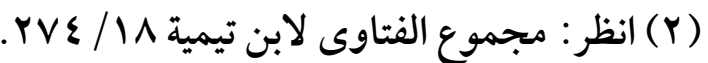

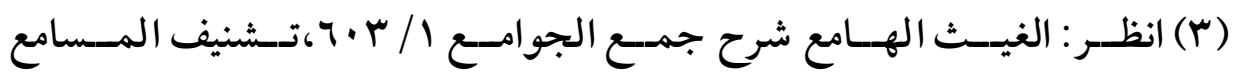

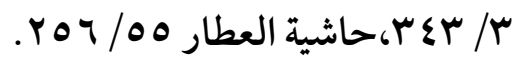


وهو: ما ثبتت فيه علية الوصف المشترك بين الأصل و الفرع بالمناسبة؛ حيث الثيث

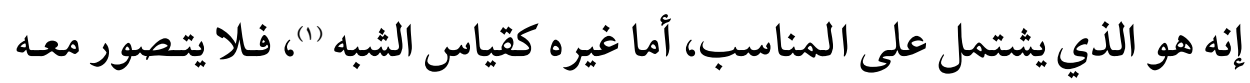

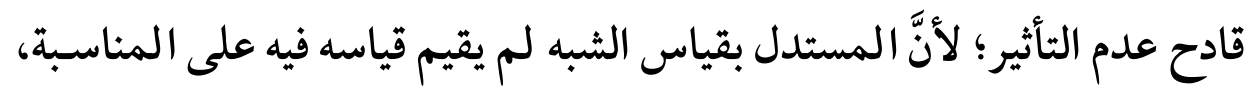
فلا يمكن أن يرد عليه هذا القادح. وعدم التأثير خاص بالعلَّة المستنبطة الاجتهادية المختلف فئل فيها، فلا يتصوَّر

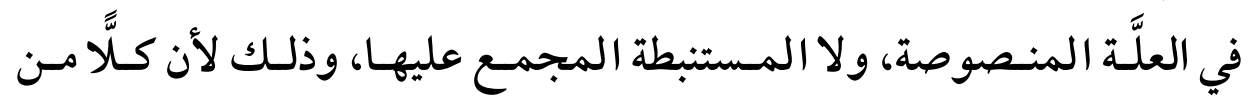

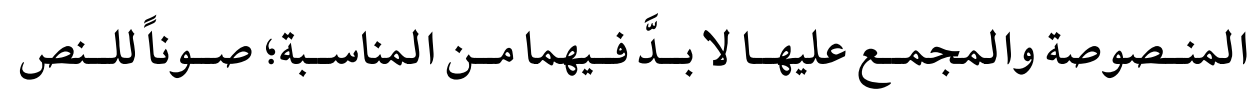

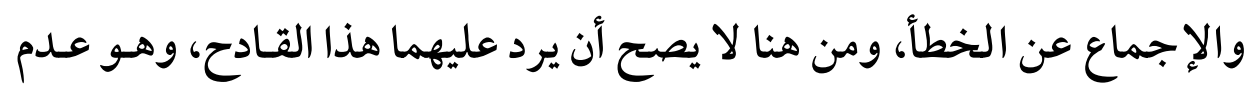
الثأثير أما المستنبطة فنظراً لكونها واردة من المجتهد، ومن فعله واستباطه فإنه يـرد عليها هذا القادح، وهو عدم تأثيرها.

(1) قياس الشبه هو: الذي يكون التعليل فيه بوصف يوهم الاشـتمال على المناسبة،

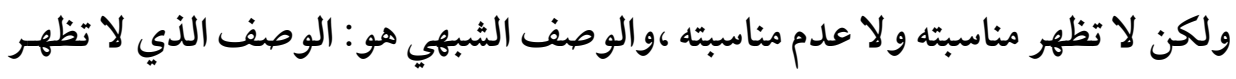
مناسبته ولكنه يوهم المناسبة. وهناك من عرف قياس الشبه بتعريف آخر فقال: هو القياس الذي يكون فيه الفرع متردداً

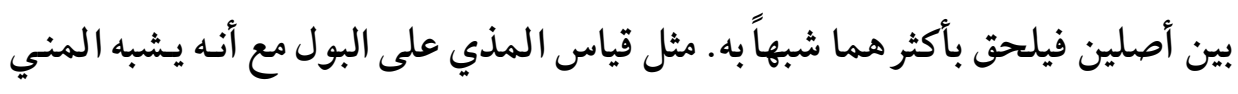

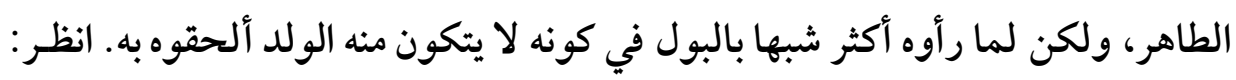

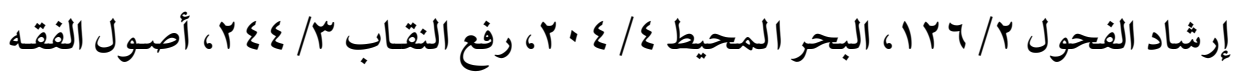

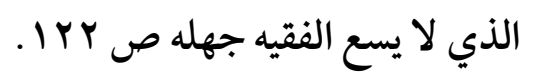

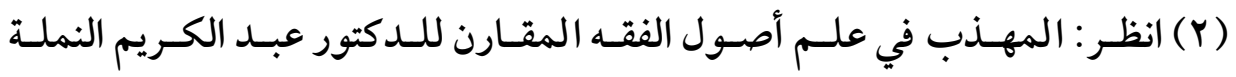




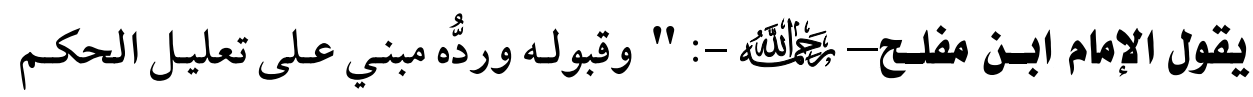

(1) "بعلتين الفرق بين علدم التأثير وعلدم العكس:

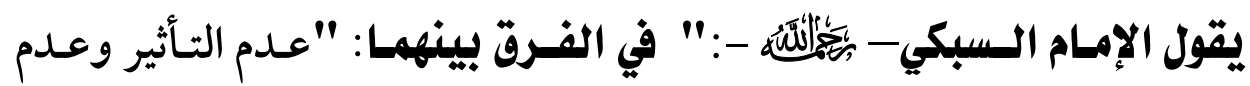
العكس مـن واد واحـد فلـذلك جمـع بيـهما، والذي عليه الجـدليون أنَّ عـدم

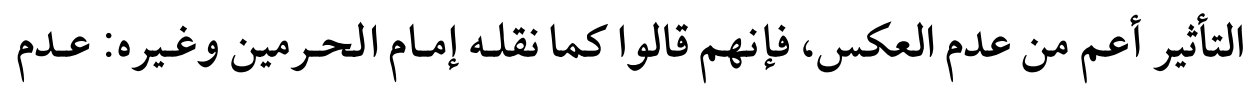
التأثير ينقسم إلى ما يقع في وصف العلـة، وإلى مـا يقع في أصلها وجعلـوا

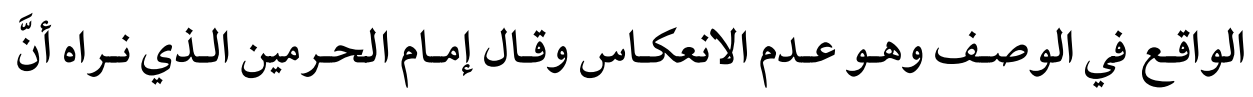
القسمين ينشآن من الأصل.

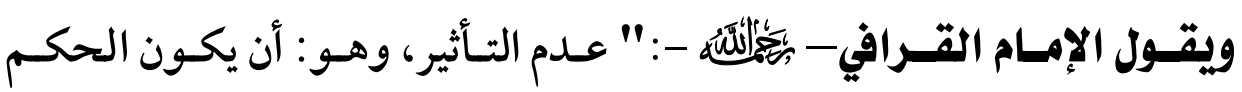
موجوداً مع وصف، ثم يُعْدم ذلك الوصف ويبقى الحكـم، فيقدح، بخـلاف " العكس ": وهو وجود الحكم بدون الوصف في صورة أخرى فـلا يقدح؛ لأنَّ العلل الشرعية يخلف بعضها بعضاً.

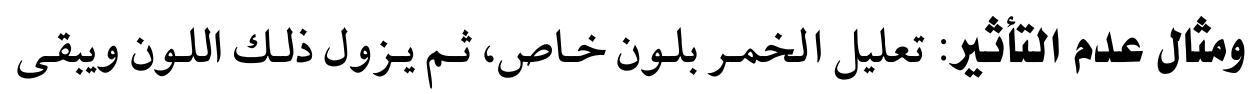

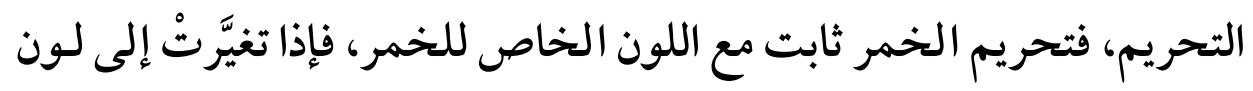

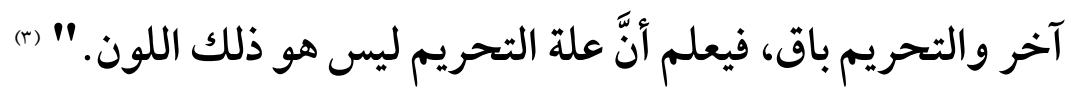

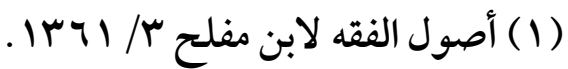
. (r) (r) الإبهاج

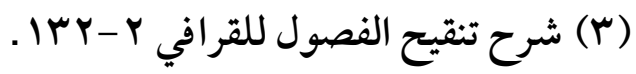


(9\&^) تعدد العلل وأثره عند الأصولييز "دراسة أصولية تطبيقية"

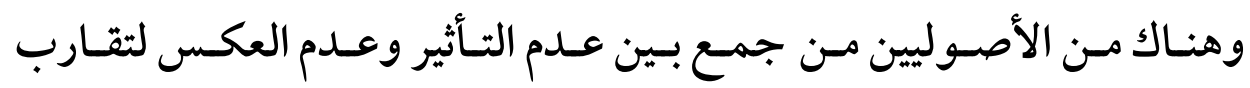
معنييهما فجعلهما قادحاً واحداً للقياس.

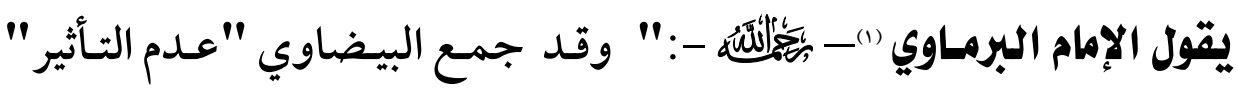

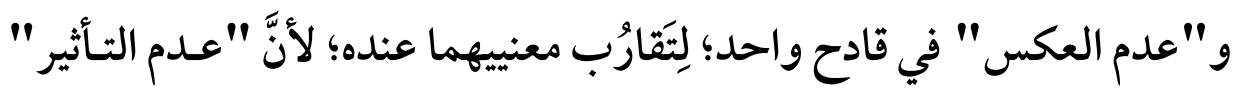
أنْ يبقى الحكـم بعـد انتفـاء الوصف في ذلـك الأصـل، و"عـدم العكس " أنْ

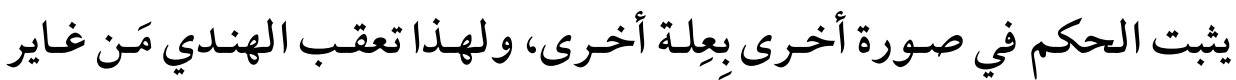

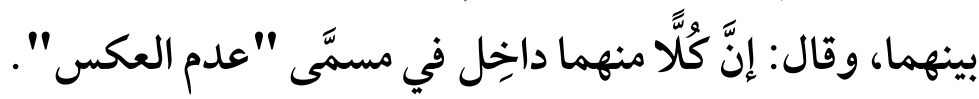

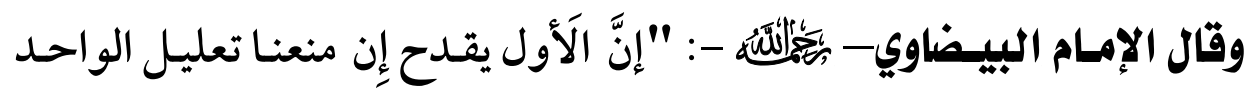

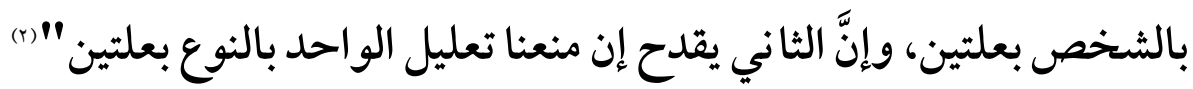

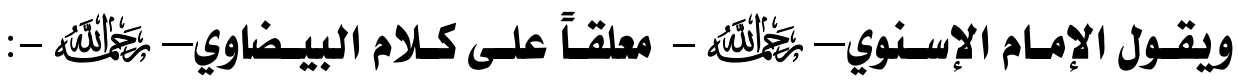
" وبنى المصنف الأول على أنَّ الحكـم الواحـد بالشخص هـل يجـوز تعليله

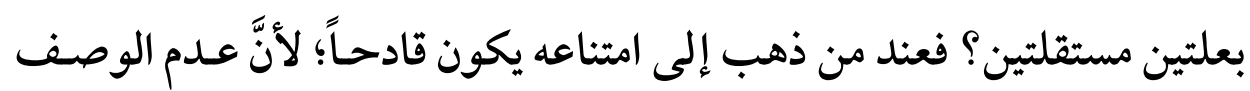

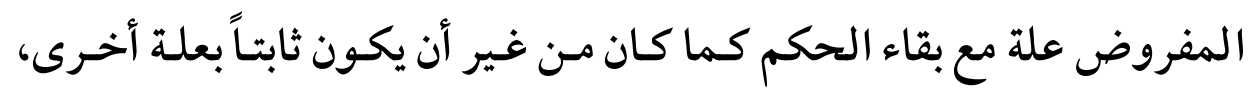

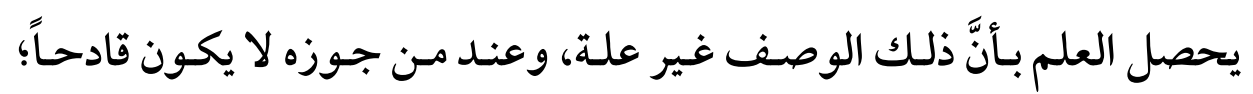

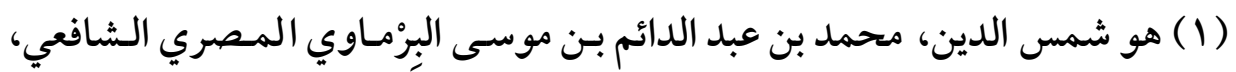

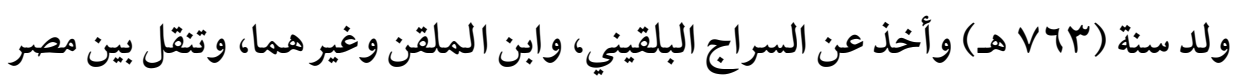

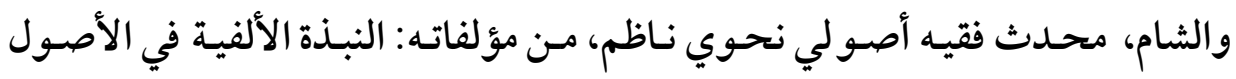

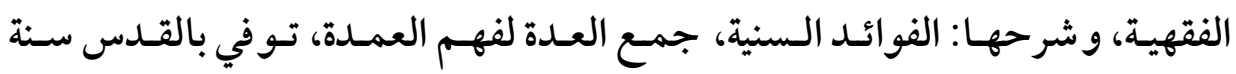

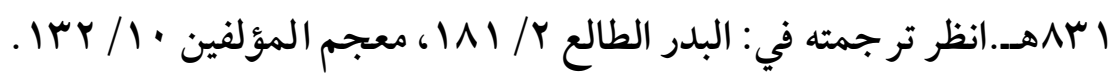

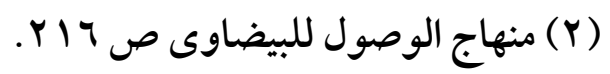


لجـواز أن يكـون بقـاء الحكــم لوصـف آخـر غـير ذلك الوصـف المفـروض لعلة." (1)

ويشترط في القدح بعلدم التأثير: أن يكون القياس قيـاس علة، فلا يقدل بـه

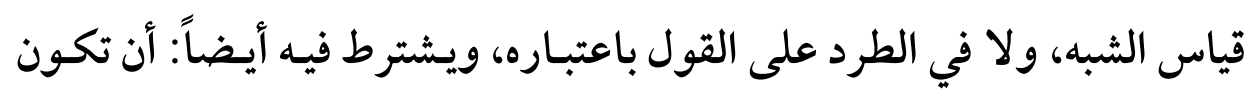
العلة مستنبطة مختلفاً فيها فلا يقدح به في علة منصوصة ولا ولا مستنبطة مجمـع عليها. (ن) وقد اختلف الأصوليون في عدم التأثير من حيث كونه قادحاً في العلية أو غير قادح فيها على مذاهب ثلاثة: المذهب الأول: يقدح مطلقاً سواء كانت العلل مستبطة مأو منصوصة.

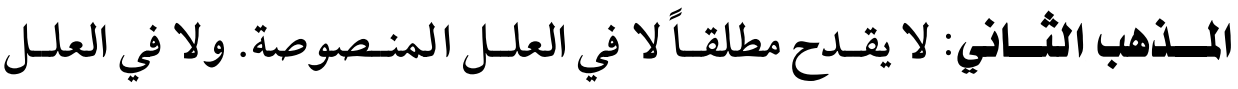
المستنبطة.

المذهب الثالث: لا يقدح في العلل المنصوصة ويقدح في العلل المستبطة. (ت) وعدم التأثير من أقوى القوادح التي ترد على القياس عند بعض العلماء.

(1) نهاية السول Y/ 199 1 ، وانظر : الفوائد السنية في شرح الألفية لشمس للبرماوي $.19 / 0$ (Y) انظر : مذكرة في أصول الفقه للشنقيطي ص بTr.

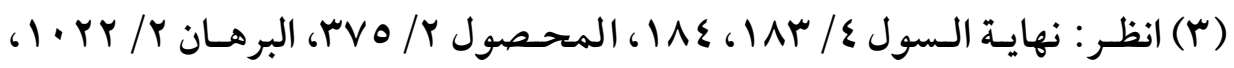

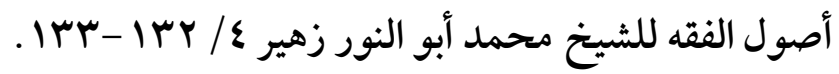


(90.)

تعلد العلل وأثره عند الأصوليين "دراسة أصولية تطبيقية"

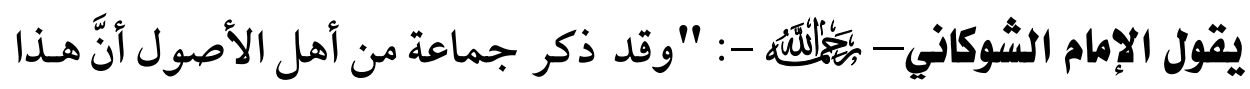

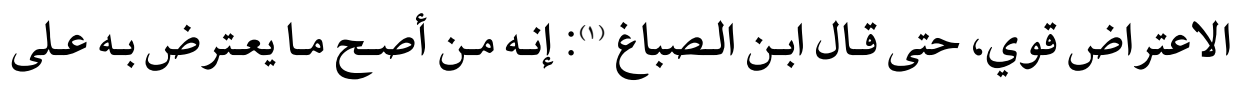
العلة". (r)

ومن العلماء من قال إنه لا حاجة له ولا يؤثر في القيـاس بعـد أن يـذكر المعلل

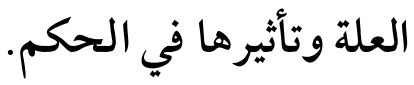

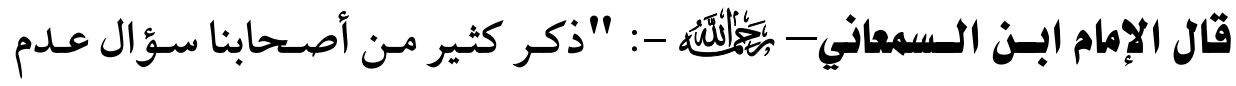

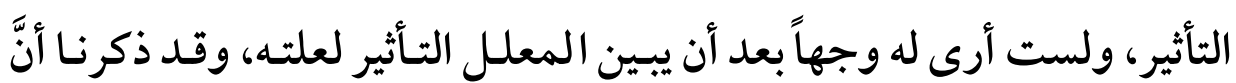

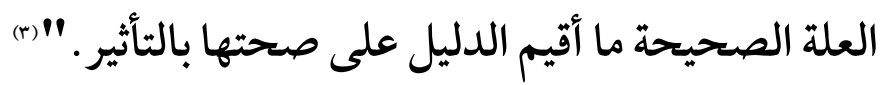

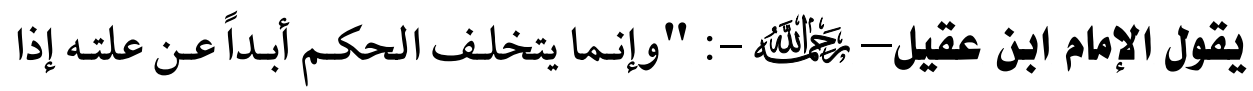
كـان ثبوتـه بعلتـين، فزالـت إحـداهما اسـتقل بـالأخرى المتخلفـة، كالـصوم والإحرام والحيض، وكل حكم ثبت بعلتين كان تخلفه جـائزاً، فأمـا مـا اتحـد موجبه فلا بقاء له مع زواله، كالحكم الثابت بالعلة الواحدة" (s).

(1) هو عبد السيد بن محمد، أبو نصر، البغدادي، الفقيه، المعروف بابن الصباغ، ولـد

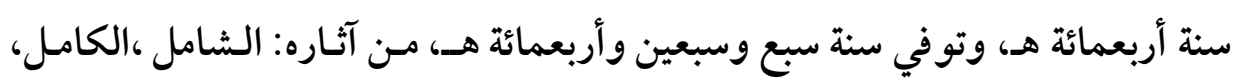

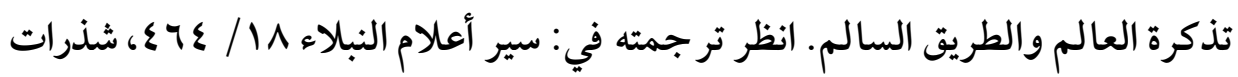

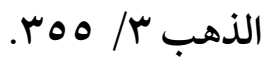

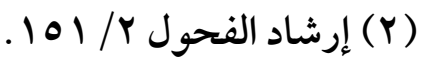

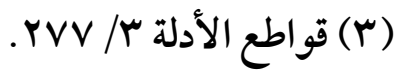

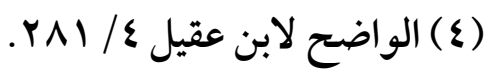




\section{المطاب الرابع}

\section{انتفاء الوصف المعارض غير المنافي للعلة}

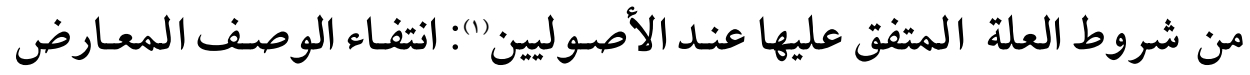
المنافي للعلة، واختلف العلماء في اشتراط الوصف المعارض غير المنافي.

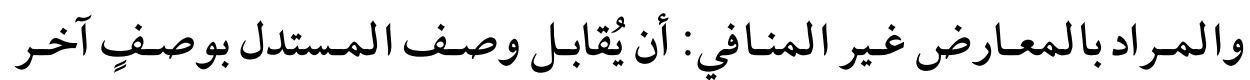

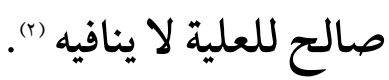

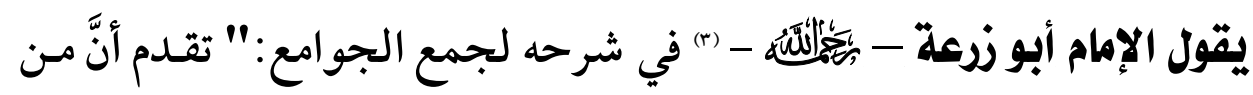

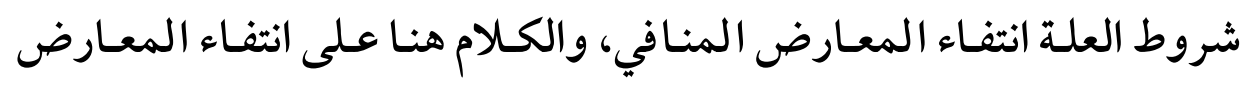

(1) هذا في العلة المستبطة، لأنَّ المنصوصة، أو المجمسع عليها، إذا قارنها أخرى

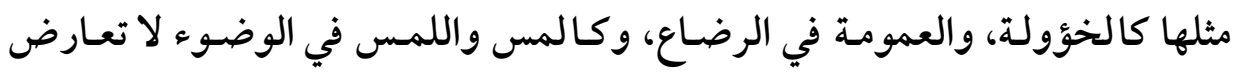

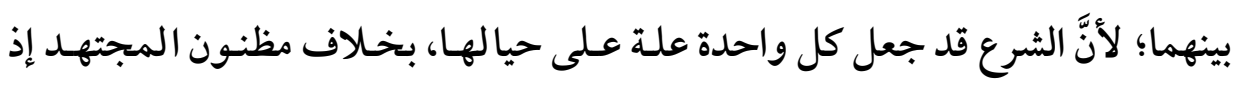

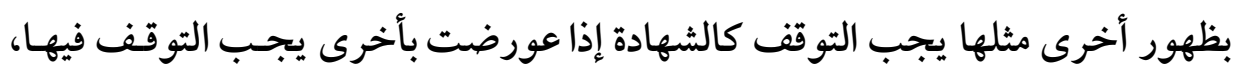

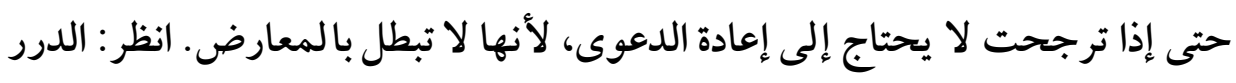

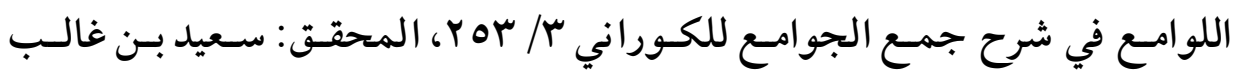
المجيدي، أصل الكتاب: رسالة دكتوراه بالجامعة الإسلامية بالمدينة المنورة، الناشر:

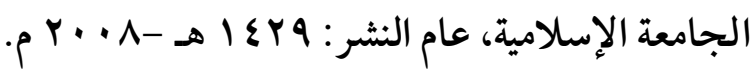

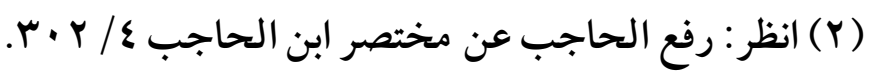

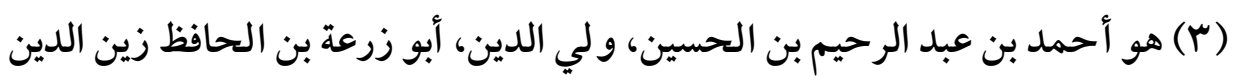

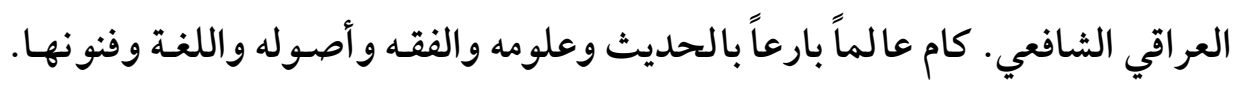

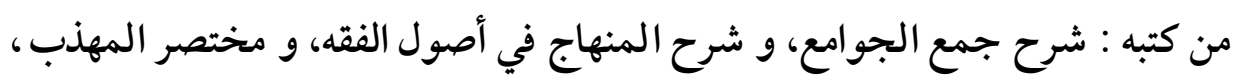


(90Y)

تعدد العلل وأثره عند الأصولييز "دراسة أصولية تطبيقية"

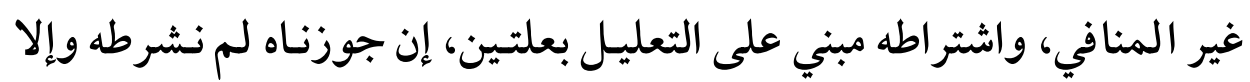

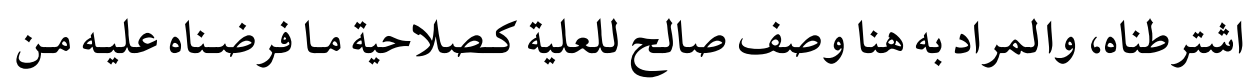

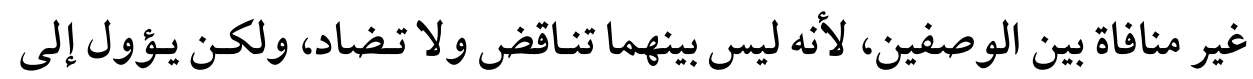
الاختلاف.

ومثالـهـ : أن يُعلل جريـان الربـا في البر بـالطعم، فيُعـارض بأنَّ العلة في ذلك الكيل، و هما وصفان اشتمل عليهما الأصل يصلحان للعلية لا منافاة بينهما في الأصل، لكن يؤول الأمـر إلى الاختـلاف بينهما إذا كـان نزاع المتنـاظرين في إلحاق التفاح بالبر في جريان الربا فيه، فإن عللنا بـالطعم شـاركه في ذلك إلك

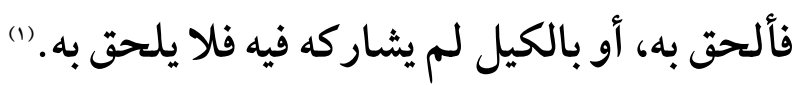

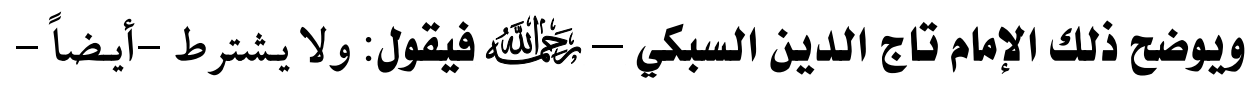

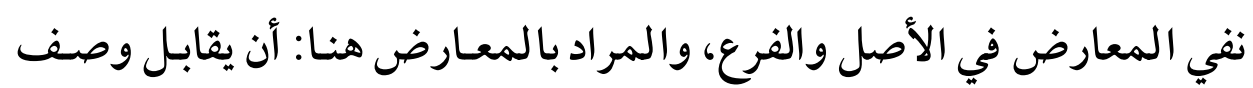

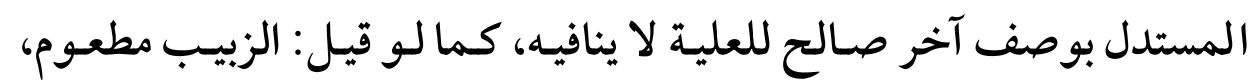

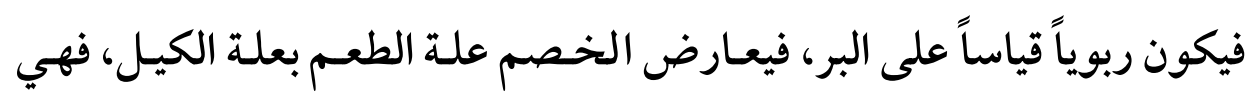

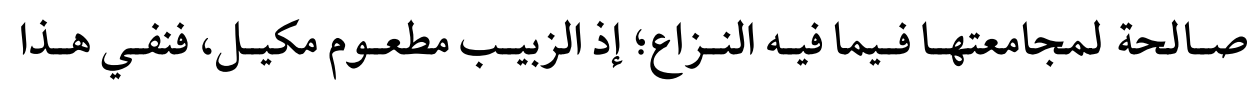
المعارض عند المصنف وسائر من يجوز التعليل بعلتين لا يشترط.

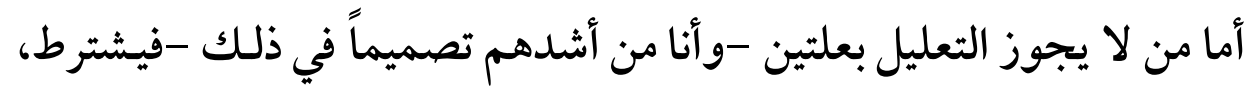
ويقول: لا بد للمستدل مـن نفي مـاعـدا الوصف المـدعي علة بطريقـة السبر

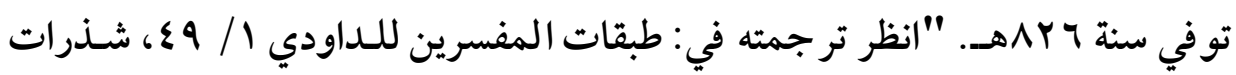

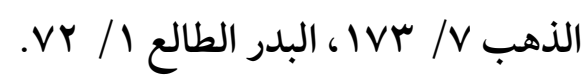

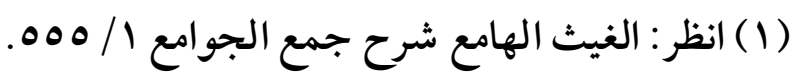


والتقسيم، وهذا ما ارتضاه إمام الحرمين، وبالغ ابن السمعاني في الرد عليه،

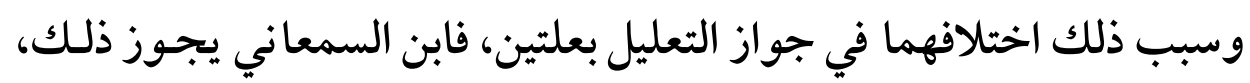

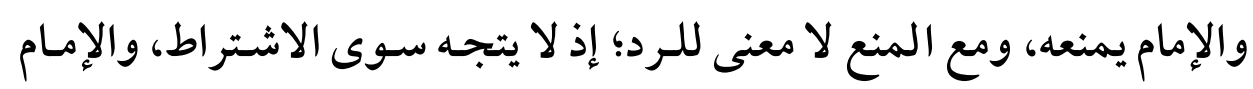
صرح بالبناء، فلا وجه للرد عليه حينئذ.

فإن قلت: ولم حمل المعارض -هنـا -على مـا لا ينافي، وهـو خلاف ظـاهر

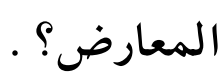
قلـت: جمعـاً بـين كلاميـه السابق، حيـث قـال: وألا يكسون بمعـارض، وهنـا، وأيضاً فمن منع التعليل بعلتين يـراه معارضـا منافياً؛ إذ لا يصح عنده التعلق بوصفين، فتسميته معارضًا عنده -تسمية حقيقية، وقـد صرح إمام الحرمين ببناء هذا على التعليل بعلتين، وكذلك الآمدي، كما عرفت (1) والراجح: هو عدم اشتراط الوصف المعارض غير المنافي بناء على ترجيح تعدد العلل كما سبق.

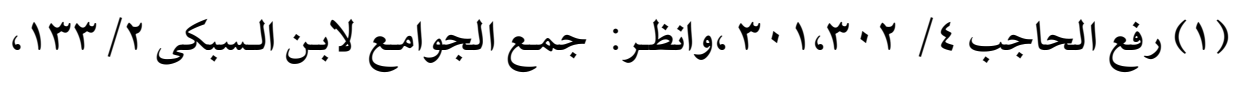

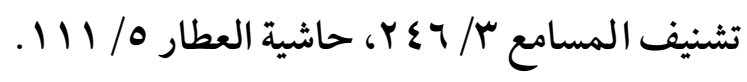




\section{الفرق أو المعارضة في الأصل بمعنى آخر}

من قوادح العلة عند بعض الأصوليين: الفرق، وهـو راجع إلى المعارضسة في الفي

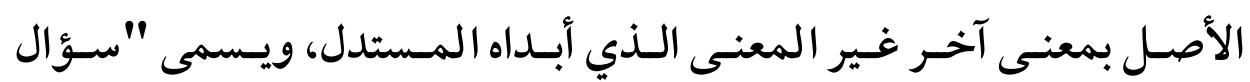
المعارضة" و "سؤال المزاحمة" فله ثلاثة ألقاب.

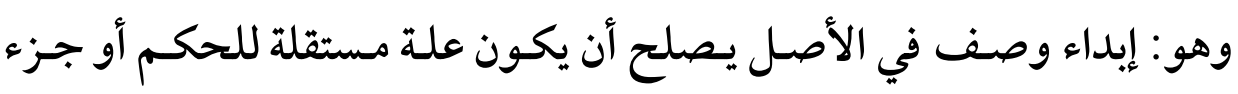

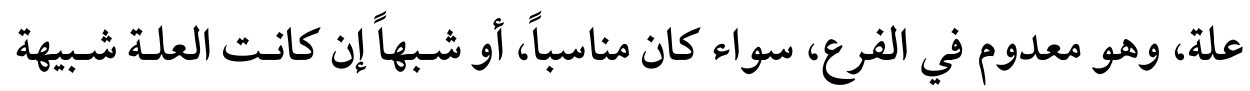

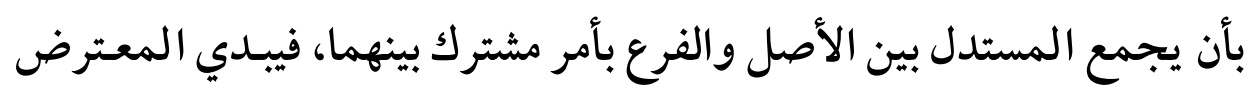

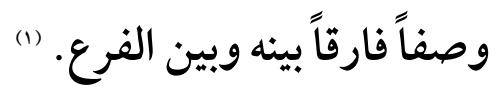

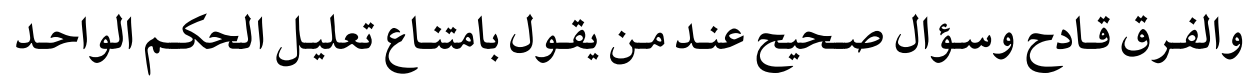

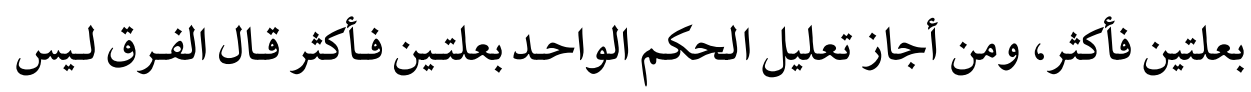
بقادح في العلة.

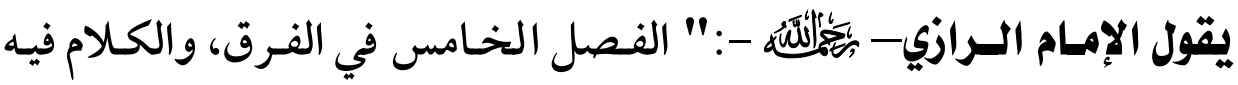

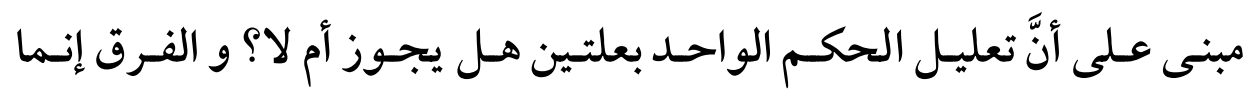

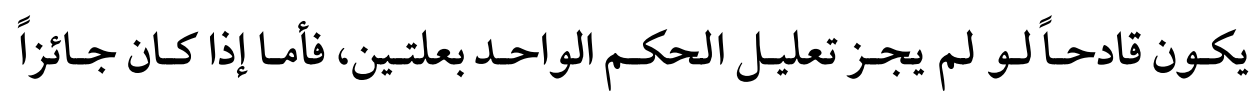

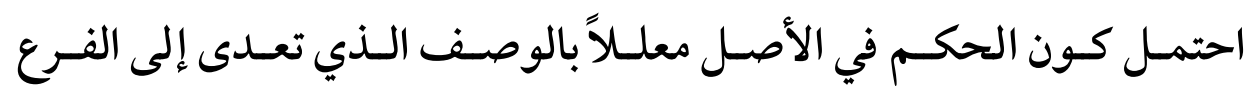
وبالوصف الذي لم يتعد إليه معاً، فلا يكون ذلك قادحاً في القياس. (r)

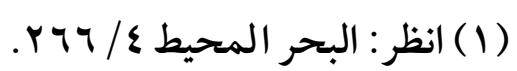

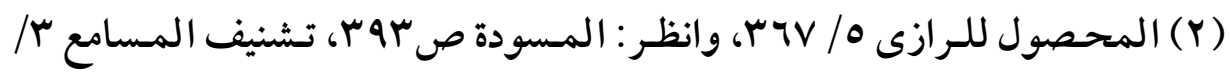

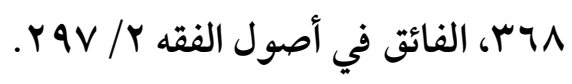


وقد اختلفت مذاهب الأصوليين في القدح بالفرق على ثلاثة مذاهب:

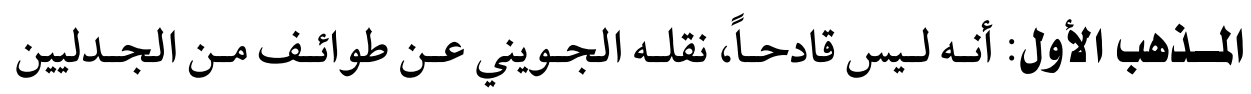
والأصوليين. المذهب الثاني: يرى أنَّ الفرق ليس سؤالاً، إنما هـو معارضـة الأصل بمعنى،

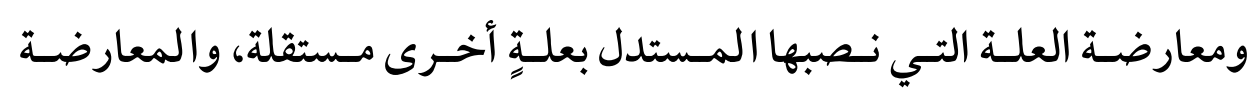
مقبولة، وهو معزوٌّ إلى ابن سريج والأستاذ أبي إسحاق الشيرازي.

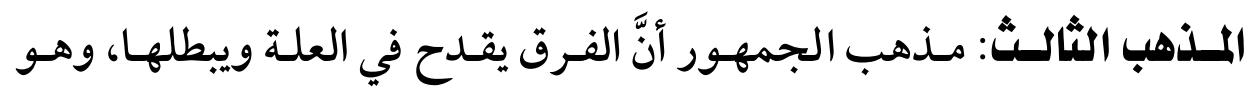
سؤال صحيح، نص الجويني على أنه مـذهب جماهير الفقهاء والمحققين، وهو الراجح ").

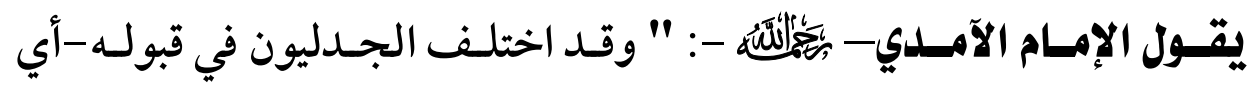
الفرق_ فمنهم من رده بناء منه على أنه لا يمتنع تعليل الحكـم الواحـد بعلتين

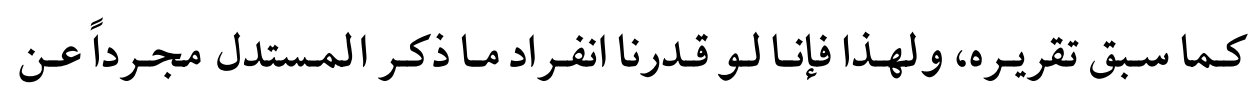

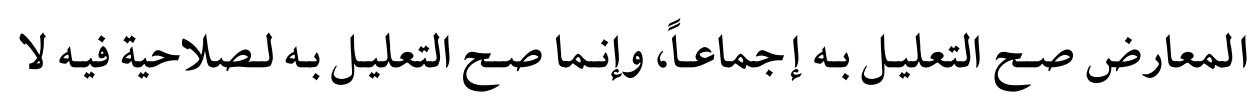

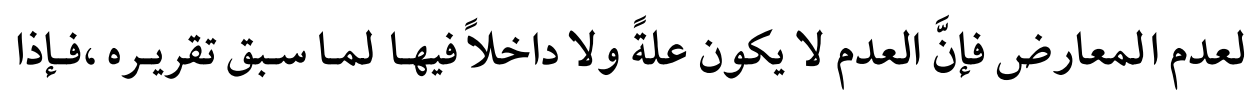
صح التعليل به مع عدم المعارض صح مع وجوده ،ولأنه لا معنى للعلة إلا ما لها

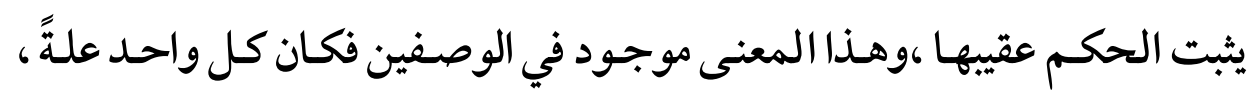

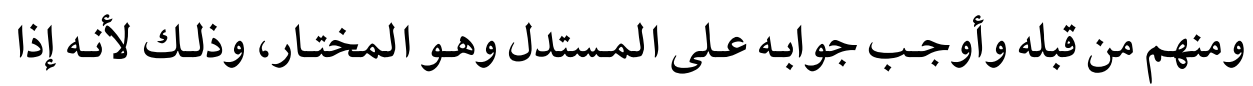

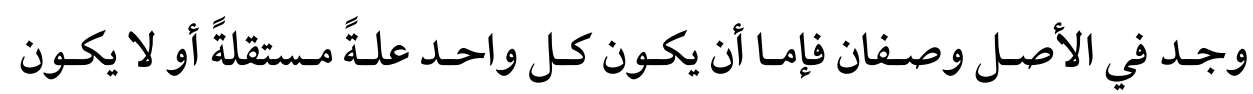

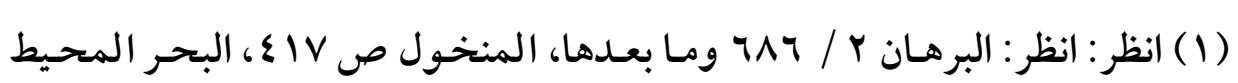

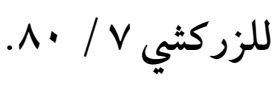


$(907)$

تعلد العلل وأثره عند الأصوليين "دراسة أصولية تطبيقية"

كذلك لا جائز أن يكون كل واحد علةً مستقلةً لما سبق تقريره في امتنـاع ذلك الكوالك سواء كانت العلة بمعنى الأمارة أو الباعث. (1)

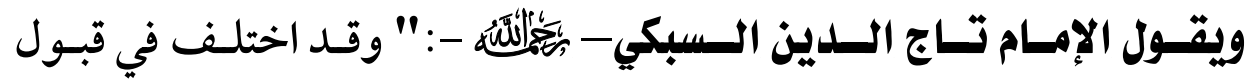
المعارضة، وبناها رادها على منع التعليل بعلتين، والمختار قبولها".

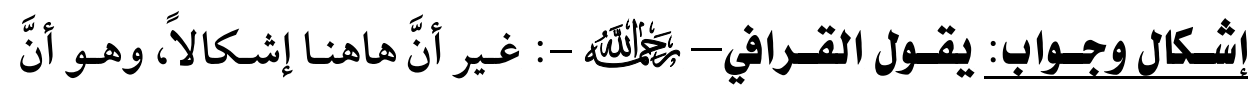
الجمهور على جـواز تعليل الحكـم بعلتين، والجمهـور على سـماع الفـرق، فيبطل قوله: إنَّ سماع الفرق ينافي تعليل الحكم بعلتين؟

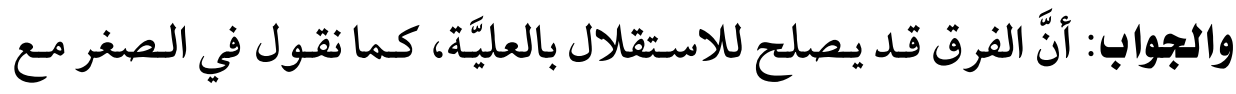

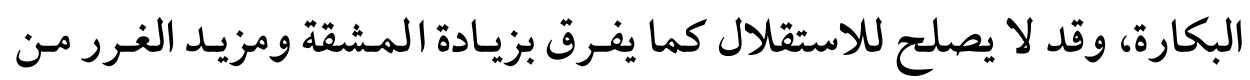
باب صفة الصفة التي لا تصلح للتعليل المستقل، فما لا يصلح للاستقلال

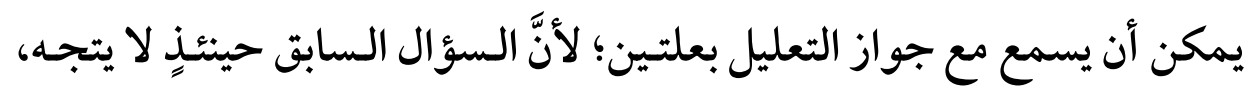
وهو الذي قال به الجمهور، وما يصلح للاستقلال لا يمكن إيـر اده إذا جوَّزنا التعليل بعلتين، فهذا تلخيص هذا الموضع أتهون.

$$
\begin{aligned}
& \text { (1) انظر: : الإحكام للآمدي r/ / 1 إ وما بعدها. } \\
& \text { (Y) رفع الحاجب § / بـ؟ ؟. }
\end{aligned}
$$

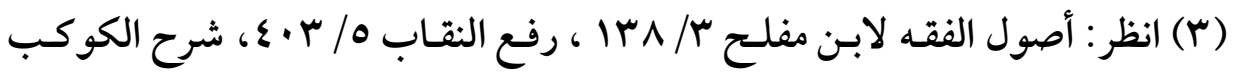

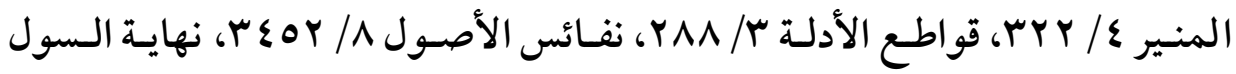

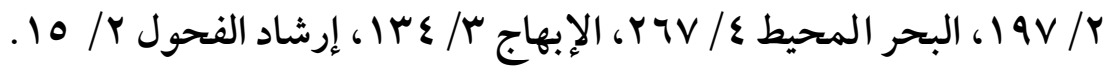




\section{المطلب السادس \\ فساد الإلغاء أو تعدد الوضع الوالئاد}

من الأسئلة الواردة على القياس عند بعض الأصوليين تعدد الوضع ومعناه: أنَ

يبدى المعترض في صورة عدم وصفه أمراً آخر يخلف الوصف الذي ألغـاه المستدل ويقوم مقامه، وسـمي تعـدد الوضـع بـذلك، لتعـد أصـل العلة فإنها

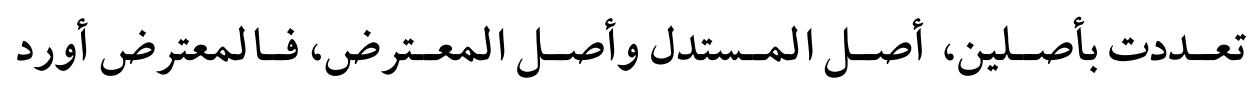

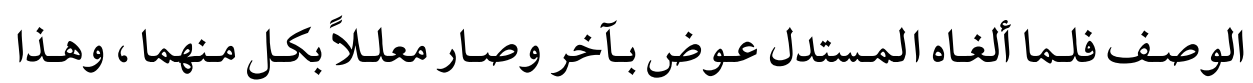
(1). السؤال مبنى على جواز تعدد العلل

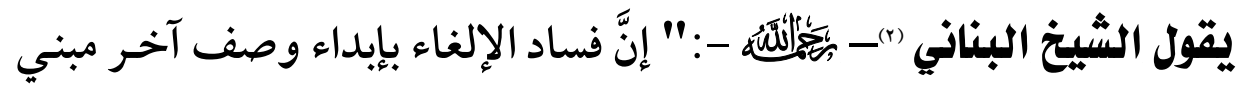

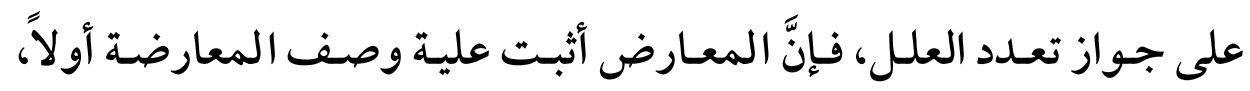

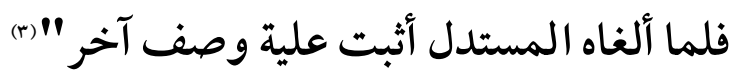

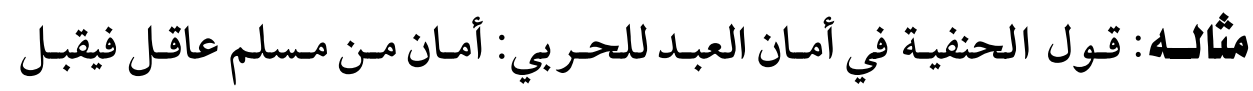

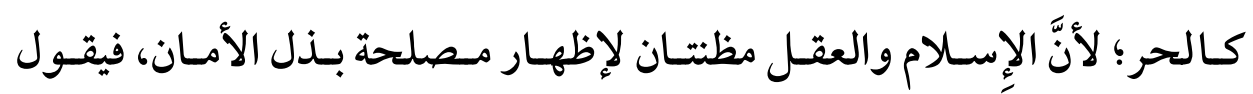

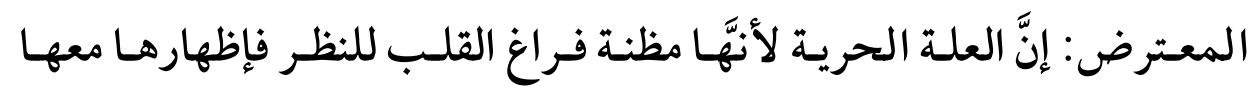

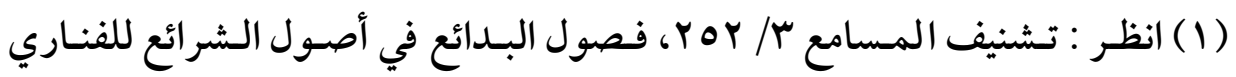
. $\varepsilon \cdot \varepsilon / r$ (Y) هو أبو يزيد عبد الرحمن بن جاد الله البناني المالكي، فقيه أصولي .من مصنفاته:

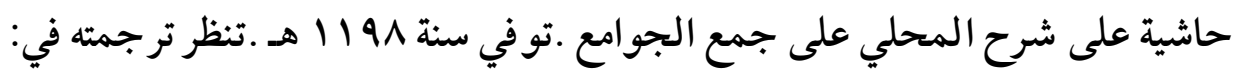

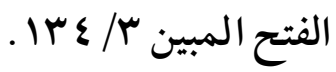

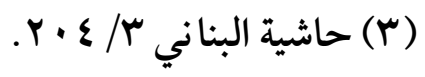


$(901)$

تعدد العلل وأثره عند الأصولييي "دراسة أصولية تطبيقية"

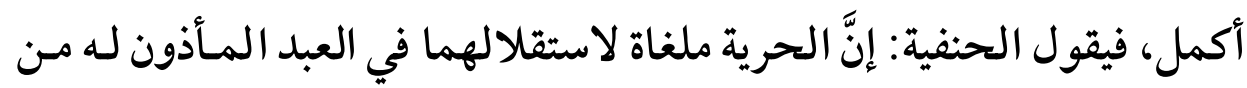

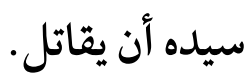
فنقول: إذن السيد لـه خلـف عـن الحريـة؛ لأنَّهـ مظنـة بـذل الوسـع في مصالح القتال أو لعلم سيده بصلاحيته لإظهار مصالح الإيمان. وجوابه: إلغاء المعلل ذلك الخلف بصورة أخرى فإن أبدى خلفًا فكـذا وهلـم الِّمان جرّا إلى أن يقف أحدهما فيكون الدبرة عليه ،فإن وجـد صسورة لا خلف فيهريه

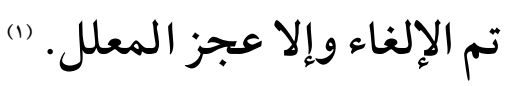

\section{الاطباب البابع}

\section{العكس}

العكس هو : انتفـاء الحكـم لانتفـاء العلة، واشـتر اطه في العلة مبني على منـع تعليل الحكم الواحد بعلتين، فمن منع تعليل الحكـم الواحـد بعلتين، اشـترط

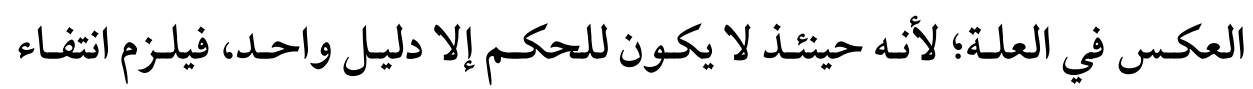

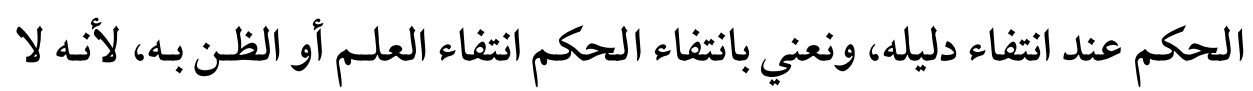
يلزم من انتفـاء الـدليل على الصانع انتفـاء الصانع، بـل انتفـاء العلمم بـه، ومـن جوز تعليل الحكم بعلتين، لم يشترط العكس في العلة، إذ لا يلززم مـن انتفـاء

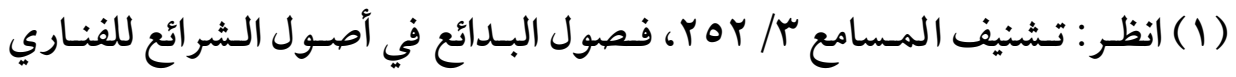

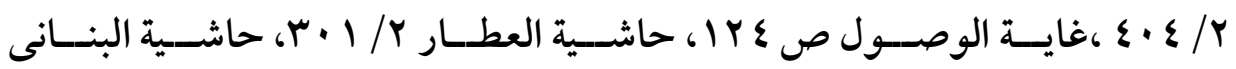

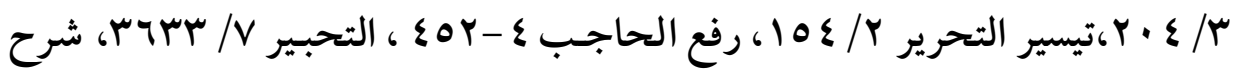

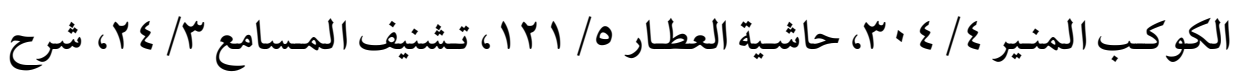

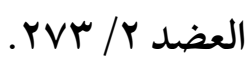


دليل انتفاء العلم أو الظن بالمدلول، لجواز تحقق دليل آخر موجب للعلم أو الظن. (1)

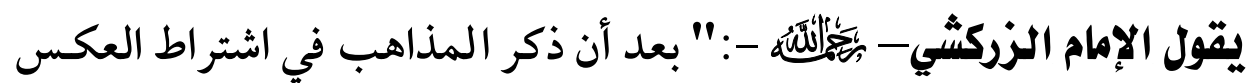

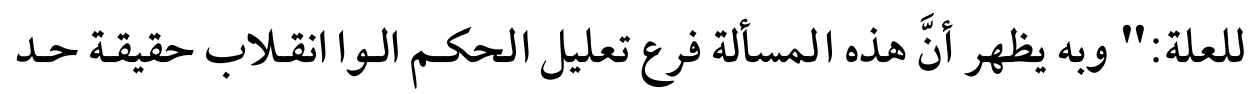
(r) "بعلل مختلفة

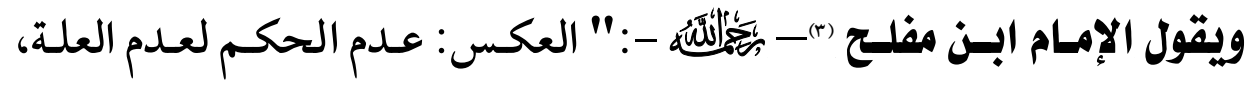
اشتر اطه مبني على منع تعليل الحكم بعلتين: فمن منعه اشترطه؛ لعدم الحكـم لعدم دليله، والمر اد بعدم الحكمي: عـدم العلـم أو الظـن بـه؛ لتوقفه عـلى النظر الصحيح في الـدليل، ولا دليل، وإلا فالصنعة دليل وجـود الصانع، ولا يلزم مـن عـدمها عدمـه ، ومسن جـوزه لم يـشترطه؛ لجـواز دليل آخـر، هـذا إن كـان التعليل لنوع الحكم، نحو: الردة علة لإِباحة الدم". فأمـا لجنـسه فـالعكس شرط، نحـو: "الـردة علـة لجـــس إِاحـة الـدم"، فـلا يصح؛ لفوت العكس ، وظاهر ما سبق: أنَّ الخلاف في تعليل الحكـم الواحـد

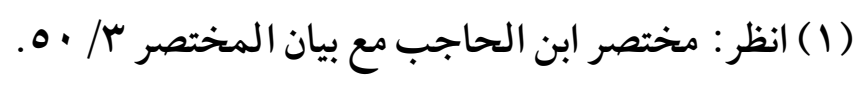

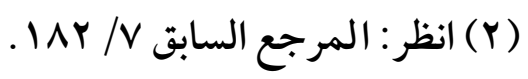
(r) هو شمس الدين أبو عبد الله محمد بن مفلح بن محمد بن مفرج المقدسي الحنبلي

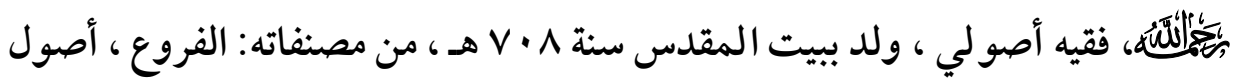

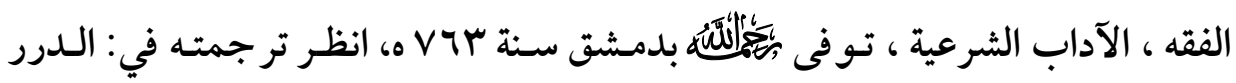

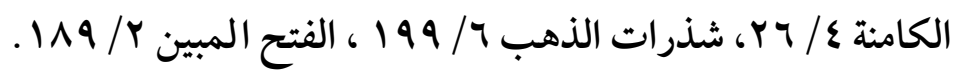


(97.)

تعلد العلل وأثره عند الأصولييز "دراسة أصولية تطبيقية"

بعلتين معـاً وعـلى البـدل ،وكـذا لم يقيـد جماعـة المسـألة با لمعيـة، وقيـدها الآمدي (1) وقال في العكس: "أثبتـه قوم، ونفاه أصسابنا والمعتزلة"، ثم اختار: أنه إنما يكون معللاً بعلة على البدل، فلا يلزم من نفيها؛ لجواز بدلها.

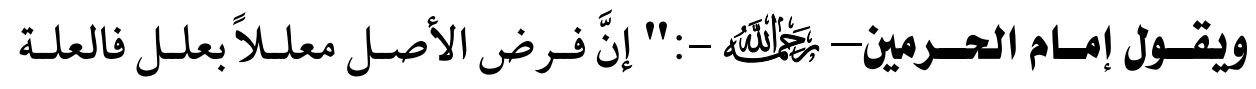
الواحـدة لا يتضضمن انتفاؤهـا انتفـاء الحكـم، وهـذا منشؤه مـن تعـدد العلـة في الأصل ،وإن اتحدت العلة جر ذلك الانعكاس" (r). وقد اختلف الأصوليون في القدح في العلة بعدم الانعكاس (s).

$$
\begin{aligned}
& \text { (1) انظر : الإحكام للآمدي ץ/ ع سץ، و ما بعدها. } \\
& \text { (r) أصول الفقه لابن مفلح r/ / ا ا و م ما بعدها }
\end{aligned}
$$

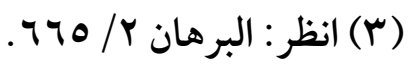

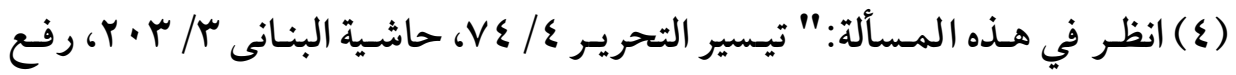

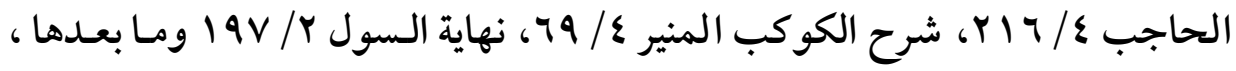

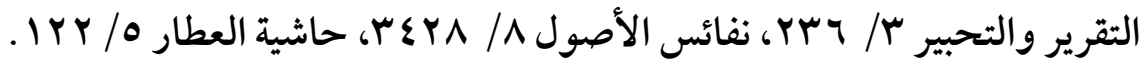




\section{الإطلب الثاهن}

\section{الوصف الذي جعل ضابطاً لمكمته يجب أن يكون جامعاً لالمكمة}

هذا الشرط عند بعض الأصوليين في حكمة العلة ،وهو بناء على الخلاف في حكم تعدد العلل.

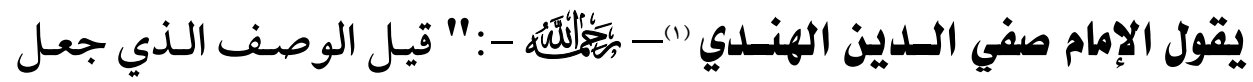

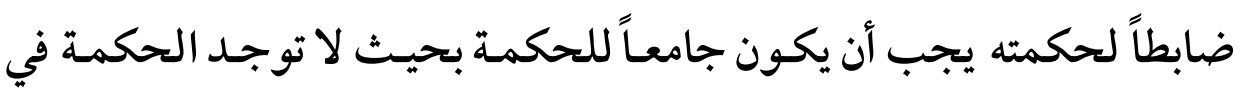

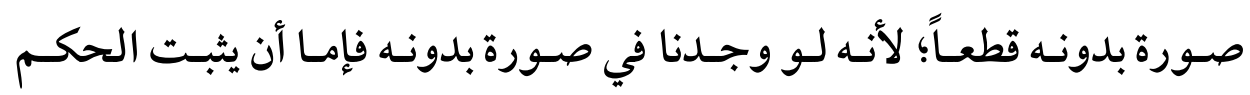
المرتب على الضابط المشتمل عليها في تلك الصورة، أو لا يثبـ، فإن كـان الأول لزم أن تكون الحكمة هي العلة دون الضابط، وأنه يكون مستغني عنه؛

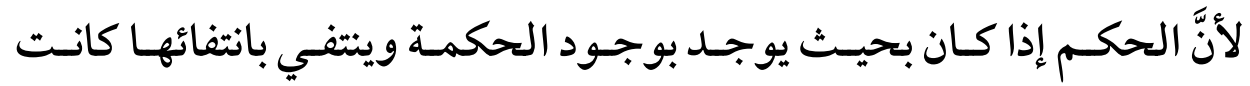
الحكمة هي العلة ويكون الضابط مستغني عنه فيمتنع نصبه ضـابطاً، وإن كان إنان

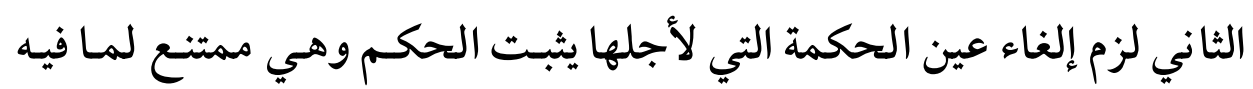
من عدم اعتبار المقصود الأصلي واعتبار الفرع الذي هو غير مقصود.

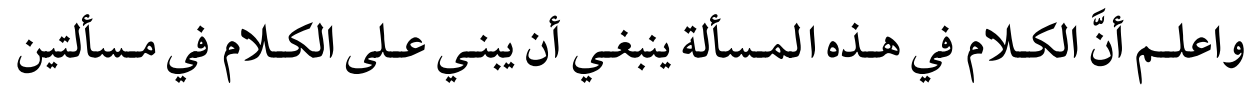

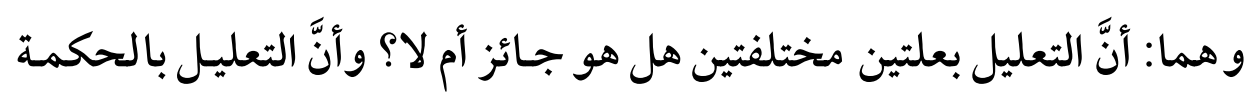
المجردة عن الضابط هل هو جائز أم لا؟

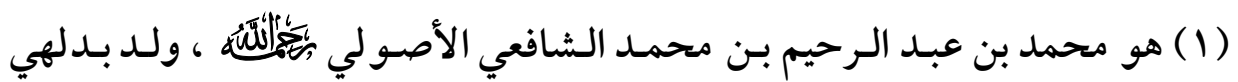

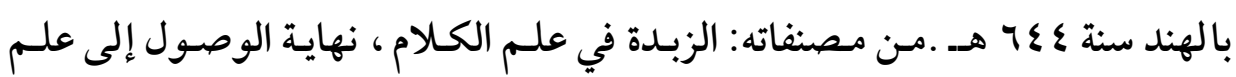

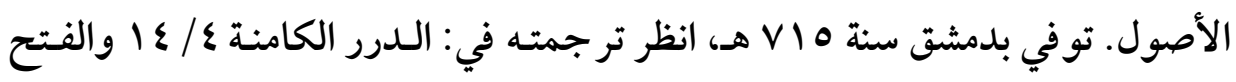
المبين r/ • إ. 
فمن جوز ذلك لزمه تجويز ما نحن فيه، ولا يتأتى عليه الدليل المـذكور، ومـن فئن لم يجوز ذلك لزمه امتناع ما نحن فيه لتأتى الدليل المذكور عليه. مثاله: ضبط الحنفية العمدية باستعمال الجارح، فإنه يلزم منه إهمـال العمديـة مع تيقن وجودها ، وذلك فيما أصاب رأس الإنسان بـصخرة عظيمـة، أو ألتـاه في بحر مغرق أو نار محرقة لا خلاص منها. هذا: وقد اختلف الأصوليون في التعليل بنفس الحكمة المقصودة مـ شرع الحكم، كالرضى في البيع، والمشقة في السفر، وحفظ الـنفس وغيرهـا على

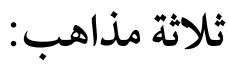
المذهب الأول: يجوز التعليل بالحكمة مطلقاً، سواء كانت منضبطة، أو غير منضبطة، ظـاهرة كانـت أم خفية، واختـار هـذا القـول الإمامـان الفخر الرازي والبيضاوي -ـرحمهما الله-. ودليلهما وجهان:

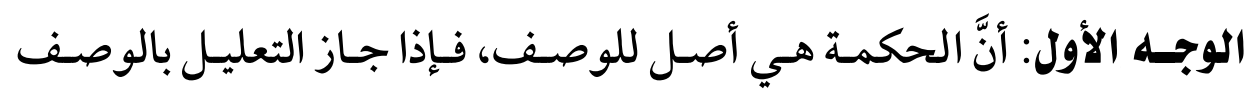
فأولى وأحرى أن يجوز التعليل بالحكمة، لأنها أصله .

(1) نهاية الوصول في دراية الأصسول لصفي الدين الهندي ^/ • هـهـ، المحقق: د. صالح بن سليمان اليوسف - د. سعد بن سالم السويح ،أصل الكتاب: رسالة دكتوراه

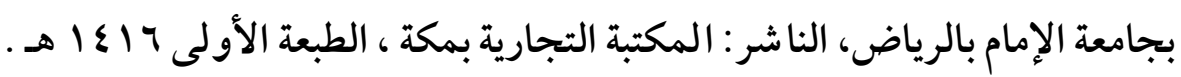

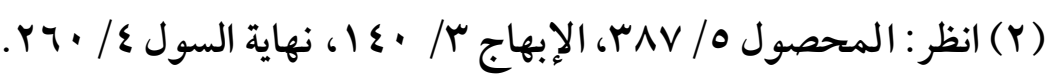


الوجه الثاني: أنَّ الحكمة هي نفس المصلحة والمفسدة، وهي سبب ورود الشرائع، فالاعتماد عليها أولى من الاعتماد على فرعها (1).

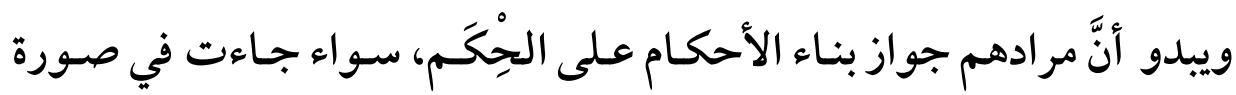

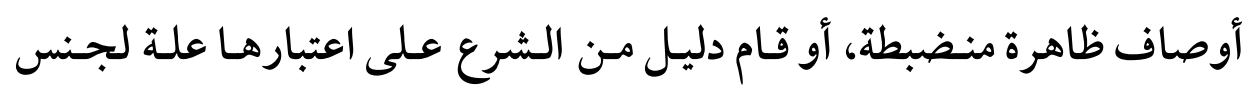
الحكم أو عينه في كل موضـع، أو جـاء التعليل بتلك الحكمة في موضـع مـا مـع عـدم ضـبطها بوصـف ظـاهر، وهـؤلاء هـم الـذين يجيـزون الاسـتدلال

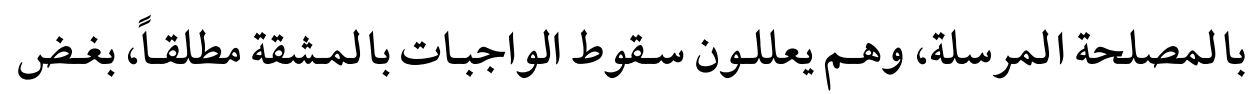
النظر عن سبب المشقة، ويعللون الوجـوب بالمصلحة الحقيقيـة العامة أو

$$
\text { الحاجة أو الضرورة. }
$$

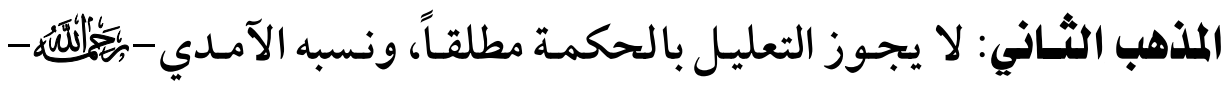
لأكثر العلماء.

\section{وحجتهم في ذلك:}

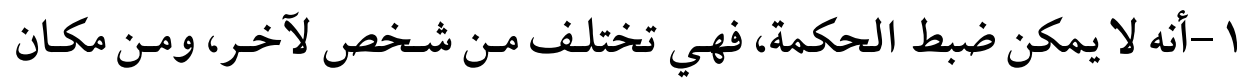

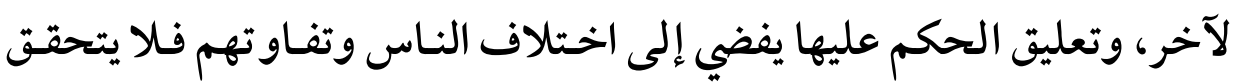

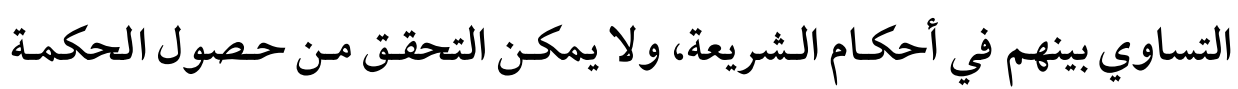

$$
\text { حتى يرتب الحكم عليها. }
$$

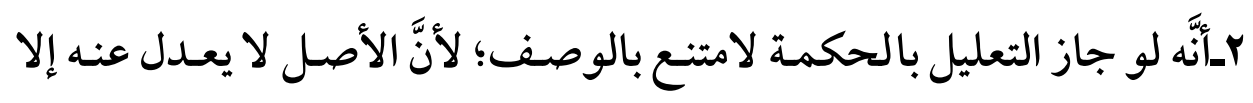
عند تعذره، والحكمة ليست متعذرة، فيجب التعليل بها، فإذا علل بها امتنع 
(97६)

تعدد العلل وأثره عند الأصولييز "دراسة أصولية تطبيقية"

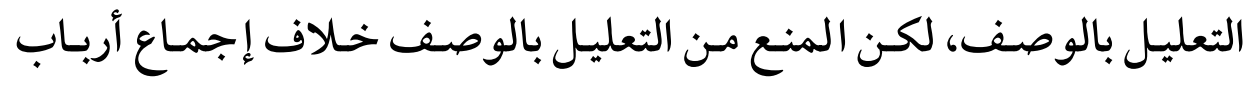

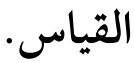

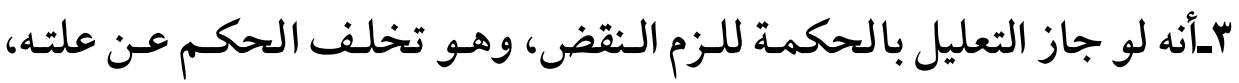

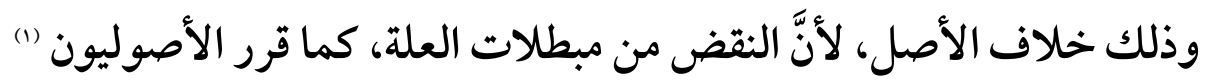

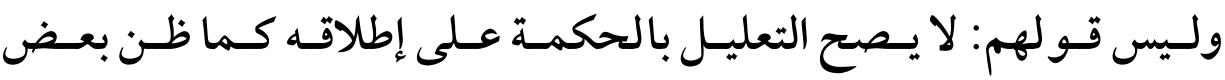
المحدثين، فأخذ يستدل بما ورد في القر آن والسنة من تعليل بالحكمـة، وإنـما مر ادهم عدم جـواز التعليل الذذي يبنى عليه قيـاس، وجعلوا تلك التعليلات الواردة في الكتاب والسنة قاصرة غير متعدية، فلا يمكن أن يبنى عليها حكـم ئم جديد. (r)

المذهب الثالث: أنه يجـوز التعليل بالحكمة الظاهرة المنضبطة بنفسها، أمـا الخفية المضطربة، فلا يجوز التعليل بها، وهو اختيار الآمـدي ، وهؤلاء مـع

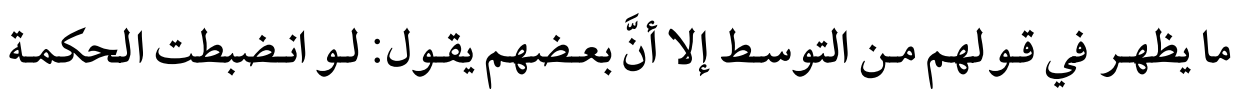
جاز التعليل بها لكنها لا تنضبط. والجق: أنها إن انضبطت بضابط معين نص الشرع عليه، أو قـام عليه إجماعاع، أو دل عليه دليل مقبول من أدلة ثبوت العلة، فلا خلاف في جواز التعليل بها،

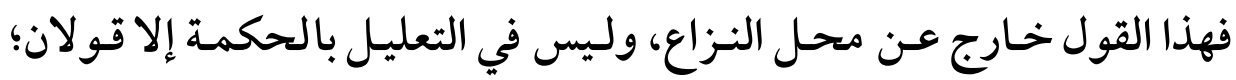

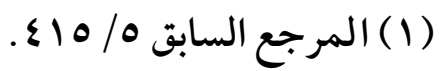

(Y) انظر : أصول الفقه الذي لا يسع الفقيه جهله ص •11. 
(970)

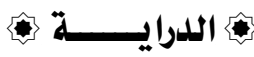

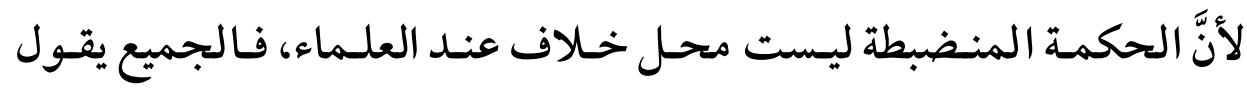

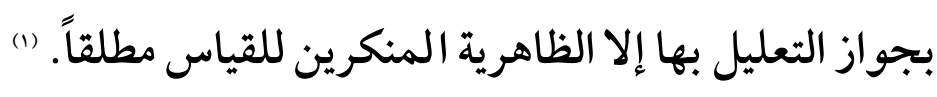

\section{الإطلب التاسع}

من شروط الفرع: ألا يكون هنصوصًاً عليه لا إثباتًا ولا نفيًا

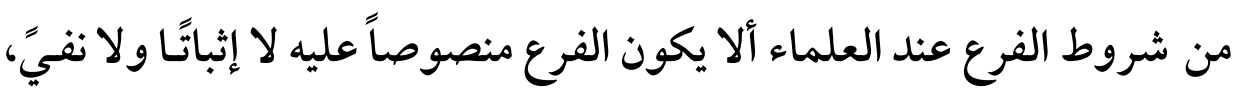
وهذا الشرط مبنى على الخلاف في حكم تعدد العلل.

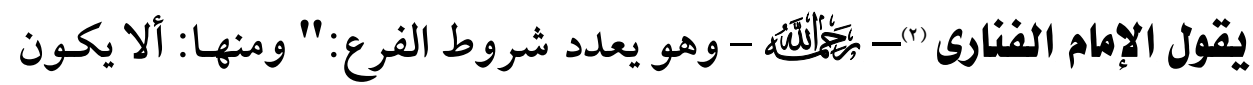

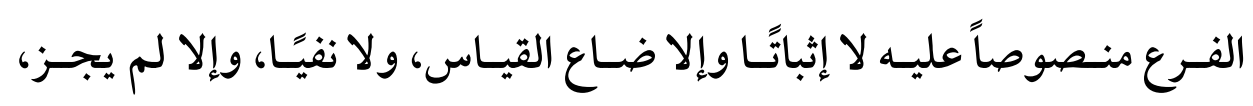

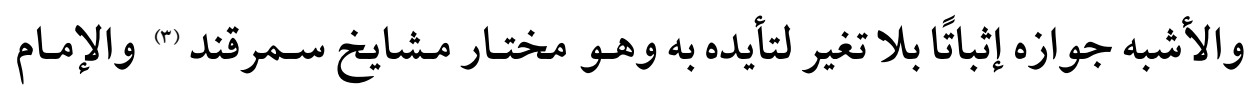

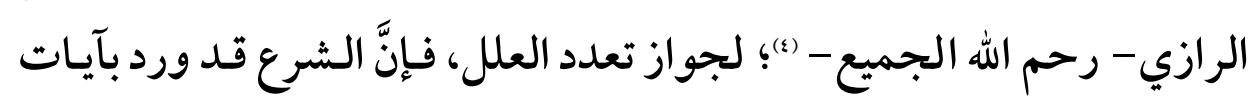

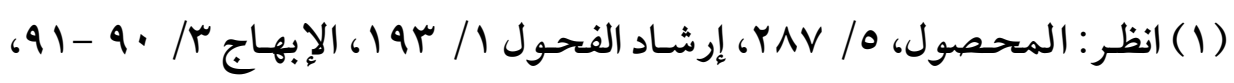

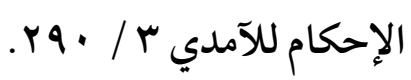

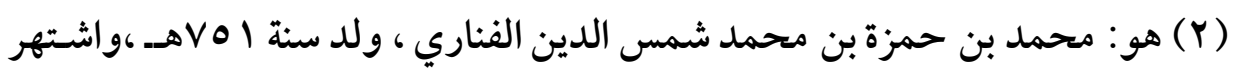

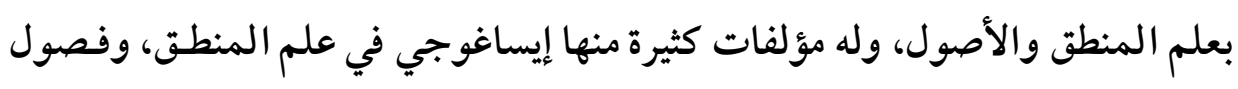

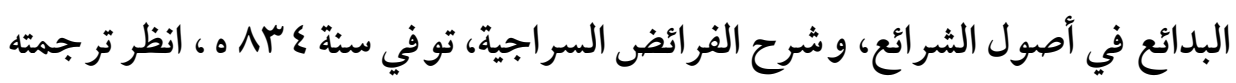

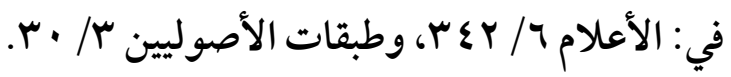

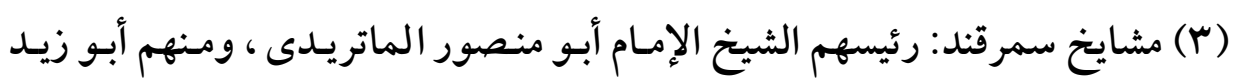

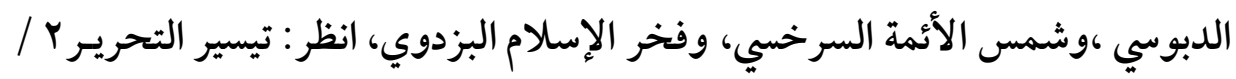

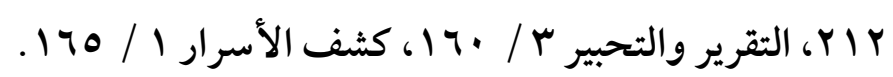
( ) بل شرطوا أن لا يثبت القياس زيادة على النص، وقيل هذا القول أشبه فإِنَ فيه تأكيد النص ولا مانع شرعاً وعقلاً 
(977)

تعدد العلل وأثره عند الأصولييين "دراسة أصولية تطبيقية"

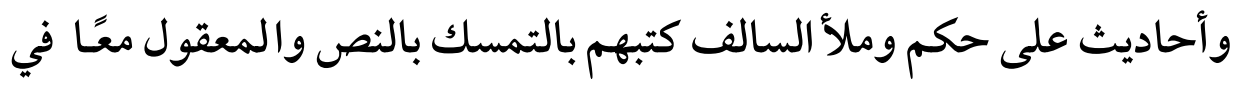
حكم، ولم ينقل عن أحد نكير، فكانا إجماعاً على جوازه". "(1).

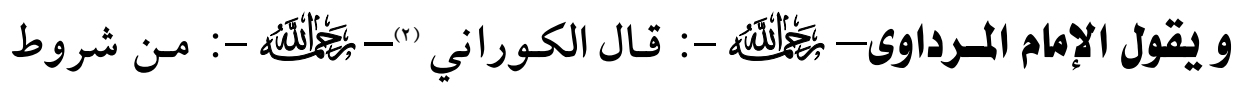

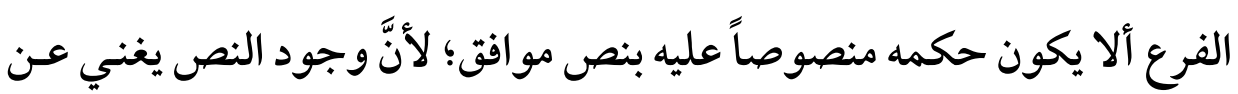

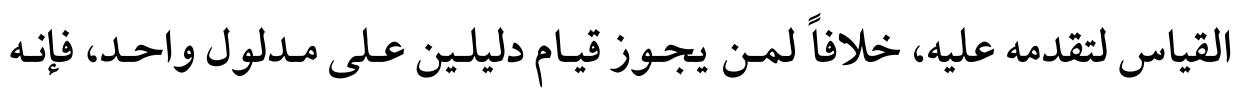
يجتمع عنده النص والقياس على حكم واحد.

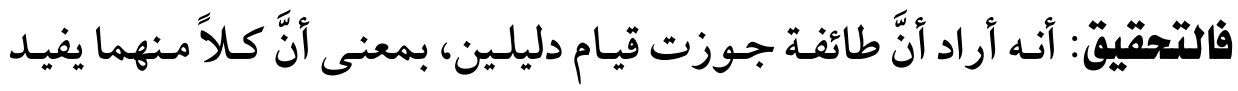
العلم بالمدلول فهـا غير معقول؛ لأنه تحصيل الحاصل، وإن أراد إيضاحاً

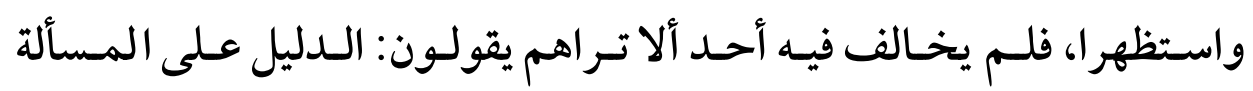

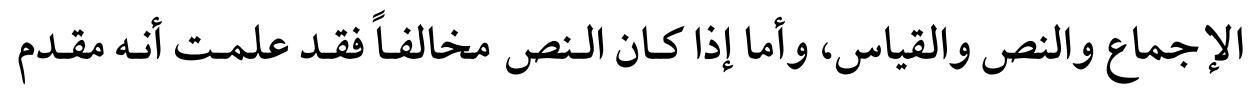
على القياس " (r).

من تعاضد الأدلة وتأكيد بعضها ببعض، انظر : تيسير التحرير ץ/ سـ؟ التقرير والتحبير .

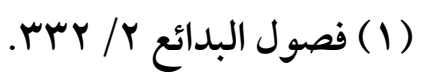

(Y) هو: شهاب الدين أحمد بن إسماعيل بن عثمان بـن أحمــ بـن رشيد بـن إبـراهيم

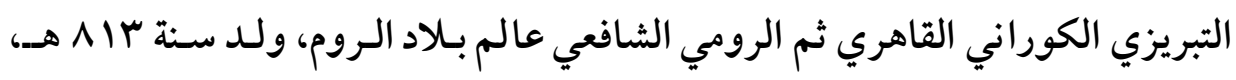
بقرية كوران، وتميز في الأصلين والمنطق والفقه وغيرها، وكان قاضي قضاة عساكر بركي

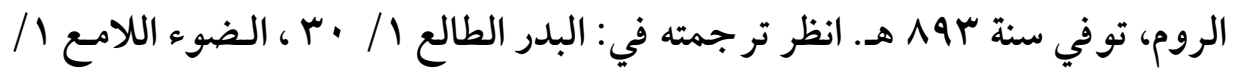




\section{المطلب العاشر}

\section{هن شروط العلة: أن تكون هتمدة في الأصل}

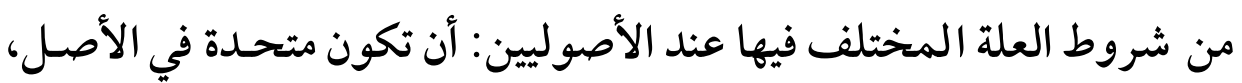

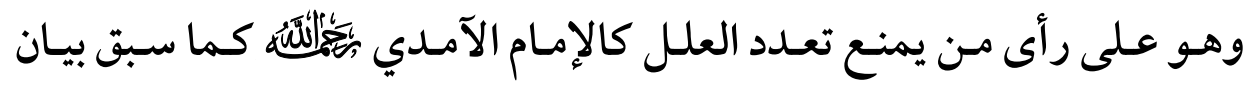
ذلك.

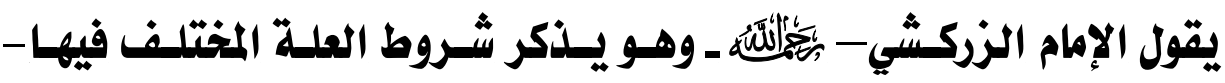

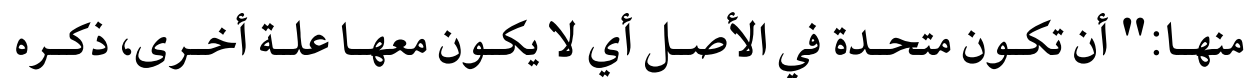

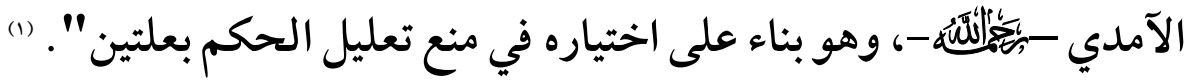

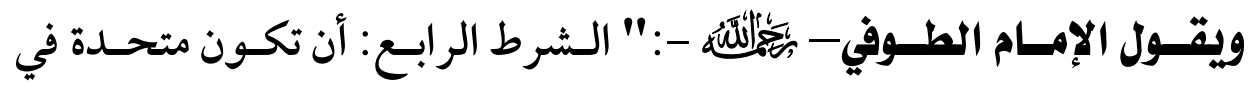
الأصل، أي: لا يكون معها فيـه علـة أخـرى، وذكر كلاماً طويلاً موضعه عند (") 


\section{الخاتمة}

الحمد لله الذي تتم بنعمته الصالحات وتقضى الحاجـات، والحمـد لله الـذي

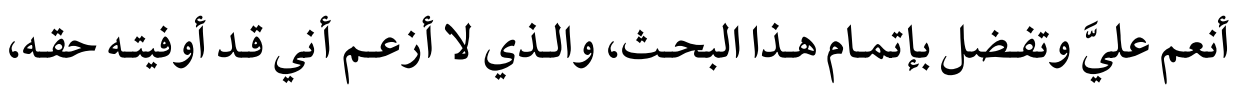
ولكنه جهد المقل المقصر؛ فما كان فيه من حق وصواب فمـن الله عز وجلـ،

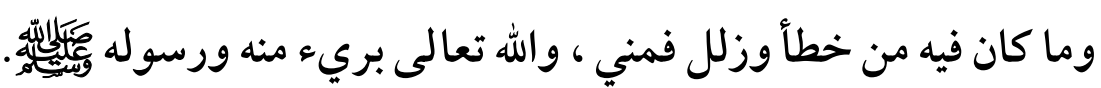
هذا وقد أسفر البحث عن النتائج التالية:

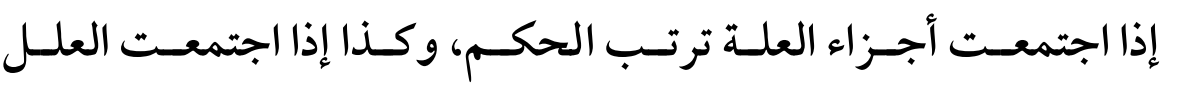

$$
\text { المتعددة ترتب الحكم، ولكنهما ليسا بمعنى واحد. }
$$

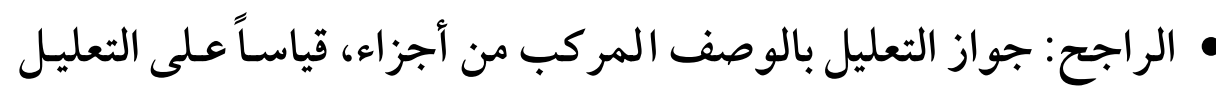

$$
\text { بالوصف الواحد. }
$$

مذهب الجمهور جواز تعدد العلل الثرعية لحكم واحـد، وذلك لوروده

$$
\text { ووقوعه في الشرع والأمثلة على ذلك كثيرة. }
$$

• تعدد العلل لحكم واحد يزيد الحكم قوة وتأكيداً.

$$
\text { عند تعدد العلل تكون كل واحدة علة مستقلة لا جزء علة. }
$$

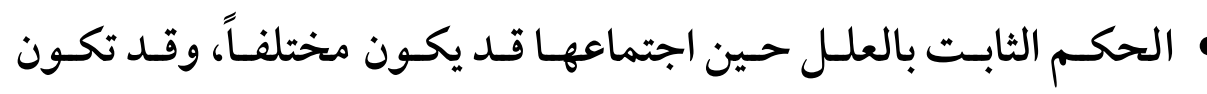

$$
\text { الأحكام متماثلة. }
$$

• الراجح: جواز تعليل الأصل بالعلة التي لا تدل على حكم الأصل.

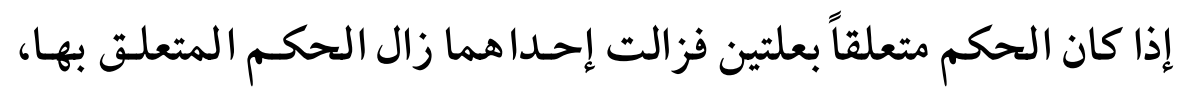
وبقي الحكم متعلقاً بالعلة الأخرى. 
(979)

• لا فرق في التعليل عند تعليل الحكم بعلتين إحدى العلتين فروعها أكثر

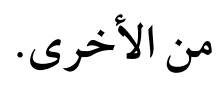

$$
\text { يجوز التعليل بعلتين إحداهما أكثر تعدياً من الأخرى. }
$$

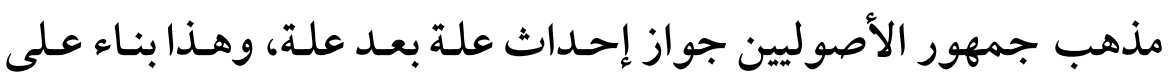

$$
\text { جواز تعليل الحكم الواحد بعلتين. }
$$

• الراجح: عدم جواز القياس على ماثبت بالقياس.

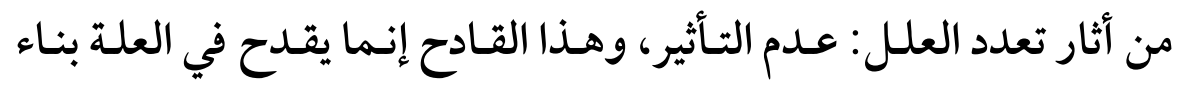
على أنَّ الحكم الواحد لا يجوز تعليله بعلتين، وأما إذا قلنـا بجرواز التعليل

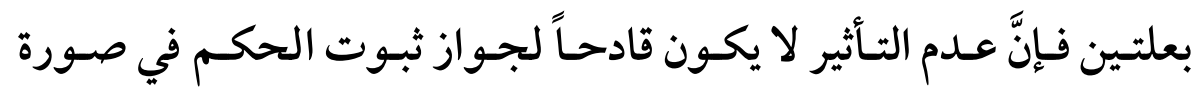

$$
\text { العلة، وثبوته في صورة أخرى لعلة أخرى. }
$$

اشـتر اط انتفـاء الوصفف المعـارض غير المنـافي للعلـة مبنى عـلى تعـدد

$$
\text { العلل. - (الم. }
$$

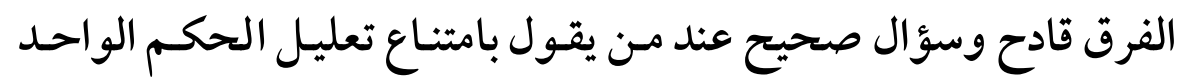

$$
\text { بعلتين فأكثر، ومن أجاز قال ليس بقادح في العلة. }
$$

• فساد الإلغاء بإبداء وصف آخر مبني على جواز تعدد العلل.

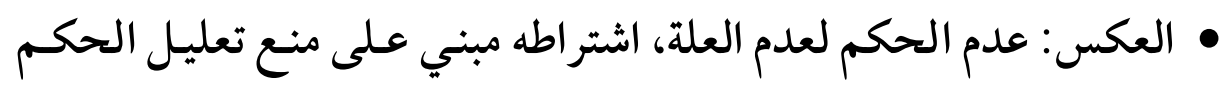

$$
\text { بعلتين: فمن منعه اشترطه؛ لعدم الحكم لعدم دليله. }
$$

الوصف الذي جعل ضابطاً لحكمته يجب أن يكون جامعاً للحكمة بنـاء

$$
\text { على جواز تعدد العلل. }
$$

من شروط العلة: أن تكون متحدة في الأصل عند من منع تعدد العلل. 
$(9 \vee \cdot)$

تعدد العلل وأثره عند الأصوليين "دراسة أصولية تطبيقية"

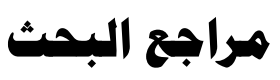

$$
\text { ا ـ القرآن الكريم }
$$

r. الإبهاج في شرح المنهاج لتقى الدين وتاج الدين السبكي ط: دار الكتب

العلمية -بيروت سنة 1990.

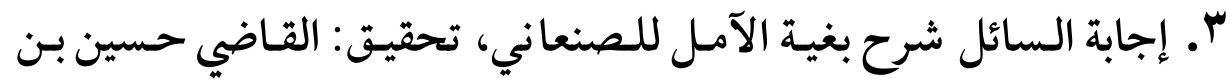

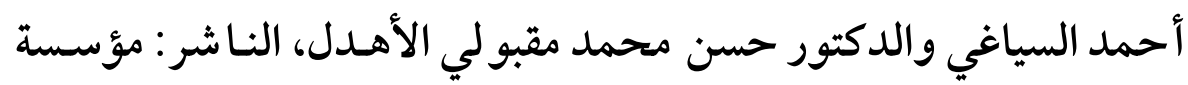

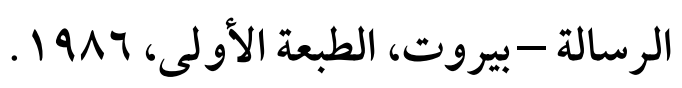

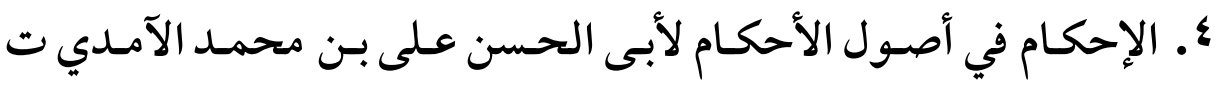

$$
\text { اسד هـ ط: المكتب الإسلامي -بيروت. }
$$

•. الإحكام في أصول الأحكام لأبى محمد بن حزم الأندلسي المتوفي سـنة

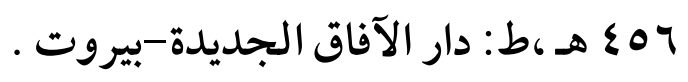

7. إرشـاد الفحـول إلى تحقيـق الحـق مـن علـم الأصسول لمحمـد بـن عـلى

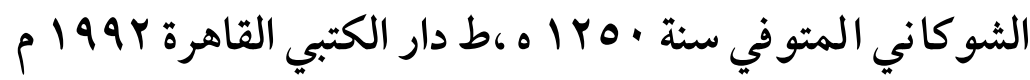

V. أصول السرخسي للإمام أبسى بكر محمـد بـن أحمـد السرخسي المتوفي

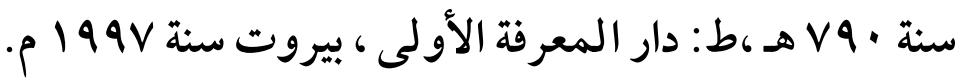

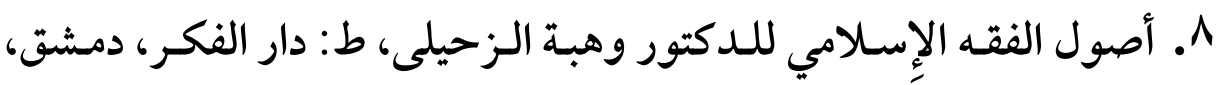

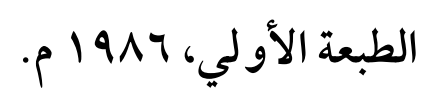

9. أصول الفقه الذي لا يسع الفقيه جهله للدكتور : عياض بـن نامى السلمي

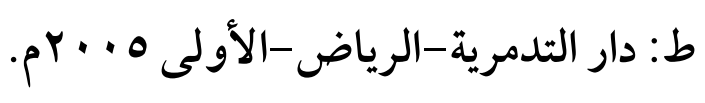


• 1. أصسول الفقـه للـشيخ عبـد الوهـاب خـلاف، النـاشر : مكتبـة الـدعوة-

1 1ا. أصول الفقه للشيخ محمد أبو النور زهير، النـاشر: المكتبـة الأزهريـة

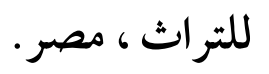

r أ. إعلام الموقعين عـن رب العـالمين لابـن القيم الجوزيـة شـمس الـدين

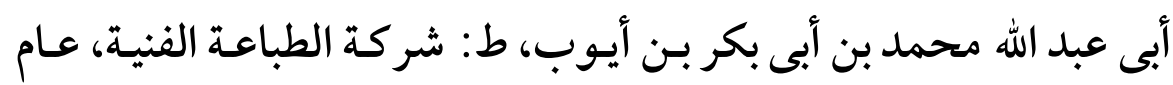

$$
\text { IrAN }
$$

با ا. الأعلام لخير الدين بن محمود بن محمد بن علي بـن فـارس، الزركلي الدمشقي ،المتوفي سنة: ج9 با هـ، الناشر: دار العلم للملايين الطبعـة:

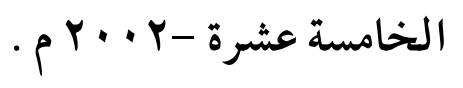

ـ اـ أنوار البروق في أنواع الفروق لشهاب الدين أحمد بن إدريس القرافي

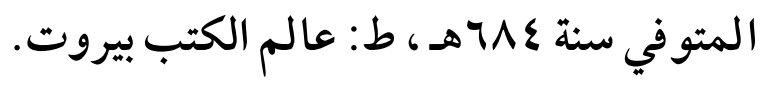

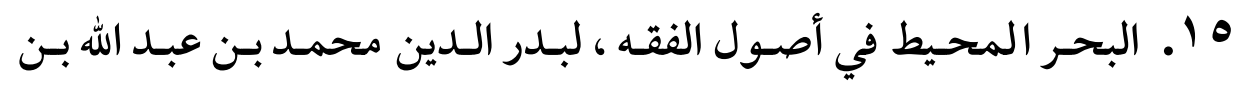

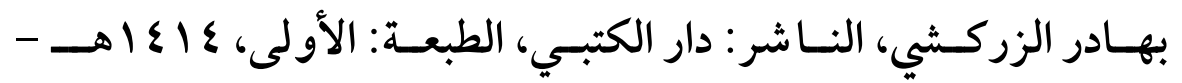

ا 1 ـ البرهان في أصول الفقه لعبد الملك بن عبـد الله بـن يوسف الجوينى ،

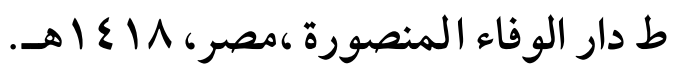

V V البلبـل في أصسول الفقـهـ لسليمان عبـد القـوي الطوفي، المتوفي سـنة

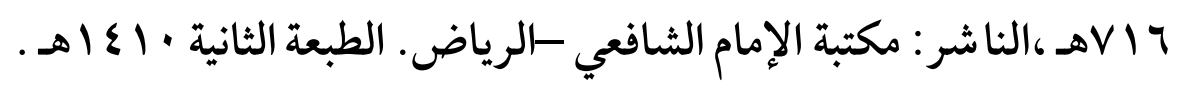




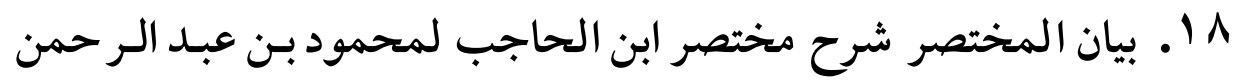

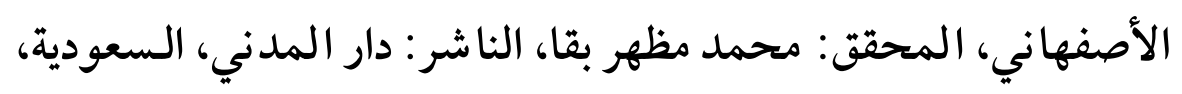

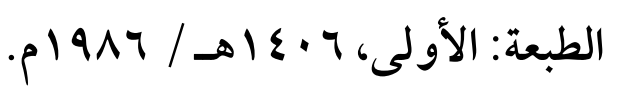

9 ا ـ التحبـير شرح التحريـر لعـلاء الــدين أبي الحسـن عـلي بـن سـليمان المرداوي الحنبلي، تحقيق د. عبد الرحمن الجبرين، د. عوض القرني،

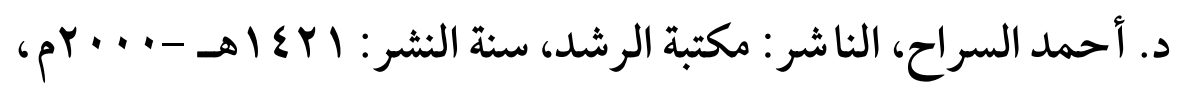

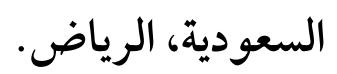

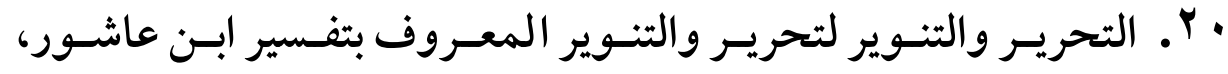

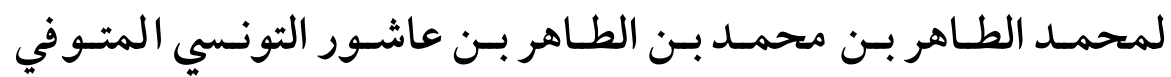
سنة سو با هـ، الناشر : مؤسسة التاريخ العربي، بيروت -لبنان، الطبعة:

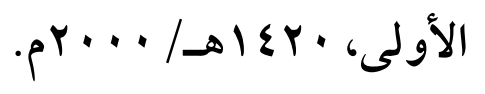

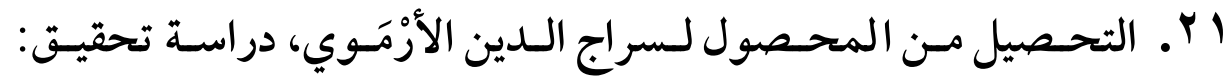
الدكتور عبد الحميد علي أبو زنيد، النـاشر : مؤسسة الرسـالة، بيروت -

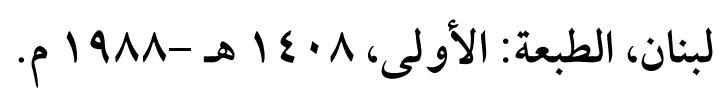
Y Y. تحفة المسؤول شرح مختصر منتهى السول ،لأبى زكريا يحيى بـن موسى الرهـوني، النـاشر : دار البحـوث للدراسـات الإسـلامية وإحيـاء

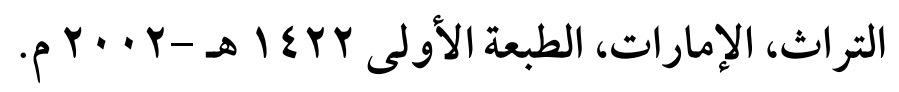

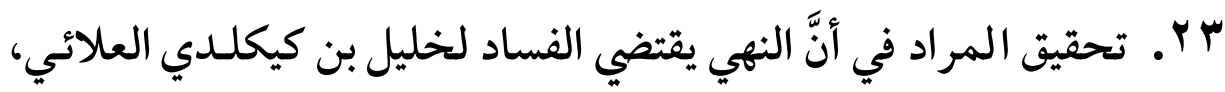

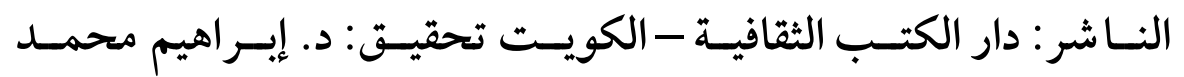


₹ r. التحقيق والبيان في شرح البرهان في أصول الفقه للأبياري، المحقق:

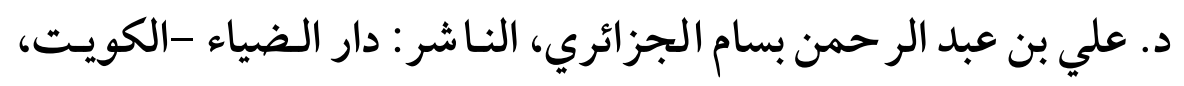

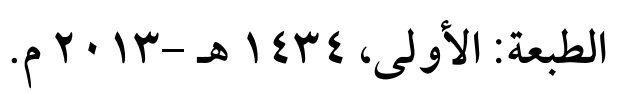

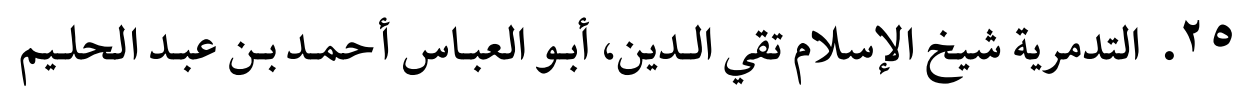

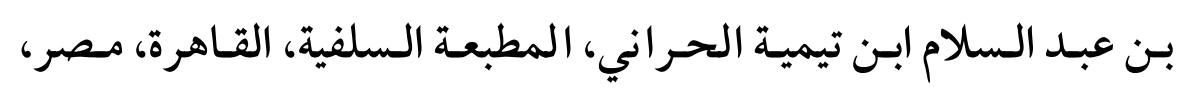

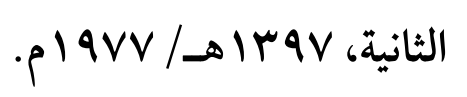

צ ا. تشنيف المسامع بجمع الجوامع لتاج الدين السبكي للزركشي، دراسـة

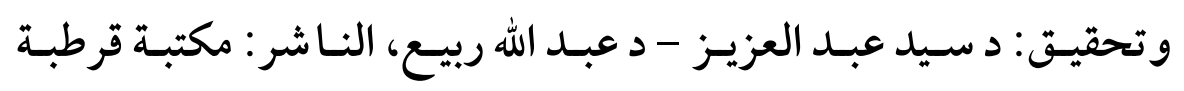

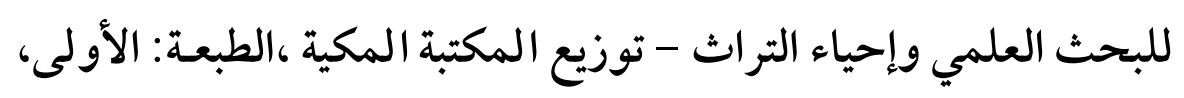

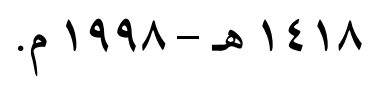

PV

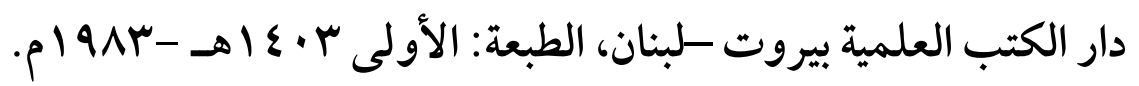

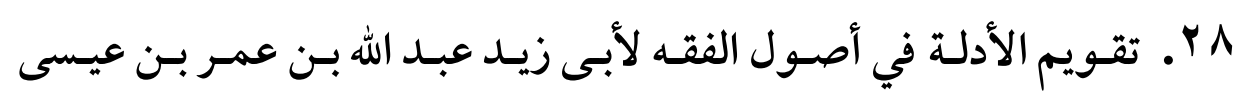

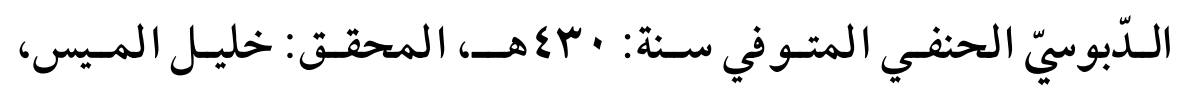

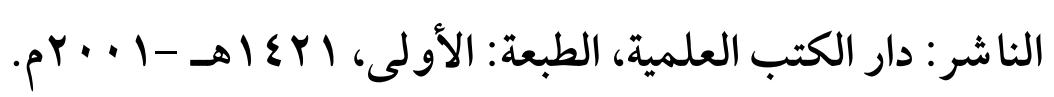

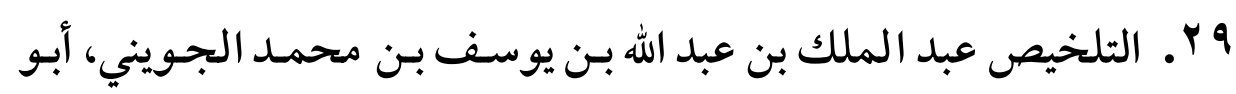

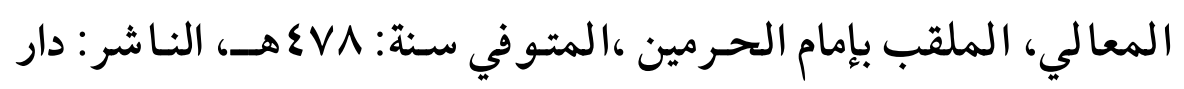

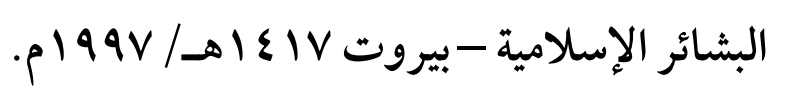

• r. التلويح على التوضيح لسعد الدين مسعود بن عمر التفتازاني المتوفي

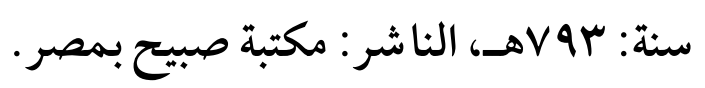




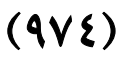

تعلد العلل وأثره عند الأصولييز "دراسة أصولية تطبيقية"

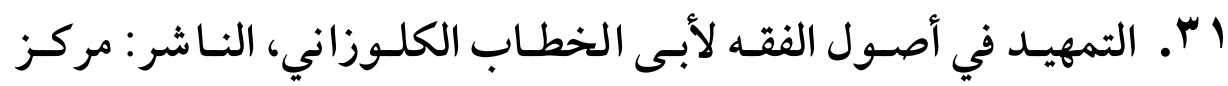

البحـث العلمـي وإحيـاء الـتراث الإسـلامي -جامعـة أم القــى، الطبعـة:

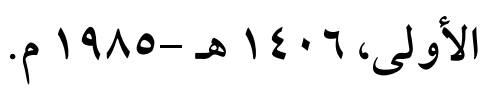

r r ت. تيسير التحرير لمحمد أمين المعروف بأمير بادشـاه، مطبعـة دار الفكر

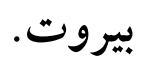

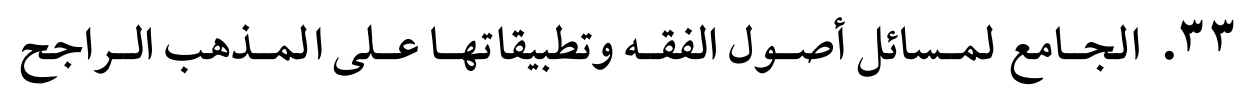
للدكتور عبد الكريم النملة، النـاشر : مكتبـة الرشـد -الريـاض -المملكـة

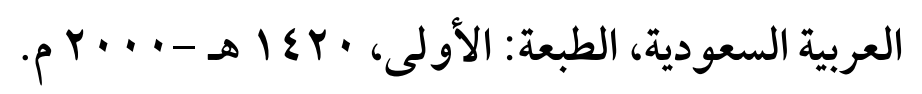

ع ". الجديد في الحكمة سعيد بن منصور بن كمونة، تحقيـق حميد مرعيد

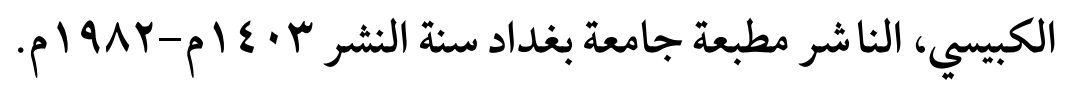
هّ". حاشية العطار على شرح الجلال المحلي على جمع الجوامع لحسن بن محمد بن محمود العطار الشافعي الناشر: دار الكتب العلمية. جَr. الخلاف اللفظي د. عبد الكريم بن على النملة، مكتبة الرشد-الريـاض،

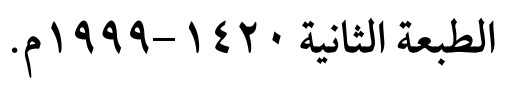
V V V. الدرر الكامنة في أعيان المائة الثامنة لابن حجر العسقلاني، ط: حيدر

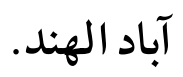
^ץ. الدرر اللوامع في شرح جمع الجوامع للكوراني، المحققى: سعيد بـن

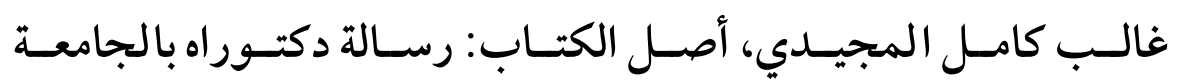

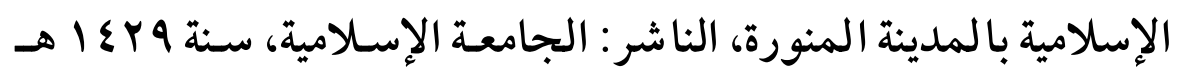




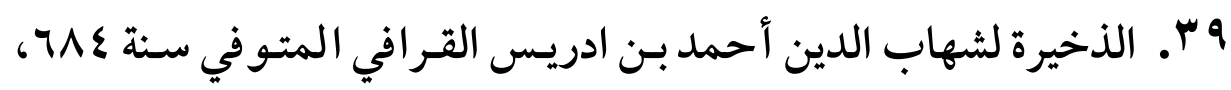

$$
\text { ط: دار الغرب-بيروت ع } 99 \text { ام. }
$$

• ؛. . رفع النقاب عن تنقيح الشهاب ، لأبي علي حسين بـن علي الرجراجي

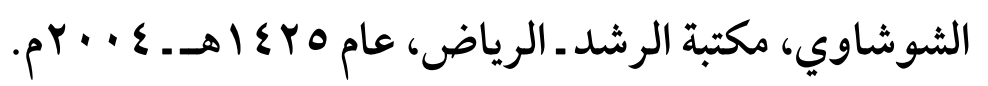

أـ. روضة الناظر وجنة المناظر لأبسى محمـد عبـد الله بـن أحمـد بـن قدامـة

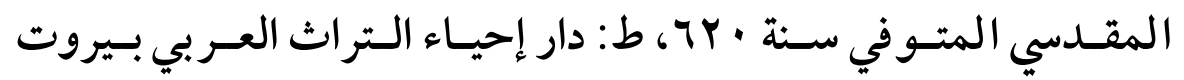

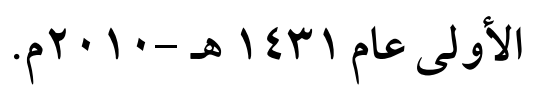

ץ భـ. السراج الوهاج على متن المنهاج للعلامـة محمـد الزهـري الغمـراوي،

$$
\text { الناشر: دار المعرفة للطباعة-بيروت. }
$$

r ع ـ سير أعلام النبلاء لشمس الدين أبو عبد الله محمد بن أحمد بـن عثمان

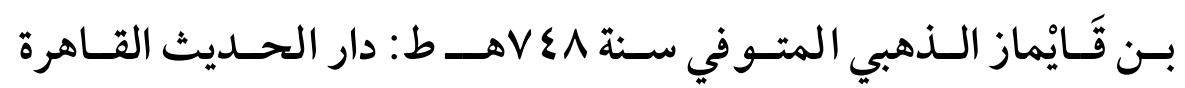

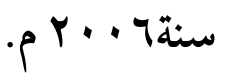

§ ؛ . شذرات الذهب في أخبار من ذهـب لعبـد الحي بـن أحمـد بـن محمـــ

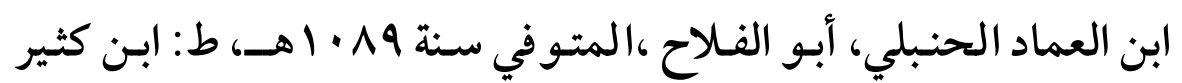

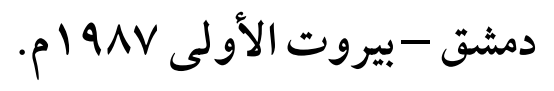

0 ؛ـ شرح العضد على مختصر ابن الحاجب، النـاشر: دار الكتب العلمية،

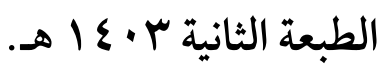

7 ؛ـ شرح الكوكب المنير لتقي الدين أبو البقـاء محمـد بـن أحمـد بـن عبـد

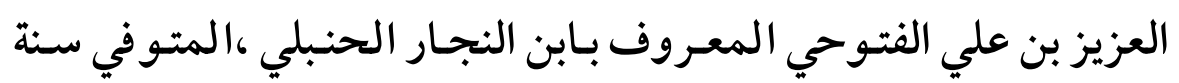


(9V7)

تعدد العلل وأثره عند الأصولييين "دراسة أصولية تطبيقية"

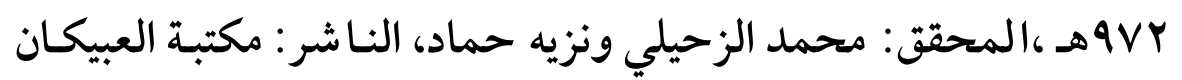

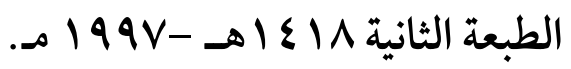

V V . شرح اللمع لأبى إسحاق إبراهيم بـن علي الشيرازي. ط: دار الغـرب

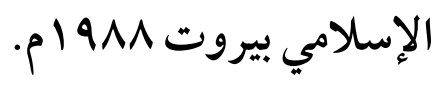

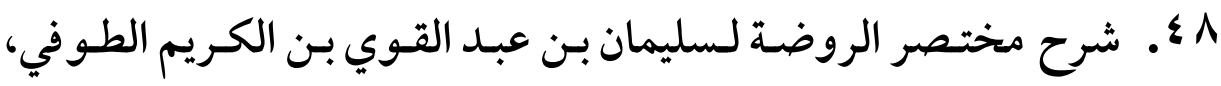

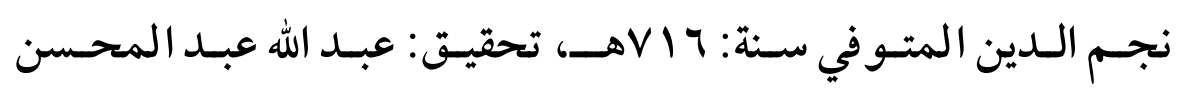

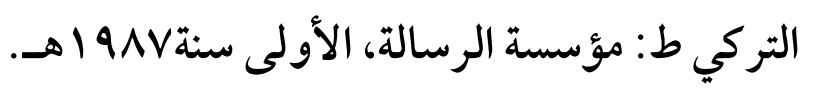

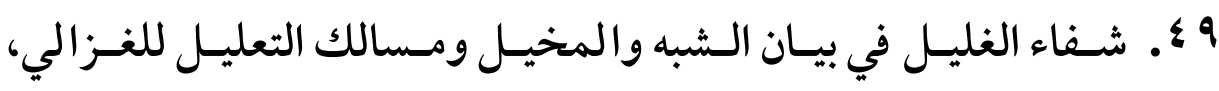

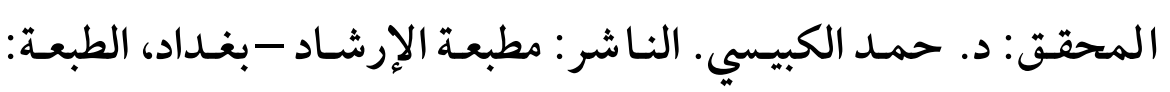

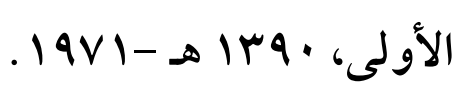

• •. صحيح مسلم للإمام مسلم بن الحجاج القشيري ط: دار إحياء التراث

$$
\text { العربي. }
$$

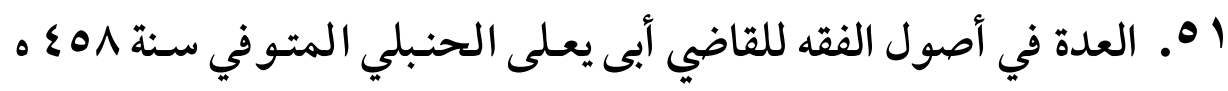

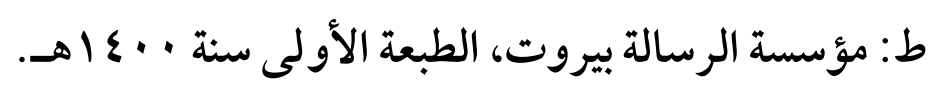

roه. العين لأبي عبـد الرحمن الخليـل بـن أحمـد الفراهيـدي النـاشر : دار

$$
\text { ومكتبة الهلال -تحقيق: د. مهدي المخزومي ود. إبراهيم السامرائي }
$$

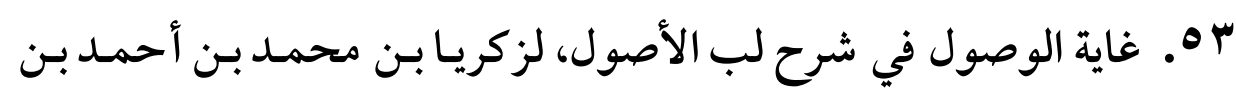

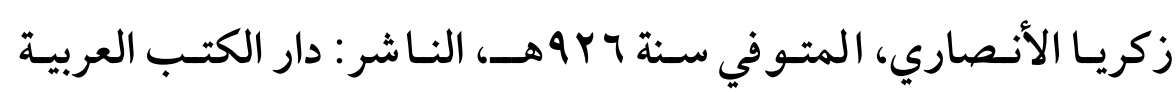

$$
\text { الكبرى، لمصطفي البابي الحلبي وأخويه بمصر. }
$$


ـ هـ الغيـث الهـامع شرح جمـع الجوامـع لأبي زرعـة العراقي، تحقيـق:

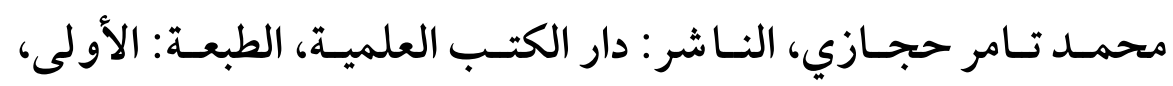

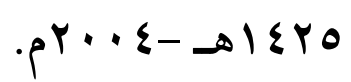

هـــ الفـائق في أصسول الفقـهـ لـصفي الــين الهنـدي الـشافعي، المحقـق:

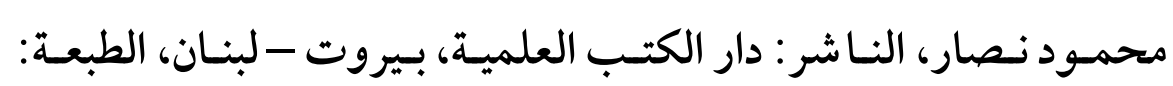

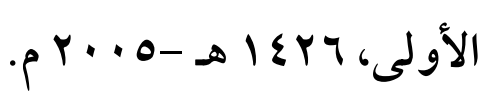

\ه ـ الفتح المبين في طبقات الأصوليين للشيخ عبد الله مصطفي المراغي،

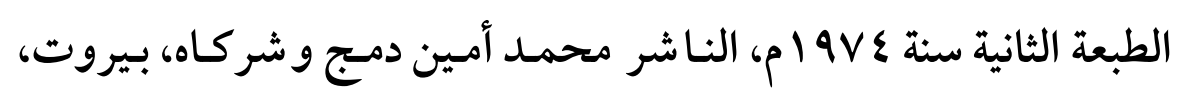
لبنان.

Vه. فصول البدائع في أصول الشرائع لمحمد بن حمزة الأنصاري الفناري ، المتوفي سنة ؟ ؟1 هـ، المحقق: محمد حسين إسـماعيل، الناشر : دار

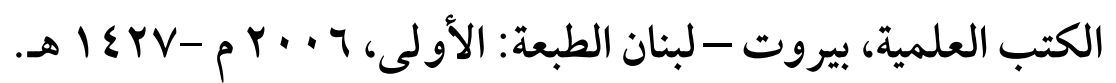
1ه. الفصول في الأصول للجصاص، المحقق: د. عجيل جاسـم النشمي،

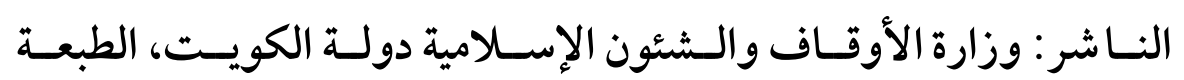

$$
\text { الأولى. }
$$

9هـ الفوائـد الـسنية في شرح الألفيـة ــ لمحمــــــن عبـد الــايم البرمـاوي المتوفي سنة اسبهــ ، تحقيق: عبـد الله رمضان، النـاشر : مكتبـة التوعيـة الإسلامية للتحقيق والنشر والبحـث العلمي، الجيزة - القـاهرة، الطبعـة

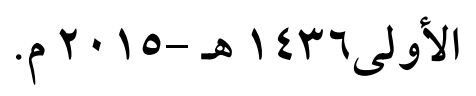


(9VA)

تعدد العلل وأثره عند الأصولييز "دراسة أصولية تطبيقية"

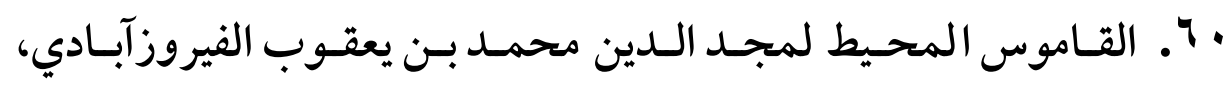

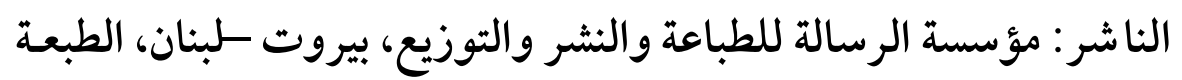

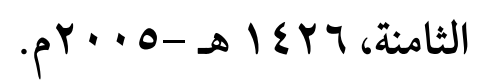

ال7. قواطع الأدلّة في الأصسول لأبس المظفـر منصور بـن محمـد السمعاني

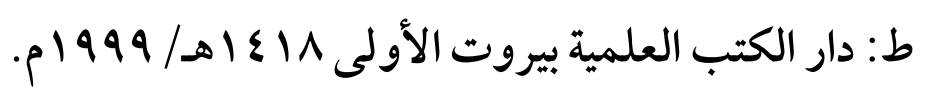

rآ. الكـافي شرح البزدوي للحسين بـن علي بـن حجـاج بـن علي، حسام

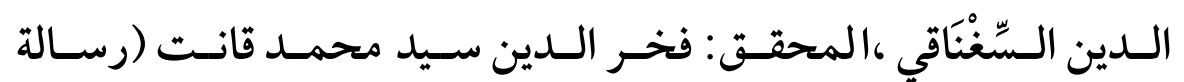

$$
\text { دكتوراه) الناشر : مكتبة الرشد-الرياض -للنشر والتوزيع. }
$$

با7. كشف الأسرار عـن أصسول فخـر الإسـلام البزدوي للإمـام عـلاء الـدين

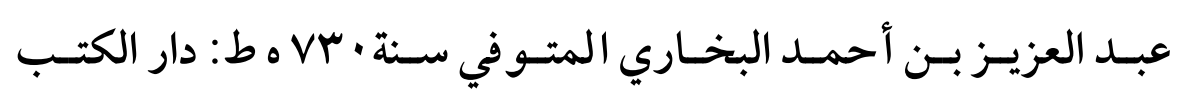

$$
\text { الإسلامي. }
$$

ء 7. لسان العرب لمحمد بن مكرم بن منظور الأفريقي المصري، الناشر:

$$
\text { دار صادر -بيروت، الطبعة الأولى. }
$$

هـ 7. مجموع الفتاوى لأحمد بن عبد الحليم ابن تيمية الحراني، المحققى:

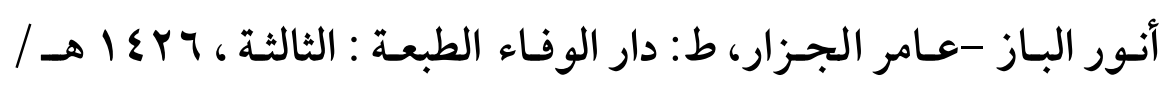

$$
\text { . } r \text {. o }
$$

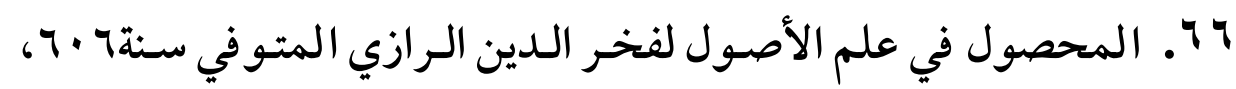
دراسة و تحقيق: الدكتور طه جابر فياض العلواني، ط: مؤسسة الرسالة

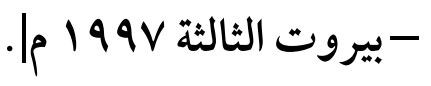


VIV. مختار الصحاح لمحمد بـن أبي بكر بـن عبد القـادر الرازي المتوفي

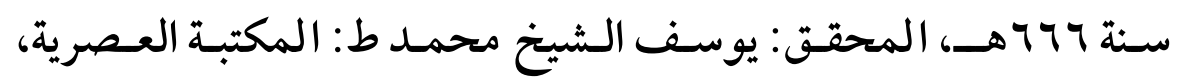

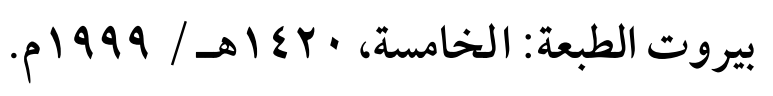

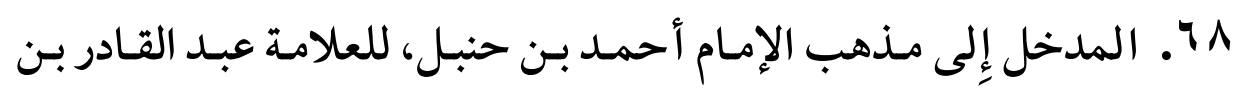

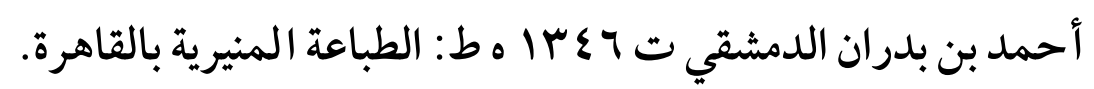

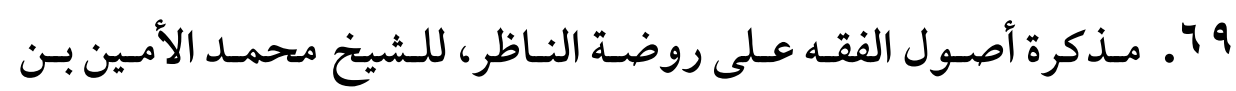
المختار الشنقيطي: دار القلم، بيروت .

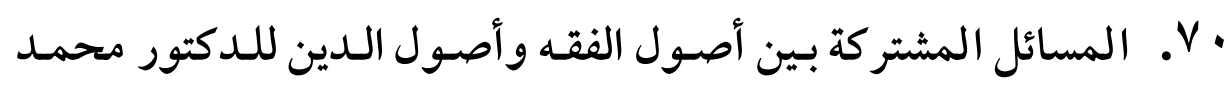

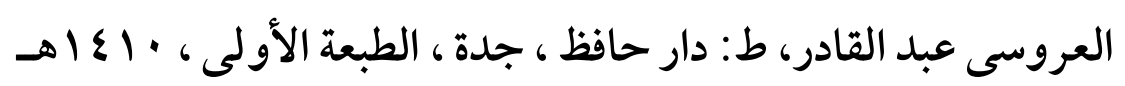

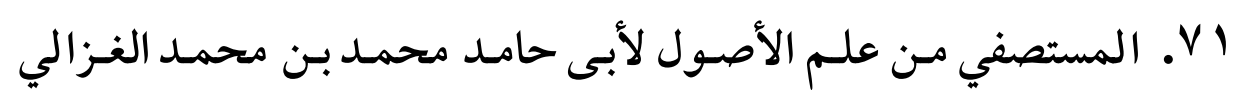

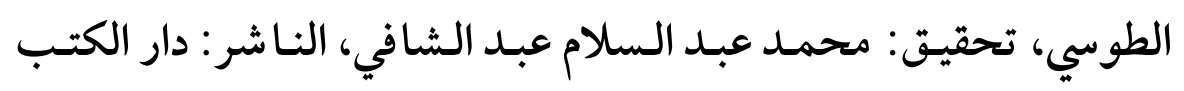

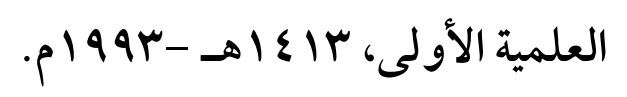

VY الفيومي ت · V Vه ط دار الفكر. VP

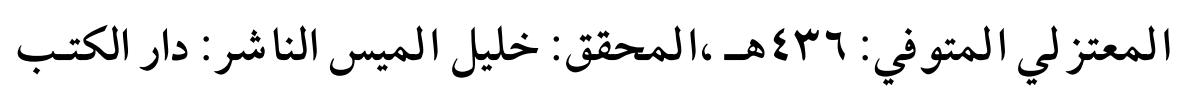
العلمية -بيروت، الطبعة الأولى. ع V. معجم المؤلفين لعمر رضا كحالة، ط: مكتبة المثنى -بيروت. 
$(9 \Lambda \cdot)$

تعدد العلل وأثره عند الأصولييين "دراسة أصولية تطبيقية"

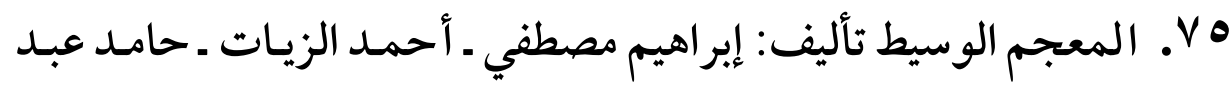

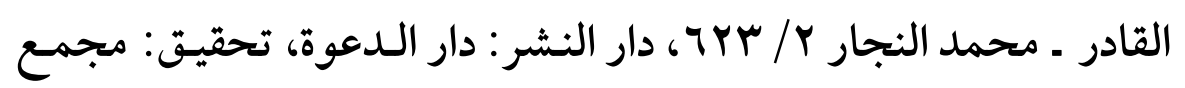

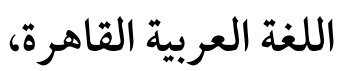

V V. المغنى لأبى محمد موفق الدين عبد الله بن أحمد بن محمـد بـن قدامـة

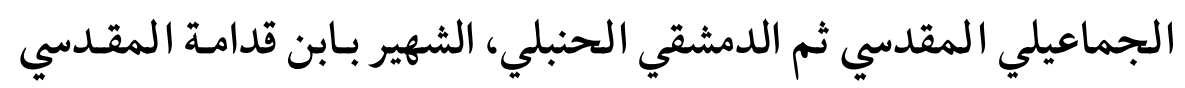

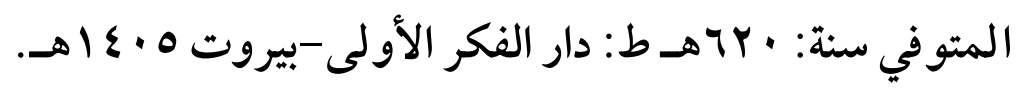
VV احمد المالكي التلمساني، المتوفي سنة VV Iهـ، توزيع مكتبة الرشاد.

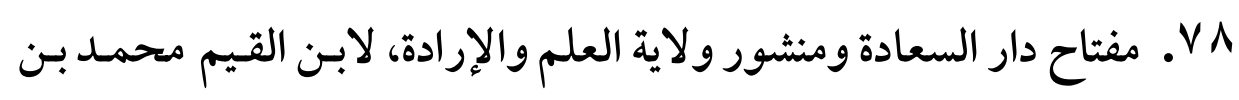
أبي بكر أيوب الزرعي أبو عبد الله، الناشر : دار الكتب العلمية - بيروت.

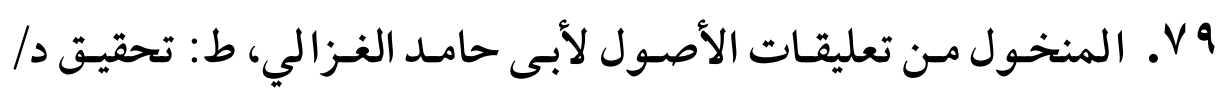
محمد حسن هيتو، طبعة دار الفكر دمشق سنة + . ـ ا هـ.

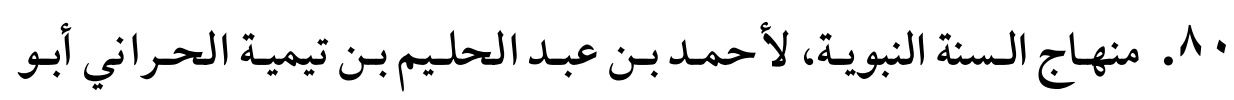

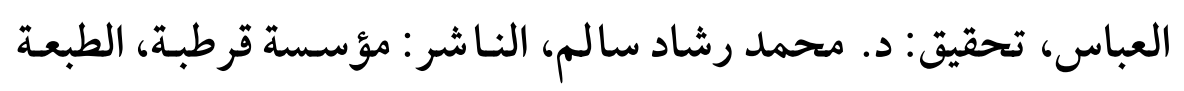

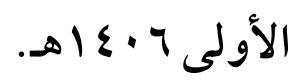

1 1. المهذب في علم أصول الفقه المقارن للدكتور عبد الكريم النملة ط: مكتبة الرشد -الرياض، الطبعة الأولى سنة 999 19 م.

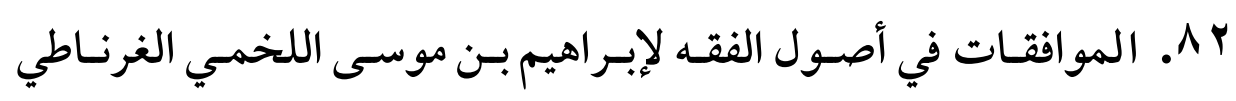

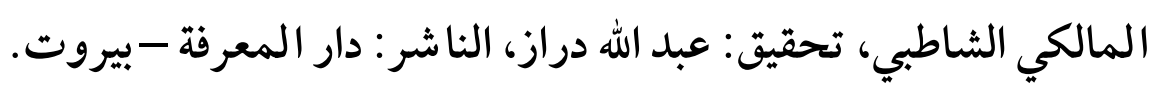


(911)

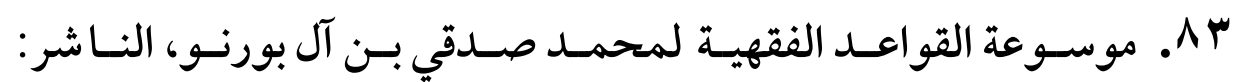

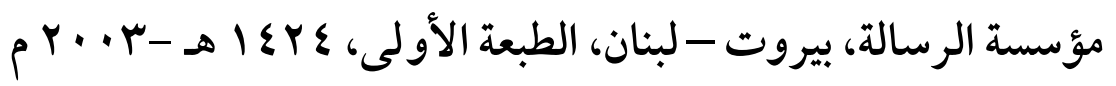

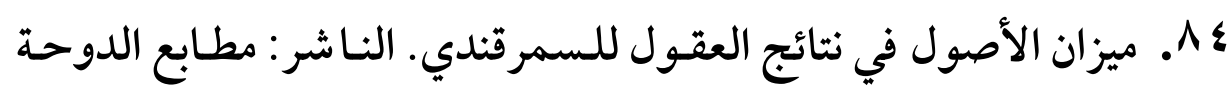

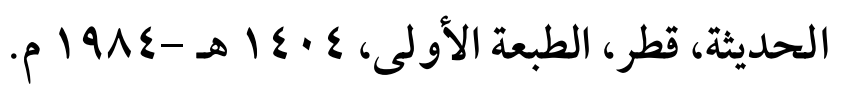

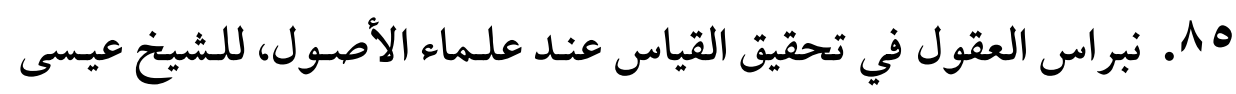
منون، مطبعة التضامن الأخوي - مصر، الطبعة الأولي.

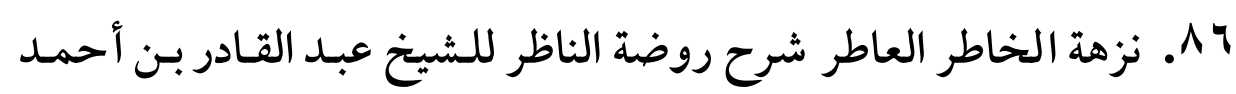

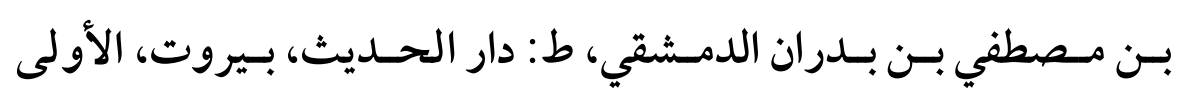
. $1991-1 \leqslant 1\}$

AV

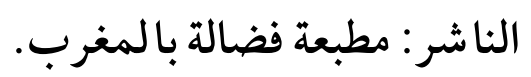

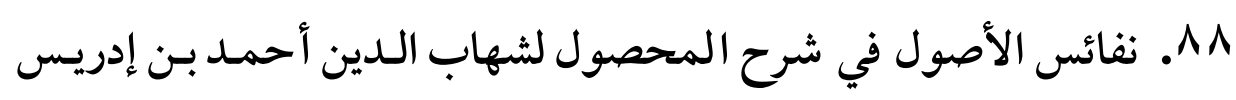

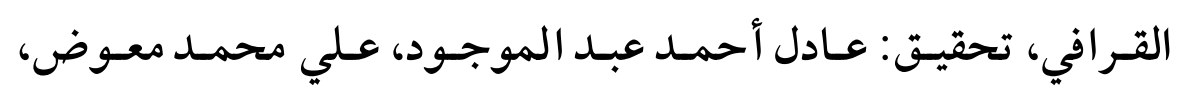

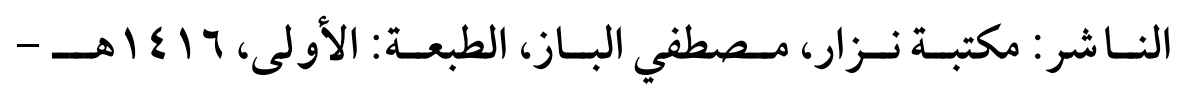
p 1990

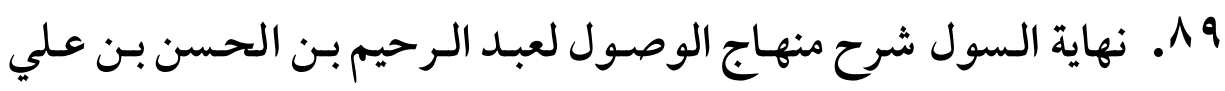

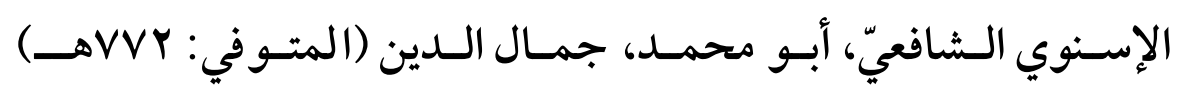

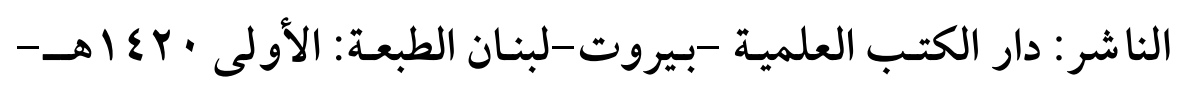


(qАY) تعلد العلل وأثره عند الأصولييز "دراسة أصولية تطبيقية"

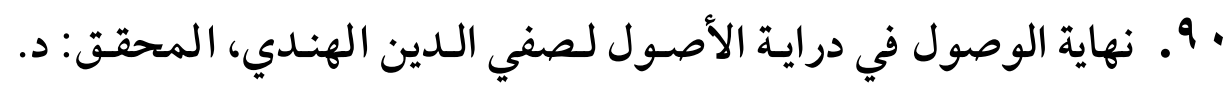
صالح بن سليمان اليوسف - د. سعد بـن سالم السويح ،أصل الكتاب: رسالتا دكتوراه بجامعة الإمام بالرياض ، الناشر : المكتبـة التجاريـة بمكـة

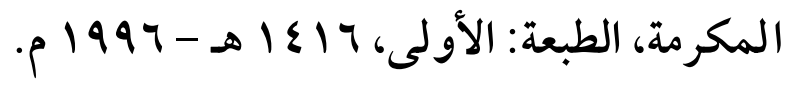

19. الواضـح في أصـول الفقـه لابـن عقيـل الحنبلي ط: مؤسـسة الرسـالة

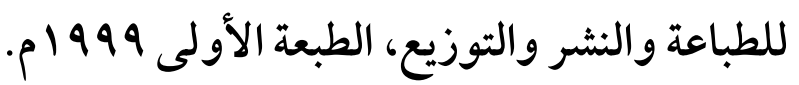

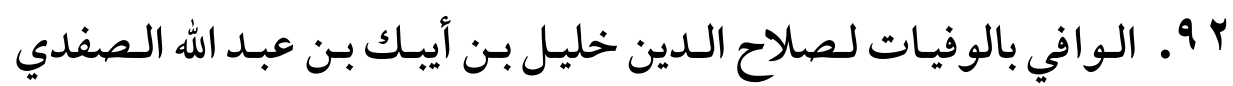

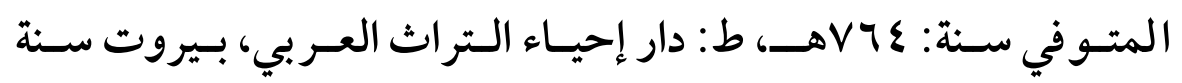


$(q \wedge \mu)$

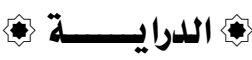

فهرس الموضوعات

\begin{tabular}{|c|c|c|}
\hline رقم الصفحة & الموضوع & $p$ \\
\hline AVT & ملخص البحث. & 1 \\
\hline AVA & المقدمة. & $r$ \\
\hline$\wedge \wedge \varepsilon$ & التمهيد : تعريف العلة لغة واصطلاحاً. & $r$ \\
\hline NQY & والمبحـث الأول: المـر اد بتعـدد العللـ، والفــق بينها & $\varepsilon$ \\
\hline N9Y & المطلب الأول :المر اد بتعدد العلل. & 0 \\
\hline$\wedge ৭ \wedge$ & المطلب الثاني: حكم التعليل بالعلة المركبة. & 7 \\
\hline$q \cdot r$ & مطالب: المبـــث الثـــي: حكــم تعــد العلـل، وفيـهـ أربعـة & $v$ \\
\hline $9 \cdot r$ & المطلب الأول :مذاهب العلماء في تعدد العلل . & $\wedge$ \\
\hline $9 \cdot 1$ & أدلة المذاهب ومناقشتها. & 9 \\
\hline $9 r$. & المذهب الراجح. & 1. \\
\hline $9 Y Y$ & نوع الخلاف في المسألة. & 11 \\
\hline $9 Y \varepsilon$ & 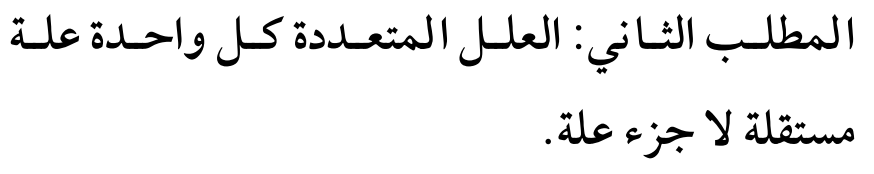 & Ir \\
\hline
\end{tabular}


$(9 \wedge \varepsilon)$

تعدد العلل وأثره عند الأصوليين "دراسة أصولية تطبيقية"

\begin{tabular}{|c|c|c|}
\hline QYT & المطلب الثالث: نوع الحكم الثابت بعلتين أو أكثر. & Ir \\
\hline arV & والمبحث الثالث: مـا ترتـب على جـواز تعـدد العلل، & $1 \varepsilon$ \\
\hline qrV & المسألة الأولى: تعليل الحكم بعلتين دلت إحـداهما & 10 \\
\hline $9 Y \wedge$ & المعلل بــألة الثانيـة: زوال إحســى العلتــين في الحكــم & 17 \\
\hline $9 \times 9$ & المسألة الثالثة: تعليـل الحكـم بعلتين إحـــاهما أعـم & IV \\
\hline 941 & فروعها أكثر من الأخرى. الرابعة: تعليل الحكم بعلتين إحـدى العلتين & 11 \\
\hline 941 & 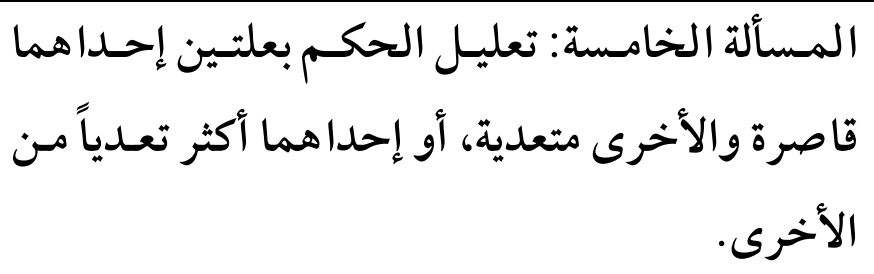 & 19 \\
\hline מתq & المسألة السادسة: الترجيح بكثرة العلل. & $r$. \\
\hline 940 & والمبحـث الثالـث: أثر تعـدد العلل عنــ الأصسولين، & YI \\
\hline qro & المطلب الأول: إحداث علة بعد علة. & $r Y$ \\
\hline 9 १૬. & المطلب الثاني: القياس على ما ثبت بالقياس. & r \\
\hline
\end{tabular}




\begin{tabular}{|c|c|c|}
\hline 0) & \multicolumn{2}{|c|}{ 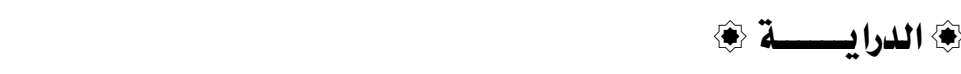 } \\
\hline $9 \leqslant \varepsilon$ & الثأثير) . & $r \varepsilon$ \\
\hline 901 & 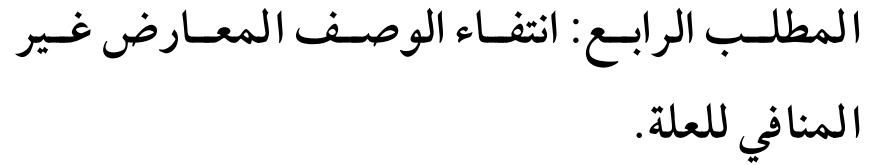 & ro \\
\hline 90$\}$ & لخـامس: الفـرق أو المعارضـة في الأصـل & ry \\
\hline $90 \mathrm{~V}$ & المطلب السادس: فساد الإلغاء أو تعدد الوضع . & YV \\
\hline 901 & 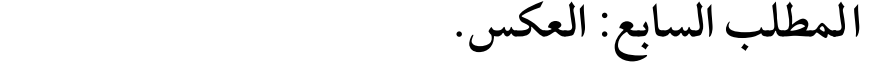 & $r \wedge$ \\
\hline 971 & المطلب الثامن: الوصف الذي جعل جعل ضابطاً لحكمته & rq \\
\hline 970 & 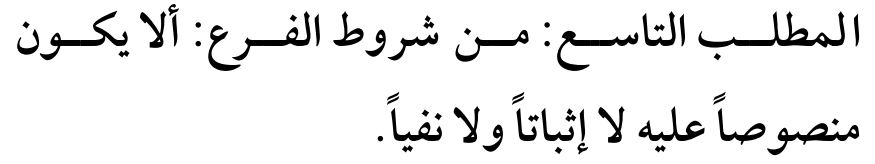 & $\mu$. \\
\hline $97 \mathrm{~V}$ & في الأصل. المطلب العر : من شروط العلـة: آن تكـون متحـدة & I \\
\hline 971 & 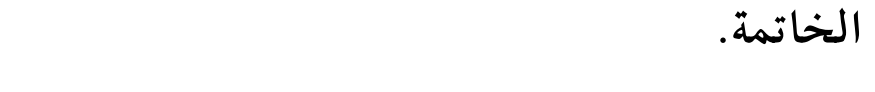 & rr \\
\hline $9 V$. & المر اجع وا لمصادر. & r \\
\hline$q \wedge \mu$ & 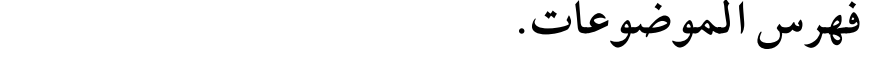 & r \\
\hline
\end{tabular}

